V.I. VERNADSKY TAURIDA NATIONAL UNIVERSITY

\title{
PSYCHOLOGICAL ACCOMPANIMENT OF PERSONALITY DEVELOPMENT
}

Collective monograph

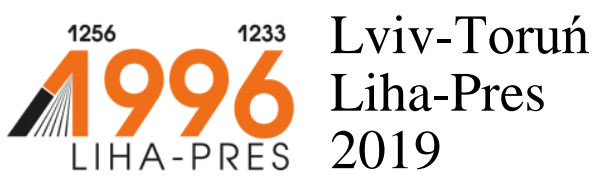




\section{Reviewers:}

Konrad Janowski, PhD, Vice-dean of the Faculty of Psychology, University of Economics and Human Sciences in Warsaw (Republic of Poland);

Prof. dr hab. Tadeusz Dmochowski, University of Gdansk (Republic of Poland).

Psychological accompaniment of personality development : collective monograph / S. P. Bielavin, T. I. Bielavina, I. N. Bila, N. A. Dobrovolska, etc. Lviv-Toruń : Liha-Pres, 2019. - 328 p.

ISBN 978-966-397-137-7

Liha-Pres is an international publishing house which belongs to the category "C" according to the classification of Research School for Socio-Economic and Natural Sciences of the Environment (SENSE) [isn: 3943, 1705, 1704, 1703, 1702, 1701; prefixMetCode: 978966397]. Official website - www.sense.nl.

An analysis of the studies presented in this collective monograph allows us to state that personality formation throughout the entire period of the historical development of mankind is an topical psychological and sociocultural problem.

The article deals with the personality capacities development in a modern educational system. In the work the authors reveal the ways, mechanisms and their effects in the formation of values of the student youth through the study of psychology using interactive teaching methods with the application of psychotechnologies. The development of gender-related training courses in work with young people are highlighted.

The actual problem of adult education is reflected, which highlights the issues of psychological accompaniment of adult students' educational activities. The publication reveals some aspects of the life of a person and a group of minors in penitentiary systems, which, to a certain extent, can act as a reduced model of a congruent society. The study also examines the socio-psychological problem of domestic violence against a child. 


\section{CONTENTS}

INTRODUCTION

HATE AS THE ULTIMATE FORM OF INTERGROUP CONFRONTATION

Bielavin S. P.

SOCIAL-PSYCHOLOGICAL ASPECTS OF INTRAGROUP ADJUSTMENT IN ADOLESCENTS PENITENTIARY SYSTEMS Bielavina T. I.

PSYCHOLOGICAL AND PEDAGOGICAL SUPPORT

FOR THE DEVELOPMENT OF CREATIVE CAPABILITIES IN THE CHILDHOOD PERIOD

Bila I. N.

PSYCHOLOGICAL AND PEDAGOGICAL ACCOMPANIMENT

OF A FOSTER FAMILY FOR FORMATION OF ORPHANED

CHILDREN'S FAMILY VALUES

Dobrovolska N. A .63

THE INFLUENCE OF SEDATIVE INDUCTOTHERAPY

ON APPETITE

Fedorych 0 . V. .84

PSYCHOLOGICAL ACCOMPANIMENT

OF THE STUDENTS' HEALTH RECREATION PROCESS

IN THE PSYCHOLOGICA FIELD

Kichuk A. V. .98

THEMATIZATION OF CULTURAL PRACTICES IN THE CONTEXT OF PSYCHOLOGICAL COMPENSATION Kopiyevska O. R.

BASIC STRUCTURE OF A GENDER-SPECIFIC TRAINING COURSE FOR WORKING WITH YOUNG PEOPLE (STUDENTS) Kostina T. O. 
THE POST-TRAUMATIC GROWTH AS THE FACTOR

OF PERSONAL DEVELOPMENT IN CONDITIONS

OF MODERN UKRAINE

Kostiuk O. I.

COGNITIVE POTENTIAL OF METAPHORIZATION

IN PERCEPTION OF "I-IMAGE"

Kostyuchenko O. V.

MANAGEMENT ABILITIES OF PERSONALITY CULTURE

MANAGER: THEORETICAL-EMPIRICAL ANALYSIS

Martynyshyn Ya. M.

PSYCHOLOGICAL ASPECTS OF ANDRONGO SUPPORT

Maslianikova I. V.

THE IMPACT OF DOMESTIC VIOLENCE ON THE

PERSONALITY'S DEVELOPMENT OF THE CHILD

Mitina S. V.

THE ISSUE OF THE RESEARCH OF CRIMEAN TATARS'

ETHNO-PSYCHOGENESIS AND ETHNIC AWARENESS

Osmanova A. M.

PERSONALITY VALUES' BECOMING IN EDUCATIONAL PROCESS: TECHNOLOGY AND EXPERIENCE

Romanyuk L. V. 281

PSYCHOLOGICAL AND PEDAGOGICAL IMPACT

ON THE DEVELOPMENT OF MODERN CHILDREN'S

CREATIVE ABILITIES

Vynohradova V. Ye. 300

CONCLUSIONS. .320 


\section{INTRODUCTION}

A changing society, where the processes of personalization, individualization and socialization of an individual, his formation and growth take place, is a fertile environment in which the subject reveals and realizes his own potential. Transformational processes cover all spheres of development of society as a whole, as well as the personality of each person who, in order to survive and adapt, must protect himself, preserve his own personal integrity, become capable of self-realization on the basis of creative perception of civilizational changes, effective self-regulation of one's own states, motives, needs, behavior, formed skill and desire to learn and improve throughout life. Social processes and phenomena cannot be fully disclosed without attracting knowledge about the mechanisms of people's individual and group behavior, without studying the psychological properties and peculiarities of an individual, his abilities, motives, character, and the like. In other words, in the study of social processes there arises a need to take into account psychological factors.

The collective monograph is the result of research work by representatives of the scientific and pedagogical staff of various educational institutions, which discloses a wide range of theoretical, methodological and applied problems related to the creation of an educational and cultural environment as such a totality of conditions for learning, development, individualization and socialization of a person of different age, gender, status and ethnic categories, in accordance with its natural inclinations, interests and social requirements. With a foundation of the achievements of various areas of psychological science and related disciplines, the authors tried to achieve an integrative interpretation of various categories of personality issues, to highlight the urgent issue of determining and identifying the socio-psychological, organizational, ethnic and cultural foundations, factors, conditions and factors of effective learning, establishment and development of a holistic personality.

The main idea of the presented work is that for the organization of daily life, the development of personal and professional self-realization, actualization, the ability to solve creative problems, the formation of a person's life position, it is necessary to develop and implement a holistic system of psychologically, pedagogically and culturally oriented projects, taking into account the psychological aspects of cultural, ethnic, gender, 
social, moral, ethical, organizational, managerial issues, namely: the phenomenological approach to the to the formation of an individual's values in his or her search activity; psychologically compensatory component of cultural practices; ethnopsychogenesis and ethnic consciousness; androgynous accompaniment of educational services for an adult; peculiarities of the formation, disclosure and development of the personality's components, in particular, his self-awareness and self-esteem, managerial abilities; issues of post-traumatic growth as an effective mechanism of personality development; the results of the analysis of effective means of diagnostics and activation of children's creative abilities, construction of an integrative theoretical and structural model of their development; sustainability of the pedagogical and psychological impact in the development of creative abilities of the youth; phenomena of social perception and interaction, leading to conflict situations; the specifics of certain manifestations of group establishment and group structure; overcoming and preventing any manifestations of violence against children, ensuring the proper children's well-being and education and the like. The realization of this idea is a necessary step for understanding the directions and tendencies in the effective realization and development of the individual in the cognitive, affective, personal, social and socio-cultural sphere.

The efforts of the authors are addressed to scientists and practitioners in the field of general, social, gender, age, ethnic psychology, personality psychology, management psychology and related disciplines, as well as teachers, graduate students and students of psychological specialties. The team of authors hopes that the book will find its reader.

The team of authors is sincerely grateful to the leadership of Tavrida National V.I. Vernadsky University, in particular, the director of the Educational and Scientific Humanitarian Institute, Candidate of Juridical Sciences, Associate Professor Ilyashko Oleksandr Oleksandrovych for the idea of creating this monograph and promoting its publication. 


\section{HATE AS THE ULTIMATE FORM OF INTERGROUP CONFRONTATION}

\section{Bielavin S. P.}

\section{INTRODUCTION}

Number of interrelated crises that occur simultaneously worldwide show global and systemic world processes. The crisis of civilizational choices, the cultural crisis, rising levels of social and economic inequality, rising levels of social tension, aggression, and violence all lead to a social inquiry to uncover the essence of social perceptions such as hatred.

Psychology has long "shied away" from the study of a phenomenon so important to the life of every person and society as a whole. Until recently, the topic of negative attitudes and attitudes in psychology was limited to studies of anger, hostility and aggression, as well as studies of social discrimination and prejudice.

According to G. Allport, prejudices are so constant, despite the large amount of information that contradicts them, precisely because of the emotional component. Most likely, hatred forms the emotional basis of most human prejudices and prejudices ${ }^{1}$.

Since 2001, the US (Gonzaga University) has published an interdisciplinary journal of hate studies. In 2005. the first collection of articles on hate psychology was published. And in 2008, the first symposium on the psychology of love and hate was held at Tartu at the 14th European Conference on Personality Psychology.

The rather poor development of phenomenology and hate issues is obviously linked to a certain taboo of discussing this topic in society, as well as to a number of moral, ethical and organizational problems associated with research. For example, in group studies, group members usually not only overestimate the own and other group, but also deny the presence of socially disapproving feelings for "others".

In scientific sources, many terms are used to describe "alien": "stranger", "enemy", "marginal", "monster", etc. Analytically, the differences between them are indistinguishable, which makes it possible to

\footnotetext{
${ }^{1}$ Allport G.W. The nature of prejudice. Garden City, NY: Doubleday Anchor Books, 1958.
} 
apply the general concept of "alien" to an ethnic group that is subject to discriminatory practices that have real consequences for an "alien" ethnic group in the form of manifestations of interethnic intolerance. To give at least some legitimacy to these manifestations of intolerance, ethnic groups are transformed into "alien" by the significant role of norms and values that dominate society, and to some extent make the phenomenon of ethnic intolerance for society, so to speak, "invisible",

\section{Hate as a social-psychological category}

At the moment, there is little research in psychology on a chosen topic, which may be because there is no commonly accepted definition of hatred. Some researchers suggest that hate is an emotion caused by situational factors, and a number of other psychologists believe that hate is a personality trait that has been stable for a long period of time.

Aristotle defined hate by comparing it to anger. The philosopher believed that hatred can occur even without a previous crime and can be targeted at different groups. However, anger can only be directed at individuals. In addition, anger arises from pain while hatred can be no painful for the enemy.

In contrast, in the seventeenth century, the Dutch rationalist philosopher Benedict Spinoza wrote: "Love is nothing but pleasure (joy) accompanied by the idea of an external cause, and hatred is nothing but dissatisfaction (sadness) accompanied by the idea of an external cause. Further, we see that the one who loves must strive to have a favorite object of existence and keep it; and vice versa - the one who hates, seeks to remove and destroy the object of his hatred"3.

Modern ideas of hatred also differ in content. Some researchers defined ayut hatred as intense and irrational emotion, impairment of perception, because it is misleading and requires thought objects, which can be attached. Others believe that hate is not always irrational. If the enemy seeks ... to destroy you, your loved ones, or your country, hatred can be an adaptive and rational response that helps to survive. That is, modern scientific thought determines the ambivalent essence of the delineated feeling: on the one hand, irrationality, and on the other rationality and the need to experience hatred.

\footnotetext{
${ }^{2}$ Чужой [Электронный ресурс]. - Режим доступа : http://ecdejavu.ru/c/Chuzoy.html.

${ }^{3}$ Спиноза Б. Избр. произв.: В 2 т. Т. 1. М: Политиздат, 1957. С. 467-468.
} 
Kimberly Dozier suggested that hatred evolves from the ancient survival instinct. It includes intense at once, anger and stereotypes. In this sense, hate in an aggressive form is a hostility that reflects the extreme form of fear. However, when experiencing hatred, the individual's reaction is to fight, not run, to flee, as is usually the case with fear. The researcher notes that hatred is a kind of hypertrophied anger, fear; an experience that in the past has helped mankind to prevent dangerous situations, but today is somewhat outdated for the public order. Thus, hatred is a disorder that disrupts social functioning in today's world ${ }^{4}$.

A. Kernberg believes that hatred is not necessarily a pathological manifestation. When it appears in response to real and objective dangers, it is a normal form of anger aimed at eliminating the threatening object. In addition, feelings of hatred are often altered and heightened by other, more unconscious, emotions, such as a thirst for revenge. Thus, hate is a complex aggressive affect that is chronic and stable, unlike rage or anger. Its main purpose is to destroy the object of hatred ${ }^{5}$.

Paul Ekman described hatred as emotionally colored relationships like love. Love and hate are more resilient than other feelings, but they have a complex structure that involves a lot of emotions ${ }^{6}$.

According to R. Sternberg, hatred potentially consists of three components: denial of closeness, passion and obligation. The denial of closeness is that hatred of someone is disgusting. Passion expresses itself as intense anger or fear in response to a threat. The obligation is characterized by a deterioration in the perception and devaluation of the hateful group or object based on contempt. These three components lead to seven different types of hatred, depending on certain combinations ${ }^{7}$.

Typically, the subject perceived hatred that hate as social exceed enyy (asymmetry of power) entity (individual or group) that makes violence against others ${ }^{8,9}$. The notion of power asymmetry implies that hatred does not have effective protection against the object of hatred and against

\footnotetext{
${ }^{4}$ Kimberly Dozier Breathing the Fire: Fighting to Survive, and Get Back to the Fight.

${ }^{5}$ Кернберг О. Отношения любви: норма и патология / О. Кернберг. Пер. с англ. М.Н. Георгиевой М.: Независимая фирма «Класс», 2000. - 256 с. - (Библиотека психологии и психотерапии, вып. 76).

6 Экман, Пол. Психология эмоций / пер. с англ. В. Кузин. - СПб.: Питер, 2010. - 336 с.

${ }^{7}$ Sternberg R.J. (ed.). The psychology of hate. Washington, DC: APA, 2005.

${ }^{8}$ Fitness J. Anger in the workplace: An emotion script approach to anger episodes between workers and their superiors, co-workers and subordinates // J. of Organizational Psychol. 2000. V. 21. P. 147-162.

${ }^{9}$ McKellar P. Provocation to anger and development of attitudes of hostility // Brit. J. Psychol. 1950. V. 40. P. 104-114.
} 
humiliation, physical pain, or the threat to the well-being and values that flow from it.

It must be emphasized that in order to develop hatred, violence and / or threats that come from hatred must be continuous or repeated. A one-off attack only causes anger or other fleeting emotion. Only repeated attacks or conflicts can be decisive in developing hatred for a particular person or group $^{10}$.

D. Bar-Tal believes that victims of violence are more likely to be hateful than abusers, but in prolonged conflicts both sides consider themselves victims of violence ${ }^{11}$.

G. Breslav modified R. Sternberg's model, reducing it to two-factor: passive hatred (fear, avoidance, distance) and active hatred (condemnation, anger, desire to punish $)^{12}$.

Hate is seen in linguistics as a discursive practice. SA Kolosov brought out the following manipulative strategies of hate discourse: metaphorical forms of nomination of We and They of groups, stereotyping of discourse, strategy of finding the "go-go", narrowing or expanding the semantic meanings of words-concepts, ignoring facts and objective data, changing the source speaking, using vocabulary with implicit argumentative meaning. It also identifies two major functions of these strategies: 1) the discursive construction of hatred (by updating the metasense of "hatred"); 2) the legalization (normalization) of hatred".

The quality and concept of hate semantics, ways of its linguistic realization, binary oppositions of love / hate in different linguistic cultures are analyzed.

Neuroscience attempts to identify neurological markers of hatred. S. Zeki and J. P. Romaya ${ }^{14}$ conducted an experiment by demonstrating a photo of people hated by them and scanning their brains with a functional magnetic resonance imaging scanner. The results revealed a unique

\footnotetext{
${ }^{10}$ Baumeister R.F., Butz D.A. Roots of hate, violence, and evil // Sternberg R.J. (ed.). The psychology of hate. Washington, DC: APA, 2005. P. 87-102.

11 Bar-Tal D. Collective memory of physical violence: Its contributions to the culture of violence // G. Salomon, B. Nevo (eds). Peace education: The concept, principles and practice around the world. Mahwah, NJ: Lawrence Erlbaum Associates, 2002, P. 27-36.

${ }^{12}$ Breslavs G., Tyumeneva J. Toward operationalization of the hate concept: Is hate an opposite to love? // The paper presented at the 14th European conference on Personality, Tartu, July 16-20, 2008.

13 Колосов С.А. Манипулятивные стратегии дискурса ненависти / С.А. Колосов // Критика и семиотика. - Вып. 7. - Новосибирск, 2004. - С. 248-256.

${ }^{14}$ Semir Zeki, John Paul Romaya. Neural Correlates of Hate / Plos One. https://journals.plos.org/plosone/ article?id=10.1371/journal.pone.0003556
} 
neurological pattern of activity. The results showed that hate activates aggression-related brain regions and areas responsible for preparing the body for movement that translate aggression into action.

It turns out that hatred also activates the other two brain regions, the shell and the islet lobe associated with passion, romantic love. Hatred also partially activates both the cerebral cortex and subcortical areas, in particular, the premotor cortex, which is involved in the planning of actions and their execution.

So, summing up the variety of definitions, taking into account contemporary views, let us try to determine that hatred is a persistent negative feeling of the subject directed at another person, group of people, inanimate object or phenomenon, which poses a real or perceived threat to the needs, beliefs or values object. This feeling is characterized by the constant desire of the subject to inflict as much pain or suffering (up to the destruction) of the object of hatred, real or imagined, as possible.

\section{The place and role of the hated category in the system of conflictogenic social categories \\ 2.1 "Own-stranger" as a predictor of hatred}

Renowned psychologist P. M. Shyhiryev believes that the prospects of social psychology, associated with the study of the interaction of the individual and society as a body, to be performed at the level of reality that is conditioned by human values. They give meaning to the existence and behavior of a person in his interaction with other people, the world and himself. He understands social interaction as a connection of social actors (individual and collective), which is psychologically realized in relation to themselves, to each other and to reality ${ }^{15}$.

Mr. M. Shyhiryev notes that signs of social interactions unfold in the exchange system and subject - to - subject and subject - to - object interactions and attitudes. He defines the subject of social psychology "as a study of attitudes (appraisals) to relationships (connections)." $\mathrm{He}$ emphasizes the need to study the processes of the emergence, functioning and dying away of forms of objectification of value attitudes in social exchange, in real life.

\footnotetext{
15 Шихирев П.Н. Современная социальная психология / П.Н. Шихирев. - М. : ИП РАН, КСП+, Академический Проект, 1999. - 447 с.
} 
One of the phenomena of social perception that directly related to categories hatred opposition is "own-stranger." It represents one of the fundamental oppositions in the scientific picture of the world in, the basic way of categorizing social being, the separation of the world perceived as "one's own", close, safe, from the world, evaluated as "alien", unknown, dangerous, the way of organizing social reality, which is subordinated to other types of social actions and human relationships ${ }^{16}$.

In the general philosophical, cultural, social and psychological context, the category "own - stranger" reflects one of the basic oppositions that arose and developed from the period of pre-scientific knowledge about the world, about oneself, about others, which causes the separation in the general picture of the world that is perceived by the individual and the group in general as "his" (understandable, not threatening physical existence and mental well-being) from another conception of "alien" environment: unfamiliar, incomprehensible, and therefore allegedly necessarily threatening to person, for reference group, community. Moreover, from the perspective of social psychology concept of "own stranger" is defined and understood as opposed to "we - they" and the division into "us" and "them"

The oposition of "own - stranger" is the most certain value ratio, which serves as a social orientation. Such a contradiction is the basis of the paradox of the perception of the "other".

The concept of "own - stranger" is used in the theories of intercultural communication, in cross-cultural studies, which defines the concept of ethnos as a group of people who have similar knowledge about life, but the forms of its storage and transmission to the next generations are different, which makes it possible to be aware of each other as "strangers", that is,"not like ones".

In social psychology, the opposition of "own - stranger" underlies the analysis of the features of interpersonal and intergroup perception, in particular in the sphere of communication of national identity and language.

In the sociological aspect, opposition "own - stranger" is explored as a manifestation of the internal differentiation of society, which defines the relationships between individual social groups.

\footnotetext{
${ }^{16}$ Белинская Е.П., Тихомандрицкая О.А. Социальная психология личности : учеб. пособ. для вузов / Е.П. Белинская, О.А. Тихомандрицкая. - М. : Аспект Пресс, 2001. - 301 с.

${ }^{17}$ Гумилев Л.Н. Этногенез и биосфера Земли / Л. Н. Гумилев. - СПб. : Ленинградское Изд-во, 2011. 560 c. - C. $25-27,92-96$.
} 
The ability to divide into "own - a stranger" is given to the person because he or she is necessary for its development. As early as childhood, the child begins to differentiate himself from the outside world, such as "I" from "not - I", "his - not his" body. In order to learn how to control one's body, a child must first understand where its boundaries are. When it becomes clear with the limits of one's own body, the child switches to others, setting the boundaries of "own - stranger" emotional space, especially with those who are near the moment of birth. Therefore, a very important achievement in the child's mental development is the so-called emotional separation from the parents.

Separating their feelings and desires from others, a person gradually clarifies their emotional boundaries. That is, it learns to perceive itself as an independent person, capable of making decisions and be responsible for them. In adolescence, the definition begins with the worldview, with ideology, etc., but usually it comes down to associations of interests.

In the Ufa laboratory of high-tech psychology, a group of scientists has proposed a quadrupole model of the structure of the "own - stranger" archetype, which, in the authors' opinion, opens up new possibilities for emergency diagnostics and management of deep social behavior. Researchers G. A. Aminyev, E. G. Aminyev, M. N. Ivanov, and considered the archetype of "own - stranger" as a psychological formation that includes four individually-typological variations depending on the direction and tropism antitropism to "theirs" and "strangers", namely: tropism to "theirs" by positive qualities; antitropism to "strangers" by negative qualities; a complex of marked tropism to "one's own", which is combined with antitropism to "alien" (that is, it is an intolerant attitude towards "alien"); various paradoxical attitudes (tropism to "strangers" and antitropism to "one's own", or disorganization of the archetype, such as "Stockholm Syndrome"); antitropism to both "theirs" and "strangers" (alienation) $^{18,19}$.

To some extent, the problem of the "one - stranger" dichotomy is also reflected in the linguistic concept as a thesaurus concept. Thesaurus

\footnotetext{
18 Аминев Г.А. Историко-психологические предпосылки межцивилизационных конфликтов: юнгианский подход / Г.А. Аминев, Э.Г. Аминев, Цзинь Ван (г. Пекин), М.Н. Иванов, Л.Р. Шафикова // Пространство и время в восприятии человека: историко-психологический аспект : матер. XIV Mеждунар. науч. конф. - СПб. : Нестор, 2003. - Ч. 1. - С. 7-9.

19 Иванов М.Н. Типообразующие соотношения архетипа «свой/чужой» и склонности к терроризму: психофизиологические предикторы: автореф. дис. на здобуття наук. ступеня канд. психол. наук : 19.00.02 «Психофизиология» / М.Н. Иванов - Уфа, 2004. - 22 с.
} 
concept developed by Val.A. Lukov and V.A. Lukov illustrates, first, that the dichotomous distinction between "own" and "stranger" is the structuring principle here; second, and "their" and "foreign" with varying intensity length, are certain zones, concentric circles around the subject, some of which are closer, others farther from the center and in this case "over own" "less own" (oposite "less stranger" and "more stranger"); third, a thesaurus has a built-in defense mechanism against information based on anti-values (for the subject): it is perceived by the subject as alien and if it crosses the boundary of the thesaurus, then only in the form of its criticism $^{20}$.

Thus, within the thesaurus there is a differentiating principle of "own - stranger", but if you consider the thesaurus in its interaction with other thesauruses, the triad of "own - stranger - alien" becomes differentiating. Thus, one could argue that someone else, after all, to some extent his, that may be his, under certain conditions, as opposed to someone else, which in this place no thesaurus.

"Own - stranger" is the most certain value relationship that performs the function of social orientation. At first it is social: "my" - the one who belongs to me, "his" - what belongs to me, but at the same time and to the same extent "his" - from the circle to which I belong, "his" - of those things, properties or relationships on which I depend (my safety, pleasure, happiness, etc.) depend. In logical terms, the antonym of "one's own" is "not-one's own", and in value terms - "another's".

"Stranger", "unfamiliar" - are signs that are not only outside his own, but also opposed to his, and possibly - and hostile to him. It is in the paradigm of "one - another" that the reality of a person, group, community is perceived. "One 's own - alien" forms the core of a thesaurus and gives it social significance. This builds "pictures of the world", which gradually, as socialization and the acquisition of social identity of people are formed in their minds ${ }^{21}$.

The opposition of "own - stranger" is subject to consideration as a concept, an archetypal formation, as a manifestation of the internal differentiation of society and relationships between individual social

\footnotetext{
20 Луков В. А. Тезаурусы: субъектная организация гуманитарного знания / Вал.А. Луков, Вл.А. Луков. - М. : Изд-во Нац. ин-та бизнеса, 2008. - 784 с.

21 Луков В.А. А. Специфика гуманитарных наук и тезаурусная концепция / Вал.А. Луков, Вл.А. Луков // Информационный и гуманитарный портал «Знание. Понимание. Умение». - 2013. - № 1 (январь-февраль). - С. 75-85.
} 
groups, as images or feelings, and emerges as a coherent system of representations, worldviews and constructions of reality.

The basis of oppositions are the processes of existence of forms of objectification of value attitudes in social exchange, the system of norms and values, the way in which the world of man, group, community perceive in real life. The regulators of social relations are stereotypes characterized by the polarization and rigid fixation of such a dichotomy.

Opposition "own - stranger" manifests itself in the cognitive, affective and behavioral components of social identity and social perception: destructive attitudes in interpersonal relationships, social and psychological personal setting "altruism - selfishness, emotional and motivational orientations, and approval, features of social and psychological activity, types of "ego-protection" (hostility, aggression), manifestations of physical or verbal aggression against those whom a person or a person flax considers alien, in the levels and peculiarities of acceptance of others, the degree of social isolation of the individual and the group, the need for support from the environment.

\subsection{Phenomena of Intergroup Relations}

Ethnic stereotypes are an important component of social consciousness. In the structure of ethnic image, or ethnic stereotype, are distinguished ethnic educational formations (stereotypes, prejudices), values, psychological universals. By definition of V.S. Agyeev, they differ in brightness, relief, expressiveness, representation in the public and individual consciousness, practical acuity and relevance ${ }^{22}$. This explains the frequent appeal of researchers of social and national stereotypes.

In social stereotypes, according to the S.A. Kolosov, considered to be stable emotionally rich, value-defined image that is as standardized. The basis of its appearance are the psychological phenomena of generalization, generalization, categorization, schematization of information obtained in the experience. Social stereotypes as regulators of social relations are characterized by polarization of the qualities of the subject and object, as well as the rigid fixation of such a polar dichotomy ${ }^{23}$.

\footnotetext{
22 Агеев В.С. Межгруповое взаимодействие. Социально-психологические проблемы / В.С. Агеев. М. : МГУ, 1990. $-240 \mathrm{c}$.

23 Колосов С.А. Манипулятивные стратегии дискурса ненависти / С.А. Колосов // Критика и семиотика. - Вып. 7. - Новосибирск, 2004. - С. 248-256.
} 
According to E. I. Golovakha in society in recent years are increasing signs of social intolerance, which he considers antisocial personality disorder. It manifests itself wherever people's living conditions deteriorate. Instead, the search for culprits and social enemies is in place of finding ways to overcome this state of affairs. In the early years of "perestroika" polls showed that most of the respondents were intolerant of party functionaries and officials. As social, economic and political difficulties increased, intolerance became blurred, spread to representatives of different social groups, and became more aggressive ${ }^{24}$.

The social pathologies, including antisocial personality disorder, according to E. I. Golovakha leads vague and flimsy system of norms and values, massive violations of social adaptation. It is fair to note that the researcher notes that intolerance is a culture of confrontation, and consensus is a culture of compromise, tolerance, the ability to "yield to principles" for the benefit of society ${ }^{25}$.

In our opinion, one should pay attention to another phenomenon of the group - xenophobia. G. Breslav believes that the core of xenophobia is hatred of foreigners. He also notes the existence of a significant positive link between hate and ethnic intolerance, a natural consequence of which is social discrimination ${ }^{26}$.

In the words of G.S. Pomerantz: "Xenophobia in general clearly differentiates" us outsiders "with which the person is ready pobratatysya and" alien outsiders ", which - not $^{27}$.

The researcher also identifies xenophobia as a kind of human protective reaction that has a biological basis: it is a reaction to what is considered dangerous. He also clarifies that animals in the wild almost never show aggression towards what they think may be dangerous. Unlike animals, it is important for man to show aggression towards what or whom he regards as alien - physical or at least verbal, besides the aggression of xenophobes is necessarily motivated by something. "Aggression serves to mask the fear of the unknown. Therefore, the more developed in society (or in any group) xenophobia, the greater the fear of these people against the unknown.

\footnotetext{
24 Головаха Е. И. Социальные патологии посткоммунистического общества / Е.И. Головаха // Политическая мысль. - 1994. - № 4. - С. 36-45.

25 Головаха Е. И. Социальные патологии посткоммунистического общества / Е.И. Головаха // Политическая мысль. - 1994. - № 4. - С. 36-45.

${ }^{26}$ Breslavs G. et al. Vai m s esam ieciet gi? Sabiedrbas etnisk s ieciet bas monitoringa metodikas izveide / G. Breslavs, U. Bele, L. Derjabo, I. Piinska, J. Roze. Riga: Salus, 2008.

${ }^{27}$ Померанц Г.С. Кто такие «чужаки»? / Г.С. Померанц. - Знамя. 1991. - № 11. - С. 183-187.
} 
Therefore, it can be argued that xenophobia, as a kind of "us and them" effect, is a kind of human defensive response to what is considered dangerous.

In general, a clear distinction between "strangers" with whom a person is able to build even sufficiently close relationships, and "strangers", which is considered dangerous to approach, from one point of view, maximizes schematics of social perception between individuals and groups, and from another can act basis, a structural principle, such as in the thesaurus concept.

Judgments about strangers will inevitably be simplified over time by stereotyping, stigma and prejudice. The stereotyping of thinking establishes in the minds the understanding of who is "one's own" and who is "stranger", who is "one's relative" and who is "another's relative", who is "one's own" "stranger" and who is another's "stranger".

One of the conditions for the emergence of hatred is the separation of one's own group with other groups, that is, the emergence of the so-called "we-they" effect. Distinction can be made by virtually any criterion: based on ethnicity, nationality, political views or social status. G. Breslav, noting the variability of hate manifestations, also defines the diffuse nature of the object of hatred, noting that hatred is a derivative of social identity. The difference between one's own group and other groups often causes the member and other groups to be viewed in a negative context. They may even be considered a threat to their group or may be devalued based on their "differences" 28 .

M.M. Slyusarevskyy notes that "human"we"... older than "I". Therefore, the individual psyche is still not always able to withstand the social, the latter is often stronger than the individual. Individual consciousness depends on the generational layers of consciousness of the masses within which it functions; the personality is influenced by the quantified portions of the worldview concentrated in the so-called social stereotypes" 29 .

B.F. Porshnev group investigating the phenomenon of "we - they" pointed to the primacy of the origin of the image "they", for it is through the understanding of the term ("they" - is "not like us") community can recognize itself as such. He also gave a thorough analysis of the socio-

\footnotetext{
${ }^{28}$ Бреслав Г. Ненависть как предмет психологического исследования // Вопросы психологии - 2011. № 2 С. $136-148$.

${ }^{29}$ Слюсаревський М.М. «Ми» і «Я» в сучасному світі: Вибрані твори / М.М. Слюсаревський. - К. : Міленіум, 2009. - 340 с. - С. 113-120.
} 
psychological phenomena of the formation of subjective and group "we", but emphasized the primacy of the phenomenon of "they" ("alien"), which became a significant social fact for the development of sociality of the individual $^{30}$.

B.F. Porshnev speaking about the social and psychological content of selected categories, notes that in primitive society "we" - it's always "people" in the literal sense, that people in general, while "they" - not quite people. The name of many tribes and peoples in translation means simply "people." This again illustrates that in the psychological sense, "we" is a very difficult psychological category ${ }^{31}$.

Modern Ukrainian psychologist P.P. Ghornostay takes the phenomenon of "we" as a symbolic group role when individual identity is replaced by various forms of group consciousness, that person depersonalisation ${ }^{32}$.

According to I.C. Daniluk, creating an image of the group "We" can be understood as a determinant in stereotyping internal and external enemy ${ }^{33}$.

Awareness of the person belonging to a particular ethnocommunity, identifying his "I" to "we" disengagement "we - they" respect "their" and "other" communities, according to G.S. Lozko has a special place among the subjective symptoms nation and national consciousness, which can be somewhat arbitrarily called the result of self-knowledge of the representatives of the nation ${ }^{34}$.

Ethnic consciousness is defined as one form of relation of a certain ethnic group to other groups. According to A.M. Lozova, ethnic consciousness produces an ethnic image of the world $35,36,37$.

\footnotetext{
30 Поршнев Б.Ф. Противопоставление как компонент этнического самосознания / Б.Ф. Поршнев. М. : Наука, 1973. - 346 с. - С. 163-184.

31 Поршнев Б.Ф. Противопоставление как компонент этнического самосознания / Б.Ф. Поршнев. М. : Наука, 1973. - 346 с. - С. 163-184.

32 Горностай П.П. Психологічний феномен «Ми» / П.П. Горностай // Соціальна психологія. - 2006. № 2. - С. 88-96.

33 Данилюк І.В. Мова як чинник згуртованості групового «Ми» / I.В. Данилюк // Соціальна психологія. - 2008. - № 3. - С. 105-112.

34 Лозко Г.С. Етнологія України: філософсько-теоретичний та етнорелігієзнавчий аспект: навч. посіб. / Г. Лозко. - К. : АртЕК, 2001. - 304 с.

35 Лозова О.М. Психосемантика етнічної свідомості : Монографія / О.М. Лозова. - К.: «Освіта України», 2007. - 402 с.

36 Лозова О.М. Мова в етнічній картині світу / Лозова О.М. // Вісник Київського міжнародного університету. Збірник наукових статей. - Серія: Психологічні науки.- Вип. 13. - К.: КиМУ, 2009. - С. 110-123.

37 Лозовая О. Н. Психология этнического сознания в Украине: история, настоящее, перспективы / Лозовая О.Н. // Историческая психология: истоки и современное состояние : Монография / под науч. ред. И.Н. Коваля, В.И. Подшивалкиной, О.В. Яремчук. - Одесса: Одесский национальный університет им. И.И. Мечникова, 2012. - С. 115-129.
} 
Ethnicity is a mature group and exists as a stable system that opposes itself to everyone else on the basis of the distinction of "we are not us" ("they"), "our own - strangers", "best - worst" and so on. And this recognition of the ethnic collective of its unity is the main feature of the ethnic group, reflecting in the minds of people its existing integrity as a system. But ethnicity is a product not only of consciousness but also of human nature, a reflection of a certain physical or biological reality ${ }^{38}$.

Increasing interethnic tensions contribute to the manifestation of the most characteristic characteristics of the people inherent in the past, the adaptive ways of its behavior, which are entrenched as the most successful. Perceptions of them form an important part of ethnic identity, interact with the educational establishments and form connective structures of ethnicity, defining the ways of intra-group organization and mobilization of the group. In modern ethnopsychology, ethnic auto -stereotypes representations and characteristics of members of "their" ethnic group are distinguished, and ethnic hetero - stereotypes - images of representatives of "other" ethnic groups. As demonstrated numerous empirical studies almost always ethnic avtostereotypy differ significantly greater positivity, than ethnic heterostereotypy.

\section{CONCLUSIONS}

As a result of the theoretical analysis, we can conclude that hatred is a complex phenomenon of the human sensory sphere, which to a certain extent determines its existence. The category of hatred is interdisciplinary in philosophy, cultural studies, linguistics, personality psychology and social psychology.

With participant scientific opinion defines the ambivalent nature of hatred: on the one hand, irrationality, and the other - the rationality and necessity. It is determined that the object of hatred is usually blurred, mythologized, and hypertrophied. Hate is not an innate feeling, but a person's acquired life. Sometimes hatred develops in a person as a result of her ideas about how external circumstances affect the individual.

Poor development of phenomenology and hate issues is associated with the taboo of discussing this topic in society, as well as a number of moral, ethical and organizational problems associated with the study.

\footnotetext{
38 Лозко Г.С. Етнологія України: філософсько-теоретичний та етнорелігієзнавчий аспект : навч. посіб. / Г. Лозко. - К. : АртЕК, 2001. - 304 с.
} 
At present, there is no lapidary and uniquely worded concept of hatred, but summing up the diversity of thoughts, we can determine that hatred is a persistent negative feeling of the subject directed at another person, group of people, inanimate object or phenomenon that represents a real or imagined threat, or the subject's values. This feeling is characterized by the constant desire of the subject to inflict as much pain or suffering (up to the destruction) of the object of hatred, real or imagined, as possible.

It is determined that the predictors of hatred can be different factors of intergroup and interpersonal relationships, such as: effects of "we-they", "own - stranger", social and ethnic stereotypes, xenophobia and others.

At present, a lack of empirical basis for hate studies is causing some confusion in scientific research, which necessitates further fundamental and applied research.

\section{SUMMARY}

The paper highlights contemporary theoretical approaches to the study of hatred. The interdisciplinary nature of the problem has been identified: the category of hatred is considered in philosophy, cultural studies, linguistics, personality psychology and social psychology. The basic social and psychological connections within the framework of the polyparadigmal approach are outlined. The place of hate category in the system of interpersonal and intergroup relations was determined. An attempt is made to define the concept of hatred and differentiate it from other social and psychological categories. The place of hate category in the system of intergroup relations is determined. It is determined that hatred is a complex phenomenon of the human sensual sphere, which determines its existence. Hate has been found to have a unique neurobiological pattern of brain activity.

\section{REFERENCES}

1. Агеев В.С. Межгруповое взаимодействие. Социальнопсихологические проблемы / В.С. Агеев. - М. : МГУ, 1990. - 240 с.

2. Аминев Г.А. Историко-психологические предпосылки межцивилизационных конфликтов: юнгианский подход / Г.А. Аминев, Э.Г. Аминев, Цзинь Ван (г. Пекин), М.Н. Иванов, Л.Р. Шафикова // Пространство и время в восприятии человека: историко- 
психологический аспект : матер. XIV Междунар. науч. конф. - CПб. : Нестор, 2003. - Ч. 1. - С. 7-9.

3. Белинская Е.П., Тихомандрицкая О.А. Социальная психология личности : учеб. пособ. для вузов / Е.П. Белинская, О.А. Тихомандрицкая. - М. : Аспект Пресс, 2001. - 301 с.

4. Бреслав Г. Ненависть как предмет психологического исследования // Вопросы психологии - 2011. - № 2. - С. 136-148.

5. Головаха Е.И. Социальные патологии посткоммунистического общества / Е.И. Головаха // Политическая мысль. - 1994. - № 4. C. 36-45.

6. Горностай П.П. Психологічний феномен «Ми» / П.П. Горностай // Соціальна психологія. - 2006. - № 2. - С. 88-96.

7. Гумилев Л.Н. Этногенез и биосфера Земли / Л. Н. Гумилев. СПб. : Ленинградское Изд-во, 2011. - 560 с. - С. 25-27, 92-96.

8. Данилюк І.В. Мова як чинник згуртованості групового «Ми» / I. В. Данилюк // Соціальна психологія. - 2008. - № 3. - С. 105-112.

9. Иванов М.Н. Типообразующие соотношения архетипа «свой/чужой» и склонности к терроризму: психофизиологические предикторы: автореф. дис. на здобуття наук. ступеня канд. психол. наук : 19.00.02 «Психофизиология» / М.Н. Иванов - Уфа, 2004. - 22 с.

10. Кернберг О. Отношения любви: норма и патология / О. Кернберг. Пер. с англ. М.Н. Георгиевои.-М.: Независимая фирма "Класс", 2000. - 256 с. - (Библиотека психологии и психотерапии, вып. 76).

11. Колосов С.А. Манипулятивные стратегии дискурса ненависти / С.А. Колосов // Критика и семиотика. - Вып. 7. Новосибирск, 2004. - С. 248-256.

12. Лозко Г.С. Етнологія України: філософсько-теоретичний та етнорелігієзнавчий аспект: навч. посіб. / Г. Лозко. - К. : АртЕК, 2001. - 304 c.

13. Лозова О.М. Мова в етнічній картині світу / Лозова О.М. // Вісник Київського міжнародного університету. Збірник наукових статей. - Серія: Психологічні науки.- Вип. 13. - К.: КиМУ, 2009. C. $110-123$.

14. Лозова О.М. Психосемантика етнічної свідомості : Монографія / О.М. Лозова. - К.: «Освіта України», 2007. - 402 с. 
15. Лозовая О.Н. Психология этнического сознания в Украине: история, настоящее, перспективы / Лозовая О.Н. // Историческая психология: истоки и современное состояние : Монография / под науч. ред. И.Н. Коваля, В.И. Подшивалкиной, О.В. Яремчук. Одесса: Одесский национальный університет им. И.И. Мечникова, 2012. - C. 115-129.

16. Луков В.А. Специфика гуманитарных наук и тезаурусная концепция / Вал.А. Луков, Вл.А. Луков // Информационный и гуманитарный портал «Знание. Понимание. Умение». - 2013. - № 1 (январь-февраль). - С. 75-85.

17. Луков В.А. Тезаурусы: субъектная организация гуманитарного знания / Вал.А. Луков, Вл.А. Луков. - М. : Изд-во Нац. ин-та бизнеса, 2008. - $784 \mathrm{c}$.

18. Померанц Г.С. Кто такие «чужаки»? / Г.С. Померанц. - Знамя. 1991. - № 11. - С. 183-187.

19. Поршнев Б.Ф. Противопоставление как компонент этнического самосознания / Б.Ф. Поршнев. - М. : Наука, 1973. 346 c. - C. $163-184$.

20. Слюсаревський М.М. «Ми» і «Я» в сучасному світі: Вибрані твори / М.М. Слюсаревський. - К. : Міленіум, 2009. - 340 с. C. $113-120$.

21. Спиноза Б. Избр. произв.: В 2 т. Т. 1. М: Политиздат, 1957. C. $467-468$

22. Чужой [Электронный ресурс]. - Режим доступа : http://ecdejavu.ru/c/Chuzoy.html.

23. Шихирев П.Н. Современная социальная психология / П. Н. Шихирев. - М. : ИП РАН, КСП+, Академический Проект, 1999. $-447 \mathrm{c}$.

24. Экман, Пол. Психология эмоций / пер. с англ. В. Кузин.СПб.: Питер, 2010. - 336 с.

25. Allport G.W. The nature of prejudice. Garden City, NY: Doubleday Anchor Books, 1958.

26. Bar-Tal D. Collective memory of physical violence: Its contributions to the culture of violence // G. Salomon, B. Nevo (eds). Peace education: The concept, principles and practice around the world. Mahwah, NJ: Lawrence Erlbaum Associates, 2002, P. 27-36. 
27. Baumeister R.F., Butz D.A. Roots of hate, violence, and evil // Sternberg R.J. (ed.). The psychology of hate. Washington, DC: APA, 2005. P. 87-102.

28. Breslavs G. et al. Vai m s esam ieciet gi? Sabiedrbas etnisk s ieciet bas monitoringa metodikas izveide / G. Breslavs, U. bele, L. Derjabo, I. Piinska, J. Roze. Riga: Salus, 2008.

29. Breslavs G., Tyumeneva J. Toward operationalization of the hate concept: Is hate an opposite to love? // The paper presented at the 14th European conference on Personality, Tartu, July 16-20, 2008.

30. Fitness J. Anger in the workplace: An emotion script approach to anger episodes between workers and their superiors, co-workers and subordinates // J. of Organizational Psychol. 2000. V. 21. P. 147-162.

31. Kimberly Dozier Breathing the Fire: Fighting to Survive, and Get Back to the Fight.

32. McKellar P. Provocation to anger and development of attitudes of hostility // Brit. J. Psychol. 1950. V. 40. P. 104-114.

33. Semir Zeki, John Paul Romaya. Neural Correlates of Hate / Plos One. https://journals.plos.org/plosone/article?id=10.1371/journal.pone.0003556

34. Sternberg R.J. (ed.). The psychology of hate. Washington, DC: APA, 2005.

\section{Information about the author:} Bielavin S. P.

$\mathrm{PhD}$ in Social Psychology, Associate Professor at the Department of Psychology and Pedagogy of the Scientific and Humanitarian Institute of the V. I. Vernadsky Taurida National University 33, Ivana Kydri str., Kyiv, 01042, Ukraine 


\section{SOCIAL-PSYCHOLOGICAL ASPECTS OF INTRAGROUP ADJUSTMENT IN ADOLESCENTS PENITENTIARY SYSTEMS}

\section{Bielavina T. I.}

\section{INTRODUCTION}

Changes in modern Ukraine cover the most diverse layers of social life, which is constituted by different traditions, norms of behavior, social institutions, and touches upon philosophical, scientific, moral, legal, political, aesthetic and other aspects of it. Most of the socio-economic, political changes affect the spheres of culture, family, education and upbringing, for which the fundamental values of human consciousness are inherent in the greatest extent. In the context of the ongoing transformations, they retain the greatest stability and remain the most important social institutions; they cannot but be influenced by large-scale changes in the economic, social, and cultural context.

The criminal subculture, being an existing objective reality, occupies a certain place in the system of human relations and values. Therefore, along with the priority tasks facing psychological science today, one of the key is the problem of the study of a special system of intragroup relationships and interpersonal communications in special educational institutions with varying degrees of prescribed behavior and mode.

In this connection, the problem of the vital activity of the individual and the group in the penitentiary systems, which, to a certain extent, are seen as a reduced model of a sociable congruence, deserves attention. It can be described as a problem related to group formation in conditions of forced relative localization and isolation of the group in relation to a certain contingent, a specific type of joint activity, to a certain age, gender, from the standpoint of not only general, age and pedagogical, but also social psychology.

On this basis, it is necessary to determine the socio-psychological aspects of intergroup and intgroup interaction in adolescent groups, its social-perceptual aspect; to study peculiarities of intragroup structure of real groups in conditions of penitentiary institution. 


\section{Social-psychological studies of personalities and groups of minors}

The social reality of modern times, the change of attitudes regarding spiritual and material values in the broad society, in certain social strata and specific groups caused both positive changes and new problems. They were caused by the collapse of previous mono-ideologized models of relations between society and the state, the destruction of myths, stereotypes, prejudices.

In both domestic and foreign practice, there is considerable theoretical and empirical experience in the development of the problem of group and intergroup interaction, mutual perception in the group and between groups, intragroup structuring. It is advisable to analyze how much the problem of the status of the teenager in the system of his social relations in special conditions is studied in the psychological literature.

Back in the late XIX - early XX centuries, attempts were made to study the extent and nature of the group's influence on the mental functions, behavior and activities of the individual. This was reflected in the scientific publications of G. Zimmel ${ }^{1}$ and C. Kuli ${ }^{2}$, which can be attributed to the beginning of the experimental stage in the study of groups (for example, the theory of primary groups, the theory of the "mirror self"). In the first third of the twentieth century, researches within this problem became widespread and were reflected in the works of V. Bekhterev (1921, 1923) ${ }^{3}$, V. Moede ${ }^{4}$, J. Moreno ${ }^{5}$, F. Allport ${ }^{6}$, G. Tarde ${ }^{7}$.

On the basis of the accumulated experimental material, at this stage the conclusion was made about the significant influence of direct contact of people in the group on the course of mental processes and the emergence of "extra-individual" phenomena (eg, facilitation, inhibition). It has been established that these and other "extra-individual" phenomena are characteristic of a certain set of individuals as a whole.

\footnotetext{
1 Зиммель Г. Социальная дифференциация: Социологические и психологические исследования / Г. Зиммель // Избран. в 2 т: 2Т: Созерцание жизни. - М: Юрист. - 1996. - 164 с.

${ }^{2}$ Кули Ч. Человеческая природа и социальный порядок : [Науч. изд.] : пер. с англ. / Ч. Кули М. : ИдеяПресс : Дом интеллектуальной книги, 2000. - 309 с.

${ }^{3}$ Бехтерев В.М. Основные задачи рефлексологии физического труда [Текст] / В.М. Бехтерев // Вопросы изучения и воспитания личности. 1919. № 1. С. 51.

${ }^{4}$ Moede W. Experimentelle Massenpsychologie. Beitrage zur Experimentalpsychologie der Gruppe. Leipzig: Hirzel, 1920. - 239.

5 Морено Я.Л. Социометрия: Экспериментальный метод и наука об обществе / Пер. с англ. А. Боковикова. - М. :: Академический проект, 2001. - 320 с.

6 Олпорт Г. Становление личности: Избранные труды / [Пер. с англ. Л. В. Трубицыной и Д. А. Леонтьева]; под общ. ред. Д.А. Леонтьева. М.: Смысл, 2002. - 462 с.

${ }^{7}$ Тард Г. Социальные законы Пер. с фр. Изд. 2-е. - М.: Книжный дом «ЛИБРОКОМ», 2009. - 64 с.
} 
Finding and fixing differences in human behavior in conditions of either isolation or publicity was the first step in the comparative study of individual and group effectiveness, in identifying a number of purely group phenomena and factors of subjective psychological order.

The achievement of this period of scholarly search has become a persistent recognition of the existence within formal groups of informal divisions that are formed on the basis of interpersonal emotional relationships. The formation of group norms and values, largely determine the behavior and activity of the individual. The study of these phenomena was carried out in two aspects of the life of the group: formally set functional and business relationships, as well as informal emotionalpersonal relationships that have a decisive influence on them.

The problem of social-psychological interaction of personality and society, its functionally-business and emotional-personal relationships in large and small groups is devoted to the scientific search of many domestic researchers of the second half of the twentieth and the beginning of the twentieth centuries. (G.Andreeva ${ }^{8}$, A. Asmolov ${ }^{9}$, S. Bagretsov ${ }^{10}$, P. Ghornostay ${ }^{11}$, A. Petrovsky ${ }^{12}$, etc.).

In accordance with the concept of personalization, developed at the end of the twentieth century, A. Petrovsky distinguished three processes of personality formation: adaptation as becoming socially typical; individualization, as the acquisition of individuality; integration as a change in the life of others. In this context, the distinctive feature of adolescence is the prevalence of individualization over adaptation, and the adolescent's personality develops in the developing group, the teenager defines himself through the group, through society. Teenagers are constantly included in the system of interpersonal relationships in different groups, interacting and communicating with each other ${ }^{13}$.

On the basis of the accumulated research material the conclusion was made about the significant influence of joint activity on the development of the human psyche. Moreover, the "internal" mental processes are

\footnotetext{
${ }^{8}$ Андреева Г.М. Социальная психология. М.: Аспект-Пресс. - 2000. С. 186-190, 274-288.

9 Асмолов А.Г. Психология личности: культурно-историческое понимание развитие человека (3-е изд. Испр и доп.). - М., Академия, Смысл, 2007. - 528 с.

${ }^{10}$ Багрецов С.А. и др. Диагностика социально - психологических характеристик малих груп. - СПб.: Питер,1999. - 638 с.

11 Психологія групової ідентичності: закономірності становлення: [монографія] / [П.П. Горностай, О.А. Ліщинська, Л.Г. Чорна та ін.] ; за наук. ред. П.П. Горностая. - К. : Міленіум, 2014. - 252 с.

${ }_{12}$ Петровский А.В. Психология развивающейся личности: монография. М.: Педагогика, 1987. - 240 с.

13 Петровский А.В. Психология развивающейся личности: монография. М.: Педагогика, 1987. - 240 с.
} 
transformed forms of "external" group activity of people, the result of their cooperation. In the course of adulthood, relationships with peers become more selective and stable, and the basis of preference and choice are the personal characteristics of the partner. Status position in the group is more often associated with intellectual and volitional characteristics.

The organization of a teenage group is largely determined by the position of its members. The teenager's ability to accept the goals of the group, its motives, values, its willingness to take initiative, to take responsibility characterizes its involvement in the life of a cohesive group of high level of development. This concept, in a certain way, differs in content with the concept of the status of the teenager's personality position in the system of interpersonal relationships, although these phenomena are closely related. Status reflects the position of the individual in the system of interpersonal relationships, and inclusiveness is considered as adequate or inadequate participation of the person in the life of the group, in the realization of its goals. Adequacy is determined by initiative, activity, efficiency, and inadequacy is determined by indifference, negativism, and irrelevant following by the group. When a group views a teenager's actions as worthy of imitation or approval, a state of certainty arises and an awareness that the group is legalizing and upholding or sanctioning its values. On the other hand, in the absence of adequate function in the group and the proper status position of the teenager, the importance of emotional bonds are decisive, and disturbances in this area cause tension, frustration, neuroses.

The phase of adaptation in adolescence is expressed in satisfying the need to be like a "significant other". This phase involves a number of tasks: to be like the reference peers, to be what the peers want to see him and to build relationships with adults as their peers reference them. A significant number of settings in adolescence are related to one or more social groups, as evidenced by the study of the influence of prestige, leadership of opinions, the rejection of membership groups by those who hold low status, the influence of external groups on the level of personality claims. In recognition of this fact, the term "reference group", which was first used by G. Hayman in 1942 to refer to a group of people with whom a subject compared himself to determine his status, was widely used. As a result, the comparison had a decisive influence on the self-esteem of one's status. In T. Newcom's (1953) works, the notion of referentiality is associated with a positive and negative attitude towards a group or groups 
and is enshrined in M. Sheriff's (1948) works as a point of reference for self-esteem and for the formation of a picture of the world and other researchers.

The phase of individualization, relatively prevalent at this age, as already noted, is characterized by the refinement and development of ideas about themselves, the active development of self-awareness, the expansion of contacts with peers. Personal relationships are of particular importance, and the further development of role-playing relationships contributes to the expansion of social ties.

Communication with significant people during this period is a source of both positive and negative experiences. Moreover, the negative can be compensated in the course of communication with others. However, if the teenager compensates for the loss in satisfactory communication with others, conflicts do not necessarily lead to social maladaptation. If he does not have such an opportunity, then compensation is obtained in another environment that may be asocial. In the phase of individualization, the need to "attract attention" is met by means developed in the system of relationships with peers, which can be manifested in the extraordinary behavior, in clothing, in sports achievements, emphasized courage, or in alcoholism, narcotics, early sexual debuts, excess audacity. This may be the basis for the subsequent criminalization of the teenager and his placement in a penitentiary

The integration of the teenager determines his / her readiness for the next period of development, which often goes beyond the formal group: school class, group in professional institute, college.

In general, theoretical analysis has necessitated the need for sociopsychological studies of features, patterns in the development of adolescent groups, their dynamics, phenomena of intragroup interaction and its socialperceptual features in special conditions of social deprivation.

\section{Introgroup structure and social perception in penitentiary institutions for minors}

Many theoretical and experimental works in the social, legal, penitentiary psychology of the post-Soviet period of the last decades of the late twentieth and early twentieth centuries were devoted to the study of the processes of group formation in special conditions, including in the 
conditions of social deprivation... [M. Bashkatov ${ }^{14,15}$, O. Betza ${ }^{16}$, T. Belavina ${ }^{17}$, M. Kondratyev ${ }^{18}$, V. Krivusha, V. Sinev ${ }^{19}$, etc.).

As already noted, the process of forming the necessary personal qualities is largely determined by the features of interpersonal relationships in each specific community. Issues related to the dynamics of personality and group development in penitentiary systems can also be attributed to the problem of group formation, intragroup structure, dynamic processes in the group and between groups in conditions of forced relative isolation of the group. There are in view of the group of juveniles sentenced to imprisonment, the peculiarities of the conditions of development of their personality, as well as the intragroup structure in the institutions of the juvenile law enforcement system.

The problem under study aims to identify the socio-psychological aspects of the formation and dynamics of intergroup and intragroup relationships of convicted adolescents, to determine what the impact of specific real social groups on these processes in conditions of forced isolation from society in a broad understanding of its significance.

One of the central problems of social psychology is traditionally considered to be the problem of group differentiation as an intra-group structure. Most of the authors of the study of group structuring reduce the concept of intragroup structure to consider it from the standpoint of "formality" and "informality". That is, as the relationship between the functional structure of the group and the structure of interpersonal relationships allows us to analyze group structuring from the standpoint of the "functional-emotional" approach ${ }^{20}$.

The idea of a small group as a specific element of the general social system implies the need to distinguish between external and internal

\footnotetext{
14 Башкатов И.П., Фицула М.Н. Основы исправления и перевоспитания несовершеннолетних осужденных в воспитательно-трудовых колониях. М.:ОВТК ГУИТУ - 1984. 324 с.

15 Башкатов И.П. Социально-психологические особенности развития криминогенных групп подростков // Психология и профилактика асоциального поведения несовершеннолетних. Тюмень: ТГУ, 1985. - C. $15-26$.

${ }^{16}$ Беца О. Соціальна адаптація осіб, звільнених із місць позбавлення волі // Соціальна політика і соціальна робота, 2002. - № 2. - С. 5-15.

17 Белавіна Т.І. Міжособистісні відносини в умовах соціальної депривації // Соціально психологічний вимір демократичних перетворень в Україні / За ред. Максименка С.Д., Циби В.Т., Шайгородського ЮЖ та ін. - К.: Український центр політичного менеджменту, 2003. - С. 357-369.

${ }^{18}$ Кондратьев М.Ю. Социальная психология закрытых образовательных учреждений. - СПб.: Питер, $2005-304 \mathrm{c}$

${ }_{19}$ Синьов В.М., Кривуша В.І. Пенітенціарна педагогіка: в запитаннях і відповідях: [Навчальний посібник] / В.М. Синьов, В.І. Кривуша. - К: ПМ Леся, 2002. - 123 с.

${ }^{20}$ Андреева Г.М. Социальная психология. М.: Аспект-Пресс. - 2000. С. 186-190.
} 
structure: the first is understood as a complex of socially defined causes of its formation, and the second is denoted by the problem of intragroup structuring. a set of functions corresponds to such a structure, which is a characteristic of the role ${ }^{21}$.

In M. Kondratiev's studies, the model of group differentiation is described in terms of "monostructure" and "polystructure" $"$. The monostructure characterizes in all spheres of group activity the situation of invariance of status hierarchy, which implies the fixation of low or high status always behind the same members of the group. These characteristics of the group in the conditions of the penitentiary institution have been obtained in numerous studies, including in the author's own studies ${ }^{23}$. Polystructure implies the presence of a large number of differing rank structures, each reflecting a status hierarchy in each individual sphere of group activity. Each of these types of structuring has both advantages and "disorganizing tendencies", different in character. The monostructure of interpersonal relationships in group activities, on the one hand, allows to quickly and effectively solve the tasks set, on the other - creates a rigid separation of statuses, leading them to polarization. And for the solution of various problems, for the optimization of interpersonal relations, polystructuring, which, at the same time, is able to cause intragroup division $^{24}$ will become more favorable.

In the context of this task, it is necessary to emphasize the importance of self-esteem in personal development. In the scientific literature, it is considered from various positions: as a component of self-awareness, as a determinant of behavior, etc. First of all, we note that self-esteem is the area of interest of various psychological disciplines: age, pedagogical, differential psychology, pathopsychology. Its characteristics are defined, research methods are developed, experience of theoretical and experimental study of self-esteem is accumulated.

In a number of studies, the dependence of the formation of an objective basis of the evaluative attitude of the individual towards himself

\footnotetext{
${ }^{21}$ Андреева Г.М. Социальная психология. М.: Аспект-Пресс. - 2000. С. 274-288.

${ }^{22}$ Кондратьев М.Ю. Социальная психология закрытых образовательных учреждений. - СПб.: Питер, $2005-304$ c.

23 Бєлавіна Т.І. Міжособистісні відносини в умовах соціальної депривації // Соціально психологічний вимір демократичних перетворень в Україні / За ред. Максименка С.Д., Циби В.Т., Шайгородського ЮЖ та ін... - К.: Український центр політичного менеджменту, 2003. - С. 357-369.

${ }^{24}$ Кондратьев М.Ю. Социальная психология закрытых образовательных учреждений. - СПб.: Питер, 2005 - 304 c.
} 
in the process of conscious development of the rules of relations in the real contact group is traced, the social determination of self-esteem is emphasized. As a structural component of the mental structure of personality, self-esteem determines the degree of its orientation in interpersonal communication. Self-esteem influences the effectiveness of the activity and the further development of the individual as a social quality of the individual. Its characteristics: resilience, adequacy, level of adaptability, and so on, are fundamental in the choice of behavior line, communication partner, as well as in relationships with others. It can be concluded that the interaction of the individual and the group gives birth to an infinite number of value systems that develop among members of a complex community, in which one can find support for almost any human manifestation.

Already in the first studies of self-esteem sounded socio-psychological terms. Thus, K. Levin ${ }^{25}$, L. Festinger ${ }^{26}$, and others identified, along with situational and personality, socio-psychological factors, such as group norms, standards, as determinants. Therefore, not only the individual but also the [...] group is the subject of many studies of self-esteem.

The formation of personality characteristics is inextricably linked to the success or failure of integration of the individual in the reference group and the level of development of that group, on which the conditions for satisfying the need for personalization depend. However, in groups with an antisocial focus (such as criminally oriented ones), the motive for avoiding failure due to the group's severe sanctions in case of failure is great. Thus, the need for social adjustment to the group is obvious, but the group can also be evaluated for the adequacy of one or another of its members. All our judgments, judgments, tastes, depend on the views of those we consider experts. If a community or group tries to equalize some of its members with others or leave them in isolation, it may be perceived as inadequate to the individual's needs and become a source of frustration for the individual's social needs.

If the norms of the membership group cease to conform or work for self-esteem, or the group impedes its preservation, the individual will seek to leave that group either physically or psychologically, that is, to select an

\footnotetext{
25 Левин К. Теория поля в социальных науках / [Пер. Е. Сурпина]. - СПб.: Речь, 2000. - 368 с.

${ }^{26}$ Festinger, L. Wish, expectation and group standards as factors influencing level of aspiration // Journal of Abnormal and Social Psychology, 1942, 37 (2), 184-200.
} 
external group as a standard. In this sense, the group is an active creator of standards and norms.

Changing the social status of a group in a relatively broad social environment can be a determinant of the dynamics of self-esteem in the group. Attempts to trace the dependence of self-esteem on belonging to a particular social group were made mostly in foreign psychology, by H. Heckhausen (1986), K. Levin ${ }^{27}$ and L. Festinger ${ }^{28}$. Despite the considerable accumulated theoretical material, the data on the impact of the broader society on self-esteem are scanty, they are scattered, and the problem requires further elaboration.

The cultural and social context, traditions, stereotypes of behavior, corresponding to, including, gender role, determine the direction of sexual socialization. The adult community that directly surrounds the child from birth, controls role behavior in terms of their acceptability. The system of self-esteem and preferences, the consciousness of one's gender, is formed under the influence of the attitude of others. During puberty, under the influence of hormonal processes and the influence of others, sexual identity is supplemented by certain sexual and erotic orientations and interests. Therefore, the gender aspect of this process deserves separate study beyond this private study.

In our study, we need to make some observations about the specifics of the sample, which represents the respondents: on the one hand, adolescents brought up in orphanages, and on the other, inmates of closed-type crime departments. These educational institutions have relatively similar characteristics: adequate socialization of students, social deprivation, as a partial limitation of opportunities in establishing new social ties and independence of group choice, etc. But their group isolation is different. Boarding students find themselves detached from the social environment by force, due to circumstances, without infringing on their rights and reducing their social status. Adolescents in a penitentiary institution are in isolation, to which the society consciously exposes them.

It is customary to single out relatively specific distinctive psychological traits of the students in the penitentiary systems: emotional instability, initial dependence on society, high stereotyping of public

\footnotetext{
27 Левин К. Теория поля в социальных науках / [Пер. Е. Сурпина]. - СПб.: Речь, 2000. - 368 с.

${ }^{28}$ Festinger L. Wish, expectation and group standards as factors influencing level of aspiration // Journal of Abnormal and Social Psychology, 1942, 37 (2), 184-200.
} 
opinion regarding their social position and stigmatization. These and some other features have a significant effect on behavior, especially on reactions to frustration and so on.

Research conducted by the author in similar groups earlier revealed some common features in the socio-psychological manifestations of both adolescents - boarding students and graduates of the departments of the department for the execution of crimes for committing crimes. To exclude indicators related to age-specific adolescent characteristics, high school students of the general school acted as a control group.

The findings revealed that the situation of the juvenile prisoners in closed institutions is significantly different from the situation and behavior of adolescents. raised in a boarding school. The total deprivation of the penitentiary system significantly affects the self-attitude of its students clearly in a more unfavorable way.

At the same time, purposeful observation, discussions with orphanage staff and other research participants made it possible to conclude that there is a strong stigma on the part of the wider society, both those adolescents who are in detention and those who are brought up outside the family, but less deprived of spatial movement, choice of group, establishment of new social ties, freedom to choose forms of leisure.

It should be defined as a factor of negative influence on the process of personal formation of teenagers in a small group and in the conditions of society. The possibility of personal deformation becomes apparent, and its extent and features are likely to be determined not only by the social situation of development (objectively), but also by the attitude of the subjects themselves, by how they perceive the given situation (subjectively).

Particularly noteworthy is the fact that until now, there has been virtually no research aimed at examining the features of awareness of perception of the broader society. Such a task made it possible to make some assumptions, in that part, where the specificity of interpersonal relationships and group formation is supposed to depend on the evaluative attitude of the society as a whole and on the awareness of the contingent sampling of the social status of the social structure and the group to which they belong. 


\section{3. "I-confrontation" and "I-identification" in conditions of forced comparison of yourself with peers}

The study participants are closely related to the degree and nature of the orientation of the "Self-confrontation" and "Self-identification" processes in the context of forced comparison of peers who are brought up in a fundamentally different social situation: in the orphanage or in institutionally closed educational and educational institutions. institutions of the enforcement system.

The paper attempts to summarize some of the results concerning precisely the socio-psychological issues of forming a self-esteem personality, the social-perceptual aspects of this process, on the basis that the condition of understanding the personality is a psychological analysis of the communities in which it is included. That is, it is about the dependence of self-esteem on the characteristics of small groups and interpersonal interactions, in particular, the influence of the reference group. Self-esteem depends on how the group standards are formed and changed, the parameters of self-esteem, and how each member of the group takes part in their formation and change. Often this problem is solved by designating an alternative: either the individual passively accepts the norms and expectations of the group, that is, demonstrates conformal behavior, or maintains his "level of self." In such a case, his confrontation with the group is inevitable.

The revealed patterns partially reveal the peculiarities of the awareness of teenagers serving their sentence in penitentiary conditions, the specifics of the attitude of orphanage students to them. These regularities are revealed as a result of the comparison of really revealed sociometric choices, as well as the results of the use of the method of false self-esteem. Of course, this data is not enough for a deep analysis of the nature of expectations about the evaluative attitude of the broader social environment.

Research conducted previously on the psychological features of depressed adolescents (I.P. Bashkatov ${ }^{29,30,31}$, G.G. Bochkareva, 1968,

\footnotetext{
29 Башкатов И.П., Фицула М.Н. Основы исправления и перевоспитания несовершеннолетних осужденных в воспитательно-трудовых колониях. М.:ОВТК ГУИТУ - 1984. 324 с.

30 Башкатов И.П. Социально-психологические особенности развития криминогенных групп подростков // Психология и профилактика асоциального поведения несовершеннолетних. Тюмень: ТГУ, 1985. - C. $15-26$.

31 Башкатов И.П. Психология групп несовершеннолетних правонарушителей: Социальнопсихологические особенности (Монография). М.: Прометей, 1993. - 312 с.
} 
E.I. Dranishcheva, 1972, M.U. Kondratiev ${ }^{32}$, etc.) have shown that the regime closure of an institution in which a young man is a teenager can not but generate the specifications of personal development. The narrowing of the channels of communication with the broad society creates a rigid formation of an intra-group hierarchy. The secrecy of the group puts it in a situation of opposition to society, depending on belonging to a particular social environment, although the group does not set similar tasks. Depressed teenagers confront the social environment, but do not want to agree with the view that they are qualitatively "worse" children, from another social reality. They are characterized by a willingness to accept and respond to the favorable attitude of the social environment from both peers and adults.

Thus, it can be concluded that prolonged group isolation in certain circumstances is characterized by the loss of certain mental bonds, isolation of the usual, needy, complication of the psychological content of the activity.

The study examined the questions about: 1) how the self-esteem of the boarding school and penitentiary institution differs in the situation of forced assessment confrontation; 2) what is the awareness of the evaluative attitude towards themselves from the other social environment among the graduates of institutions of different degree of regime, 3) what is the nature of the orientation of the processes of "I-confrontation" and "I-identification".

The study used the results of a survey of adolescents sentenced to imprisonment of prisoners (50 male adolescents aged 14 to 17 years) and boarding schools for orphans and children deprived of parental care (49 male adolescents over 14 years of age). To obtain a more complete picture of the processes of self-confrontation and self-identification, the technique of comparing oneself to a quasigroup was used.

The tasks identified in the study aim to give special attention to the structure of ranks in such groups under conditions of forced isolation.

In order to obtain the empirical material needed to illuminate the answers to the questions we were interested in, a sociometric technique was used according to functional criteria, as well as a modified technique of "false self-assessment".

12. Кондратьев М. Ю. Социальная психология закрытых образовательных учреждений. СПб.: Питер, 2005 - 304 с. 
The first technique revealed the status positions in both contingent samples and the intragroup structure of the two groups studied. A group of adolescents in a penitentiary institution built relationships by the type of monostructure, that is, they showed in all spheres of group activity a situation of invariance of the status hierarchy, which implies the attachment of low or high status always to the same members of the group. The orphanage students demonstrated the presence of a large number of different rank structures in each area of group activity, indicating group formation by type of polystructure.

The modified version of the methodology of "false self-assessment showed the orientation of the processes of "I-identification" of "I-confrontation" in the situation of forced comparison of myself with peers. The subjects were offered a questionnaire for self-assessment, where 12 characteristics were determined, half of which were conditionally classified as socially approved, and half had relatively negative content: self-esteem, self-confidence, kindness, justice, sociability, modesty, modesty, aggressiveness, light-heartedness, aggressiveness, vigilance, passivity.

Recall that the results were obtained by presenting to each member of the groups of boarding school students and the penitentiary institution their own self-assessment under the guise of a self-assessment form filled out by the graduates of another type of institution, in terms of their institutional closure. Carrying out a similar procedure made it possible to see that the students of the boarding school, initially, are in a more favorable position and their positions are socially supported. Therefore, they act from the standpoint of society, as individuals with a sociallyapproved form of behavior unlike the graduates of the penitentiary department.

Seeing themselves in a more favorable light about the broader social environment compared to their peers from the educational institutions of the penitentiary system, the students of boarding school raise their own self-esteem in the situation of comparing themselves with them, clearly confronting with indicators of the quasi-group and convicting themselves self-esteem indicators.

A special place is occupied by low-status boarding school students, who tend to identify themselves with the students of the educational colony. 
The positions of "average" in both samples were statistically indistinguishable.

Indicators for adolescents in the penitentiary system were different. Despite their increased willingness to receive a favorable evaluation from the side, adolescents in a penitentiary do not have a particular sympathy for those deprived of parental care and prefer to identify with the same as themselves. This, underscores the objectively existing fact of the disadvantaged position of the graduates of the closed institutions among the representatives of the society outside the penitentiary institution.

The prejudiced attitude of "family" peers from penitentiary institutions, educators and society in general is expressed in the absence of a favorable attitude towards orphans and the presence of a negative attitude given by the stereotypical view of this contingent of subjects in ordinary consciousness.

In general, our assumption about the status determination of the dynamics of self-esteem has been confirmed in the process of its verification by experiment.

The result of the procedure is a "new" self-assessment, which is determined by the features of the stimulus material, which before the second series was presented to the subject. We mean the information that characterizes the "other" who is credited with the authorship of the completed form under the experimental conditions. The magnitude and direction of the change in self-esteem are conditioned by what the test taker considers to be the received form with his or her own self-esteem portrait.

The use of this procedure in other studies and for solving other problems has revealed some patterns of self-esteem dynamics or its stability

a) stability of self-esteem is conditioned by presentation of the subject's own self-esteem under the guise of self-esteem of a significant or authoritative person for him;

b) "shift" in the assessment of one's personal characteristics is most noticeable if the subject is informed that the form presented to him is filled with a negative reference for him, that is, his opinion for the subject is very important, but he treats this person with deep dislike;

c) is submitted under the guise of self-assessment of a member of the group, which is clearly different from the subject in terms of status, physical strength, etc. 
Consequently, the technique of false self-assessment allows not only to determine the degree of expressive influence of another person on the person of interest, but also gives the possibility of the most effective way of educational influence, selection and design of corrective programs. Such specificity of the result requires a particularly careful interpretation of the empirical data.

Given that at the threshold of adolescence there is a crisis of self-esteem, which is accompanied by an update of the need for self-affirmation, then the specific conditions of communication that develop in institutionally closed educational institutions, the lack of emotional well-being often lead to the formation of conflict situations. And the inability of self-affirmation of adolescents brought up in closed institutions in various spheres of activity, as a rule, leads to the emergence of ugly forms of individualization, such as malicious negativism, cynicism, cluelessness, abandonment of various activities and others.

\section{CONCLUSIONS}

To sum up, it should be concluded that the broad society in Ukraine has long been formed under the influence of unlimited power of the state, state institutions of subordination and violence, and in the sphere of education and upbringing under the influence of the priority of logocracy and punishment. The society has long favored predetermination and total control, and in the current conditions of social transformation of society there is a need to develop such social institutions that could reconcile both the interests of the state and the private values and interests of the people, it is necessary to promote the development of mechanisms of autonomy of private life.

Penitentiary systems partly act as a diminished model of a sociable congruence and possess all the hallmarks of socializing influence, especially when it concerns adolescents. The inability to self-affirm adolescents brought up in closed institutions or its restriction, as a rule, leads to the emergence of ugly forms of individualization, such as malicious negativism, cynicism, expletive behavior, rejection of various activities and other destructive forms of behavior.

The specific conditions of communication that develop in closed educational institutions of varying degrees of incarceration (boarding school, educational colony), lack of emotional well-being often lead to the formation of conflicting unstable self-esteem and the emergence of situational and personal anxiety. 
Adolescents who are in a penitentiary institution do not have much sympathy for those deprived of parental custody and prefer to identify with the same as themselves. This, underscores the objectively existing fact of the unfavorable position of the graduates of closed institutions among the representatives of the society outside the penitentiary institution.

A positive or negative "shift" in the assessment of one's personal characteristics depends on the recognition of a positive or negative attitude in the society towards a group, a member of the group to which he or she is in a confrontation.

It was found that there is a definite relationship between the degree of regime, closedness, the priority of the prescribed behavior of the educational institution and the characteristics of grouping, interpersonal perception in really functioning groups of adolescents. These processes generally follow the same pattern as in a juvenile detention facility, but the specific form of manifestation of group formation and group structure has their specificity.

\section{SUMMARY}

The publication reveals some aspects of the life of a person and a group of minors in prison systems, which, to a certain extent, can act as a reduced model of a sociable congruence. The problem of group formation in conditions of forced relative isolation of a group in relation to minors, from the standpoint of social psychology, is considered.

The socio-psychological features of intergroup and intragroup interaction in adolescent groups and its social-perceptual aspect have been determined; peculiarities of intragroup structure of real groups under conditions of penitentiary institution are studied.

There is a description of the connection between the degree of regime, closedness, priority of the prescribed behavior of the educational institution and features of grouping, interpersonal perception in really functioning groups of adolescents.

It is established that these processes as a whole proceed according to the same scheme as in the conditions of an adult penitentiary institution, but the specific form of manifestation of group formation and group structure has their specificity in them.

It can be described as a problem related to group formation in conditions of forced relative localization and isolation of the group in relation to a certain contingent, a specific type of joint activity, to a certain 
age, gender, from the standpoint of not only general, age and pedagogical, but also social psychology.

On this basis, it is necessary to determine the socio-psychological aspects of intergroup and intgroup interaction in adolescent groups, its social-perceptual aspect; to study peculiarities of intragroup structure of real groups in conditions of penitentiary institution.

The publication reveals some aspects of the life of a person and a group of minors in prison systems, which, to a certain extent, can act as a reduced model of a sociable congruence. The problem of group formation in conditions of forced relative isolation of a group in relation to minors, from the standpoint of social psychology, is considered.

The socio-psychological features of intergroup and intragroup interaction in adolescent groups and its social-perceptual aspect have been determined; peculiarities of intragroup structure of real groups under conditions of penitentiary institution are studied.

There is a description of the connection between the degree of regime, closedness, priority of the prescribed behavior of the educational institution and features of grouping, interpersonal perception in really functioning groups of adolescents.

It is established that these processes as a whole proceed according to the same scheme as in the conditions of an adult penitentiary institution, but the specific form of manifestation of group formation and group structure has their specificity in them

\section{REFERENCES}

1. Андреева Г.М. Социальная психология. М.: Аспект-Пресс. 2000. С. 186-190, 274-288.

2. Асмолов А.Г. Психология личности: культурно-историческое понимание развитие человека (3-е изд. Испр и доп.). - М., Академия, Смысл, 2007. - 528 с.

3. Багрецов С.А. и др. Диагностика социально - психологических характеристик малих груп. - СПб.: Питер,1999. - 638 с.

4. Башкатов И.П., Фицула М.Н. Основы исправления и перевоспитания несовершеннолетних осужденных в воспитательнотрудовых колониях. М.:ОВТК ГУИТУ - 1984. 324 с.

5. Башкатов И.П. Социально-психологические особенности развития криминогенных групп подростков // Психология и 
профилактика асоциального поведения несовершеннолетних. Тюмень: ТГУ, 1985. - С. 15-26.

6. Башкатов И.П. Психология групп несовершеннолетних правонарушителей: Социально-психологические особенности (Монография). М.: Прометей, 1993. - 312 с.

7. Бєлавіна T.I. Міжособистісні відносини в умовах соціальної депривації // Соціально - психологічний вимір демократичних перетворень в Україні / За ред. Максименка С.Д., Циби В.Т., Шайгородського Ю.Ж. та ін. - К.: Український центр політичного менеджменту, 2003. - С. 357-369.

8. Бехтерев, В.М. Основные задачи рефлексологии физического труда [Текст] / В.М. Бехтерев // Вопросы изучения и воспитания личности. - 1919. - № 1. - С. 51.

9. Беца О. Соціальна адаптація осіб, звільнених із місць позбавлення волі // Соціальна політика і соціальна робота, 2002. № 2. - С. 5-15.

10. Зиммель Г. Социальная дифференциация: Социологические и психологические исследования / Г. Зиммель // Избран. в 2 т: Т. 2 : Созерцание жизни. - М: Юрист. - 1996. - 164 с.

11. Кули Ч. Человеческая природа и социальный порядок : [Науч. изд.] : пер. с англ. / Ч. Кули М. : Идея-Пресс : Дом интеллектуальной книги, 2000. - 309 с.

12. Кондратьев М.Ю. Социальная психология закрытых образовательных учреждений. - СПб.: Питер, 2005 - 304 с.

13. Левин К. Теория поля в социальных науках / [Пер. Е. Сурпина]. - СПб.: Речь, 2000. - 368 с.

14. Морено Я.Л. Социометрия: Экспериментальный метод и наука об обществе / Пер. с англ. А. Боковикова. - М. :Академический проект, 2001. - $320 \mathrm{c}$.

15. Олейник А.Н. Тюремна субкультура в Росії: від повсякденного життя до державної влади. - М.:ИНФРА - М., 2001, $\mathrm{X} 1 \mathrm{Y}, 418 \mathrm{c}$.

16. Олпорт Г. Становление личности: Избранные труды / [Пер. с англ. Л.В. Трубицыной и Д.А. Леонтьева]; под общ. ред. Д.А. Леонтьева. М.: Смысл, 2002. - 462 с.

17. Петровский А.В. Психология развивающейся личности: монография. М.: Педагогика, 1987. - 240 с. 
18. Пирожков В.Ф. Криминальная психология. - М.: «Ось-89», 2007. - 704 c.

19. Пономарев, С.Б. Синдром тюремной социальной депривации в молодом возрасте / С.Б. Пономарев и др. - Екатеринбург, 2008. -27 с.

20. Психологія групової ідентичності: закономірності становлення: [монографія] / [П.П. Горностай, О.А. Ліщинська, Л.Г. Чорна та ін.] ; за наук. ред. П.П. Горностая. - К. : Міленіум, 2014. - 252 с.

21. Синьов В.М., Кривуша В.I. Пенітенціарна педагогіка: в запитаннях і відповідях: [Навчальний посібник] / В.М. Синьов, B.I. Кривуша,. - К: ПМ Леся, 2002. - 123 с.

22. Соціальна робота 3 неповнолітніми, які перебувають у місцях позбавлення волі.// За ред. Синьова В.М. - К., 2003. - 222 с.

23. Тард Г. Социальные законы Пер. с фр. Изд. 2-е. - М.: Книжный дом «ЛИБРОКОМ», 2009. - 64 с.

24. Хрящова, Н.Ю. Психические состояния при изоляции / Н.Ю. Хрящова. - СПб.: Питер, 2000. - 413 с.

25. Шевченко Л.А. Личность преступника в гендерном измерении // Личность, семья и общество: вопросы педагогики и психологии: сб. ст. по матер. LXXI междунар. науч.-практ. конф. № 12 (69). - Новосибирск: СибАК, 2016. - С. 33-41.

26. Moede W. Experimentelle Massenpsychologie. Beitrage zur Experimentalpsychologie der Gruppe. - Leipzig: Hirzel, 1920. - 239 p.

27. Festinger, L. Wish, expectation and group standards as factors influencing level of aspiration // Journal of Abnormal and Social Psychology, 1942, 37 (2), 184-200.

\section{Information about the author: Bielavina T. I. $\mathrm{PhD}$ in Psychology,} Associate Professor at the Department of Psychology and Pedagogy of the Scientific and Humanitarian Institute of the V. I. Vernadsky Taurida National University 33, Ivana Kydri str., Kyiv, 01042, Ukraine 


\section{PSYCHOLOGICAL AND PEDAGOGICAL SUPPORT FOR THE DEVELOPMENT OF CREATIVE CAPABILITIES IN THE CHILDHOOD PERIOD}

\section{Bila I. N.}

\section{INTRODUCTION}

The researcher of children's creativity E.V. Subotskyi stated that "the creative, intellectual and moral capabilities of a child are inexhaustible. It is unlikely that today they are used for one hundredth part. To reveal and realize them is an incredibly difficult task. In other words, we live above the deposits of precious "minerals" of the psychics, most often not even suspecting them" . It is important to find out the "personal code" of each child and select the "keys" to the development of his or her talents precisely during their formation.

The raised problem of identifying the abilities of children in preschool age and providing favourable conditions for personal formation, creative self-realization of a child, the formation of an active-cognitive, creative attitude to the real world in a pre-schooler, the ability to orientate successfully in a wide variety of objects and phenomena, arming with methods of creative cognitive activity can be solved by analysing effective diagnostic tools and activating creative abilities at the childhood stage.

The decisive step in solving the tasks set may be the construction of a theoretical and structural model of the development of capabilities, which takes into account the integrative, multidimensional structure of capabilities and the laws of their ontogenesis, which are manifested in the individual characteristics of the course of mental processes and personality formations in certain types of activities. The model is a guideline for determining the criteria for assessing the development of various types of capabilities, their growth vector in the developing space conditions.

\footnotetext{
${ }^{1}$ Subbotskiy S.V. The child opens the world / S.V. Subbotskiy - M.: Prosveshcheniye, 1991. - 207 p.
} 


\section{A structural model for studying the basic characteristics of a child's capabilities}

Let us emphasize that childhood is a period of formation of a child's psychics, the emergence of particularly favourable prerequisites for the flowering of his or her individual creative capabilities and giftedness, etc. That is why it is so important to ensure at this age the diversified development of all the talents and possibilities for manifesting the child's personality. This is possible only if adults take into account the child's individual peculiarities, characteristics and favourable conditions for the formation and development of children's talents.

Well-known psychologists and teachers (L.S. Vygotskyi, V.A. Krutetskyi, V.T. Kudryavtsev, O.I. Kulchytska, M.M. Poddyakov, B.M. Teplov and others) proved that capabilities are vividly manifested in the childhood and gradually develop in the process of specially organized training. The construction of a model, a project-study scheme, the development of capabilities and the awareness of adults raising children about the specifics and patterns of their manifestation will accelerate the success of the growth of the capabilities, the formation of a creative and harmonious personality.

We chose the ideas of scientists as the theoretical basis for the development of the model (P.Ya. Galperin, D.B. Elkonin, V.V. Davydov, O.M. Leontyev, S.L. Rubinshtein, B.M. Teplov and others) regarding the dynamic essence of the capabilities, the determining factors of their development, in particular, upbringing and training and interaction with the social environment. The human's capabilities, in their opinion, are the internal conditions for his development, which are formed under the influence of the external conditions in the process of interaction with the world. "The practical limits of the development of the capabilities are determined only by such factors as the length of a human life, the conditions of this life, the methods of education and training, etc., but are not at all embedded in the capabilities themselves. It is enough to improve the methods of education and training so that the limits of the development of the capabilities immediately expand" (B.M. Teplov, 1961). According to S.L. Rubinstein, the development of capabilities is done in a spiral: "... the realization of a capability, which represents a capability of one level, opens up new possibilities for the further development of the capabilities of a higher level. The composition of each capability which 
makes a person capable of performing certain activities always includes some operations or modes of action by which this activity is carried out. No capability is an actual, real capability, until it organically absorbs the system of relevant socially developed operations (S.L. Rubinstein, 1960) ${ }^{2}$.

O.M. Leontyev, developing the ideas of L.S. Vygotskyi, justifies the "historical inheritance of capabilities": instruments of production and products of labour are the embodiment of human capabilities. He also claims that a person has only one ability - the ability to develop, and abilities are formed in the process of assimilation by each generation of people of what was created by previous generations, thereby historically inheriting the capabilities of previous generations. This process in each generation opens up new opportunities for their development compared to previous generations ${ }^{3}$.

In the composition of capabilities, the motivational, value-based, and cognitive components are important. Motivation, interest, individual values and knowledge determine the qualitative specificity of capabilities, the specificity of solving cognitive tasks by an individual depends on them.

Each type of creative activity is characterized by a psychologically unique composition of capabilities, individual differences, manifested both in the general level of giftedness and in the qualitative originality of individual cognitive processes, in their structural interrelation.

According to V.O. Krutetskyi, the integrative nature of capabilities manifests itself in the individual characteristics of the course of mental processes (attention, perception, imagination, thinking, memory) and personality formations (orientation of relationships and emotionalvolitional elements) in certain types of activity. Therefore, capabilities can be classified by psychological, personal criteria such as: sensorimotor, perceptual, mnemonic, imaginative, thinking, communicative, motivational, emotional and volitional, etc., as well as by the criteria of attribution to a specific subject area - scientific (humanitarian, linguistic, mathematical, engineering), artistic (literary, musical, visual) and more. Capabilities are also subdivided into common ones that are found in most activities (mental, physical, academic) and special, narrow, limited by

\footnotetext{
${ }^{2}$ Rubinstein S. L. The problem of capabilities and questions of psychological theory // Psychology of individual differences / ed. by Yu.B. Gippenreiter, V.Ya. Romanova. - 3-rd ed., revised and accomplished - M.: AST: Astrel, 2008. - P. 47-54.

${ }^{3}$ Losyeva A. A. Psychological diagnosis of giftedness: a textbook for high schools / A.A. Losyeva. - M.: Academic Project: Triksta, 2004. - 176 p.
} 
subjects of these activities (technical, operator, pedagogical, managerial, musical, literary, mathematical $)^{4}$.

V.D. Shadrikov proposed the division of capabilities into creative and performing, which reflects the essential differences between the creative and conservative personality type. The author emphasizes that normative (performing) capabilities are a necessary stage in the development of others, which should provide the conditions for a qualitative leap from performance to creativity ${ }^{5}$.

Therefore, capabilities are developed on the basis of integration components, personality traits, in conditions of direct interaction of an individual with society. The interconnection of these components, external and internal conditions for the development of capabilities is the starting point and theoretical basis for solving the fundamental debatable issues of the theory of capabilities, developing a model and experimental tools for their analysis.

Currently the presented analysis of the scientific theories gives us grounds for the construction of such a theoretical and structural model of development of capabilities (Fig. 1), which takes into account the integrative, multidimensional structure of capabilities and patterns of their ontogenesis, which are manifested in individual features of the course of mental processes (attention, perception, imagination, thinking, memory) and personal formations (the focus of attitude, emotional and value-based, volitional elements) in certain kinds of activities. The constructed model is the basis for determining the criteria for assessing the development of different types of capabilities and their growth vector.

It should be emphasized that the most effective diagnostic method of studying the capabilities at preschool age is the observation of a child in various activities and recording life observations. The advantages of the observation method are that it takes place in natural, child-friendly surroundings, at home, in an educational establishment where the effects of the restrictions imposed by standardized tests are unaffected.

The most efficient method of studying interests, inclinations and abilities, from an early age, is observation. During the observation of the child's play, his or her behaviour in different activities, an adult observes

\footnotetext{
${ }_{5}^{4}$ Platonov K.K. Problems of capabilities / K.K. Platonov. - M., Nauka, 1972. - 312 p.

Shadrikov V.D. Psychology of capabilities // Psychology of individual differences / ed. by Yu.B. Gippenreiter, V.Ya. Romanova. - 3-rd ed., revised. and accomplished. - M.: AST: Astrel, 2008. p. 64-79. - (Reading book on Psychology).
} 
the individual features of capabilities manifestation, generally determines the type of activity that the child prefers in the situation of choice, that is, he allots most of the time and enjoys the greatest pleasure, etc.

A successful attempt is for an adult to keep a creative diary of a child, where the results of observations of his or her creative activity are noted, interests and capabilities are recorded in the course of games and selfactivity, as well as the results and achievements of his or her successful productive activity.

Widely used in development work are the data obtained in the course of studying the products of children's activities, conducting conversations, and using the methodology of incomplete sentences, etc. So, for example, the child is suggested to continue a saying like: "Most of all I like to do...", "In the future I dream of becoming...", "I want the wizard...", etc.

It will be appropriate to use practical methods of studying subjective preferences, which have been known in the East since ancient times. So, the intuitive subjectivization of a baby's choice can be observed if at the age of 1 to 3 years you put in front of him a book, money, a hammer and a weapon. Left alone, the child makes a choice that is made so far unconsciously, but quite projectively. For example:

- The child chooses the object of work - he wants to do everything himself. It can be predicted that his leading quality in the future will be hard work;

- The child chose a weapon - he likes to control, play war. A child will grow into a leader who has a strongly pronounced desire to protect the weak;

- The child preferred the book. The kid showed a desire to engage in scientific or literary activities, and for the time being enjoys listening and reading. For such children, the most important thing is to understand the content. Their main feature is honesty;

- A small hand which reached for the bill reveals the character of a person inclined to engage in trade, business and economic activity. The main feature is generosity and a simultaneous desire to be rich ${ }^{6}$.

The episodes from the life of children from the tales of parents, educators, and other adults involved in the upbringing can provide fairly comprehensive information about the child's developmental history and the interests of the child. All this is of particular importance given that the traditional testing conditions do not give researchers sufficient time to

\footnotetext{
${ }^{6}$ Bila I.M. Psychology of children's creativity / I.M. Bila. - Kyiv., Phoenix, 2014. -200 p.
} 
monitor the child, and this forces them to focus on the results of the implementation of specially proposed tasks. The observations are also valuable because they help to identify especially rare capabilities that may be missed during the examination of the child. If the child is monitored systematically for a certain period, the results make up a map (portrait) of the child's development, which is difficult to obtain with the help of tests.

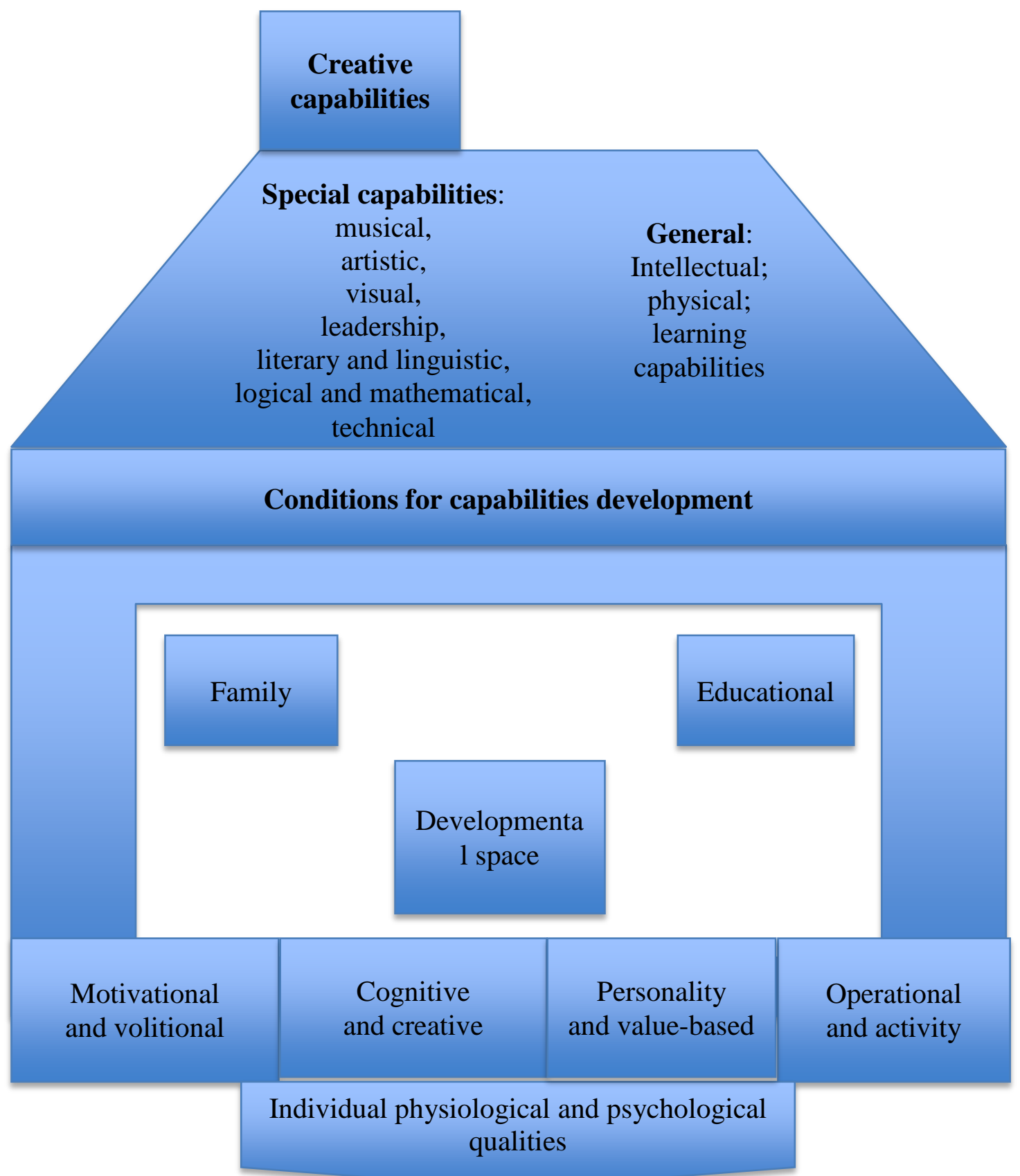

Fig. 1. Structural model of capabilities development 
Observing the success of children in a certain type of activity, adults can also notice the achievements that go beyond the age norms. They themselves are an indicator of giftedness. If a child is very pleased to engage in a certain type of activity and is almost indifferent to others, we can state that she has certain capabilities.

General intellectual abilities are manifested in the ease of learning, observation, acumen, mobility, speed of thinking, exceptional memory, rich and diverse awareness of the child. An intellectually gifted child thinks well, thinks clearly, asks many questions, is observant, has a creative perception and quickly responds to everything new.

Language skills are manifested in the child's unusual interest in reading, which becomes a favourite activity, in preserving and lasting attention to the book, verbal information, a good understanding of what the child is reading, memorizing and reproducing the read.

The capabilities in mathematics are manifested in the interest in calculating, measuring or organizing objects, in an unusual understanding of mathematical symbols for their age; the capabilities in natural science in an exceptional interest in the living nature, natural phenomena, inclination to their classification, in the interest in natural experiments, in understanding causal relationships in nature, and the like.

Communication and leadership are characterized by a high level of communication, easy adaptation to different situations. In front of strangers, the child retains self-confidence, easily communicates with adults and children, generates ideas and takes initiative. The child often becomes a leader in joint activities, assumes the role of organizer, and has the gift of conviction. Other children contact him or her for help or advice.

The artistic and visual capabilities of the child are manifested in interest in visual information. He remembers what he saw in detail. He draws and sculpts a lot of time, is working intensely on his works, and originally uses materials of artistic expressiveness. Building the composition of a drawing, he includes many details in it. There is no monotony in the images of an artistically gifted child; he reproduces in visual activity everything that he sees around.

Psychomotor capabilities are manifested in high interest in activities that require effort of fine motor skills. The child has good visual-motor coordination, loves to run, jump, has excellent balance when performing 
movements, exercises control over his body in any manoeuvring, has considerable physical strength in relation to his age.

If a child has an interest in music, singing, he is sensitive to the nature and mood of the music, composes his own original tunes or sings - he has musical capabilities and they are worth developing.

The child manifests independence and nonconformity, inventiveness in his productive activities, considerable flexibility in solving problems or using materials, can produce original ideas and find a new approach in standard situations, is interested in different mechanisms and machines, designs and projects a lot - he or she has the potential of technical creativity.

A child may be inclined to fantasize when he or she talks about something familiar, originally conveys the character, feelings, mood of the characters, easily builds storylines and prefers reading - then he or she is prone to literary creativity.

Children with artistic capabilities are easily involved in the role of any character, convey feelings and emotions through facial expressions, gestures, movements and like dramatization games ${ }^{7}$.

It is worth noting that the pace, ease of assimilation and the speed of advancement in a particular area can serve as a significant indicator of the development of capabilities. But it is necessary to take into account the results or the speed of development in relation to its conditions, because the same achievements in study or activity under different conditions may indicate unequal capabilities. The ability to achieve great achievements under externally difficult, disadvantageous conditions indicates particularly great capabilities.

In addition, it is important to analyse the creative potential of the child, which is an internal prerequisite for the development of capabilities, the core of talent. Creative potential includes:

- makings, inclinations, which are manifested in hypersensitivity, given selectivity, preferences, as well as in the dynamics of psychological processes;

- interests, their orientation, frequency and systematic manifestations, dominance of cognitive interests;

- curiosity, desire to create new things, inclination to solve and find problems;

\footnotetext{
${ }^{7}$ Bila I.M. Psychology of children's creativity / I.M. Bila. - Kyiv., Phoenix, 2014. - 200 p.
} 
- speed of assimilation of new information, creation of associative arrays, inclination to constant comparisons, development of standards for subsequent selection of information;

- displays of general intelligence - understanding, speed of assessment, choice of ways of solution, adequacy of actions;

- emotional coloration of the cognition processes;

- emotional attitude, influence of feelings on the process of subjective evaluation;

- persistence, commitment, determination, hard work, systematicity in work, courage in decision-making;

- creativeness - the ability to combine, find analogues, reconstruct, an inclination to options replacement, cost-effectiveness of decisions, rational use of means, time, etc.;

- intuitivism - the ability to quick assessments, decisions, forecasts;

- an inclination to build personal strategies and tactics when solving general and special new problems, tasks, finding a way out of complex, non-standard situations, etc. ${ }^{8}$.

An effective diagnostic tool in determining subjective inclinations in both childhood and adulthood is also a whole battery of projective techniques that have common properties. It is believed that when operating with uncertain material (for example, obscure pictures, or ink spots of a vague configuration, as in the Rorschach test), the subject projects the features of his inner world onto it. Having received the task to arbitrarily draw geometric shapes, draw a picture, etc., the child offers exactly the option that testifies to the features of his or her personal composition.

An efficient method of studying abilities and interests, starting from the senior preschool age, is self-analysis, introspection. In assessing the results of his activities, the child analyses his interests and abilities, determines the scope of major achievements, personal accomplishments and successes.

As for the factors that stimulate the formation of capabilities at the beginning of ontogenesis, primarily they are the following: providing a favourable atmosphere, a positive psychological climate, opportunities for exercise and practice; aesthetics of the developing environment; enrichment of the environment with a variety of new objects and

\footnotetext{
${ }^{8}$ Bila I.M. Psychology of children's creativity / I.M. Bila. - Kyiv., Phoenix, 2014. - 200 p.
} 
incentives; attracting literature and art which contributes to the formation of aesthetic criteria for a gifted personality; the wide use of divergent type questions, encouraging the expression of original ideas; refusal to express evaluations and criticism of the child; personal example of creative adult behaviour; the interaction of all participants in the pedagogical process; pedagogical skills of an adult in identifying and developing the abilities of a child. We will analyse in more detail the prerequisites for the formation of the capabilities in the next paragraph.

At the moment it should be borne in mind that the perception of a child by adults can be distorted by emotional factors, ignorance of age norms of development, incorrect evidence received from friends or even specialists. Taking into account the lack of operational and universal means of verifying the authenticity of life observations, the experimenter has to compare them with other objectively established data (test results, questionnaires, products of children's creativity, specialists' verified information, etc.) and the results obtained by the methodology proposed by us.

In the preparation of diagnostic tools, methods of studying the children's capabilities, we took into account the structural model of capabilities development designed by us (Fig. 1) and modified according to it the scale of rating of the capabilities basic characteristics of J.Renzulli, existing in experimental practice. We compiled the scales of the basic characteristics of the methodology for studying the capabilities of children in such a way that an adult raising a child could evaluate the characteristics that we highlighted in cognitive, motivational and volitional, creative, personal-value and operational areas in points from 1 to 4 . It is important to determine each of the points on the scale without reference to other points. The assessment should reflect how often adults observe in a child the manifestation of each of the characteristics. The assessments on different scales are not added up.

The study instructions were formulated, namely: "Read carefully the statement and put $\mathrm{X}$ in the appropriate place according to the following criteria: 1 - if you almost never observed this characteristic in a child; 2 - if you observe this characteristic from time to time; 3 - if you observe this characteristic quite often; 4 - if you constantly observe this characteristic".

The scales highlighted according to the model, include the following characteristics: 


\section{Scale I. Cognitive characteristics:}

- has an unusually large vocabulary for his age, uses terms with comprehension, language is distinct, easy and complex;

- has an extensive stock of information on a variety of topics (which go beyond the ordinary interests of children of this age);

- quickly memorizes and reproduces factual information;

- easily assimilates causal relationships; trying to understand "how" and "why"; asks a lot of questions stimulating the thought (as opposed to questions aimed at obtaining facts); wants to know what underlies the phenomena and behaviour of people;

- a sensitive and quick-witted observer; usually "sees more" or interprets more broadly what he sees, sees, reads and what happens compared to others.

\section{Scale II. Motivational and volitional characteristics:}

- demonstrates enthusiasm and activity;

- manifests good organization and diligence in the process of his favourite activities;

- feels confident in the area of his interests;

- brings his favourite business to an end;

- shows leadership abilities in the field of his competence. With pleasure shares with others what he knows and can do.

\section{Scale III. Personality and value-based characteristics:}

- consciously chooses the field of activity, cognition or personal relationships;

- demonstrates a selective preference for certain sides of reality, a certain content, a way of performing experimental tasks, and his attitude towards them;

- realizes himself, his qualities, how they are judged by others, his evaluations of others, the areas of the reality and the preferred activities;

- immersed in the situation, captured by it and leans on its previous experience;

- expresses confidently his thoughts, beliefs, interests and puts them into practice.

\section{Scale IV. Creative characteristics:}

- puts forward a large number of ideas or solutions to problems and answers to questions; offers unusual, original, reasonable answers;

- expresses fine sense of humour and sees humour in situations that don't seem ridiculous to others; 
- inclination to play with ideas; fantasizes, imagines: I wonder what happens if...; engaged in the adaptation, refinement and alteration of objects and systems;

- extremely sensitive to internal impulses and more open to the irrational in himself;

- sensitive to beauty, paying attention to the aesthetic component, is interested in details. He or she is not afraid to be different than everyone.

\section{Scale V. Operational characteristics:}

- has experience and knowledge in the chosen field;

- performs special tasks faster than others;

- acts confidently and carefully;

- strives for excellence in the field of his interests;

- masterfully possesses practical skills of favourite activity.

After evaluating each of the characteristics, it is necessary to calculate the total number for each of the columns, multiply by the corresponding number (score) and add the numbers obtained. The general indicator shows the rating, degree of manifestation, level of development of one or another characteristic of the child's capabilities.

Let us emphasize that the study of the characteristics of children's capabilities does not only diagnose the maturity of their basic components, but also focuses on their growth. In general, the capabilities identification procedure involves a qualitative analysis of all areas of a child's activities and should take the form of psychological and pedagogical monitoring (observation, analysis of activity products, keeping a diary, the use of projective methodologies, expert assessment methods, the scale of rating of a child's abilities basic characteristics, questionnaires for parents and etc.).

Studying the capabilities of children, it is advisable to rely on the principle of humanity, individuality and the "presumption of giftedness". We emphasize that the proposed diagnostic procedure, which includes analysis methods, meets all the requirements of psychological practice and creates opportunities for a thorough study of the ontogenesis of capabilities, their foundations, starting from childhood.

\section{Prerequisites for becoming a creative personality in a developing space}

The development of intellectual and creative potentialities of children is an important characteristic of preschool, primary school age, a period of intense and independent creativity of children. All this happens naturally 
and spontaneously, but it is important to find out the most important conditions for talent formation. As a rule, gifted children do not need targeted interventions, influences and formations, and all because "to teach an intelligent one is only to harm". According to scientists, education should come out of the natural organic development of truth from the primitive consciousness of the child; it should not give ready-made truths obtained by mankind, but develop his or her own truth.

For a long time in the countries of the West and East, the testing of intellectual abilities and other types of talents was admired. The society hoped that with the help of the data obtained it would be possible to identify gifted children early and with the help of special programs and well-trained teachers to "grow up" geniuses and talented people. A decade later, it became clear that nothing would come of it. For example, several generations of Japanese were selected in childhood by the criterion of giftedness for elite education, but none of them, admittedly, became a talented adult. Conversely, almost all known talents in childhood were often outcasts.

The data of the Japanese researchers are supported by examples from the lives of famous people from different countries. Vitaliy Bianchi, a well-known children's writer having hardly reached the upper classes of the classical gymnasium at the Institute of History and Philosophy, completely refused to study. His father had to transfer the boy to a private gymnasium, where he became interested in literature, but still ignored mathematics, sitting at the last desk and writing poetry. France's most famous man, named "Man № 1, ocean explorer of the twentieth century", Jean-Yves Cousteau, was expelled from school for breaking multiple windows. This did not prevent him from becoming a talented oceanographer, scientist and writer. O.V. Suvorov's parents did not even think that their son, who was lagging behind in physical development and was a sick boy, could become a military man. And it was out of question that a prominent commander could grow out of him ${ }^{9}$.

Scientists agree that intelligence, creative capabilities are determined by heredity no more than for 30-50\%. In most examples of a talent development, it is difficult to separate the heredity factor from early training. It is clear that children with signs of giftedness in the family are

\footnotetext{
${ }^{9}$ Lobodina S.V. How to develop a child's capabilities / S.V. Lobodina - St. Petersburg: Glagol dobro, Azbuka-Atikus, 2011. -320 p.
} 
constantly in a specific environment, they are more sensitive to influences that ensure their achievement in a particular area, and contribute to the effective assimilation of knowledge and skills. For example, a child born in a family of professional musicians hears music as early as in the womb, and this contributes to the development of his or her ability to recognize the pitch and rhythm.

According to many researchers, inborn capabilities are often discussed when adults show their helplessness, or pedagogical methods demonstrate their inefficiency. And yet external factors are determining, including, in addition to pedagogical systems and educational level, a family welfare, living conditions and lifestyle, social and economic conditions in the state, and even its historical heritage. That is, mental development is affected even by poor nutrition. After all, the baby brain is an organ that absorbs almost $90 \%$ of the energy in the body of a new-born, $50 \%$ - in a five-yearold child. And if this energy is taken away by some circumstance, it can have dire consequences. Even elementary iodine deficiency, as scientists estimate, lowers IQ by 12 points.

However, no child is born a genius or a fool. It all depends on the stimulation and the degree of brain development in the crucial, sensitive years of the child's life, when the adult's particular attitude to the child's creative activity may develop or slow it. Scientists prove that almost 50\% of mental capabilities are formed in a child under four years old, $80 \%$ - up to eight. "The age from birth to 6-7 years is the period when the fate of the child is decided", said Japanese violinist and teacher Sh. Suzuki. It is at an early age, depending on the conditions; the child's capabilities can be fully manifested or only marked out ${ }^{10}$.

If a child is brought up in an environment that is alien to his nature, then he has little chance to fully and completely develop in the future. In this case, it is important to what extent the opportunities of the society are consistent with the potential of the child.

Majestic pine trees that grow in the forest can serve as an example. They are not at all like their dwarf counterparts, who aspire to stay on rocky areas where there is practically no land, or their relatives, who were raised in pots by the Japanese craftsmen, regularly pruning their roots and preventing plants from getting proper nutrition. They look so much like an unfortunate Chinese princess's foot which at the age of five years is put in

\footnotetext{
${ }^{10}$ Ibuka M. After three it is already late / Masaru Ibuka. - M.: Olta, 2003. - 64 p.
} 
a block to keep a small shoe size. In all these cases, the change in form is not the result of genetic changes, but the hostility of the environment to the perception of this genotype.

The inborn inclinations of a child can be realized only in the active life of the individual, in a favourable environment, under the influence of proper education and training. Unfortunately, an artistically gifted child from the Central African tribe will never become an artist, just because he will not get paints in his hands with which he could designate his inner world [8].

Children are born with powerful individual creative potential, a resource of creative possibilities, the ability to creative actions, the ability to create. Already at a fairly early age, they also have a formed system of self-regulation, which, to a greater extent, is controlled by intuition. In the preservation of childhood and children's intuition P.A. Florenskyi saw the secret of human genius. The main task in this case should be the development of the internal cognitive and personal potential of the coming generation.

Nevertheless, in practice regrettably happens something that JeanJacques Rousseau wrote about: "Everything good which proceeds from the hands of the Creator of things, is degenerated in the hands of man. He makes the earth produce the products of another earth, a tree - produce the fruits of another tree..., he distorts everything; he loves ugliness; he does not want anything as it was created by nature, even a human; he wants to break him in, like a riding horse, to distort for fashion, like a tree in his garden"11.

In real conditions, adults impose their interests on children, preventing them from full demonstration of their capabilities, and they also lack pedagogical insight and predictability for discerning even vague outlines of future talent.

An unsuccessful example of the implementation of capabilities is described by Mark Twain. "... A man, once in the afterlife, asks to show him the best commander of all times. A great military genius, he writes, in our world was a mason named Jones. Wherever he appeared, the crowd immediately came together to look at him at least with one eye. Caesar, Hannibal, Alexander and Napoleon - all serve under his leadership, and, in addition to them, many illustrious commanders; but the people pay no attention to them when they see Jones. Everyone knows that if Jones had presented himself with a good chance, he would have demonstrated to the

\footnotetext{
${ }^{11}$ Russo J.-J. Selected writings / J.-J. Russo. - Moscow: Children's literature, 1976. - 187 p.
} 
world such talents of the commander that all the others would have seemed childish fun. But the case did not happen. Many times he tried to enlist in the army as a common soldier, the recruiting sergeant did not take him"12.

Unfortunately, such examples are not uncommon in life. A child needs an adult who is ready to see individuality, a creative personality in him and give him a violin or a brush, support the initiative, approve originality. The social factor of the development of the child's capabilities is considered to have the same significance as the factor of heredity and can fully compensate or, on the contrary, level its effect. If, for example, a new-born baby is raised in an environment that is alien to his nature, then he has no chance to fully develop in the future. The most striking example is the story of the "wolf girls" of Amala and Kamala, found in a cave near Calcutta. A lot of effort was made to restore the children's human appearance, but they were in vain. There are many examples like this. For example, in the novel "Doctor Zhivago" by B.Pasternak the daughter the main characters - incredibly gifted people - is brought up outside their influence, and as a result she does not have her parents' qualities. Therefore, it is important to remember that the child's inborn inclinations can be realized only in the active life of the individual, in a favourable environment, under the influence of proper education and upbringing ${ }^{13}$.

The attention of parents and adults is usually confined not to the talents and abilities of children in need of encouragement, but to their weaknesses, which they begin to develop to the middle level. It is reminiscent of the story of animals who decided to create a school where they were taught to fly, run, swim, dig and climb. They could not agree which subject was the most important, so they decided that the training program would be the same for everyone. The rabbit was unsurpassed in running, but he almost drowned at a swimming lesson. This struck him so much that since then he could no longer run. The eagle, of course, flew fantastically, but when he had to dig and ditch, he did not succeed, and he was sent to the class for skills correction and fixing. It took him so long that he soon unlearned to fly. The same thing happened with other animals. Now they have lost the ability to be skilled in their field and were forced to engage in activities that were unnatural to them ${ }^{14}$. The same thing happens with children when adults neglect their interests, talents and inclinations.

\footnotetext{
${ }^{12}$ Twain M. Collected Works: in 12 volumes / M. Twain - M., 1961. - Volume 11. - p. 407-409.

${ }^{13}$ Nikolayeva E.I. Psychology of children's creativity / E.I. Nikolayeva. St. Petersburg: Rech, 2006. -220 p.

14 Amstrong Thomas. Individual approach. How to grow and develop the mental abilities of your child independently / Thomas Amstrong. - Kharkov: Book club "Family Leisure Club", 2001. - 288 p.
} 
A. Saint Exupery in his famous work "The Little Prince" also writes about this: "Adults advised me not to draw, but to be more interested in geography, history, arithmetic. And so it happened that at the age of six I refused from the genius career of an artist and lost faith in myself ${ }^{\prime 15}$. Considering the above, an important slogan in working with children there will be not only the psychologist's rule: "Do no harm!", but also the biblical commandment: "Do not kill (inclinations, capabilities, what is given by nature)!"

Special and popular literature describes many cases in which a child did not show interest in studying mathematics, physics, or chemistry, and was ranked among the "lazy", "unpromising", and even "dumb" ones. But this same child, being carried away by the design of automobiles, radio devices, computer equipment or other creativity, began to feel the need to study these sciences - and not by force, but independently and eagerly studied the same chemistry, physics or mathematics ${ }^{16}$.

The development of various functional systems of a gifted child proceeds unevenly, at each age stage, some functions look more active and formed, and some are in secondary places. But time passes, and in the next age periods they are ahead of other functions, yesterday's outsiders "go ahead". Different functional systems at different ages demonstrate different degrees of maturity and perfection of the individual. Some have already formed and will only be modified in the future, while others are at the stage of active formation ${ }^{17}$.

Asynchrony in the development of capable children is quite common. It may seem that to a small child inherent are the characteristics which are inherent to several age periods at once. According to the psychologist's figurative description, a child can be eight-year-old when riding a bicycle, twelve-year-old when playing chess, fifteen-year-old when studying algebra, ten-year-old when collecting fossils and two-year-old when sharing sweets with a sister.

Children often have outstanding capabilities or talents, but at the same time show low capabilities or even incapabilities for certain aspects of learning. So, for example, in some famous people (Leonardo da Vinci,

\footnotetext{
${ }^{15}$ Antoine de Saint-Exupery. The Little Prince / Antoine de Saint-Encupery; translated from French - M.: Publishing house "Sofia", 2004. - 144 p.

${ }^{16}$ Scheblanova E.I. Unsuccessful gifted schoolchildren / E.I. Shcheblanova. - M.: BINOM. Laboratory of Knowledge, 2011. -245 p.

${ }^{17}$ Scheblanova E.I. Unsuccessful gifted schoolchildren / E.I. Shcheblanova. - M.: BINOM. Laboratory of Knowledge, 2011. -245 p.
} 
A. Einstein) dyslexia (impaired reading skills) was one of the symptoms of very high levels of visual thinking, which develops before writing occurs and is more significant and valuable than verbal intellect ${ }^{18}$.

A pedagogical effect that is premature or belated in relation to a certain period is not effective enough and adversely affects the development of personal qualities. For example, you can try to start teaching the academic drawing to a pre-schooler, but no one has succeeded in achieving significant results in this - the perceptual, analytical abilities of a child are not developed enough for this yet. And it's a completely different matter of teaching this difficult thing for teenagers. The child's capabilities are revealed as he climbs the steps of constantly changing interests and inclinations. And the more such steps a child passes, the richer and more multiple personality the person becomes as a result.

Outstanding achievements are just one of the hallmarks of childhood talent and do not guarantee creative achievements in adulthood. Talent development can be delayed and even suppressed at any age stage. For example, in the first years of a child's life, the sensitivity and intuitiveness of the right hemisphere is maintained and developed quite successfully in the family and in kindergarten. But, the closer the child's age approaches 7 years, the more attention is paid to the development of the left hemisphere (every day the amount of time allotted for singing, listening to music, dancing and sports, modelling and drawing is reduced - they are supplanted by classes in numeracy, reading and writing). From the first year of study, $90 \%$ of school time is devoted to subjects aimed at developing the left hemisphere! And as a result, artistically gifted children experience the greatest discomfort at school. The more logically and consistently the new material is explained, the more difficult it is for them to learn it.

In addition, a significant number of children do not show their abilities and capabilities in the existing education system, built mainly according to the age principle. The abilities of such children are usually called hidden, generated by a complex interweaving of various internal and external causes that impede the realization of the high potential of children in their achievements. By putting the stigma of the "ungifted" child, whose abilities are not clearly manifested, adults can kill his confidence in himself.

\footnotetext{
${ }^{18}$ Scheblanova E.I. Unsuccessful gifted schoolchildren / E.I. Shcheblanova. - M.: BINOM. Laboratory of Knowledge, 2011. - 245 p.
} 
The "ugly duckling effect" can be described as a situation where objectively valuable qualities that make it possible to achieve outstanding success in life are perceived as flaws in the early stages of personality development and cause a conflict between a gifted child and his environment. A similar thing happens in real life, parents and teachers do not pay due attention to the subtle movements of the child's soul, they lack knowledge, because of prejudice, they don't notice the outstanding potential opportunities of the child ${ }^{19}$.

Also, there are cases when minor achievements of the child are perceived by adults as a gift. Sometimes incorrectly chosen educational strategies form in a gifted child an overestimated self-esteem, while ignoring the development of his volitional efforts and other character traits important for the development of genius. And as a result, the child does not pass the trial by talent and it gradually dies. It is important to form the child's objective self-esteem, the ability to evaluate himself, his actions and the actions of others.

An interesting example of the positive influence of parental attitudes is described by French author R.Gary in the autobiographical novel "Promise at Dawn". His mother emigrated from Russia, where she was an actress. In a foreign land, she did not even try to return to her beloved profession and earned money with hard work to give education to her son. Her only consolation was the dream that her son would reach all the heights in society that are possible in France (which is now almost impossible for those born in France). She did not cease to inspire her son and speak to everyone with whom she spoke: "My son will be the French ambassador, gentleman of the Legion of Honour!" He will dress in London."

Further, the author writes: "Until now, I distinctly hear rude laughter and blush when I write these lines. I see mocking, angry, contemptuous faces - I see without hatred: these are only human faces, a common thing. Perhaps it is better to say at once for the sake of clarity that today I am the Consul General of France, a party to the Liberation, the Cavalier of the Legion of Honour. And there is no doubt: I dress in London. I cannot stand the English cut, but I have no choice",20.

\footnotetext{
${ }^{19}$ Scheblanova E.I. Unsuccessful gifted schoolchildren / E.I. Shcheblanova. - M.: BINOM. Laboratory of Knowledge, 2011. - 245 p.

${ }^{20}$ Gary R. Promise at Dawn / Romain Gary. - M.: Azbuka, 2007. - 352 p.
} 
And vice versa, unreasonable, degrading criticism and negative attitudes ("You're lump, slut, etc."), comparison of a child with other children form alarming and aggressive tendencies in his behaviour, which can be manifested in the future too. In general, scientists call various reasons that impede the realization of the children's potential. Among them are environmental factors:

- the family has very low, too variable, too rigid expectations;

- chronic absence or lack of stimulation, delayed training or vice versa training according to the program of a higher (corresponding to capabilities) difficulty level;

- the peer pressure which requires compliance with "ordinary" standards, "to be like others";

- loneliness, neglect by peers and an educational establishment.

\section{Individual factors:}

- internalized problems: depression, anxiety, perfectionism, avoidance of failure, low self-confidence;

- externalized problems: disobedience, irritability, nonconformity;

- impaired learning capabilities that are laid on performance;

- non-traditional types of capabilities that do not meet the expectations of teachers;

- defect of self-regulation: disorganization, impulsivity, attention deficit, etc.

Among objective reasons, they also incude: a low psychological level of preparation of teachers for working with children who show nonstandard behaviour and thinking; the absence of special programs, special courses at the university to prepare students for working with gifted children; it is common among adults that a gifted child does not need help; the absence of specific programs, technologies for working with gifted children; the deficit of psychological knowledge among adults about the individual and personality characteristics of the gifted children's behaviour and development (and they just have many personality problems in relations with adults and peers), etc.

All this again emphasizes the need for a unique strategy of pedagogical behaviour of adults and the necessity for humanistic technologies for working with children.

For the realization of the inherent potential of a child, joint creative activity with adults is especially important. At this time, the child seeks to 
imitate a significant adult, as a creative model, which is a prerequisite for the formation of his creativity. Getting into a new situation, he reproduces the ready method of action, repeats it after the adult in order to achieve the desired result. Subsequently, the imitation of the child becomes creative, he shows elements of novelty and self-activity, gets acquainted with various options for the implementation of innovative activities, determines his advantages in accordance with his own inclinations and skills without making significant changes. All this happens under the conditions of the "child-adult" commonness, a personality-oriented model of education, which is characterized by the following features:

- the adult in communication with children adheres to the provisions "not near, not over, but together":

- the adult's goal is to contribute to the formation of the child as a person. The adult's task: to ensure a sense of psychological security, the child's confidence in the world, the joy of existence, the formation of the foundations of the personality (the basis of personality culture), the development of the child's individuality;

- communication methods - understanding, recognition and acceptance of a child's personality, based on the ability to take a child's position which are formed in adults, taking into account his point of view and not ignoring his feelings and emotions;

- tactics of communication - cooperation;

- the adult's position - to take into consideration the interests of the child and the prospects of his further development as a full member of society;

- the view of a child as a full partner in the conditions of cooperation $^{21}$.

The participation in joint activities allows you to create those necessary conditions in which the child will not only receive knowledge from an adult, but also will develop his potential creative and cognitive abilities in conditions of interaction with him. It is the future unique picture of the world, created by the baby's own efforts, that forms the basis of his creative activity.

Creativity is stimulated by psychological safety, unconditional acceptance of the child's personality, his unconditional love. Unconditional

\footnotetext{
${ }^{21}$ Bila I.M. Psychology of children's creativity / I.M. Bila. - Kyiv., Phoenix, 2014. - 200 p.
} 
love, primarily of a loving mother, provides for the acceptance of a child regardless of his merits or demerits and is manifested in all sincere relationships. Unconditional love is an important condition that can ensure the full realization of the child's potential capabilities and talents. It is important for an adult not to interfere with a child's creation, to be near him in this process, to accept and understand his position, to be creative himself. It is important to turn to the child's natural ability to create, support, create favourable conditions for its manifestation and stimulate the children's desire to manifest originality.

A guideline in the selection by adults of adequate means of developing, educational and training impacts on a person is his age and individual life experience. It is worth dosing, repeating, varying creative tasks, taking into account the level of mental development, the abilities of each child, being in advance of children's plans, going a little ahead: what a child can do at the first stage with some help from an adult, later he can already do himself (according to L.S. Vygotskyi). This determines the change in emphasis from the analysis which is typical for most children of a certain age, to the search for the individual, special, unique one. It also broadens the adult's understanding of the possible manifestation of creative behaviour by a pre-schooler, and makes it possible to optimize his individual creative trends.

\section{CONCLUSIONS}

Childhood is a period of inexhaustible opportunities for development and growth of individual abilities and talents. It is important to cultivate in the child his essential powers, individual identity and uniqueness, to activate the mechanisms of self-development and creativity. Our structural model of studying, development of capabilities and awareness of adults, raising children, about the specifics and consistent patterns of their manifestation will help to accelerate the success of the growth of capabilities, the formation of a creative, harmonious personality in preschool age. In the course of the analysis of scientific researches, bibliographic data, we have found out the prerequisites of becoming a creative personality in the developmental space, the factors that stimulate the manifestation of capabilities at the initial stage of ontogeny within the proposed model of capabilities development. 


\section{SUMMARY}

A detailed analysis of the problem of capabilities allowed us to build a structural model of the development of children's capabilities, which takes into account the integrative, multidimensional structure of capabilities and the laws of their ontogenesis which are manifested in the individual characteristics of the course of mental processes (attention, perception, imagination, thinking, memory) and personality formations (orientation, emotional and value-based, volitional elements) in certain types of activities. This model lays the basis of the diagnostic tools developed by us, the methodology of studying the children's capabilities, the scale of rating the basic characteristics of capabilities.

A number of favourable prerequisites and factors of formation and flourishing of capabilities in childhood have been found out, the reasons that impede the realization of the children's creative potential have been analysed.

\section{REFERENCES}

1. Amstrong Thomas. Individual approach. How to grow and develop the mental abilities of your child independently. / Thomas Amstrong. Kharkov: Book club "Family Leisure Club", 2001. - 288 p.

2. Antoine de Saint-Exupery. The Little Prince / Antoine de SaintEncupery; translated from French - M.: Publishing house "Sofia", 2004. $144 \mathrm{p}$.

3. Bila I.M. Psychology of children's creativity / I.M. Bila. - Kyiv., Phoenix, 2014. - 200 p. $352 \mathrm{p}$.

4. Gary R. Promise at Dawn / Romain Gary. - M.: Azbuka, 2007. -

5. Ibuka M. After three it is already late / Masaru Ibuka. - M.: Olta, 2003. $-64 \mathrm{p}$.

6. Lobodina S.V. How to develop a child's capabilities / S.V. Lobodina. - St. Petersburg: Glagol dobro, Azbuka-Atikus, 2011. $320 \mathrm{p}$.

7. Losyeva A. A. Psychological diagnosis of giftedness: a textbook for high schools / A.A. Losyeva. - M.: Academic Project: Triksta, 2004. $176 \mathrm{p}$. - (The manual of a practical psychologist).

8. Nikolayeva E.I. Psychology of children's creativity E.I. Nikolayeva. St. Petersburg: Rech, 2006. -220 p. 
9. Gifted children: translation from English / edited by G.V. Burmenskaya and V.M. Slutskiy. - M.: Progress, 1991. - 376 p.

10. Platonov K.K. Problems of capabilities / K.K. Platonov. - M., Nauka, 1972. -312 p.

11. Rubinstein S.L. The problem of capabilities and questions of psychological theory // Psychology of individual differences / ed. by Yu.B. Gippenreiter, V.Ya. Romanova. - 3-rd ed., revised and accomplished. - M.: AST: Astrel, 2008. - P. 47-54. - (Reading book on psychology).

12. Russo J.-J. Selected writings / J.-J. Russo. - Moscow: Children's literature, 1976. - $187 \mathrm{p}$.

13. Savenkov A.I. The psychology of children's giftedness / A.I. Savenkov. - M.: Genesis, 2010. -440 p.

14. Subbotskiy S.V. The child opens the world / S.V. Subbotskiy M.: Prosveshcheniye, 1991. -207 p.

15. Twain M. Collected Works: in 12 volumes / M. Twain - M., 1961. - Volume 11. - P. 407-409.

16. Shadrikov V.D. Psychology of capabilities // Psychology of individual differences / ed. by Yu.B. Gippenreiter, V.Ya. Romanova. 3-rd ed., revised. and accomplished. - M.: AST: Astrel, 2008. P. 64-79. - (Reading book on Psychology).

17. Scheblanova E.I. Unsuccessful gifted schoolchildren / E.I. Shcheblanova. - M.: BINOM. Laboratory of Knowledge, 2011. -245 p.

\section{Information about the authors:}

Bila I. N.

Candidate of Psychological Sciences, Associate Professor at the Department of Psychology and Pedagogy of the V. I. Vernadsky Taurida National University 33, Ivana Kydri str., Kyiv, 01042, Ukraine 


\section{PSYCHOLOGICAL AND PEDAGOGICAL ACCOMPANIMENT OF A FOSTER FAMILY FOR FORMATION OF ORPHANED CHILDREN'S FAMILY VALUES}

\section{Dobrovolska N. A.}

\section{INTRODUCTION}

The dynamics of growth and the scale of development of orphanhood have become characteristic features of the social reality of the modern Ukrainian society, actualizing the need for studying various forms of social assistance for the living arrangements of the orphaned children. Of particular importance today are the studies of alternative forms of living arrangements for the children deprived of parental care. The family is an indispensable institution of socialization of a child, which allows her to master the basics of role-based behaviour in the assimilation of the social life standards. The priority of family upbringing is enshrined in international and Ukrainian legislation, however, more than 50,000 children deprived of parental protection are still being raised in specialized institutions for orphaned children ${ }^{1}$.

The reforming of the Ukrainian society to a large extent exacerbated the social problems of the population, which primarily affected its most vulnerable categories. New social groups and new social relations appeared, the socio-economic system changed, the value-semantic guidelines in the institutions of socialization changed. The alienation of parents from children, the growth of family deformation processes, the destruction of traditional moral and ethical principles, social ties, the deterioration of children's health, insufficient funding of the social sphere - all this led to a decrease in the level of protection of each person, and especially children. Such phenomena testify a deep destabilization of the society, the negative processes which are acquiring a national scale and pose a real threat to the national security. The decrease of the upbringing

\footnotetext{
${ }^{1}$ Комплексна допомога бездоглядним та безпритульним дітям: метод. посіб. / авт.: Безпалько О.В.; Гурковська Л.П.; Журавель Т.В. та ін. / за ред. Звєрєвої І.Д., Петрочко Ж.В. - К.: Видавничий дім «КАЛИТА», 2010. - 376 с.
} 
potential of a modern family, on the one hand, and the objective need to raise an orphaned child in the family conditions on the other hand, have become the prerequisites for creating an alternative institution for raising children who are, for various reasons, deprived of their family environment - the institution of a foster family. The process of its formation chronologically coincided with the period of transformation of the social protection system of the population, and therefore had a spontaneous character. The social need, which took shape, could not find a conceptual basis for effective realisation.

The phenomena of dysfunctions that arise during the functioning of the modern institution of the foster family are still being solved without sufficient scientific justification. On the theoretical level the structural features of the institution of the foster family and its functional potential have not been researched. Fundamental importance have the sociopedagogical characteristics of the positive and negative aspects of the institution of the foster family, the analysis of the basic prerequisites for its formation, achievements and miscalculations in its regulation, and on this basis, the development of adequate practical measures to increase the efficiency of its functioning.

To date, there has been a situation in which, on the one hand, we note the insufficient formation of the motivational complex for adopting a child into a family by adoptive parents, the lack of formation of family values in orphans, which requires the development of the content and methods of psychological and pedagogical accompaniment of this category of children.

\section{The concept of psychological and pedagogical accompaniment of the personality in the scientific literature}

The concept of "accompaniment" in the psychological and pedagogical scientific literature is often regarded as a synonym for support, assistance, compassion, cooperation, as a method and creation of specific conditions of mostly leading activity. Such understanding is found in the works of O.S. Gazman, S. Kurinna, A. Mashkarynets-Butko, G.M. Bevz, O.V Bespalko, L.P. Gurkovska, T.V. Zhuravel, V.V. Kuzmin, O.Ya. Shyshko, I.V. Manokhina.

Scientists consider psychological accompaniment as help to a child in making an independent choice of the life path. They emphasize that 
psychological accompaniment is a holistic process including the operational field of development, formation and correction of a personality, including several stages into this process: diagnostics, gathering information about problem solving methods, consultation at the decision-making stage, help at the implementation stage. So, O.S. Gazman introduced the concept of psychological and pedagogical accompaniment for children in solving individual problems associated with difficulties in physical and mental development and against their background, life selfdetermination, interpersonal communication and learning ${ }^{2}$.

The purpose of psychological and pedagogical accompaniment for children with special educational needs, according to A.G. Obukhivska, in the city's educational institutions is the study of personal potential and namely: the correlation of the level of mental development of the child and the age norm, the development of the cognitive sphere, the formation of motivation for learning; features of the emotional-volitional sphere; individual and characterological features, their creative and intellectual development through the involvement of all participants in the educational process (parents, teachers, children) in the implementation of the planned actions regarding the peculiarities of the development, communication, training; socialization and adaptation; vocational guidance for children with special needs ${ }^{3}$.

The concept of "pedagogical accompaniment" is presented in the works of E.G. Malynochka ${ }^{4}$, A.V. Kholod, V.L. Kholod and it envisages a process of interested observation, counseling, personal participation, encouraging the maximum independence of a child in a problem situation, the ability of a pedagogue to be near, follow a pupil, accompanying him or her on the individual educational route ${ }^{5}$.

Pedagogical accompaniment as a collaboration providing problemfree interaction, is considered in the concept of O.Ye. Kucherova. The researcher considers the dependence in the pedagogue-student interaction,

\footnotetext{
${ }^{2}$ Газман О.С. Педагогическая поддержка детей в образовании как ин-новационная проблема [Текст]/ О.С. Газман // Новые ценности образования: десять концепций и эссе. 1995. № 3. С. 58-63.

${ }^{3}$ Психологічний супровід інклюзивної освіти : [метод. рек] / автор. кол. за заг. ред. А.Г. Обухівська. Київ : УНМЦ практичної психології і соціальної роботи, 2017. - 92 с.

${ }^{4}$ Малиночка Э.Г. О педагогическом сопровождении формирования и развития личности [Текст]/ Э.Г. Малиночка. // Известия Академии педагогических и социальных наук. - 2008. - Ч. II. - C. 162-168.

${ }^{5}$ Холод В.Л., Холод А.В. Социально-педагогическая защита детей и молодежи в процессе психологопедагогического сопровождения в условиях единого воспитательного пространства сельского района [Текст] / В.Л. Холод, А.В. Холод // Известия Академии педагогических и социальных наук. - 2008. Ч. II. - C. 196-202.
} 
which consists in the fact that the pupil cannot solve the task independently and needs objective help, and the pedagogue cannot solve the student's task, since he will deprive him of his independence, and, therefore, the necessary development ${ }^{6}$.

We consider the psychological and pedagogical accompaniment as a condition for the successful development and psychological health of the orphaned children, which ensures the best assimilation of basic family values and practical knowledge, skills and abilities. We consider it a holistic process, the main components of which are the creation of conditions for the development of family life competencies and personal achievements, as well as monitoring the formation of relevant knowledge and skills.

Paying attention to the experience of various specialists in the formation of family values of orphaned children and children left without parental care in the conditions of a foster family we note the following: no document has a record of the mandatory preparation of orphaned children and children without parental care, to family life; the availability of programs to prepare nurselings for family life, the formation of views on the family depends on the activity and personal position of the administration and specialists in the field of accompaniment of this category of children.

In the process of the study, we have processed the programs which are actually operating at educational institutions and social organizations, aimed not only at preparing for family life, but also the formation of family values, beliefs about the family ${ }^{7}$. Their analysis showed:

1. The preparation for an independent family life and for the transition to a foster family is practically not carried out simultaneously in any institution for orphaned children and children left without parental care, and only one of the areas of preparation is being observed.

2. The transition of orphaned children and children left without parental care from one form of arrangement to another is carried out without taking into account the age and sex of the child, his or her

\footnotetext{
${ }^{6}$ Кучерова О.Е. Становление Человека и основные каноны педагогической поддержки личности [Текст] / О.Е. Кучерова // Известия Академии педагогических и социальных наук. - 2008. - Ч. II. C. 174-178.

7 Курінна С. Проблема соціального супроводу дітей дошкільного віку в дитячому будинку / С. Курінна // Актуальні проблеми психолого-педагогічного та соціального супроводу дитини на ранніх етапах со-ціалізації. Гуманізація навчально-виховного процесу: Спецвипуск 4, Част. 1. - Слов'янськ. 2010. - C. 198-203.
} 
ethnicity, etc., which does not fully reflect the process of forming family values in this category.

3. The educational programs do not sufficiently represent the system of work on the formation of family feelings between brothers and sisters living in the family conditions.

4. Not fully considered is the set of measures aimed at interaction in the system "parent-child", "child-child", etc.

In addition, the analysis of the experience of psychological and pedagogical accompaniment of orphaned children and children left without parental care in the conditions of a foster family allowed us to highlight a number of conditions necessary for the formation of family values in orphans and children left without parental care.

These may include:

1. Creating a favorable psychological climate for the family, where in orphaned children and children left without parental care the perception of the world, people and himself, moral feelings and emotions, moral knowledge about good and evil are formed; where the family team has a complex structure enshrined in customs, traditions, moral and legal norms, within which children, parents, grandparents are united by a whole system of relations - between elder and younger children, between children and parents. These very relationships determine the value of the family for orphans and children left without parental care, leave a unique imprint on the child - after all, it is in the family that a child acquires knowledge, abilities and skills in various fields and, above all, in the field of communication, human relations, and also gets the experience of living together.

2. Creating a success situation for orphaned children and children left without parental care makes it possible to achieve significant results both for a single individual (in this case, an orphan child), and for the team as a whole, namely for the family. The success situation is especially important in dealing with orphaned children and children left without parental care, whose behavior is complicated by a variety of external and internal causes, as it allows them to eliminate aggression, overcome isolation and passivity. Orphaned children in a situation of success receive a feeling of satisfaction from the fact that the results of their activities exceeded their expectations. In turn, the adoptive father leads his nurseling progressively upward, climbing with him the ladder of 
knowledge, psychological self-determination, gaining faith in himself and people around him. An important role in this process have pedagogical situations specially prepared by parents in the conditions of a foster family in which the child gets an opportunity to reveal unexpectedly his own abilities for himself. Father may not prepare such situations on purpose, but his educational potential will be manifested in the fact that he will not miss this moment, he will evaluate it correctly and will be able to materialize it. The main condition for creating a success situation is communication as a process of interconnection and interaction of subjects (groups, individuals), in which takes place an exchange of activities, information, experience, capabilities, abilities and skills, as well as the results of activities; one of the necessary and general conditions for the formation and development of the society and individual. The real intermediaries of all forms of communication in the "foster family orphaned children" system are not only the results of spiritual activity ideas, values, ideals, feelings and moods, but also material things - tools and means of human labour, objects that embody social values and human experience. The above mentioned allows to say that in the process of communication value-social experience is transferred and assimilated, there is a change in the essence of interacting entities (orphaned children and children left without the care of parents and foster parents), value relationships are formed and socialization of a personality takes place.

3. Increasing motivation for adopting children to a foster family. In the formation of family values in orphaned children and children left without parental care, the stage of preparing foster parents plays a significant role. Great importance is attached to developing among foster parents a real awareness of the motives and expectations from adopting a child, an adequate assessment of their own resources that will be required for successful socialization and upbringing, as well as identification of possible risks and threats. Based on the analysis of programs and research, the following factors of the efficiency or inefficiency of foster families can be distinguished:

- the ability of the family to become involved in the new social roles that arise in the process of joining the family system by new members;

- personal characteristics of foster parents, in particular, the flexibility of role-playing behavior; 
- the possibility or absence of a satisfactory information exchange on the upbringing of orphaned children and children left without parental care;

- the length of institutional stay (the length of stay in an orphanage);

- non-inclusion of a foster family into the system of psychological and pedagogical assistance and accompaniment, etc.

Thus, the study of the experience of the state educational and social institutions with foster families allowed us to identify the most effective conditions, as well as the leading areas of activity of various specialists and ways of forming family values in orphaned children and children left without parental care.

A necessary condition is the creation of a multifunctional accompaniment service, built on the principle of individual and joint activity of all subjects of the educational process - pedagogues, educators, parents based on subject-subject relations. However, it should be noted that in educational and social institutions attention is paid only to subjects of the educational process, namely, to the pupils and teachers, while foster parents remain involved in the process of accompaniment of orphaned children and children left without parental care. The above mentioned actualizes the activities of educational and social institutions, which should act as the center of interaction of the system "foster family - specialists of social institutions - pedagogues of educational institutions".

\section{Comprehensive program of psychological} and pedagogical accompaniment of a foster family for the formation of orphaned children's family values

The theoretical study of the problem allowed us to develop a comprehensive program of psychological and pedagogical accompaniment for the foster family, that is, for foster parents and orphans. This comprehensive program was implemented in Mykolayiv regional orphanage (the city of Mykolayiv). The comprehensive program of psychological and pedagogical accompaniment of the foster family includes the following blocks: target, content-related, organizational and monitoring. The purpose of the comprehensive program of psychological and pedagogical accompaniment is the formation of family values in orphans and children left without parental care in the conditions of a foster family. Due to the fact that the formation process is carried out in a foster family with the participation of various subjects (professionals who carry 
out the accompaniment, parents, children themselves), the target block also includes target guidelines for foster parents in the conditions of the orphanage, which is the main basis for the experimental study. These guidelines consisted in the pedagogical accompaniment of parents on the basis of the purposeful formation of their common pedagogical culture and competence which ensures the creation of the emotional well-being of the orphaned child in the family and subsequent adaptation, the formation of a value attitude to the world, to the family, to other people, to himself and self-realization in society. The content-organizational block reflects the specifics of the content of psychological and pedagogical accompaniment of foster parents in accordance with the main functions of the pedagogue, pedagogical tools for its implementation at different stages of the formation of the foster family for the formation of family values in orphaned children and children left without parental care. The main components of the comprehensive program of psychological and pedagogical accompaniment of the foster family, orphaned children and children left without parental care for the formation of family values are presented in Figure 1.

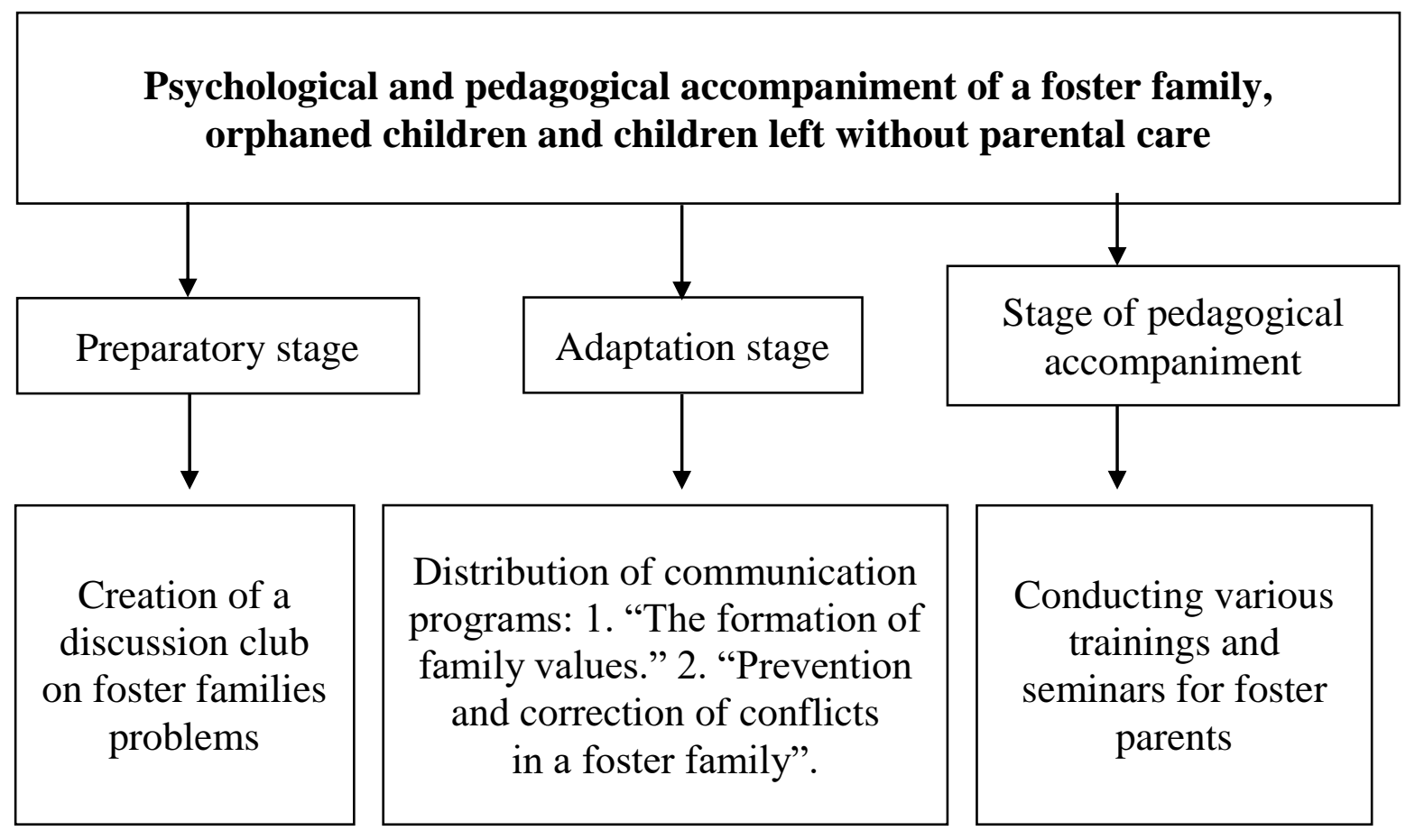

Fig. 1. Comprehensive program of psychological and pedagogical accompaniment for foster families, orphaned children and children left without parental care 
The implementation of the comprehensive program includes several stages: preparatory, adaptation and supportive. Let us consider these steps.

1 . The preparatory stage of psychological and pedagogical accompaniment of a foster family included the development and testing of the theoretical module of the training program with foster parents, as well as with experienced foster parents in the framework of the discussion club on foster families problems, which was invariant (unchanged), focused on any contingent of parents. The result of work at this stage is the increase of the level of foster parents' socio-psychological and pedagogical competence; mastering the ways of positive communication and interaction with the child; receiving psychological and emotional support.

2 . At the adaptation stage, a practical module was developed and put into practice, including the programs "Formation of family values", "Prevention and correction of conflicts in a foster family", which were of a variable nature and were adapted to the needs and problems of foster families. The result of this stage is the optimization of parent-child relationships, increasing the level of pedagogical competence of foster parents, increasing the level of formation of family values in orphaned children and their readiness for self-realization in society.

3 . The stage of pedagogical support to psychological and pedagogical accompaniment of foster families is aimed at implementation of a set of activities (trainings, seminars, courses, etc.) that complement the content of the above mentioned programs, taking into account the needs of the foster family and orphaned child in obtaining additional knowledge about the family, family values, own "Self". The result of this stage is the exchange of experience between foster parents, the interaction of all entities involved in working with foster families, orphaned children and children left without parental care, further development of family values in orphaned children and children left without parental care. All these stages do not have clear boundaries and are complementary.

The monitoring block provided the check of the effectiveness of the implementation of the comprehensive program of psychological and pedagogical accompaniment for foster parents and presented a system of step-by-step pedagogical diagnostics of the motivation for adopting an orphaned child into the family and the level of formation of family values in orphaned children and children left without parental care in a foster family. The logic of the stages, the implementation of the comprehensive 
program of psychological and pedagogical accompaniment of the foster family for orphaned cgildren and children left without care, depended on the results of the ascertaining stage of the research work and the peculiarities of the problem field of foster families.

Let us characterize in more detail the content-related and organizational block of the comprehensive program of psychological and pedagogical accompaniment of foster parents. At the first stage preparatory - a discussion club was created to discuss the problems of adoptive parents. The purpose of work of foster parents' discussion club is the psychological and pedagogical education of foster parents, help in preserving and strengthening of the psychological health of orphaned children and parents, promotion in creation of a wider network of contacts of foster parents with children, the increase of knowledge of foster parents on organizing family activities, forming family values in orphaned children and children left without parental care. The main objectives of the activities of the foster parents discussion club are: expanding and deepening the knowledge of parents in the field of preschool and school psychology and pedagogy; determination of the circle of common problems that arise in families raising orphaned children and children left without parental care; teaching foster parents of ways of positive communication and interaction with orphaned children; self-esteem of parental positions, overcoming stereotypes of parental behavior; providing emotional support to foster families, club members. In the course of the club's activities, trainings were held for parents for the topics: "Learning to understand each other", "Feelings of parents and children. Rules for the manifestation of feelings", "Family and family interaction." After conducting training sessions, the participants exchanged impressions about their work in the group, analysed the results of joint activities, that is, reflection was carried out. The coaches of the training sessions note the desire of the foster parents to attend classes aimed at studying the motives of the "good" and "bad" behaviour of the children, identifying their resource opportunities for raising orphaned children and the formation of family values in them. It is important to note that the implementation of the program envisaged holding classes aimed at all club members, as well as classes which are determined by the needs and problems of foster families. Their content was targeted, taking into account the particularities of socialization of orphaned children and children left without parental care, 
the level of professional competence of foster parents in the formation of family values. The variability and consideration of the problem field of an individual family made it possible to make the process of accompaniment of foster parents personality-oriented and targeted.

\section{Analysis of the results of implementation of a comprehensive program on living arrangements for orphaned children and children left without parental care in Mykolayiv regional orphanage}

The experimental data were collected through questionnaires, testing, observation, and then studied and worked out, which allowed us to give a qualitative analysis of the results received. The research and experimental work included three stages: ascertaining, forming, control and analytical. The purpose of the ascertaining stage is to identify the problematic field of formation of family values in orphaned children and children left without parental care in conditions of a foster family. Let us note that the specificity of the purpose and content of the experimental work required from us to conduct simultaneous diagnosis of parents - candidates for foster parents and orphaned children which determined the solution of the following tasks at the first stage of the experimental work: 1) to determine the motivational complex for the adoption of orphaned children and children left without parental care by foster parents; 2) to identify the initial level of formation of family values in orphaned children and children left without parental care. At first, we carried out a diagnosis of foster families, which allowed us to obtain general information about the composition and level of preparedness of future parents, and to identify the motivation for choosing a foster child. To obtain general information, we used a method - analysis of documents. To do this, we analysed statistical data on parents of foster families and candidates for foster parents.

Direct work was also done to advise foster parents. So, a foster father raising 4 orphans and children left without parental care, came to the orphanage with a problem associated with the aggravation of relations with the child (11 years old), who had been raised in the family for 1 year 4 months. The conflict situation is due, according to the foster father, the presence of certain hostility on the part of two children previously adopted into the family (3 years). In order to solve the situation, not only the specialists of the orphanage were involved in the work with the family, but also the participants of the parents' discussion club. In another case, it was 
necessary to combine the efforts of the family, accompaniment specialists and pedagogues of the orphanage. After accepting Stepan V. (10 years old) for foster care, the child lost the desire to study, despite the fact that he had this desire before the death of his biological parents, the foster parents failed to establish the reason for the child's unwillingness. In the process of work of psychologists and pedagogues it was found out that children who studied together in a comprehensive school teased him, calling him "a bastard." Having done appropriate work with classmates, teachers, parents and psychological and pedagogical rehabilitation with Stepan V., the indicators of motivation to study increased. Joint work with parents helped to establish the relationship of the teenager with foster parents, it demonstrated to Stepan V. the sincere desire of the parents to help him in solving his problems. The examples given show the need for a variant component conditioned by the individual factors of the child's stay in the family, his or her psychological characteristics. The result of the lessons was the establishment of emotional contact of the child with the father, the awareness of the peculiarities of communication with family members, understanding the need for creating conditions for trustful communication with children.

At the adaptation stage there were implemented the programs "My Family Values" and "Prevention and Correction of Child-Parent Conflicts". The specific character of the program "My Family Values" is in implementation of a systematic approach to the formation of family values. The program included the following content blocks:

1. "I am a family man" (work with a child): preservation of a positive attitude to his past and his family and formation of a sensible position "I am a family man";

2. "I am a father" (the development of a motivational complex for the adoption of a child, the level of pedagogical culture and the formation of parental competence in the formation of family values in orphaned children).

The purpose of the program: formation of family values in orphaned children. The main tasks of the program "My Family Values" are:

1. Creating a psychological and pedagogical space that fosters a positive attitude towards the family.

2. Creation of a family orientation, favorable conditions that contribute to the actualization of family values. 
3. Teaching the basics of social interaction as a condition of full-scale self-realization in society and family.

Within the framework of the program implementation, the following forms of psychological and pedagogical accompaniment were used: thematic seminars, workshops and trainings, educational games, discussions, as well as consultations held outside the organized collective classes at the parents' request. A psychologist, a social pedagogue and a family psychologist participated in the program. In the course of the implementation of the block of work with the child ("I am a family man" block) various methods, techniques and forms of conducting lessons were used: conversations - in order to establish problems of the child, to explain to him or her family traditions, rules of life in the family, etc.; a training lesson "My roots", which is aimed at helping to realize the influence of the past on life, rejecting stereotypes of negative behaviour; a course of behavioural therapy aimed at correcting the behaviour of orphaned children, teaching to control emotions; thematic lights - "You and Your Parents", "Mom' is the First Word", games "Home", "Family - I" aimed at actualizing the role of mother and father in shaping the family values of orphaned children, the role of the family in a person's life; competition program "Brother, sister and I are a close-knit family", focused on restoring lost family ties; the course "Preparing children for family life", which considers the culture of a family behaviour, the alphabet of family communication, family nutrition, means of communication with relatives, family health, life safety in the family, useful economy, family holidays, housekeeping, etc. A positive moment of realization of this block is the filling in the "Book of Life". This book is a story of the child himself, a chronicle of what really happened and why. Each child chooses his own form of book. For the child to be able to trace his or her growth visibly in the conditions of foster care, he or she is invited to start in the Book of Life a page of achievements individual map called "Path to the top named "I". The map is a pyramid consisting of numerous conventional bricks on which the child writes down his or her new achievements. The children, characterizing the positive experience of keeping the "Book of Life", noted: "..." The book of life" helps me to know myself...", "keeping the book helped me to revise my view of the world", "I began to understand the value of the family I found", "Now you can see my life as a dark stage that has remained in the past, and a light one, which is now and ahead...". 
The work with foster parents ("I am a father" block) included: group classes with training elements "What is my family?", "Learn your parental Self", "Family upbringing styles", "Conflict resolution", aimed at defining the concept and family functions, attitude to the upbringing process, drilling of cooperation skills and equal relations with the child; meetings with representatives of guardianship authorities, - police, a narcologist, a family psychologist, in order to resolve the issues of restoring a child's biological family, organizing work with children of the "Risk group", restoring parent-child relationships. The actions arranged were aimed at the development of familial, friendly relations between foster parents and orphaned children, as well as with other family members. In the course of the study, we observed the following: a manifestation of the desire to live together in a family, help each other, listen and respect the elders, take care of the younger ones, as well as a positive attitude towards adoptive parents, grandparents, a desire to live in a secured family, with family holidays and traditions. As part of the program activities, various types of exercises were used to form the components of family values. So, in order to form the understanding of gender family roles and respect for them, we used the exercise "Compliments", which develops communication skills, goodwill, and positive attitudes towards each other. Our observations allow us to note the respectful attitude of boys to girls, the manifestation of courtship, masculinity and femininity, empathy.

The program "Prevention and correction of parent-child conflicts" was also implemented in the conditions of the Orphanage. The main goal of the program is to provide psychological and pedagogical accompaniment for foster families, create conditions for the successful adaptation of orphaned children and children left without parental care in a foster family, and the prevention of parent-child conflicts and the formation of family values in orphaned children. As part of the program, specialists, together with representatives of departments of the system for the prevention of parentchild conflicts in orphaned children, provided assistance to a foster family to solve these problems. During the period of the experimental study, at the adaptation and supportive stages of our research work, a set of activities was carried out - trainings, seminars, courses aimed at studying the features of upbringing of orphaned children, the formation of socially significant and family values, the exchange of experience between adoptive parents and the interaction of all entities involved in work with foster families. 
Our role in the implementation of the content-related and organizational block of the program of psychological and pedagogical accompaniment was to mentor and individually accompany the foster family, in order to prevent abandonment of the orphaned children as a result of a conflict situation, misunderstanding of the age characteristics of children and lack of knowledge on their upbringing. According to our observations, the children felt satisfaction from their new position, fulfilled the instructions of their parents desirably, felt joy and anxiety at the same time, anxiety due to the fear of losing their parents. At the same time, we observed that other children previously accepted into the family felt jealous of their parents and rejection of new children in the family. For our part, we have determined an individual plan for foster family accompaniment, including training sessions, individual and group consultations aimed at relieving tension and uniting the family. According to the results of the work, there was a positive dynamics in family relations. The newcomers began to communicate more closely with other children, family members and others. The elder children in the family with a great desire began to help with housekeeping, to carry out joint jobbing, to take more responsible attitude to homework. Foster parents are satisfied with their role and the situation in the house; they are pleased that the children have taken root well in the family.

The control and evaluation of our work was carried out by almost everyone who took part in this process. The main thing for us was the assessment of the children themselves, who gained experience in family education. Let us quote the children: "the family is a reliable pier which saves from any adversity, helps in a difficult situation", "in the family you are loved just because you exist, not demanding anything in return", "for me the family is something beautiful and unattainable, what I never had and what I want to create. I want to see how people cling to each other, I want to be a link in this strong chain, I want to trust and rely." It is necessary to note the changes in the views of adoptive parents on the process of raising orphaned children and children left without parental care, and the formation of family values. Here are some reviews and opinions of parents: "The club is very necessary in the upbringing of both foster and natural children. Firstly, this is an acquaintance of foster families. Previously, we knew practically nothing about each other. And now we have not only learnt, begun to communicate and started 
celebrating some holidays together, making calls, consulting and sharing experience. The club taught us to understand our children better, to look at life through their eyes, to deal with the most difficult situations. During the classes you can get an individual consultation. And just become more selfconfident, recharge yourself with lots of positive energy"; "The school of foster parents allows you to feel that you are not alone with your problems. You feel relaxed and self-confident. The pedagogues are excellent specialists in their field; I thank them very much for everything. When problems pile up and you don't know what to do, it seems that the world is collapsing and there is no one to help. Now you can already afford it. And there were so many problems before. It's a pity that the school didn't arise earlier. Now I know what to do in one case or another. And, most importantly, who to contact. A few points that came in handy for me and will be needed in the future: the language of acceptance and rejection (intonation of voice, posture) plays a very large role, which I did not know and did not even imagine that it was so important. Thank you so much for everything and everyone. School is very important and necessary"; "I used to think that I knew all or almost everything about upbringing children. But after our lessons, I realized that I was deeply mistaken. You helped to look at orphaned children upbringing and family values formation in a different way. Now, before making any decision, I will think it over once more, I will remember our lessons"; "I learned not only to listen, but also to hear children. Many tips help to understand children's behavior and accept them for who they are. The school is especially needed when you are just starting out. The specialists of the school teach how to react and evaluate children correctly. I'm not a psychologist, I'm just a mom, without special education, at the classes I learned how to find a way out of conflicts, I learned to see the child from the inside. I was once again convinced that raising a child is difficult, and our children with wounded souls are special. And now I know that, having asked for help, I will receive it without fear of being ridiculed. I thank you very much as mother!"

In general, as we see from the above examples, the implementation of the comprehensive program has yielded positive results. For experimental verification of the effectiveness of the comprehensive program of psychological and pedagogical accompaniment of the foster family, orphaned children and children left without parental care, we organized a control phase of diagnosis. According to the "Me and My Family" 
questionnaire, we note an increase in the number of orphaned children and children left without parental care, with high and middle level and a decrease - with a low level. The dynamics of the formation of family values according to the questionnaire "Me and My family" are shown in Figure 2.

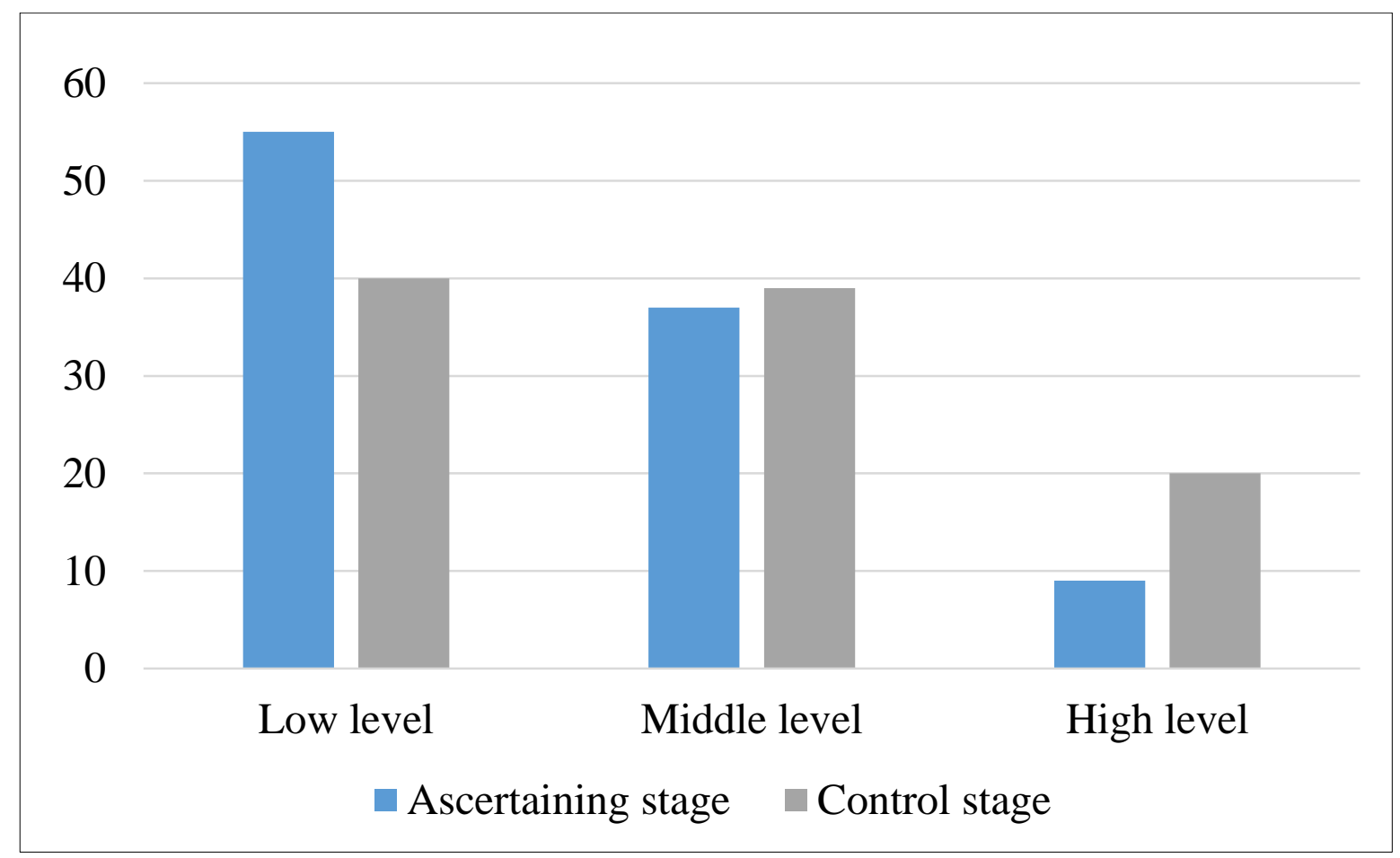

Fig. 2. Dynamics of family values formation in orphaned children

The share of the children with a high level of formation of family values increased from 9 to $20 \%$. In this group of children there is respect for elders, care for younger ones, willingness to help all the members of the family (need-motivational, emotional, activity-practical criteria). But at the same time, neuropsychiatric disorders are noted in the orphaned children and the children left without parental care which impede the formation of family values to the full extent (emotional aspect).

The middle level is a characteristic of $39 \%$ of orphaned children. In this group mutual understanding and mutual assistance in the family are manifested, family values are accepted, but there are motives that attract children more with rest and leisure rather than with understanding the importance of family recreation, family leisure and family traditions (needmotivational criterion). 
The number of respondents with a low level decreased from $55 \%$ to $40 \%$. They noted the presence of discomfort (emotional aspect), the occasional participation in family affairs, and the presence of difficulties in establishing contacts between family members (activity-practical criterion). However, it should be noted that in the conclusion of our experiment no home escapes were committed, which testifies to the child's desire to live in family.

Thus, the obtained results show that most orphaned children and children left without parental care positively changed their views on the family, on the organization of family life; there can be marked expressed family values, such as respect for elders, participation in family affairs, friendly relations with all family members, etc., which, in our opinion, testifies to the effectiveness of the measures taken as part of a comprehensive program of psychological and pedagogical accompaniment for orphaned children and children left without parental care. So, the conducted study allowed us to increase the level of formation of family values in orphaned children and children left without parental care, in the conditions of a foster family, which allows us to talk about its effectiveness.

\section{CONCLUSIONS}

The analysis of the domestic practice of psychological and pedagogical accompaniment of foster families proved the objective contradictions between the recognition of the need for a purposeful process of forming family values in orphaned children in the conditions of a foster family and the unsystematic nature, fragmentarity of such activities in the real practice of family upbringing and psychological and pedagogical accompaniment of family living arrangements for orphaned children.

The practice of upbringing confirms the need to pay closer attention to preparing foster parents for organizing the process of family upbringing and the process of forming family values in orphaned children, and organizing psychological and pedagogical accompaniment for such process.

The content and methods of psychological and pedagogical accompaniment of the orphaned children in the conditions of a foster family should be designed in accordance with the nature of the problem field of the foster family: the existing experience of the family upbringing 
of foster parents, the motivation for adopting an orphaned children into the family, the experience of living of an orphaned child in the family and the level of formation family values.

In accordance with the goals of family upbringing and family living arrangements for the orphaned children, the following criteria and indicators of the formation of family values in orphaned children and children left without parental care in the conditions of a foster family were identified: need-motivational (significant needs, manifestation of kinship feelings, value orientation to family life) cognitive (knowledge about the family and its role in human life; understanding of the relationship between family members); activity and practical (inclusion in the household life of the family, mastering housekeeping skills), emotional (mutual sympathy between family members, emotional state).

According to the results of the experimental work, a positive dynamics was revealed in the relations between the orphaned children and adoptive parents, which indicates the validity and effectiveness of the developed comprehensive program of psychological and pedagogical accompaniment for orphaned children and children left without parental care in the conditions of a foster family.

\section{SUMMARY}

This article deals with the psychological and pedagogical accompaniment of a foster family as a condition for the successful development and psychological health of orphaned children, which provides the best assimilation of basic family values and practical knowledge, skills and abilities. We consider it a holistic process, the main components of which are the creation of conditions for the development of family life competencies and personal achievements, as well as monitoring the formation of relevant knowledge and skills.

The comprehensive program of psychological and pedagogical accompaniment of the foster family includes the following blocks: target, content-related, organizational and monitoring. The goal of the comprehensive program of psychological and pedagogical accompaniment is the formation of family values in orphaned children and children left without parental care in the conditions of a foster family.

The result of the program is a positive change in views on the family, on the organization of family life, the formation of family values in 
orphaned children: respect for elders, participation in family affairs, friendly relations with all family members, etc., which in our opinion, testifies to the effectiveness of the measures taken.

\section{REFERENCES}

1. Аналітичний звіт «Життєвий шлях випускників інтернатних закладів, дитячих будинків сімейного типу та прийомних сімей» / О.М. Балакірєва, I. М. Чернін, О.М. Хмелевська та ін. К.: Український Інститут соціальних досліджень ім. О. Яременка, - 2010. - 106 с.

2. Бевз Г.М. Прийомна сім'я: соціально-психологічні виміри: Монографія / Г.М. Бевз. - К.: Видав. Дім «Слово», 2010. - 352 с.

3. Газман О.С. Педагогическая поддержка детей в образовании как ин-новационная проблема [Текст] / О.С. Газман // Новые ценности образования: десять концепций и эссе. 1995. № 3. С. 58-63.

4. Захист дітей, які потребують особливої уваги суспільства. Статистичний збірник. Київ - 2018. - Режим доступу: http:// www.ukrstat.gov.ua/druk/publicat/kat_u/2018/zb/07/zb_zdpus_2017.pdf

5. Комплексна допомога бездоглядним та безпритульним дітям: метод. посіб. / авт.: Безпалько О.В., Гурковська Л.П., Журавель Т.В. та ін. / за ред. Звєрєвої І.Д., Петрочко Ж.В. - К.: Видавничий дім «КАЛИТА», 2010. - 376 с.

6. Кузьмін В.В. Теоретичний аналіз проблеми інтеграції у суспільство дітей-сиріт та дітей, позбавлених батьківського піклування: соціально-психологічний аспект / В.В. Кузьмін // [Електронний ресурс]. - Режим доступу: http://journals.uran.ua/apppfo.

7. Курінна С. Проблема соціального супроводу дітей дошкільного віку в дитячому будинку / С. Курінна // Актуальні проблеми психолого-педагогічного та соціального супроводу дитини на ранніх етапах со-ціалізації. Гуманізація навчально-виховного процесу: Спецвипуск 4, Част. 1. - Слов'янськ. - 2010. - С. 198-203.

8. Кучерова О.Е. Становление Человека и основные каноны педагогической поддержки личности [Текст] / О.Е. Кучерова // Известия Академии педагогических и социальных наук. - 2008. Ч. II. - C. 174-178.

9. Малиночка Э.Г. О педагогическом сопровождении формирования и развития личности [Текст] / Э.Г. Малиночка. // Известия 
Академии педагогических и социальных наук. - 2008. - Ч. II. C. $162-168$.

10. Манохіна I.В. Соціально-педагогічна робота 3 дітьми-сиротами та дітьми, позбавленими батьківського піклування: навчальний посібник / I.B. Манохіна. - Дніпропетровськ: Дніпропетровський університет імені Альфреда Нобеля, 2012. - 276 с.

11. Машкаринець-Бутко А. Особливості роботи соціальних працівників у дитячих будинках сімейного типу / А. МашкаринецьБутко // Науковий вісник Ужгородського національного університету: серія «Педагогіка. Соціальна робота». - 2008. - № 14. - С. 98-101.

12. Психологічний супровід інклюзивної освіти : [метод. рек] / автор. кол. за заг. ред. А. Г. Обухівська. - Київ : УНМЦ практичної психології і соціальної роботи, 2017. - 92 с.

13. Холод В.Л., Холод А.В. Социально-педагогическая защита детей и молодежи в процессе психолого-педагогического сопровождения в условиях единого воспитательного пространства сельского района [Текст] / В.Л. Холод, А.В. Холод // Известия Академии педагогических и социальных наук. - 2008. - Ч. II. С. 196-202.

14. Шишко О.Я. Прийомна сім'я як спосіб вирішення проблеми соціального сирітства / О. Я. Шишко // Психологія особистості. 2010. - № 1. - C. 210-218.

\section{Information about the author:} Dobrovolska N. A. $\operatorname{Dr}(\mathrm{PhD})$,

Head of the Department of Physical Education, Sports and Human Health of the V. I. Vernadsky Taurida National University 33, Ivana Kydri str., Kyiv, 01042, Ukraine 


\section{THE INFLUENCE OF SEDATIVE INDUCTOTHERAPY ON APPETITE}

\section{Fedorych O. V.}

\section{INTRODUCTION}

The state of psychological comfort and the feeling of a person's quality of life depend to a large extent on how organically this person perceives his own image in the society. Very often, the perception of one's own image in a person arises under the pressure of an external assessment. This imposed image makes a person strive for some average standards, both in their own appearance and in social behaviour.

Very often, people experience psychological discomfort from their appearance: it seems to them that their body mass is excessive. Especially this discomfort becomes significant when a person learns from doctors about the beginning of alimentary obesity development.

If people find a simple, safe and enjoyable way to reduce their appetite, and this leads to the normalization of their weight, then, as a result, this will increase their self-esteem, which will significantly improve the quality of life of these people. Without mentioning the health benefits and longevity of this person.

The search for such a way to reduce appetite occupies the minds of a large number of researchers. And we, analysing the experience gained at different times at the junction of different fields of knowledge, tried to make our practical and theoretical contribution to solving this global problem. In modern Ukraine, this question is exclusively studied by nutritionists (V.I. Tsypriyan, S. Fus) and pharmacologists (I.S. Chekman, A.P. Viktorov). Unfortunately, there are no studies for this topic in the field of physiology and biophysics in open scientific publications.

\section{The purpose of the article.}

The purpose of our study is to investigate the possibility of the influence of our author's method of sedative induction therapy on a decrease in appetite. The method of inductotherapy has a rich history and attention to it, in our opinion, is undeservedly low. Nevertheless, at the present time, when the scientific community has again touched upon the 
topic of circadian rhythms, interest in the method of induction therapy again, we believe, should revive.

We set ourselves the goal of finding out on a group of volunteers the possibility of reducing their appetite by external electromagnetic influence in the range of long radio waves, which, in our opinion, takes place in nature constantly at night, at a time when the activity of the human body is minimal due to the sedative circadian rhythm which is dominant at this time.

\section{The effect of circadian rhythms on the duration of sleep and the quality of human life}

From the very beginning, life on Earth had to adapt to the fact that day is regularly replaced by night, and night is replaced by day. Almost all living things have acquired a special clock mechanism that switches the body from day mode to night mode and vice versa. The most vivid demonstration of how the biological clock works is the alternation of sleep and wakefulness. But the biological clock is not only sleep. It is known that during the day and at night we have different body temperatures, that during day and at night our hearts and blood vessels work differently, that metabolism is subject to daily (or circadian) fluctuations. And the same can be said about other living organisms - about animals and plants, about unicellular and multicellular living beings ${ }^{1}$.

Of course, it is worth recalling how much knowledge of the circadian mechanism means for biology, medicine and psychology. Recently, we increasingly hear about the problems which can arise due to broken biological clocks - which is not surprising when you take into account how many things depend on them.

And it's not just about sleep disturbances; There is evidence that due to problems with circadian rhythms, the likelihood of oncological diseases increases, and that an upset biological clock contributes to the accumulation of excess fat - with all the resulting metabolic problems ${ }^{2}$.

The 2017 Nobel Prize in Physiology or Medicine was awarded for the discovery of genes that determine the functioning of a biological clock, an intracellular mechanism that controls cyclic fluctuations in the intensity of various biological processes associated with a change of day and night.

\footnotetext{
${ }_{1}^{1}$ Алякринский Б.С., Степанова С.И. По закону ритма. - М.: Наука, 1985. - 175 с.

2 Агаджанян Н.Л., Губин Г.Д., и др. Хроноархитектоника биоритмов и среда обитания. М. - Тюмень: изд-во Тюменского гос. ун-та, 1998. 168 с.
} 
Daily or near-daily (circadian) rhythms are present in all living organisms from cyanobacteria to higher animals ${ }^{3}$.

It is necessary to understand that any achievement that is awarded such an honorary title is based on the research of its predecessors. The first idea of a biological clock appeared back in the 17th century, when the French astronomer Jean-Jacques de Mairan discovered that the diurnal rhythm of leaf movement in plants occurs even in the dark, it is "programmed" in the plant itself and is not caused by the environment. From this moment, work for the study of the phenomenon began. It was found out that almost all living organisms are able to form cyclic processes with a daily or circadian period. It turned out that in the absence of the main external factor of synchronization - the change of day and night organisms continue to live in a diurnal rhythm, although the period of this rhythm, depending on individual characteristics, becomes slightly shorter or longer than twenty-four hours ${ }^{4}$.

The basic mechanisms of circadian rhythms are known now, but many details remain incomprehensible. For example, how several "hours" coexist in one organism at the same time, how several processes are realized referring to different periods? When experiments were conducted during which people lived in rooms or in a cave without external information about the time of day or night, amazing results were obtained. In the experiment participants, body temperature, secretion of steroid hormones, etc., had a period of about 25 hours. At the same time, the periods of sleep and wakefulness, although on average also stayed around the daily one, for some participants ranged from 15 to 60 hours 5 .

The study of circadian rhythms is also important for understanding the functioning of the organism in extreme conditions, for example, in the Arctic, when during the polar day and night the natural factors of synchronization of circadian rhythms disappear. There is convincing data that with a long stay in such an environment, a person experiences significant changes in the circadian rhythms of a number of body functions ${ }^{6}$. Now it is becoming clear that this is one of the factors that affects human health, and when the molecular basis of circadian rhythms is

\footnotetext{
${ }^{3}$ Тимченко А.Н. Основы биоритмологии: учебно-методическое пособие / А.Н. Тимченко. - Х. : ХНУ имени В.Н. Каразина, 2012. - 148 с.

${ }^{4}$ Доскин В.А., Лаврентьева Н.А. Ритмы жизни. - М.: Медицина, 1991. - 176 с.

${ }^{5}$ Wever R. The circadian multi-oscillator system of man // Int J Chronobiol. 1975. V. 3. N. 1. P. $19-55$.

${ }^{6}$ Мошкин М. П. Влияние естественного светового режима на биоритмы полярников // Физиология человека. 1984. Т. 10. № 1. С. 126-129.
} 
known, it is possible to analyse which gene variants are more or less favourable for working in polar conditions ${ }^{7}$.

Circadian rhythms affect metabolic processes, the functioning of the immune system and inflammation, blood pressure, body temperature, brain function and much more. The effectiveness of certain drugs and their side effects depend on the time of day. In case of a forced mismatch between the internal clock and the external one, for example, as a result of a latitudinal flight or working on a night shift, various dysfunctions of the body can be observed: disorders of the gastrointestinal tract and the cardiovascular system, depression, and the risk of developing oncological diseases increases ${ }^{8}$.

The periods of sleep and wakefulness in humans are replaced with circadian periodicity. In studying the relationship between the frequency of sleep and wakefulness with external stimuli, the change in the duration of the period of these fluctuations in humans were researched. In the absence of such stimuli as light, which allows a person to judge the time of day, the people who participated in the experiment went to bed anyway and woke up at the usual time. Thus, the period of the sleep-wake rhythm did not change and for some time remained equal to 24 hours, however, after a while it increased to 36 hours. When the volunteers returned to normal conditions, the 24 hour cycle was restored. Thus, humans and many other animals have internal clocks that go even in the absence of external signals. One of the most common external signals is light. In humans, receptors located in the retina respond to light and send a signal to the suprachiasmal nucleus. Further signal propagation leads to the production of hormones that regulate the circadian activity of the body. However, at the same time, such organs as the heart, liver, and kidneys have their own "internal clocks" and they can be knocked out of the rhythm established by the suprachiasmatic nucleus. The signal entering the pineal gland causes the synthesis and release into the bloodstream of the sleep-causing neurohormone melatonin (N-acetyl-5-methoxytryptamine). Older people produce less melatonin, which probably explains why older people are more likely to suffer from insomnia. Most researchers believe that the suprachiasmatic nucleus is responsible for circadian rhythms and for

\footnotetext{
${ }^{7}$ Pittendrigh C. S. Circadian rhythms and the circadian organization of living systems // Cold Spring Harb Symp Quant Biol. 1960. V. 25. P. 159-184.

${ }_{8}^{8}$ Тимченко А.Н. Основы биоритмологии: учебно-методическое пособие / А.Н. Тимченко. - Х. : ХНУ имени В.Н. Каразина, 2012. - 148 с.
} 
fluctuations in parameters related to the sleep - wake cycle, such as body temperature, blood pressure, and urine production? ${ }^{9}$.

Taking into account circadian rhythms helps to understand the mechanisms of exacerbations of chronic diseases. The diagnosis and treatment are often more successful if the doctor understands and considers the role of circadian rhythms in the pathogenesis of diseases. So, in the early morning hours platelet aggregation is accelerated - at the same time, there is the highest probability of myocardial infarction, sudden cardiac death, stroke - the leading causes of death in the United States.

The results of diagnostic tests depend on the time of day - for example, indicators of blood pressure, temperature, samples with dexamethasone, plasma cortisol level. Few doctors realize how much even the simplest measurements depend on what time they were taken and what condition the patient was in - sleeping or awake.

During the day, the effectiveness and toxicity of medications changes. The effectiveness of chemotherapy and especially the effectiveness of the action of anesthetics, depend on the time of the drug administration.

And finally, the time of day determines the risk of accidents, the cause of which is insurmountable drowsiness. Traffic accidents, errors and industrial accidents most often occur in the second half of the night, when the need for sleep is maximum ${ }^{10}$.

Experienced travellers know well the effect of long-haul flights on circadian rhythms. When crossing several time zones, the synchronization of all human circadian rhythms is disrupted. And this violation of biorhythms persists until in the new time zone the cycles come into line with the daylight hours. This usually takes several days ${ }^{11}$.

It is the influence of long-distance flights on the well-being of travellers that made us think that, despite the obvious and proven endogenous nature of the dominant circadian rhythms, there is also some external additional "timer" of the circadian rhythm in living organisms. Indeed, light and dark time of the day, in addition to different levels of illumination and different values of the ambient temperature, have other differences too. For example, on the sunny side of the globe, the distance

\footnotetext{
9 Тимченко А.Н. Основы биоритмологии: учебно-методическое пособие / А.Н. Тимченко. - Х. : ХНУ имени В.Н. Каразина, 2012. - 148 с.

${ }^{10}$ Тимченко А.Н. Основы биоритмологии: учебно-методическое пособие / А.Н. Тимченко. - Х. : ХНУ имени В.Н. Каразина, 2012. - 148 с.

${ }^{11}$ Доскин В.А., Лаврентьева Н.А. Ритмы жизни. - М.: Медицина, 1991. - 176 с.
} 
from the earth's surface to the ionosphere is about 60 kilometres, and on the night side of the globe, this distance is about 400 kilometres. It is the variation of the distance from the earth's surface to the ionosphere, in our opinion, that can have a significant effect on the interaction between the earth's surface and the ionosphere. Approximately the same thing happens when playing a musical instrument - trombone. As the trombone lengthens, the sound becomes lower. As the trombone is shortened, the sound becomes higher. This happens due to resonance, which directly depends on the length of this musical instrument. By analogy, if the distance between the Earth's surface and the ionosphere changes, then the frequency of the electromagnetic effect should also vary. Since the resonant electrical interaction between the ionosphere and the earth's surface is possible exclusively in an open electrical circuit due to variable electromagnetic effects, the mechanism of this interaction cannot be based on any other effect than the conduction effect of a phonon or electron gas, which has already been successfully described in modern literature ${ }^{12}$.

The peculiarity of the reflection of the electromagnetic signal from the Earth's ionosphere is better, the greater is the wavelength of the transmitter. And according to the observations of radio engineers, the most stable radio communication with the effect of reflection of the radio wave from the ionosphere is communication in the long-wave range. But it is precisely in this range that the well-known and thoroughly studied medical equipment used since the end of the 19th century - darsonvalizers devices for inductotherapy - work. That is, empirically, based on many observations, for more than a hundred years in practice, inductotherapy devices have been used to correct disorders that are almost completely similar to circadian rhythm disorders in people.

Given that the activity of the human body is minimal at night, when the distance from the earth's surface to the ionosphere will be the most significant, we suggested that one should start observing the effect of an external sedative electromagnetic signal on the human body from the very beginning of the long wavelength range. The lower limit of the long wavelength range corresponds to a frequency of $140 \mathrm{kHz}$. As the distance from the earth's surface to the ionosphere decreases, as the terrain approaches the midday part of the ionosphere by the process of earth

\footnotetext{
12 Федорич А.В. Современные способы сохранения и восстановления здоровья. // Актуальні проблеми здоров'язбереження в молодіжному середовищі ХХІ століття. Тези доповіді. - Київ. - 2013. - С. 9.
} 
rotation, the frequency of interaction between the earth's surface and the ionosphere will increase. It is like in a trombone. It turns out that the stimulating effect on the midday part of the earth's surface will have a frequency which is several times higher ${ }^{13}$.

\section{The study of the impact on living organisms}

Darsonvalization is a therapeutic effect with a high-frequency pulsed current $(110 \mathrm{kHz})$ of $25-30 \mathrm{kV}$ voltage in the form of a series of oscillations of $100 \mu \mathrm{s}$ duration, followed by a frequency of $50 \mathrm{~Hz}$. This method is named after its creator - the French physiologist and physicist d'Arsonval. In local darsonvalization, the current is supplied through a glass vacuum electrode, moved along the surface of the body powdered with talcum, along the mucous membrane of the oral cavity, hairy part of the head, or through a special electrode inserted into the rectum ${ }^{14}$.

Under the influence of darsonvalization, blood vessels expand, blood circulation is activated, tissue nutrition improves. The method is used for varicose veins, for anal fissures, Raynaud's disease, the consequences of frostbite, long-term healing wounds and trophic ulcers, neurodermatitis, accompanied by itching, periodontal disease, chronic gingivitis, neuralgia, as well as cosmetology. Contraindications: malignant neoplasms, fever, bleedings, active pulmonary tuberculosis. For procedures the apparatus "Iskra-1" is used".

General darsonvalization, or induction therapy, in which the entire body is affected with an alternating magnetic field that induces weak eddy currents, is not currently used. Presumably, as we consider, for the reason that induction therapy devices are too bulky and require considerable effort to comply with safety requirements.

Darsonvalization is the general name for electrotherapy methods based on the use of an alternating pulse current or a high-frequency electromagnetic field. Local darsonvalization is the darsonvalization, which consists in exposure to individual parts of the patient's body with a weak pulsed alternating current of high frequency and high voltage. General darsonvalization (induction therapy) is the darsonvalization, which

\footnotetext{
13 Федорич О. Об'єктивні характеристики параметрів оточуючого середовища, що спричиняють патогенність ландшафту. // П 84 Професійний успіх у контексті стратегії сталого розвитку: освіта, економіка, екологія : [упорядн.: Н.О.Терентьєва ; Л.Г. Горяна]. - Черкаси : Видавець Чабаненко Ю.А., 2018. - С. 321-350.

${ }^{14}$ Ясногородский В.Г. Электротерапия. - М., 1987. - С. 114.

15 Ясногородский В.Г. Электротерапия. - М., 1987. - С. 114.
} 
consists in exposing the whole organism of the patient to a weak, highfrequency pulsed electromagnetic field.

For further study, we used a device of sparing inductance of our own design "Vitalizer" (tm), tuned to sedation (the frequency of the lower boundary of the long wavelength range). The peculiarity of this device is its compactness and insignificant output of high-frequency signal to the environment (to fulfil the requirements of hygienic standards) ${ }^{16}$.

The method of sedative induction therapy was invented by us in 2017 on the basis of the known and practiced medicine (physiotherapy) method of general darsonvalisation. The difference between the known method of general darsonvalisation and the innovative method of darsonvalisation lies in the fact that the latter, in contrast to the known method of induction therapy, takes into account the direction and spatial orientation of highvoltage electrical processes occurring in darsonvalisers.

The main effector difference between the torsion darsonvalization method and the known method is significantly stronger than its effect on biological objects. Depending on the orientation of high-voltage processes in space, this effect can be both stimulating and depressing. Previous studies conducted in this direction have shown quite interesting, in our opinion, results. In particular, a correlation of the effect of the torsional darsovalisation method on the elimination of cardiopulmonary failure in elderly dogs was found. In addition to the significant animal health effect, we have received a number of positive side effects for plants growing in the targeted area. The main side effect was that, within a radius of up to 10 meters from our units, which switched on 1 or 2 times a day for 60 minutes, indoor and outdoor plants began to develop much better than they had previously done in normal environments ${ }^{17}$.

The main provisions of the "hypothesis of the external electric drive of capillary circulation in plants"

1. Capillary flow in plants is due to external electrical influences in open electrical circuits.

2. An external electric drive of capillary current in plants is caused by vibration of the high-frequency range (darsonvalizers).

\footnotetext{
16 Федорич О.В., Дяченко О.П. Патент України на корисну модель № 132333 «Аппарат щадної індуктотерапії». 25.02.2019 p.

17 Федорич О.В., Дяченко О.П. Презентація винаходу - апарату дарсонвалізації «Антистрес». // Програма XIX міжнародного «Тижня освіти для дорослих» в Україні: «Життя є освіта». - 2018. - С. 13.

18 Федорич О.В., Дяченко О.П. Презентація винаходу - апарату дарсонвалізації «Антистрес». // Програма XIX міжнародного «Тижня освіти для дорослих» в Україні: «Життя є освіта». - 2018. - С. 13.
} 
3. Vibration of electricity in the environment affects all cellular, molecular and submolecular structures (ions) that have an electric charge and makes them oscillate.

4. The capillary flow in plants becomes directional due to the presence of valves in the capillaries of the plants. Valves (as in an electric pump) give a linear direction to the vibratory movement of the fluid.

5. The stronger such an electric external drive is, the better the plants develop (equatorial zone, tropics, subtropics).

6 . The weaker is the electrical external drive of capillary flow in plants, the worse will be the development of plants (polar latitudes, orbital space stations).

7. Natural processes on the external electric drive of capillary flows in plants can be simulated by technical devices.

8. Thanks to specially created technical devices, it is possible to improve significantly the performance of greenhouse crop complexes located in temperate or polar latitudes, as well as at space stations. It is theoretically possible to bring the productivity of greenhouses to the one possible only in tropical latitudes.

9. The external electric drive of capillary flows in plants, in our opinion, makes it possible to operate a natural "air conditioner" - a mechanism for cooling the topsoil in forests. The root system of the trees thanks to the external electric drive absorbs a lot of water, and the relative dilution of moisture around the roots (due to the pumping of water around the root system of the plants) creates a cooling effect (by the principle of air conditioning). Understanding these processes makes one think that global warming of the planet is mainly due to the deforestation of tropical vegetation.

Such devices in all versions increase the intensity of capillary flows in all forms of life, have a very powerful effect on the cardiovascular system (analeptic) and, due to increased drainage functions of the body, increase the intensity of specific and non-specific factors of the body's defence.

Subjectively, the influence of the apparatus is determined by the similarity of the feeling of being in tropical or subtropical latitudes. The mood and well-being increase. Plants within the radius of exposure of the apparatus develop as they do in the tropics.

In addition, our innovative method of induction therapy eliminates the massive metal (copper) cell in which a traditional induction therapy session 
is performed. This circumstance makes it possible to use inductive therapy without the need for special stationary and very expensive equipment. Also, our equipment consumes far less electricity for its operation.

\section{The sparing inductotherapy device "Vitalizer" (tm).}

Previously, we have had a fairly successful experience in using a sparing inductotherapy device to produce a stimulating effect. The presentation of our device at the "Sikorskyi Challenge" All-Ukrainian Start-up Competition brought us the diploma of the winner of this competition. The device artificially causes in the environment effects similar to the same natural processes in tropical and subtropical latitudes:

- it has a strong calming and harmonizing effect on emotional state;

- it significantly increases capillary circulation, which promotes the elimination of toxins and latent infections, adds stamina, eliminates trophic disorders;

- removes auto-toxins from tissue depots, leading to autoimmunization against own toxins and memory molecules of past diseases;

- It normalizes blood glucose levels (in a few weeks) by cleansing the insulin receptors from the protein "lute".

The range of action of the device when exposed to emotional state is 5-7 meters. Such devices in all variants of performance increase the intensity of capillary flows in all life forms have a very powerful effect on the cardiovascular system (analeptic) and by enhancing the drainage functions of the body increase the intensity of specific and nonspecific factors of body protection. The subjective influence of the device is determined by a sensation similar to being in tropical or subtropical latitudes. Mood and well-being increase ${ }^{19}$.

The devices are limited in their power of influence. They consume no more than 60 watts from the power supply network. And the power of their radiation does not exceed 20 watts. The range of coverage of such devices is about $8 \mathrm{~m}^{20}$.

The stimulus device was tuned to the middle of the long wave range of radio waves. We tuned the device for sedation to the lower limit of the

\footnotetext{
19 Энергоиммунология и ее практическое применение в теории медицины, гомеопатии и биоэнергетики [Текст] / В.Н. Федорич, А.В. Гаевская, А.В. Федорич [и др.]. - Ужгород : Патент, 2011. $232 \mathrm{c}$.

20 Федорич О.В., Дяченко О.П. Презентація винаходу - апарату дарсонвалізації «Антистрес». // Програма XIX міжнародного «Тижня освіти для дорослих» в Україні: «Життя є освіта». - 2018. - С. 13.
} 
long wavelength range. The power of energy of our devices does not exceed hygienic norms $\left(10 \mu \mathrm{W} / \mathrm{cm}^{2}\right)$ at a distance of more than half a meter from the body of the device.

Elderly people feel more comfortable when they receive sessions with the "Vitalizer" device at least twice a day. They feel much better and complain less about pain. We explain these effects by optimizing capillary circulation. The effect of improving the condition in patients with diabetes is interesting. The relief comes after 4 weeks of daily procedures and continues until the patient at least a couple of times a week conducts sessions with the "Vitalizer" device. We explain these effects by cleaning the membrane structures of the macro-boundary layer from the amyloid "lute" on its surface. Likewise, the cleaning of membrane structures causes effects similar to those of homeopathic treatment: improvement after a short-term exacerbation ${ }^{21}$.

In all cases, the instrument was switched on for 60 minutes twice a week. The distance between the volunteers and the instrument was 2-3-4 meters.

\section{Investigation of the device influence on appetite}

A group of students of V.I. Vernadskyi Taurida National University, consisting of 15 young people, voluntarily participated in the trial of the device for sedation inductotherapy.

During the facultative classes with the teacher, students participating in the experiment received a session of sedative inductotherapy. During the sessions of inductotherapy, the participants of the experiment were asked to note their emotional state and overall well-being.

The experiment lasted three calendar months. In total, participants who took part in the experiment received 27 sessions of sedative induction therapy. In this group for three months twice a week for an hour the device was switched on for sedation inductotherapy. The device was about 3 meters away from volunteers. That is, the existing hygienic standard of microwave load $\left(10 \mu \mathrm{W} / \mathrm{cm}^{2}\right)$ was not violated.

All the participants in the experiment carried out control weights to determine their body weight. Twice a week, in the morning on an empty

\footnotetext{
21 Федорич О.В., Дяченко О.П. Презентація винаходу - апарату дарсонвалізації «Антистрес». // Програма XIX міжнародного «Тижня освіти для дорослих» в Україні: «Життя є освіта». - 2018. - С. 13.
} 
stomach, they carried out control measurements of their body weight on the same stationary medical mechanical scales RP-150MG.

A description of the emotional and objective state of the group of people taking part in the experiment, depending on the conducted inductotherapy session, is given in the table:

Before the experiment, all volunteers were examined by a doctor and passed general blood and urine tests for the purity and safety of the experiment. After the completion of the experiment, the same examinations and analyses were repeated. The repeated studies did not reveal deterioration in the health of the experiment participants. During the experiment, all its participants led their usual way of life and did not change their diet and taste preferences. Some participants in the experiment ( 9 persons) noted that they had become less susceptible to respiratory diseases - characteristic of the demi-season, in which our experiment ended. And 12 participants in the experiment noticed that they became noticeably calmer and more balanced.

Over the three months of this experiment, the volunteers lost an average two kilograms and two hundred grams of weight. At the same time, 12 out of 15 volunteers noted a significant sedative effect of the apparatus for sedative inductotherapy. This sedative effect manifested itself in volunteers simultaneously after 9 weeks of the test exposure.

\section{CONCLUSIONS}

The results received by us clearly indicate that the circadian rhythms of a person do not depend only on the level of sunlight and ambient temperature.

Bionic imitation of the natural interaction between the Earth's surface and the ionosphere at night led to a pronounced sedative effect, which was also objectively confirmed by a decrease in the weight of all the participants in our experiment.

The main conclusion of our experiment is that the imitation of the natural interaction between the Earth's surface and the ionosphere, characteristic of the night-time distance between the Earth's surface and the ionosphere, carried out in the daytime for a group of volunteers, leads to a significant sedative effect.

Such a sedative effect can be effective to reduce appetite and gradually normalize excess body weight. And the mechanism of this effect 
is also directly related to the external biospheric mechanism of influence on the endogenous mechanism of human circadian rhythms.

\section{SUMMARY}

As a result of studying the effect of sedative induction therapy on the appetite of a group of volunteers, it was found that this method allowed reducing the body weight of the people who participated in the experiment, without changing their lifestyle, eating habits and preferences.

Such a reflex effect of the sedative inductotherapy method on the appetite of the participants in the experiment is most likely due to the fact that the equipment for the implementation of the sedative inductotherapy method imitates natural electromagnetic phenomena and processes that affect the regulation of human circadian rhythms.

\section{REFERENCES}

1. Агаджанян Н.Л., Губин Г.Д., и др. Хроноархитектоника биоритмов и среда обитания. М. - Тюмень: изд-во Тюменского гос. ун-та, 1998. 168 с.

2. Алякринский Б.С., Степанова С.И. По закону ритма. - М.: Наука, 1985. - 175 с.

3. Губин Г.Д., Герловин Е.Ш. Суточные ритмы биологических процессов и их адаптивное значение в онто- и филогенезе позвоночных. Новосибирск: Наука, 1980. 277 с.

4. Дильман В.М. Большие биологические часы. - М.: Знание, 1986. $-256 \mathrm{c}$.

5. Доскин В.А., Лаврентьева Н.А. Ритмы жизни. - М.: Медицина, 1991. $-176 \mathrm{c}$.

6. Мошкин М. П. Влияние естественного светового режима на биоритмы полярников // Физиология человека. 1984. Т. 10. № 1. С. $126-129$.

7. Федорич О.В., Дяченко О.П. Патент України на корисну модель № 132333 «Аппарат щадної індуктотерапії». 25.02.2019 р.

8. Энергоиммунология и ее практическое применение в теории медицины, гомеопатии и биоэнергетики [Текст] / В.Н. Федорич, А.В. Гаевская, А.В. Федорич [и др.]. - Ужгород : Патент, 2011. - 232 с.

9. Энергии жизни: современное понимание древних представлений о Вселенной [Текст] : монография / А.В. Федорич, 
Н.В. Слухай. - Изд. 2-е, испр. и доп. - Ужгород : Патент, 2013. 136 с. : ил. - ISBN 978-617-589-064-6

10. Федорич А.В. Современные способы сохранения и восстановления здоровья. // Актуальні проблеми здоров'язбереження в молодіжному середовищі XXI століття. Тези доповіді. - Київ. - 2013. - С. 9.

11. Федорич О.В. Гігієна біополя у контексті глобальних ризиків. // Програма XVII міжнародного «Тижня освіти для дорослих» в Україні: «Татусь - мій навчитель». - 2016. - С. 14.

12. Федорич О. Об'єктивні характеристики параметрів оточуючого середовища, що спричиняють патогенність ландшафту. // П 84 Професійний успіх у контексті стратегії сталого розвитку: освіта, економіка, екологія : [упорядн.: Н.О. Терентьєва ; Л.Г. Горяна]. Черкаси : Видавець Чабаненко Ю.А., 2018. - С. 321-350.

13. Федорич О.В., Дяченко О.П. Презентація винаходу - апарату дарсонвалізації «Антистрес». // Програма XIX міжнародного «Тижня освіти для дорослих» в Україні: «Життя є освіта». - 2018. - С. 13.

14. Федорич А.В. Физический эфир и новая трактовка результатов эксперимента Майкельсона-Морли. // Проблеми інноваційноінвестиційного розвитку. № 10. - 2017. - С. 138-153. https://nonproblem.net/wp-content/uploads/2017/10/Stattya-18.pdf

15. Тимченко А.Н. Основы биоритмологии: учебно-методическое пособие / А.Н. Тимченко. - Х. : ХНУ имени В.Н. Каразина, 2012. - 148 с.

16. Ясногородский В. Г. Электротерапия. - М., 1987. - С. 114.

17. Pittendrigh C. S. Circadian rhythms and the circadian organization of living systems // Cold Spring Harb Symp Quant Biol. 1960. V. 25. P. 159-184.

18. Wever R. The circadian multi-oscillator system of man // Int J Chronobiol. 1975. V. 3. N. 1. P. 19-55.

\section{Information about the author:} Fedorych O. V.

$\mathrm{Dr}(\mathrm{PhD})$ of Medical Sciences, Associate Professor at the Department of Physical Education,

Sports and Human Health of the V. I. Vernadsky Taurida University 33, Ivana Kydri str., Kyiv, 01042, Ukraine 


\section{PSYCHOLOGICAL ACCOMPANIMENT OF THE STUDENTS' HEALTH RECREATION PROCESS IN THE PSYCHOLOGICA FIELD}

\section{Kichuk A. V.}

\section{INTRODUCTION}

In the context of personality development psychology, adolescence (in particular, its second period, that is, 17-21 years) coincides with the stage of student status acquisition. Scientists mainly share the theoretical model of socio-normative periodization developed by D.I. Feldstein to emphasize the features of personality formation in the context of all stages of ontogenesis - from fixing self-identifications through self-affirmation to self-determination and self-realization ${ }^{1}$.

Among the many approaches that have developed in modern psychological science, scientists are of considerable interest to those that allow us to expand the boundaries of our "knowledge of ignorance." Especially when it comes to the multidimensional activity of modern man; there is no exception to the interpretation that in general life is from the point of view of psychology. In connection with the above, attention is drawn, in particular, to the scientific discussion regarding such "polar trends in the methodology of science" which are regarded (O. Gasmolov, O.D. Shekhter, O. M. Chernorizov) specialization and universalization of cognition $^{2}$.

The present day brings to the fore the eternal questions of human vitality, the central place of which is health (physical, social, psychological, spiritual).

Mostly, the phenomenology of health is studied as a subject of medical and social research. After all, according to the encyclopaedic interpretation, health is a natural state of the human body, characterized by poise in relation to the environment. The researchers, directly or indirectly studying the content-related characteristics of health, are still trying to

\footnotetext{
${ }^{1}$ Ермолаева М.В. Психология развития : учебное пос. - 3-е издание, стереотипное. - Москва : МПСИ ; Воронеж : МОДЭК, 2006. - 376 с.

${ }^{2}$ Маслоу А. Психология бытия. - К.: Ваклер, 1997. - 304 с.
} 
agree on a clear definition of a basic concept. Thus, the statute of the World Health Organization contains the following definition: "Health is a state of complete physical, spiritual and social well-being, and not just the absence of diseases and physical defects." In the context of psychological and pedagogical problems, various aspects of the physical, spiritual, social and psychological health of an individual are actively being studied. Therefore, the idea of the corresponding "flower petals" of a healthy person has already been formed. But even the fundamental developments of researchers on the phenomenology of health (Bilych G.L., Nazarova L.V., Popova S.V. and others) did not provide a universally recognized scientific position on the content of the concept of "health". For example, the convincing conclusions of the researchers include depriving the emphasis on the mainstream meaning of "well-being"; the importance of human ability to adapt to the environment; recognition a person to be healthy as one who has no diseases, physical defects; the appropriateness to see in health both qualitative and quantitative characteristics (recognizing that it is fundamentally important to measure its degree in terms of the breadth of the adaptive capabilities of the organism), etc. Of particular interest to health researchers is the scientific potential (in particular, of V.P. Kaznacheyev), where it is proved, on the one hand, the dynamism of a healthy state, and on the other, the importance of a person's ability to "optimal practice, social activity provided a maximum life span". P.I. Kalyu, as a result of the analysis of professional literature (which represents his work "Essential characteristics of the concept of "health" and some issues of restructuring health protection: overview information") comes to the conclusion that it is legitimate to distinguish between the most common concepts: medical, in which the leading a characteristic of health should be considered the absence of diseases and their symptoms; biomedical which recognizes the absence of a subjective feeling of "ill-being" - a basic parameter of health quality; biosocial, where social markers are recognized as the dominant features; value and social, according to which health is conceived as inherent value. The latter concept was determined by researchers as constructive for the context of studying the subject specifics of the social and humanitarian sciences (in particular, psychology - experimental, social, health psychology, 
developmental psychology, pedagogical psychology), in terms of human behaviour which is connected with his or her health ${ }^{3}$.

Despite the scientific research on the phenomenology of health available in psychological science, there is still a lack of consistency in scientific ideas about the psychological health of a person at different stages of ontogenesis.

Of fundamental importance for our study, we regard the position of O. Khukhlaueva, who believes that since a person builds relationships based on subjective experience, it is precisely at the age of 23-25 years old that he or she "receives" this access given the acquired spiritual powers and opportunities, and this "gives him or her an opportunity to carry out spiritual activity" ${ }^{4}$. An attempt to determine the basic characteristics of a student personality's psychological health in particular, makes notable O.S. Shtepa's studies. The researcher refers psychological resourcefulness, which was interpreted through a person's spiritual abilities, to those revealing the "individual's life-purpose experience and the value-based attitude to others", 5 .

Therefore, we can assume that it is in the indicated age period that a personality acquires the ability to reveal the nature of his or her own relations with the environment, to determine the position in relation to the "not-Self", that is, to others.

It is known that the basic idea of both existential and humanistic psychology is the recognition of subjective activity as an internal determinant of human life. Therefore, it can be assumed that psychological health acts as a parameter of "value" and "sense". The latter, in the context of axiological problems, for example, B. Bratus' specifies with a "personality's semantic sphere" construct. O. Ball - with a "semantic mindset", V. Chudnovskyi - with the "optimal sense of life", D. Leontyev with " life-purpose orientation", V. Frankl - with "sense creating activity", Leontyev - "personality sense". At the same time, despite the diverse accents in the conceptual interpretation of the value-semantic determination of human life, it is completely obvious that we are talking about a possible measurement of its psychological health, making up the

\footnotetext{
3 Бочавер А., Ступак Р. XXIV Европейская конференция по психологии здоровья «Здоровье в контексте». Психологический журнал. - М.: Наука, 2011. Т. 32, вип. 2. С. 116-118.

${ }^{4}$ Хухлаева О.В. Психология развития: молодость, зрелость, старость. - М.: Изд-ий центр «Академия», 2002. $-208 \mathrm{c}$.

5 Штепа О.С. Особливості психологічної ресурсності осіб 20-25 років з різним статусом ідентичності // Наука і освіта. - 2013. - № 7. - С. 204-208.
} 
subjective indicators. And the latter is related to attitude; it realizes an incentive function and performs a regulatory role regarding the behaviour and manifestation in all sorts of human activity.

In the outlined perspective, the philosophers' opinion that precisely values are decisive in the "upper boundary of an individual's social claims" seems interesting to us".

So, the axiological approach acquires exceptional explanatory value in the process of deepening of scientific ideas about the phenomenology of an individual's psychological health in the corresponding age period, of course, taking into account the established ones (O. Zdravomyslov, Z. Karpenko, G. Rikker, M. Rokych, M. Chavchavadze and others) dominants of this approach. In our understanding, its constructiveness is also associated with the potential of integrating the natural science and humanitarian methodologies. That's why we see important guidelines for expanding established ideas about the psychological health of an individual in A. Maslow's methodological value position that "moving towards the psychological health of an individual means approaching a society based on spiritual values, approaching social harmony"7 as. The foregoing sets methodological guidelines for the selected research approach.

\section{The psychological health of adolescent personality as a subject of modern scientific knowledge}

The analysis of both reference and special literature testifies to the interconnection of the concepts of "health" and "individual meaning of life". Researchers (O.O. Korolkov, V.F. Serzhantov) have proved that it is advisable to proceed from the characteristics of the "personality health model." In their opinion, structurally, such a model is represented, firstly, by the attitude of a person to his or her own body; secondly, the personal degree of understanding of health and conservation goals; thirdly, knowledge of the laws of the functioning of the body and the degree of volitional regulation; fourthly, one's own attitude to diseases, the level of activity aimed at overcoming a diseased state; fifthly, the expressiveness of motivation in the healing process. Therefore, based on the personal model of health, we can assume the nature of strategies and tactics produced by a person during his life's journey.

\footnotetext{
${ }^{6}$ Кремень В.Г. Освіта має визначити розвиток духовності й культури //Креативна педагогіка. - 2011. № 4. - C. 11-12.

${ }^{7}$ Маслоу А. Психология бытия. - К.: Ваклер, 1997. - 304 с.
} 
A somewhat different research approach is proposed by S.Ya. Chykyn and G.I. Tsaregorodtsev, in particular, believing that health is a manifestation of the integrity of the individual. Such position coincides with our understanding of the origins of a special state of personality psychological health. So, the scientists by the context of "health" for a reason consider a "norm" and "disease", stating the following: it is impossible to reduce health only to a physical state. This position has been recognized in psychological science and practice ${ }^{8}$ through the approval of the imperative $f$ the equally important role of psycho-emotional equilibrium, the latter being understood as a person's "psychological health". At the same time, the researchers highlight the etymology of the English word "health", which comes from the Anglo-Saxon word "whole", and some of them (in particular, Yu. Dorovantu, Z. Pavdid, P. Penchu) affirm that it is appropriate to consider health to be the quality of life, recognizing the interconnectedness, interdependence and intercondi-tionality of the individual's physical condition, his mental manifestations, emotional reactions and the life social environment; moreover, it is affirmed that the personality's behavioural model "adapts" to a harmonious and integrated set of relationships and influences between the individual and society.

The analysis of scientific sources shows that in scientific vocabulary the term "psychological health" is often replaced by others. If we analyse the thesis researches, then there is a ground to note that it is said about a "norm" and a "pathology" (Dushka O.O.), a personality's stress resistance (Korolchuk O.M.), psychological well-being (Oleksandrov Yu.M.).

As a result of the analytical work done, it has been found out that some of the problematic issues of psychological health and the author's vision of their solution contain O.V. Zavgorodnya's developments. We consider the researcher's position to be constructive, in particular in such perspectives:

- the outline of the content of the "psychological health" concept represented by: a high level of formation of conscious self-regulation, rational-volitional sphere; these components provide both the possibility of a person's social adaptation, as well as a "free underpressed state of the emotional sphere", activity of mental processes unconscious by a person; his or her ability to deep feelings and intuition is based on the outlined components;

\footnotetext{
${ }^{8}$ Психология здоровья / Под ред. Г.С. Никифорова. СПб: Питер, 2003. 607 с.
} 
- implementation of the revision of the concepts of "mental" and "psychological" health: psychological health becomes possible with the availability of mental health; contradictions are possible between the designated phenomena despite their relative autonomy;

- providing the psychological health of a person with the characteristics of a dynamic process - firstly, due to the interpretation of the said personality neoplasm as a "dynamic integrity", secondly, insisting on such a characteristic of a psychologically healthy person as the "pulsation" of harmonious and disharmonious states; thirdly, illustrating the trajectory of movement in this way: a psychologically healthy person combines certain features of the mentally normal (in the traditional sense) and the features that are not characteristic of this person (vulnerability, activity of unconscious mental processes, the ability to deep feelings) which "under certain conditions" can lead to mental destabilization",;

- determination of the criteria for the psychological health of a person, irrespective of age specifics, namely: a sensitive-interested attitude to one's own identity and other living beings; pronounced cognitive and creative activity; self-motivation and constructiveness of life practice; beneficial effects on the environment;

- The attempts to determine the scientific status of the "psychological health" concept through the construct "psychological ill-being", the originality of which is associated with a person's choice of a passive life strategy.

It is obvious that the implemented study broadens the established understanding of the phenomenology of human psychological health through the definition of new outlines of this phenomenon, as well as the search for the limits of intersection with mental health, emphasis on measurements, at which certainty in the diagnostic tools is possible.

However, despite a completely obvious productivity of O.V. Zavgorodnodnya's research position of, we nevertheless agree that in this position the interpenetration of two different phenomena is quite clearly traced psychological health and moral health. The researcher claims the following: "we distinguish between the concepts of "psychological health" and "personality maturity", although we consider them interrelated; "Psycho-

\footnotetext{
9 Завгородня О.В. Питання збереження психологічного здоров'я: визначення, критерії, умови збереження. 2006. № 3(52). С. 87-96.
} 
logical health is the pre-condition of achieving personal maturity, and personal maturity contributes to the preservation of psychological health", ${ }^{, 10}$.

In connection with the aforementioned, those scientific approaches that have explanatory power on such a complex phenomenon as the psychological health of an individual appear to be of great research interest. O.V. Shuvalova's point of view seems convincing to us, who claims that it is appropriate to think over this personality state simultaneously in the perspective of two approaches: person-cantered and sociocentric; this is motivated, on the one hand, by the obvious intersection of such approaches in explaining the spiritual value of a person, and on the other, by helping to develop an "anthropocentric standard of health". Therefore, the researcher notes not without reason that psychological health acts as a state that characterizes the process and result of the "normative development of subjective reality within the framework of individual life" ${ }^{\text {"11 }}$. In addition, we consider to be substantial the following clarification made by O.V. Shuvalov: the "maximum" of psychological health is the integral - unity, completeness and integrity - of the vitality and "humanity" of a personality.

Our interest was the age period of a personality at the stage of acquiring professional identity by him or her, namely - in higher school conditions. The outlined plane of comprehension of the above-mentioned aspect of the problem of psychological health of a personality is conditioned, on the one hand, by the specificity of the influence of the educational process and its educational and professional activity on the relevant components of the determined personal property; on the other hand, the analysis of numerous empirical data obtained by researchers (in particular, Havrylyuk I., Kuznetsova O., Ryabchenko N. - Ukraine; Perera H., Mcilveen P., Oliver M. - Australia; Deasy C., Coughlan B., Pironon J., Jourdan D., Mannix-McNamara - Ireland; Enns A., Eidridge G., Montgomery C., Gonzalez V. - the USA), regarding the psychological health problematic field of today's student youth.

So, in our opinion, the structural and component composition of "psychological health" concept and the uniqueness of certain components of such a personal characteristic (like the emotional component) becomes more

\footnotetext{
10 Завгородня О.В. Питання збереження психологічного здоров'я: визначення, критерії, умови збереження. 2006. № 3(52). С. 87-96.

11 Шувалов А.В. Гуманитарно-антропологические основы теории психологического здоровья. Вопросы психологии. 2004. № 6. С. 18-33.
} 
fully possible under the conditions of "specificity" of age. This acquires special significance, since many problematic issues of modern psychology are directly or indirectly associated with the "biological - psychological social" plane by researchers, and when it comes to a multi-aspect and multilevel psychological phenomenon, it is recognized that, as a rule, the development of any phenomenon does not stop during life, is not formed in a certain age period of a person once and for all. For example, setting the goal to explore the processes of gender identification and the formation of gender identity in the ontogenesis of an individual, researchers emphasize the importance of choosing a healthy gender-role behaviour ${ }^{12}$.

On the whole, it can be assumed that despite the importance of being aware of those personality neoplasms that are caused by the specifics of his or her age (M. Akimova, I. Dubrovina, V. Voytenko, V. Karpenko, A. Khlivna, etc.), there are still grounds to admit that the boundaries of a personality's age who identifies himself with the status of students, are relative and conditional. This is caused by an objectively existing circumstance, because a personality realizes his or her intention to become a student depending on the age period when the decision about professional choice is made. To the abovementioned let us add that, based on the nature of such a phenomenon which appears to be psychological health of a personality in student years, it is expedient to conceive it by its basis - the sovereignty of psychological space. As the researchers note, it makes sense to consider psychological sovereignty not only as a condition, but also as a result of adaptability, maturity and productivity of a person; moreover, such "harmonious success" uses the "language of the environment" - the language of "the interaction of individuality and society" ". Therefore, it is possible to assume that the state of psychological health of the student's personality is a kind of indicator of "control" and "self-control".

\section{Taking into account the emotional determination of students' psychological health is recreational psychology imperative}

Psychological health determinants are still the subject of scientific discussion, a personality's psychological health acts as a holistic entity which involves a certain balance of properties and processes. Therefore, it

\footnotetext{
12 Кікінеджі С. Гендерна ідентичність в онтогенезі особистості: монографія.-Тернопіль: Навч.книгаБогдан, 2011. - $400 \mathrm{c.}$

13 Гаврилюк I. Емпірична експлікація суверенності психологічного простору в показниках соціального контролю особистості // Психологічні перспективи. - Вип.33. - Луцьк, 2019. - С. 49-65.
} 
makes sense to perceive in a personality's health in the psychological sphere a dynamic personal property. We share the opinion of researchers who note the usefulness in the outlined psychological phenomenon to distinguish between the hierarchy of certain levels, in particular, from the perspectives of "mental", "subjective" and "individual". Given the abovementioned, as claimed by T.D. Dancheva, it is advisable to distinguish several levels of psychological health of a personality. In particular, at the mental level, the educational system also acquires the actualization of personality, on the subjective - vitality, and on the individual - adaptability ${ }^{14}$.

In our understanding, the personality's psychological health acts as his or her integrative property, where exactly the emotional component has comprehensive and systemic role. The fact is that all sections of psychological science are connected with emotions; this phenomenon also permeates any personality's activity, penetrating into psychological processes. S.L. Rubinstein's opinion is perhaps the most authoritative in this regard: "The point is not that emotion is in unity with intellect or thinking with emotion, but that thinking itself as a real psychological process is already the unity of the intellectual and emotional, and emotion is the unity of emotional and intellectual" 15 .

Scientists who study certain vectors of the personality's emotional sphere (Emons P., Kyrylenko T., Lushin P., etc.), are unanimous in recognizing the fact that it is in emotions that one recognizes through experience both the significance of the environmental phenomena and the weight of "one's own". In addition, a positive correlation between emotional intelligence and personality openness to interaction in interpersonal relationships has been established (Caruso D., Meyer J., Myloslavska O., Solovey P., etc.). Therefore, the researchers conclude that emotional intelligence, as a psychological phenomenon is directly related to the personality's friendliness.

The founders of the emotional phenomena psychology (Vilyunas V.K., Grat N.Ya., Isard K.E. and others) have proved that they have a dual character, as well as the peculiarity of the colour with which the subject reflects. At the same time, in connection with the comprehension of the emotional component of the psychological health of the personality, we

\footnotetext{
14 Данчева Т.Д. Типология психологического здоровья личности // Наука і освіта, 2012. - № 3. C. $50-54$.

${ }^{15}$ Рубінштейн С.Л. Проблеми загальної психології. - М.: Педагогіка, 1973. - 424 с.
} 
also consider such comments important. Firstly, emotions act as one of the forms of existence of personal sense; moreover, it has been proved that both systems of terminology - "emotional" and "semantic" - in psychology "describe" the same phenomenon, are interchangeable, although "sense" has a more explanatory character, and "emotions" are descriptive ${ }^{16}$. Secondly, emotional phenomena have an "external" effect on the general course of the psychological process through the functions they perform (emphasis, memory, synthesizing, inducing, creating an "affective trace"), which are interrelated.

The abovementioned, of course, affects the basic dimensions of health in general: as a fact, as a norm, as a value, as an object of scientific knowledge. In addition, the indicated construct acquires certain specificity, taking into account both the interpretation of the personality and the level characteristic of his or her development. As regards the latter, according to S. Maksymenko, at least three levels should be distinguished, namely: on the first level, the reflection of one's own inner world is absent, on the second - events are already planned by the personality and their consequences are predicted, their own environment is formed, and on the final level the subjective measurement of not only one's own life path takes place, but also of one's own inner world ${ }^{17}$. At this, experience is recognized as the "correlate of the existence of the inner world"18. Therefore, the specified forms an explanation of the origins of psychological health emotional characteristics as an integrative personality characteristic. Indeed, modern reference sources define experiences both as an emotionally coloured state of a subject, and as an internal signal with which a person "realizes the personal significance of events", and as a form of subject activity aimed at rethinking one's existence. Therefore, it seems possible to re-evaluate the importance of the fundamentally important remarks of scientists in relation to the specifics of emotional phenomena ${ }^{19}$. It is, firstly, about understanding the general and diverging in the "emotional" and "semantic": they describe the same phenomenon in psychology, and therefore are considered interchangeable; at the same time, it's still appropriate to understand that "sense" basically acquires an

\footnotetext{
${ }^{16}$ Вилюнас В.К. Психология эмоциональных явлений - М.: Изд-во МГУ, 1976. - 143 с.

${ }^{17}$ Максименко С.Д. Генезис существования личности - К.: Изд-во ООО «КММ», 2006. -240 с.

${ }_{18}^{18}$ Максименко С.Д. Генезис существования личности - К.: Изд-во ООО «КММ», 2006. - 240 с.

19 Чебикін О.Я. Становлення емоційної зрілості особистості: монографія / О.Я. Чебикін, І.Г. Павлова. - Одеса: СВД Черкасов, 2009. - 230 с.
} 
explanatory, and "emotional" - descriptive character. Secondly, the recognition of the scientifically established fact that emotional phenomena realize a specific function in the process of satisfaction by the subject of his needs - experiences, add "decorations" to the image of the needs surrounding the object and thereby "turning them into motives", (we are talking, according to Vilyunas, about leading emotional experiences or motivating ones), as well as about those experiences that arise already in the presence of leading motivations, originating in the process of internal or external activity. Therefore, - these indicated emotional phenomena express the personality's corresponding formation to the conditions of activity; scientists mark them as "derivatives" 20.

Taking into account the observations made by scientists, it seems fundamentally important to re-evaluate the fundamental groundwork in this regard for some representatives of classical psychology. In particular, we are talking about the work of N.Ya. Grot (1879), who was able to analyse the long-term experience of researchers (from the ancient Greek period to the 19th century) in the aspect of the dual nature of emotional phenomena and the drawbacks of reducing real emotions to subjective emotional experiences, and then, to investigate the specificity of the emotional component, in particular, in such a complex psychological phenomenon as personality's psychological health. We believe that the designated gets considerable significance given the position among researchers regarding the understanding of the emotional segment and the mental (not psychological) one in particular, of students' health specifically. In an attempt to determine the problematic issues related to the emotional segment of the psychic as a "qualitatively new, non-world-complex system", we relied on the scientific achievements of O. Prokhorov, where the category "mental state" appears in the format of the unity of the subject's experience and his or her behaviour (deeds, actions, reactions); moreover, the scientist, while considering experiences as a basic characteristic of a mental state, differentiates experiences, emotions and feelings, considering the former much broadly than the latter ${ }^{21}$, because experiences are not limited to the affective sphere, but are connected with the activity that induces them, with everything that is conditioned by psychological experience. In this perspective, the proposed three-chain

\footnotetext{
${ }^{20}$ Вилюнас В. К. Психология эмоциональных явлений - М.: Изд-во МГУ, 1976. - 143 с.

${ }^{21}$ Прохоров А.О., Валиуллина М.Е., Габдреева Г.Ш., Гарифуллина М.М., Менделевич В.Д. Психология состояний: Уч. пос. / Под ред. А.О. Прохорова. - М.: Изд-во «Когито-центр» - 623 с.
} 
system of determination of mental states ("personality - situation personal meaning") is notable for constructiveness because the life activity situation is considered as the main reason that stimulates the mental state, and, using psychological terms, the functional structure "affect + emotions + feeling" reflects the function of psychics reactive regulation ${ }^{22}$. So, the researchers ${ }^{23}$ see at least the following things in the modern students' mental health: this category of Ukrainian youth (and according to the established empirical data, $18 \%$ of them) are characterized by overestimated indicators precisely in the context of "emotional psychological problems". To the abovementioned we shall add the following: the students' problems associated with the emotional sphere are referred to by researchers as "pathopsychological symptoms", and, detailing the results of American, Dutch and German scientists, they note empirical data on the already (and not mental) psychological health that are closest to the aforementioned students (in particular, a statement of the trend that every third student has reason to be classified as at risk of psychological maladaptation).

Therefore, in the plane of universally recognized by scientists, the exceptional importance of psychological health as a personal property, which is marked through weighty, key and cross-cutting parameters of a person at any stage of his or her life (for example, according to I. Dubrovina, is "an indicator of a person's normal development", and according to V. Lishchuk - "the most appropriate measure of individual and social development"), the theory of psychological health has not yet been developed. Academic science has not formed yet the generally accepted opinion about the system-forming phenomenon in the structure of psychological health as a complex personality formation, where emotional insensitivity is generally recognized as an indicator of a low level of manifestation.

Studying the issue of the emotional sphere as a whole causes increased interest in the works of those scientists who distinguish certain vectors in $\mathrm{it}^{24}$. We are talking about the relevance of studying the

\footnotetext{
22 Прохоров А.О., Валиуллина М.Е., Габдреева Г.Ш., Гарифуллина М.М., Менделевич В.Д. Психология состояний: Уч.пос. / Под ред. А.О. Прохорова. - М.: Изд-во «Когито-центр» - 623 с.

23 Карпенко В., Миколайчик М., Войтенко В., Мединська Ю. Сучасний стан психічного здоров'я студентської молоді : емоційна, міжособистісна та рольова сфери // Практична психологія та соціальна робота. - 2012. - № 11. - С. 2-8.

${ }^{24}$ Кириленко Т. Емоційна сфера особистості: вектори вивчення // Вісник Київського нац. ун-ту ім. Т. Шевченка. Психологія. - 2018. - № 1(8), - С. 26-29.
} 
emotional sphere of the psychics of a person to keep in the circle of research attention vectors such as: 1) the very creation of emotions and feelings (emotional exchange) 2) modality, the intensity of emotional experiences is a level sensitive manifestation; 3) emotional readiness of a person to change (emotional capabilities, emotional experience) 4) emotional self-knowledge (emotional intelligence, emotional competence as a person's ability); 5) spiritual experiences (such as mercy, sympathy, love, forgiveness). The outlined above guides the process of studying the personality's emotional sphere in general and the outline of the plane and the substantive content of this sphere in regards to students.

The study and generalization of the scientific heritage of scientists exploring the emotional world of a personality indicates, firstly, the appropriateness of distinguishing such a world in terms of its emotional typology (emotional, sentimental and passionate). So, it is recognized that the process of personality development, in fact, is a process of development of his or her feelings. And here it is important to speak mainly about the culture of the manifestation of one's own experiences, and not their containment. Indeed, the experience convinces: if unedited emotions accumulate, then with a high degree of probability it is possible to predict the disorganization of the personality in unexpected situations in life. And this, of course, affects his or her psychological health.

Secondly, about the appropriateness to distinguish by segments between romantic, altruistic, gnostic, active, communicative and aesthetic emotions and feelings by the state of the emotional sphere development (in particular, taking into account its emotional orientation). At the same time, it is considered important to take into account the probability of the existence of individuals with an undeveloped emotional sphere, who perceive the surrounding world as hostile, displaying an "unscrupulous position".

Thirdly, the generally accepted conclusion among psychologists is the conclusion that each person has precisely his or her own "emotional repertoire"; moreover, throughout life, a person is dominated by various emotional states (such as uplift, oppression, excitement, etc.), although it is advisable to consider such a form of emotions as mood an indicator of a person's temperament.

Taking into account even the aforementioned, an opportunity is already being created for determining at least two remarks: the emotional 
component of such a many parametric phenomenon as what appears to be psychological health is rightfully interpreted as one of the important ones; the preservation and optimization of the psychological health of the individual, in particular, the age stage of growing up, becomes possible only if the emotional and personal characteristics of it are taken into account. Therefore, the issue of the characteristics of the personality's psychological health emotional signs as well as those basic ones from their totality, which are characteristic of the state of health specifically to students in the psychological field, is being actualized.

Indeed, it is precisely through the emotions that a person finds sources of feedback with reality to determine his or her place in it; thanks to emotional contact with another, such a development mechanism as reflection is formed; outside of emotional contact, the "truth" of the transfer of moral experience becomes impossible. So, the abovementioned strengthens the theoretical and empirical significance of the process of researching precisely the personal emotional characteristics of psychological health. The imperative is the recognition of reduction of negative emotions but not the rejection of them.

In this context, an empirical study aimed at proving the importance of special emotional learning for students in a modern university ${ }^{25}$ attracts attention. In addition, the outlined was not considered by researchers as an end in itself, but to elucidate the indirect effect of critical thinking regarding self-regulation and social emotional learning of students. Thus, it has been experimentally established that the influence of self-regulation on the initiative of social emotional learning is mediated by the personality's critical thinking. Therefore, the acquired new data on the phenomenon of self-regulation - the ability to control oneself on the basis of and perception of one's own psychological states and behaviour - its influence (direct and indirect) on emotional learning ${ }^{26}$. Such a comment acquires great practical-oriented significance, because it allows you to direct a methodical search for accounting and the emotional and personal characteristics of students' psychological health in the process of their educational and professional activities in higher school.

\footnotetext{
25 Arslan S. Social emotional learning and self -regulation: The mediating role of critical thinking. International Journal of Learning and Change. 2018. 10(2), p. 101-112.

26 Arslan S. Social emotional learning and self -regulation: The mediating role of critical thinking. International Journal of Learning and Change. 2018. 10(2), p. 101-112.
} 
Thus, the results of the analytical work done allow us to state that it is legitimate to speak about certain outlines of the theory of psychological health of a personality during early adulthood, which corresponds to student age. The self-reflection of the experience of professional activity in higher school contributes to the direction of the systematization process of empirical studies established by psychologists, which contain new psychological facts regarding the uniqueness of the emotional component of the psychological health of modern students. Let us characterize some of them in the context of two aspects. The first one reflects the aggravation of the psychological health problem of modern student youth, universally recognized by researchers, and actualizes the importance of psychological support for the development process of the indicated integrative personality traits and the conditions of higher education. The result of the empirical study ${ }^{27}$ proved a non-linear relationship between the level of psychological resource of a modern student's personality and identity status ("achieved", "moratorium", "diffuse"), as well as a direct relationship between his or her ability to restore their own resources and positive feelings experienced in communication.

The fact of slow students 'psychological health development has been established $^{28}$, which actualizes the need for systematic support of this process in higher school conditions, in particular, through the use of thinking tools via metaphors (analogy, comparison, "history methods", etc.), such as - "Imagine your psychological health. What does it resemble? Why do you think so?".

According to the experimental data that the researchers obtained, the second aspect of the problem is highlighted - the weight of the emotional component of the psychological health of modern students is increased, which is due not only to the dual nature of emotional phenomena (after all, emotions cannot be reduced to subjective emotional experiences of individuals). Thus, as a result of an empirical study, it was established: $18 \%$ of students of some higher educational institutions in Lviv have inherently high indicators precisely in the context of the scales "emotional psychological problems". According to Canadian researchers' data, every

\footnotetext{
27 Штепа О.С. Особливості психологічної ресурсності осіб 20-25 років з різним статусом ідентичності // Наука і освіта. - 2013. - № 7. - С. 204-208.

28 Токман А.А., Немченко Н.В. Психологія способу життя: Навч.пос. - Ч. І. - К.: Дп Вид. Дім «Персонал», 2015. - 344 с.
} 
sixth student at Queen's University was diagnosed with "depression"29. There is evidence that every third student of Sumy State A. Makarenko University has a low personal potential, which testifies, in particular, to the inclination to emotional lability.

Our multiyear psychological observations coincide with the conclusions of some foreign researchers regarding the fact that the beginning and end of the academic semester in higher school is the most risky with respect to the negative consequences associated with students' stress.

We share the opinion of those scientists (in particular, of D. Goleman) who from a new angle evaluate the relevance of the basic meaning of the "emotional factor" in a psychologically healthy person, contained in the philosophical heritage of ancient Greek thinkers. So, it is advisable to consider the context of Socrates's statement "Know yourself" not emotional intelligence but the fact of awareness of one's own feelings when they arise. As for Aristotle's research of the meaning of "decent life" in his work "The Nicomachean Ethics", it should be emphasized that it consists precisely in teaching people to manage their emotional lives with the help of intelligence; moreover, according to Aristotle, the point is not in emotionality, but in the appropriateness of emotions and their expression.

So, it is advisable to understand psychological health (in terms of quality) as the ability of a person to possess his or her own emotional sphere, the introduction of the natural nature of behavior, where there is no place for unbalanced mental activity. We are talking about a person's ability to understand, realize and control mental activity already at a young age, in particular due to training the dynamics of mental processes and the possession of the emotional sphere.

\section{CONCLUSIONS}

In modern conditions of increasing information pressure on the personality, aggravation of crisis phenomena in the sociocultural life of a person and the critical condition of the environment, the whole range of problematic issues related to psychological health is significantly actualized at all the stages of ontogenesis (in Greek ontos - being, essence and genesis

\footnotetext{
${ }^{29}$ Lessard F.E. (2016) Enquete sur la sanre psychologique etudiante Montreal: Federation des associations etudiantes du campus de l'universite de Monreal, 129 p.
} 
- origin - the process of a human body individual development throughout life. It is said about a protective-compensatory potential of the personality, when sensory hyper stimulation occurs at all levels of perception of the surrounding world. The aforementioned increases the significance of the value-based relationship, first of all, of a young person to his own health in the psychological sphere, because the imperative of values - part of a person's life - has a direct connection with its openness to the "outside world and inner experience". Therefore, it is important, in particular, in the student years, to acquire tools to enrich the value attitude to psychological health. Given that it is the emotional state "directly" and "now" that is a "snapshot of a person's health", the deepening of scientific ideas about the emotional and personal characteristics of a student's psychological health is becoming extremely acute.

The theoretical analysis of scientific approaches to the knowledge of the emotional and personal characteristics of the students' psychological health allows us to expand our scientific ideas about the psychological laws and mechanisms of personal health in the psychological field. The prospects of scientific research lie in the plane of model development which directs the student's self-regulation process in terms of motivational and emotional levels, as well as the phasing of the deployment of educational and professional activities. By taking into account the emotional and personal component of psychological health, it becomes possible to predict the positive dynamics of individual health in the psychological sphere.

\section{SUMMARY}

The problem of the vitality of a modern young person has been raised, where his or her psychological health is an important marker. Health, as the basic concept of this phenomenon, is quite actively studied in the plane of interdisciplinary scientific knowledge. This is due, first of all, to the scientists' attempt to investigate the essence of the outlined phenomenon, taking into account its multidimensionality, since it is a question of health, both physical, psychological, spiritual, and social. But, despite the significant explanatory value that is inherent in the psychological originality of a certain phenomenon, this aspect is still on the periphery of scientific research. Such angle of understanding the personality's psychological health is becoming extremely acute in the context of 
scientific discussion which is taking place now regarding such "polar trends" that (O. Asmolov, O. Shekhter, O. Chornoryzov) specialization and universalization of cognition are considered.

The study and generalization of the scientific fund on the research problem shows that at present such powerful research concepts as medical, biomedical, biosocial, value and social have developed. Constructiveness, in particular the latter, has already been recognized in the framework of the subject specifics of experimental psychology, developmental psychology, social psychology, health psychology, and educational psychology. The legitimacy of the phenomenology of health in relation to the construct "the individual meaning of life" has been proved, to study the problems of health in terms of understanding the dynamism of a healthy state and interpretation as a person's ability to "optimal practicality, social activity with a maximum life expectancy" (V.Kazacheyev). It has been established that among modern scientists the position dominates, according to which it is advisable to study the personality's psychological health in terms of the reserves of adaptive capabilities of particular profession representatives.

It has been ascertained that basically scientific ideas have been formed about the scientific status of the concepts of " mental" and "psychological health", about the interpretation of psychological health as a dynamic process, about the appropriateness of linking a person's psychological illness to the choice of a passive life strategy, about the legality of determining common criteria for a person's psychological health regardless of his or her age identity.

As a result of the analytical work, a circle of problematic issues requiring scientific understanding has been outlined. At the same time, taking into account the methodologically worthwhile observation by A. Maslow that the trajectory of "movement" in the psychological health of a personality has a line in the direction of "approaching social harmony".

\section{REFERENCES}

1. Асмолов А.Г., Шехтер А.Д., Черноризов А.М. Что такое жизнь с точки зрения психологии: историко-эволюционный подход к психофизической проблеме. Вопросы психологии. 2016. № 2. С. 3-23.

2. Бочавер А., Ступак P. XXIV Европейская конференция по психологии здоровья «Здоровье в контексте». Психологический журнал. - М.: Наука, 2011. Т. 32, вип. 2. С. 116-118. 
3. Вилюнас В.К. Психология эмоциональных явлений - М.: Издво МГУ, 1976. - 143 с.

4. Гаврилюк I. Емпірична експлікація суверенності психологічного простору в показниках соціального контролю особистості // Психологічні перспективи. - Вип. 33. - Луцьк, 2019. - С. 49-65.

5. Гоулман Д. Эмоциональный интеллект: пер.с англ. А.П. Исаевой. - М.: АСТ: Астрель, 2011. - 478 с.

6. Данчева Т. Д. Типология психологического здоровья личности // Наука і освіта, 2012. - № 3. - С. 50-54.

7. Ермолаева М.В. Психология развития : учебное пос. - 3-е издание, стереотипное. - Москва : МПСИ ; Воронеж : МОДЭК, 2006. $376 \mathrm{c}$.

8. Завгородня О.В. Питання збереження психологічного здоров'я: визначення, критерії, умови збереження. 2006. № 3(52). С. 87-96.

9. Карпенко В., Миколайчик М, Войтенко В., Мединська Ю. Сучасний стан психічного здоров'я студентської молоді : емоційна, міжособистісна та рольова сфери // Практична психологія та соціальна робота. - 2012. - № 11. - С. 2-8.

10. Кікінеджі С. Гендерна ідентичність в онтогенезі особистості: монографія. - Тернопіль: Навч.книга-Богдан, 2011. - 400 с.

11. Кириленко Т. Емоційна сфера особистості: вектори вивчення // Вісник Київського нац. ун-ту ім. Т. Шевченка. Психологія. 2018. - № 1 (8). - C. $26-29$.

12. Кремень В.Г. Освіта має визначити розвиток духовності й культури // Креативна педагогіка. - 2011. - № 4. - С. 11-12.

13. Максименко С. Д. Генезис существования личности - К.: Издво ООО «КММ», 2006. -240 c.

14. Маслоу А. Психология бытия. - К.: Ваклер, 1997. - 304 с.

15. Прохоров А.О., Валиуллина М.Е., Габдреева Г.Ш., Гарифуллина М.М., Менделевич В.Д. Психология состояний: Уч. пос. / Под ред. А.О. Прохорова. - М.: Изд-во «Когито-центр»$623 \mathrm{c}$.

16. Психология здоровья / Под ред. Г.С.Никифорова. СПб: Питер, 2003. 607c.

18. Роджерс К. Искусство консультирования в терапии / Пер. с англ. Кондрашова О.И. и др. - Москва: Апрель Пресс: Эксмо, 2002. $976 \mathrm{c}$. 
19. Рубінштейн С.Л. Проблеми загальної психології. - М.: Педагогіка, 1973. - 424 с.

20. Токман А.А., Немченко Н.В. Психологія способу життя: Навч.пос. - Ч. І. - К.: Дп Вид. Дім «Персонал», 2015. - 344 с.

21. Хухлаева О.В. Психология развития: молодость, зрелость, старость. - М.: Изд-ий центр «Академия», 2002. - 208 с.

22. Чебикін О.Я. Становлення емоційної зрілості особистості: монографія / О.Я. Чебикін, І.Г. Павлова. - Одеса: СВД Черкасов, 2009. $-230 \mathrm{c}$.

23. Штепа О.С. Особливості психологічної ресурсності осіб 20-25 років з різним статусом ідентичності // Наука і освіта. - 2013. № 7. - C. 204-208.

24. Шувалов А.В. Гуманитарно-антропологические основы теории психологического здоровья. Вопросы психологии. 2004. № 6. C. $18-33$.

25. Arslan S. Social emotional learning and self-regulation: The mediating role of critical thinking. International Journal of Learning and Change. 2018. 10(2), p. 101-112.

26. Lessard F.E. (2016) Enquete sur la sanre psychologique etudiante Montreal: Federation des associations etudiantes du campus de l'universite de Monreal, $129 \mathrm{p}$.

Information about the author: Kichuk A. V. $\operatorname{Dr}(\mathrm{PhD})$ of Psychological Sciences, Associate Professor, Department of General and Practical Psychology of the Izmail State University of Humanities 


\section{THEMATIZATION OF CULTURAL PRACTICES IN THE CONTEXT OF PSYCHOLOGICAL COMPENSATION}

\section{Kopiyevska O. R.}

\section{INTRODUCTION}

Present-day has actualized the issue of cultural practices transformation, their meaningful functional content which will provide a variety of Ukrainians' needs.

Cultural practices are a powerful compensatory tool. The substantial essence of cultural practices can provide a variety of human needs, including psychological ones.

By cultural practices, we mean "the subject-practical activities of a person/people related to the creation or distribution of cultural products. Cultural practices arise from the scope of meanings of socio-cultural existence, and individual human life, thus are conceived, represented, and implemented within available, personalized axiological horizon"

Thematization of cultural practices in the context of psychological compensation provides the scientific understanding and theoretical justification of functional components which will allow describing in detail the development of the algorithm, methods of effective implementation in practice.

It should be emphasized that the understanding of the psychological and compensatory component of cultural practices is actualized in connection with the global intercultural processes that have actively entered the Ukrainian reality.

In our opinion, it is in the analysis of transformational processes in the cultural practices of Ukraine of the late XX - early XXI century through the prism of global, glocal, and local one should take into account the problem of the discrepancy between the established strategies of cultural creation and the cultural realities of today, which require fundamentally different approaches to the development and implementa-

\footnotetext{
${ }^{1}$ Копієвська О.Р. Трансформаційні процеси в культурних практиках України: глобальний, глокальний контекст та локальні особливості (кінець XX - початок XXI ст.) : дис. ... д-ра культурології : 26.00.06. Київ, 2018. С. 72.
} 
tion of effective socio-cultural transformations to ensure and implement psychological balance. The mentioned issue determines mostly the range of problems that are associated with the interdisciplinary understanding of the research topic that we violate that requires scientific justification, practical prospects, and study.

In addition, in our opinion, recourse to categories of "practices" and updating the study of cultural practices are managed not only by the pragmatic turn, the specificity of which is, in particular, and the refusal of the opposition of private and public in favor of intermediate regimes, their coordination, and the change of paradigm of thinking and the whole complex of turns, which occur in the second half of the XX century which confirms the interdisciplinary nature of the particular concept. Defining the contours of the twists and turns concerning the thematization of cultural practices would contribute to the expansion and diversity of cognitive tools knowledge of the psychological and compensatory reality of human existence.

\section{Theoretical understanding of the psycho-compensatory potential of cultural practices}

For a long time, changes in cultural practices theorists associated with global changes that cover different areas of human life.

Changes taking place in modern Ukraine require to focus on the features of modern cultural practices which unfortunately are not always characterized by positive results and effects on the consciousness of Ukrainians, especially the young people.

That is a reason why the modern scientific community actualizes the need to study a number of related issues, namely: the impact of these processes on mental changes, the identification of society and personality; the development of value priorities in current conditions of development in Ukraine. The issues of the role and importance of cultural practices in the system of formation of the cultural landscape and functioning of the primary network of cultural institutions, which in our opinion are the primary producers of cultural services, are updated.

Consideration of the peculiarities of the processes under study led mostly to the analysis of the spectrum of problems that arise in the process of domestic cultural transformations, the development of effective 
practices to overcome the negative consequences of global transformation for Ukraine, its local areas and territories.

G. Nourishev delineates the geo-cultural space in its local mode as a system of stable cultural realities and events that are formed on a particular territory as a result of the coexistence of overlapping, interaction, the collision of faiths, cultural traditions and norms, values, underlying psychological structures of perception and functioning of the world. ${ }^{2}$

Namely, the local context of the development of modern cultural practices that actualizes the issue of transmission of traditions from generation to generation raises the question of preserving mental characteristics and the corresponding national interest.

In our opinion, the traditional and mental allow compensating psychologically for national among the challenges of the global world.

In this context, there is an urgent need to understand the problem which will solve a significant number of various problems, including the role of cultural practices in the psychological compensation of human desires and needs.

Considering the recompense as a specific compensation for expended effort, as balancing emotional states, we focus on the exceptional importance of social practices, cultural in particular, which are characterized by a powerful communicative and compensatory potential and, accordingly, conceptualized various scientific trends and theories.

Due to the features and subject content of theoretical psychological knowledge and its practical value category of compensation is one of the keys.

Thus, the subject of acute discussions is the understanding of various factors affecting the psychological state of a person, the study of compensatory phenomena and aspects.

It is worth noting that each branch of knowledge is characterized by its own, different from the other way of conceptualization and the inclusion of psychological compensation in the scientific tradition. Such specificity is also associated with optics vision the individual authors of the implementation of the individual research programs and the fact that Paul Ricœur has called "engaged subjectivity involved due to the expected objectivity"3.

\footnotetext{
${ }^{2}$ Нурышев Г.Н. Геокультура : теоретико-методологические основания. URL: http: //www.ibl.ru/konf

${ }^{3}$ Ричард Дж. Так что же такое культурне исследования? // Логос. 2012. № 1. С. 36.
} 
By acquiring an interdisciplinary focus, the practice focuses on dialogue, rejection of absolutization and universalization, demonstrates the ability to "hear the truth of Another." The mentioned fact is especially actual in the context of the cultural practices since any culture within which it is formed is not a self-contained monad. Theorists of the dialogical concept of culture (M. Bakhtin, V. Bibler, M. Buber) proceed from the fact that each culture, despite its uniqueness, is able to live and develop only on the edge of cultures, in dialogue with other cultures, and without such interaction, what is defined as intercultural dialogue, it is doomed to degradation.

The practice is understood not only as a phenomenon of action but also as a phenomenon of culture, knowledge, and cognition; it is investigated in the discourse of strategies of thinking and life, tradition and innovation. Among scientists, there are attempts to distinguish the concepts of practice, activity, and action, since they are identified practically on the basis that they belong to the theory of macro-level. ${ }^{4}$

A slightly different approach is proposed by A. Dyakov, who believes that the structure of the practice includes the categories "action" and "activity", where the latter is understood as a specific practice. In the structure of practice, he distinguishes two main components: internal and external. Internal-contains spiritual and volitional efforts of the person, and the main category of analysis when considering it, he considers the concept of moral action. "External" practice is an instrumental-objective relationship of a person to the world; the equivalent of this concept is the concept of material-objective activity ${ }^{5}$.

These are complex issues and require independent, in-depth research, which, despite the importance, goes beyond the objectives set in the thesis. However, for us, the vital question of background, as V. Volkov and O. Kharkhordin emphasize environment character of the practices. "The simplest understanding of background practice is simply the activity context in which a statement or behavior is interpreted." That is, the background is the context within which the individual acts ${ }^{6}$.

\footnotetext{
${ }^{4}$ Смирнов А.В. Дискурсивные практики как инструмент исследования повседневности // Вестник Орловского государственного университета. Сер. Новые гуманитарные исследования. 2012. № 2 (22). C. 264-267.

5 Дьяков А.А. Философия и практика: было ли прошлое, есть ли настоящее, будет ли будущее? // Наука. Философия. Общество : материалы V Российского философского конгресса. Новосибирск, 2009. T. I. C. 435.

6 Волков В.В., Хархордин О.В. Теория практик. СПб. : Европейского университета в СанктПетербурге, 2008. 298. С. 18.
} 
It should be clarified that the concepts of figure and background are used in Gestalt psychology (M. Wertheimer, K. Koffka), where their relationship plays a semantic and system-forming role. The figure is more important than the background, which is the basis. The idea of the background practices borrows from the works of the late L. Wittgenstein, G. Garfinkel, and develops its concept practices. The opponent of the theory of practices. Volkov and A. Gerhardy and developer of the theory of frames V. Vakhshtein write that in L. Wittgenstein, the context of practical action is comprehended in the categories "background" or "framework"). Accordingly, the practice itself, which is in the foreground, is seen as a"figure in the background" ". The scientist also analyzes the metaphor of the background and figure, where the background is the context, and the figure is any everyday practice. The context, understood as a background, is something "visible, but not seen." The researcher also draws attention to the fact that "the practice act and its context (described through another practical act) change places in the process of their interpretation analysis" 8 .

Without going into the controversy between the authors of the theory of practices and frames, we want to pay attention to the dynamic and inversion nature of the "figure-background", that is, practice and context, and their spatial and temporal ordering. In the deployment space of the "figure-background" disposition, the figure will be the practice, and the background is the context, the background of the implementation by active producers of the algorithm of a particular practice. If the background, as A. Dyakov writes, "denotes the entire palette of the semantic content of life, based on which the research thinking distinguishes this or that activity, this or that practice", thus, the background, context, and framework is culture. $^{9}$

Moreover, all practices at the same time, become "a priori background - that is, socio-cultural", which becomes "a common feature, an attribute of practice as such"

\footnotetext{
7 Вахштайн B.C. «Практика» vs. «фрейм»: альтернативные проекты исследования повседневного мира // Социологическое обозрение. 2008. Т. 7. № 1. С. 65.

${ }^{8}$ Вахштайн В. Социология повседневности и теория фреймов. СПб. : Европейского университета в Санкт-Петербурге, 2011. С. 51.

${ }^{9}$ Дьяков А. Теория практик: Социально-философский потенціал концепции // Известия Саратовского университета. Философия, Психология. 2011. № 1. С. 9-12.

10 Настояща К.В. Атрибуції поняття практики: колізії означення і пошуки верифікацій // Грані : науково-теоретичний альманах. 2018. Т. 21. № 1. С. 57.
} 
Restructuring the subject field of socio-humanitarian knowledge in the context of various rotations and increasing interest in culture eliminates the markers of interdisciplinary spaces. Decisive shifts in scientific discourse at the turn of 1970-1980s have been associated with the dissemination of methods of cultural anthropology, social psychology, linguistics (especially the history of mentalities and popular culture), with the formation of sustained interest in microhistory, the return from analysis impersonalized structures to the study of the individual, specific life situations ${ }^{11}$.

Thus, considering the phenomenon of compensation in psychological knowledge, we have to state that we interpret the latter as a specific protective mechanism, human ability, which is aimed at the independent settlement of their problems, complexes, desires, expectations and the like. In the decision of the specified settlements not aby what role belongs to cultural practices which comprehension demands the personal (individual) approach in the context of socio-cultural identification of human potential.

The global revision of the socio-cultural identification of a person has always led to a change of outlook, in particular, the system of values. It is the human system of values, its transformation that allows a person to rethink the own psychological characteristics.

By understanding the world, a person decides what is essential to life and what is not, what is essential, and what is not vital, what he/she can do without, and what is not. Concerning the culture of the individual, we can say that value is something without which the existence of this person loses its meaning entirely or partially. Any system of values is dynamic and mobile: it is transformed in time with age, change of life circumstances, etc. The personality develops (or accepts readily) system of values which allows being guided in the world, to distinguish important from unimportant, necessary from unnecessary. At the same time, the more durable and conscious system of emotional and value orientations, the more stable personal self-consciousness, the more purposeful human activity.

Value is an integral element of any activity, and therefore of all human life. Even Socrates and Plato turned to the problem of value, in medieval theorizing that moved mainly from the theoretical ("heavenly")

\footnotetext{
${ }^{11}$ Раздина Е.В. Трансформация национального государства в мировой системе институтов власти под влиянием процессов глобализации // Гуманітарний часопис : зб. наук. пр. Харків : XАI, 2010. № 2. C. $121-127$.
} 
world to the real ("earthly"); obviously, the value approach prevailed. However, as a philosophical category "value" entered into scientific circulation in Modern times. Thus, in the works of T. Hobbes, G.V. Leibniz, B. Spinoza values are defined as a manifestation of the human emotional sphere, desires. Feelings are the source of values. G. Lotze expressed the opinion that it is necessary to clearly distinguish the world of phenomena and the world of internal values. Based on the categorical status of value, philosophy of value, or axiology, was formed.

Since the mid-twentieth century, the interpretation of the category values in Western philosophy has occurred. A lively discussion started various directions in understanding the value (value as an idea and as an expression of subjective desire). It should be noted that in Ukraine, only in recent decades began an ongoing study of the problem of values. The mentioned fact was facilitated by the transformation of the old system of values and the search for a new value orientation of social and personal life.

The most valuable for the individual are those objects of the world that correspond to its spiritual, material, social needs, moral principles, attitudes, and ideals. Therefore, an essential feature of culture is that systems of cultural values are formed based on the selection of certain types of behavior. It is believed that this selection is based on both spontaneous and conscious desire for consolidation, which provides the best conditions for the survival of the ethnic group. One of the factors of such consolidation is the union of the value system in the form of certain cultural traditions which are transmitted from generation to generation as significant socio-cultural normative regulators of all spheres of social and individual life of the ethnic group.

Of course, there are still nonconformist values (or marginal), where value is rejected not because it is terrible in itself, but only because it is not recognized in society. Indifferent attitude to the values of A. Esin explains that the person is based on their values, which may not coincide with the officially recognized ones ${ }^{12}$.

It is clear that during the radical transformation that we are now experiencing, there is a change in the fundamental norms of regulation. A radical change in the system of values can lead to destabilization of society, chaos in public relations, General marginalization, loss of ethnic

\footnotetext{
12 Межуев В.М. Ценности современности в контексте модернизации и глобализации // Информационный гуманитарный портал «Знание. понимание. умение». Философия. Политология. 2009. № 1 .
} 
identification. There is a need to identify the spiritual and value foundations on which the future bases. The future of society largely depends on how the value foundation will be formed.

As a rule, when we talk about relations between people and cultures, we emphasize the need for a tolerant attitude to each other. There are many different cultures in the world, and almost all of them interact with each other. Due to culture, the intercultural dialogue emerges between representatives of different ethnic, national, and religious communities, which is based on the values characteristic of this culture, one of which is tolerance. Scientists tend to research the essence of the problem of tolerance more often but use different content in this concept. Linguists see tolerance as toleration, political scientists explain it as the ability of the individual and the human community to listen and respect others.

According to psychologists, tolerance is the ability of a person to understand another person, to feel and be aware of the person's feelings and emotions ${ }^{13}$.

Tolerance means understanding; it recognizes the right of other cultures to exist. Tolerant civil culture assumes, firstly, that the individual with the own system of values is not suppressed, and secondly, tolerance of the culture of society is manifested in the fact that other civil cultures also retain the right to exist. Exploring the phenomenon of tolerance, American psychologist Gordon Allport identified three types of tolerance: tolerance as a system of attitudes related to ethnic and racial differences, comfortable tolerance, and tolerance as a trait. From ethnic attitudes, tolerant of the individual is configured according to G. Allport, believes that "all people are equal: group identity in most cases does not matter. Tolerance as a trait means a respectful attitude of its bearer to other people. This respect is manifested in different lifestyles and life strategies. Some people carry a charge of love and goodwill, appreciate group differences from an aesthetic point of view, and find them attractive. The other ones associated the attitude to different groups with the concept of international friendship ${ }^{14}$.

Different interpretations of the concept of tolerance are united by the idea of a positive attitude of tolerance to the preservation, development, respect for cultural identity. In this context, tolerance is an essential

\footnotetext{
13 Почебут Л.Г. Взаимопонимание культур: методология и методы этнической и кросс-культурной психологии. Психология межэтнической толерантности. СПб. : Изд-во С.-Петерб. ун-та, 2005. С. 73.

${ }^{14}$ Кондратьев М.Ю., Ильи В.А. Азбука социального психолога-практика. М. : ПЕР СЭ, 2007. С. 34.
} 
component in determining the priorities of national interests; preservation and development of the cultural potential of the nation; peacekeeping orientation of international cultural cooperation. A tolerant attitude to other cultures and nationalities is actualized in the process of integration of national culture into the European civilizational space. Intercultural dialogue and tolerance are defined in their psychological and practical interaction. Intercultural interaction contributes to the enrichment of spiritual values, the growth of interest in other cultural traditions and religions. The realities of today show that new information systems expand opportunities for intercultural communication as well as help representatives of different ethnic groups organically join the world cultural space. The mentioned aspect creates a tolerant attitude towards other peoples and, accordingly, reduces feelings of rejection, discrimination, exclusion, and intolerance. It is only the reduction of these feelings that leads to psychological stability and balance among the participants of cultural practices.

The nature of value is perfect. According to Y. Bilodid (however, all philosophers agree with this, and no one denies this idea), the value in its origin is generated by the formation of the ideal world of man and contributes to its self-assertion in society. One of the functions of value is to connect the past and the future in the modern human being. In our opinion, this is a good idea, although controversial. Thus, from the midtwentieth century, humanity has mapped new values associated with success in science, technology, and industry. There have been significant changes in the level and quality of life. All that was encouraging opened outlook created a belief in stability, has formed a value-based imperative. At the same time, humanity realized that technology is not only able to facilitate life, to give material well-being, but also to destroy nature. The technique is the field of realization of the creative imagination of a person, but it also generates psychological dependence of a person ${ }^{15}$.

There is no doubt that values are the basis of worldview. At the same time, it should be remembered that the world of values of a culture can never be entirely adequately transformed into the world of another culture. This transformation should take into account the psychological characteristics of the person.

\footnotetext{
15 Бессонова О.Э. Раздаточная экономика России : Эволюция через трансформации. М. : Российская политическая энциклопедия (РОССПЭН), 2006. С. 18-20.
} 


\section{The psychological phenomenon of global transformations in cultural practices}

Transformations caused by globalization, significantly change the moral, ethical, and psychological state of the human, and therefore the Ukrainian society as a whole. Therefore, there are destructive changes in social, individual consciousness. In particular, there is a growing concern of the world community concerning violence, drug addiction, ethnic conflicts, etc. World cultural picture, identifying destructive changes, requires the search for optimization strategies and adequate perception of contemporary cultural reality, which in turn predetermines the necessity of forming a new, global ethic, which on the background of intercultural tensions and "civilizational clashes" is gaining speed.

American Russian Americans theorist N. Epstein, who studied the transformational processes of the late twentieth century, notes the "lag of man from humanity" and explains this by the growing disproportion between the development of human individuality, limited by biological age, and the socio-technological development of mankind, for which the time limit is not set (at least no one knows). With each generation, a person is forced to learn a more and more voluminous load of knowledge and impressions that were accumulated by previous centuries and that it is not able to assimilate. Hence, as the theorist notes, the problem of alienation, outlined in the nineteenth century, and the problem of loss of reality - in the twentieth century.

Scientists associate the specifics of communication reflection with the processes of globalization, which are characterized by absolute destruction of isolation, under the influence of a robust public information field and increasing trends of virtualization of social reality. Thus, according to scientist E. Savrutska, the openness of the communication space of modern civilization makes a person as if involved in events, the real subject of which is not connected with the one. That is why in the real space of a person's own life, there is a combination, and often the replacement of value systems, spiritual and moral guidelines of the culture ${ }^{16}$. Modern trends that dominate in society convince the scientific world that "human becomes a problem for him/herself." The tension of the world, which is

\footnotetext{
16 Савруцкая Е.П. Коммуникационный аспект инновационных трансформаций в конструировании социальной реальности // Культурологический журнал : Электронное периодическое рецензируемое науч. изд. 2012. № 3 (9).
} 
directly associated with one of the main themes for modern science, namely the transformation processes in culture, is due to the problem of preserving the cultural integrity of human, connection with the world, the own essence.

Under the influence of cultural transformations, there is a change in relations between people, and new images of the real world are formed, which significantly affect the system of cultural values. In the communication processes of a real person as an object of interest and attention on the part of the "other" is replaced by consumer goods, and the Internet as a kind of computer interlocutor gradually takes a dominant place in terms of the person's world.

Modern information and computer technologies allow a person to penetrate the most secret corners of the intimate life of a personality, thereby destroying one's world by changing the worldview. There is a particular communicative situation in which the processes occurring in the communicative space are provided with a large number of entirely new means of accumulation, storage, and transmission of information.

On the one hand, there is a devaluation of cultural, spiritual, moral attitudes, rules, principles, norms, behaviors, on the other - universal values are formed, which, even being blocked in a stable environment, find auxiliary, indirect forms for their development. Their further implementation at a higher taxonomic level becomes a global problem. Thus, globalization contributes to the crystallization of universal value categories that form the architectonics of the new world order. The problem of a psychological dependence on global changes is actualized.

Figuring out the essence of the phenomenon of psychological compensation, scientists, and first of all, representatives of psychoanalysis, emphasize a deep connection over-consciousness, consciousness, and mentality.

By having defined mentality as a particular way of thinking, a warehouse of the human soul, it is necessary to emphasize that mentality is characterized by certain specifics in perceived and interpretation of the world by the individual.

In terms of the analyzing the content of the mentality, the scientists emphasize that the one is represented as a well-established historical experience, forms, and ways of expressing the intellectual and emotional 
reactions, stereotypes of behavior, archetypes of culture and sociopsychological the willingness of social actors" ${ }^{\text {"17 }}$.

Quite an extensive use of the term mentality in everyday life and the presence of its various interpretations in the scientific community indicates a growing interest of researchers to the mentioned phenomenon (L. Batkin, M. Bakhtin, L. Vygotsky, A. Gurevich, G. Duby, S. Krymsky, A. Kulchitsky, S. Rubinstein, A. Strážné, A. Furman, V. Shkuratov, N. Shlemkevych, etc.). It should be noted that in the national tradition of the study of national mentality, although without the use of the concept, associated with the works of N. Kostomarov "Books of the Genesis of the Ukrainian People" and" Two Russian nationalities"18. Later, on the particular problem O. Kulchytsky, Y. Onatsky, B. Cymbalisty, D. Chizhevsky, M. Shlemkevych worked. The researches of the mentioned scientist were represented to the public in 1992 when a collection "Ukrainian soul" was published where the original research concerning the outlook of our people was presented ${ }^{19}$.

A set of different symbols and images reflect the idea of a specific society about the world and, in turn, determine the motives of behavior and actions of people, which are fixed in the minds of people in the process of communication and determine their mentality. It is formed under the influence of natural conditions and social realities, reflects and reveals the picture of the world, which consolidates the unity of the cultural tradition of a particular cultural community. This kind of perception of the world is born in the depths of over-consciousness that claims Freud in the studies of the human soul and the structure of the psyche.

The doctrine of the personal unconscious, substantially supplemented the Swiss psychologist, cultural commentator, and the founder of analytical psychology K. Jung, focusing on the archetypes and the collective overconsciousness, attempting to penetrate the unconscious is more profound than his teacher. Archetype as a collective unconscious is a kind of outcome of the life of the genus (people, ethnos, nation), which is inherited from ancestors and appears as the basis on which the individual psyche grows. Archetypal images, according to Jung, always accompany a person.

\footnotetext{
${ }^{17}$ Кримський С., Заболоцький В. Ментальність // Філософський енциклопедичний словник / ред. кол. : B.І. Шинкарук Є.К. Бистрицький, М.О. Булатов та ін.; Інститут філософії ім. Г.С. Сковороди НАНУ. К. : Абрис, 2002. С. 369-370.

${ }^{18}$ Костомаров М. Книги буття українського народу // Українознавство : хрестоматія. К. : Либідь, 1993. C. 238.

${ }^{19}$ Українська душа / заг. ред. В. Храмова. К. : Фенікс, 1992. С. 56.
} 
They are the sources of mythology, religion, art, culture and through them influence the organization of the life of the people. Thus, Jung adds another dimension to the understanding of the unconscious and thus begins a new perspective of understanding the phenomenon of mentality ${ }^{20}$.

Mentality and culture are close structurally, interrelated, but qualitatively different phenomena, and therefore the categories which they mean contrast. The more fundamental nature of culture as compared to mentality is that different cultures are not able to form a single mentality, although they interact, often contradictory. Based on mentality, a particular type of cultural practices is formed, and this process is quite long, responsible, and ambiguous. However, in both cases, national culture is formed, the features of which various cultural practices are reflected. Thus, by defining mentality as an essential component of socio-psychological self-organization of representatives of a particular cultural practice, scientists note that it is characterized by the unity of attitudes, experiences, thoughts, feelings, and manifests itself in the identity of worldview ${ }^{21}$.

In the three-component structure of mentality, emotional coloring is essential, it appears in the form of a complex range of feelings, moods, temperament features, emotional and volitional aspirations and forms of expression determined by them in images, sounds, colors, the totality of which is not only in everyday life but also in traditions and cultural practices. That is the reason why, determining the cultural and historical conditionality of mentality, scientists note the variability of public attitudes, fluctuations in public opinion, and emotional impulses. "Mobility" of cultural and historical factors, as noted by A. Hutka, can cause significant modifications, deformation of mental attitudes of a particular ethnic group ${ }^{22}$.

The multifaceted phenomenon of cultural practices is characterized by a common opinion about their primary purpose, which is to form a common understanding of the essence of human life. Cultural practices create a single cultural space, a meaningful field of human existence, its cultural socialization. The interaction of cultural practices and a person

\footnotetext{
${ }^{20}$ Кримський С., Заболоцький В. Ментальність // Філософський енциклопедичний словник / ред. кол. : В. І. Шинкарук, С.К. Бистрицький, М.О. Булатов та ін.; Інститут філософії ім. Г.С. Сковороди НАНУ. К. : Абрис, 2002. С. 550.

21 Фурман А.В. Психокультура української ментальності: наук.вид. Тернопіль : Економічна думка, 2002. C. 48.

${ }^{22}$ Хутка О.С. Поняття «національна ментальність» та їі роль в ціннісній системі суспільства // Науковий вісник Академії муніципального управління : зб. наук. пр. Сер. Управління. 2009. Вип. 4 (10).
} 
forms the basis of co-existence, self-determination by the person of their life orientations that is based on the direct interiorization of cultural values, acquiring the character of measuring individual and social life. The process of interaction between cultural practices and human in the modern world, with its various threats and challenges, actualizes the problems of freedom.

The problem of freedom is a rather complex categorical concept. Personal freedom is the absence of various forms of exploitation and oppression, discrimination and persecution, the possibility of committing acts by the will of the person within limits provided for by democratic legislation. It is worth noting that the concept of freedom in our time is often identified with the freedom of choice. The choice seems to be the highest criterion of freedom: there is a choice - there are freedom and development; there is no choice - there is neither one nor the other. Of course, the idea of choice is not the last attribute of freedom.

It is necessary to note that in the second half of the nineteenth century and early twentieth century, people appreciated the freedom through the prism of the negation, rebellion, nihilism. In the early twenty-first century, freedom is understood as a creative, cultural value, dialogue.

Taking into account the deep determination of human behavior by social and historical being, "freedom of choice" becomes a "recognized necessity" for a person (O. Ukhtomsky). No problem goes so far into metaphysical heights and has, at the same time, the most significant practical significance as the problem of freedom.

Human freedom is the will, rationalized, ethical and gnoseological, or involved in the structure of practical and theoretical understanding and have their intentional center. In determining the importance of culture, it is essential to emphasize its levers, namely, a positive impact on human development, the formation of the personality. Defining culture as a particular system of semantic complexes necessary for the person-values which are capable of acting as regulative principles of group behavior, we will designate its value for the development of the individual. Culture enriches its spiritual world, lays the foundations for the formation of a sense of freedom by having an unconditional influence on the content of human life. Culture in all its diversity as one of the spheres of human existence has its inherent levers for human development. Individual human freedom is an integral part of civil freedom, which acquires a new meaning and form in current socio-economic conditions. 
In this context, the question of the role and importance of freedom of choice of cultural practices for the own psychological satisfaction is actualized.

One of the modern cultural trends is the formation of the cultural landscape. O. Lavrenova, who theorizes on the problems of interaction between culture and space, understanding not only the reflection of culture and the creation of images as a result but preferably on the features of the psychological perception of the components of the cultural landscape ${ }^{23}$.

In this context, modern scientific research defines the cultural landscape not only as a geographical environment, nature, or historical memory, but also reflects its practical life of the modern human. Taking the mentioned issue into account, O. Nikitina's research presents the cultural landscape as an existential state of a person, deserves attention ${ }^{24}$.

We pay no less attention to the role of cultural institutions as the main subjects of creation and implementation of cultural practices. Cultural institutions possess all potential opportunities for psychological compensation.

The compensatory function of cultural institutions provides for the creation of necessary conditions for the rest of people from life problems and getting them psychological and emotional discharge.

It is psychologically reasonable to assume that the cultural practices of the modern library contribute to the creation of "zones of personal stability", where the visitor feels more relaxed, confident, and protected than elsewhere. Librarians are consciously working to improve the library environment, from service to design to the surrounding landscape.

A person can receive psychological compensation both from the performance of religious rites as well as cultural, creative practices (reading books, visiting theaters, museums, clubs, concert halls, etc.), tourism or communication with nature, collecting, etc.

Parks are an integral part of the system of psychological compensation of a person. They are organically connected with the general processes of the social and cultural life of modern society. The increasing role, importance, popularity of parks in modern life is connected to the

\footnotetext{
23 Лавренова О.А. Семантика культурного ландшафта : автореф. дис. ... д-ра филос. наук : $24.00 .01 /$ ГОУ ВПО Российский государственный гуманитарный университет. URL: http://dissertation1.narod.ru

24 Никитина А.В. Специфика философско-культурологической репрезентации культурного ландшафта: автореф. дис. ... канд. филос. наук : 24.00.01 / Казанский государственный университет культуры и искусств. Казань, 2013. С. 5.
} 
processes of urbanization of life, the intellectualization of labor, increasing psychological stress on the production, etc. Parks of culture and recreation are characterized by their multifunctionality and diversity of the offered and, accordingly, consumed cultural services, which are designed to meet the demand of all socio-age groups of the population in various types of cultural leisure ${ }^{25}$.

It should be noted that cultural institutions as centers of psychological compensation are not the object of scientific research among scientists of psychological knowledge. However, the role and importance of cultural institutions in the psychological and compensatory recovery of the human are undeniable. The problem of recreation has not yet become one of the priorities in the functioning of Ukrainian cities, although sociologists and psychologists note that, together with the spheres of work and life of the population, recreation has a significant impact on the formation of a unique cultural environment and on improving the quality of human life.

The question of changing educational priorities in training specialists who are able to take into account the trends mentioned above is updated. Professional competence of the modern manager of culture should take into account several related to the own professional activities of knowledge and skills, among which a special place belongs to the knowledge and practice of psychology. Modern training of highly qualified specialists should be based on such an educational program that would take into account the subject area as much as possible. Moreover, it is not only innovation as a static result of cultural practice but also a process of transformation of innovations into socio-cultural, psychological norms, and behavioral models.

\section{CONCLUSIONS}

Having studied and comprehended the thematization of cultural practices in the context of psychological compensation, we have come to the following conclusions:

- Cultural practices are a powerful compensatory tool. The substantial essence of cultural practices allows providing various needs of the person, including psychological ones. The changes taking place in modern Ukraine require us to focus on the features of modern cultural practices, which

\footnotetext{
${ }^{25}$ Копієвська О.Р. Паркова індустрія : підручник. К. : НАКККіМ, 2015. С. 5-6.
} 
unfortunately are not always characterized by positive results and impacts on the consciousness of Ukrainians, especially young people.

- Thematization of the psychologically compensatory phenomenon of cultural practices, their transformations corresponds to the actual problems of the modern development of science and is based on the importance of empirical and theoretical understanding of the scientific, practical potential for the sphere of culture to determine the pressing problems of our time and ways to solve them;

- Issues of the role and importance of cultural practices, their psychological and compensatory potential (resource) for both the individual and society as a whole become particularly relevant. The exclusive role of the research object is outlined in the processes of preservation and formation of mental characteristics of Ukrainians, ensuring freedom of choice, value orientations, and tolerant attitude to each other. Determined by the particular importance of psychological compensation, its functional content in the system of formation of the cultural landscape and the activities of the core network of cultural institutions, in the formation of professional competences of the modern cultural manager, whose educational outcomes should be knowledge and skills in practical psychology.

- There is an urgent need to understand the methodological developments, recommendations for the introduction of psychological compensation in cultural practices, which will solve a significant number of various problems faced by different social and age categories of the population.

\section{SUMMARY}

The role of cultural practices in the context of psychological compensation of the person is investigated and theoretically comprehended in the section. Theoretical bases of cultural practices understanding are analyzed, their contents and essence in the system of providing psychological features as the person, as well as society as a whole, are determined. Meaningfully exclusive psychological and compensatory value of transformation of cultural practices for preservation and formation of mental features of Ukrainians, ensuring freedom of choice, value orientations, and tolerant attitude to each other. The importance of psychological compensation, functional content in the system of cultural 
landscape formation, and activity of the primary network of cultural institutions is actualized. The priority of transformation of professional competence psychological direction for a contemporary cultural manager is underlined.

\section{REFERENCES}

1. Bessonova, O.E. (2006). Handout economy of Russia: Evolution through transformation. Moscow : Rossiyskaya politicheskaya entsiklopediya (ROSSPEN) [in Russian].

2. Vakhstain, V.S. (2008). Practice vs. "Frame": alternative research projects of the everyday world. Sotsiologicheskoe obozrenie, 7, 1, 65-95 [in Russian].

3. Vakhstain, V. (2011). Sociology of everyday life and the theory of frames. St. Petersburg : Yevropeyskiy universitet v Sankt-Peterburge [in Russian].

4. Volkov, V.V., Kharkhordin, O. V. (2008). Practice theory. St. Petersburg : Evropeyskiy universitet v Sankt-Peterburge [in Russian].

5. Dyakov, A.A. (2009). Philosophy and practice: was there a past, is there a present, will there be a future? Nauka. Filosofiya. Obshchestvo : materialy $\mathrm{V}$ Rossiyskogo filosofskogo kongressa. Novosibirsk, I [in Russian].

6. Dyakov, A. (2011). Theory of practice: Socio-philosophical potential of the concept. Izvestiya Saratovskogo universiteta. Filosofiya, Psikhologiya.1, 9-12 [in Russian].

7. Kondratyev, M.Yu., Ilyi, V.A. (2007). Alphabet of a social psychologist-practitioner. Moscow : PER SE [in Russian].

8. Kopiyevska, O.R. (2015). The park industry: a textbook. Kyiv : NAKKKiM [in Ukrainian].

9. Kopiyevska, O.R. (2018). Transformational Processes in the Cultural Practices of Ukraine: Global, Glocal Context and the Local Particularities (the end of XX - the beginning of XXI centuries). Doctor's thesis. Kyiv: NAKKKiM [in Ukrainian].

10. Kostomarov, M. (1993). Books of being of the Ukrainian people. Ukrayinoznavstvo : khrestomatiya. Kyiv : Lybid [in Ukrainian].

11. Krymskiy, S., Zabolotskiy, V. (2002). Mentality. Filosofskiy entsyklopedychniy slovnyk. Kyiv : Abrys [in Ukrainian]. 
12. Lavrenova, O.A. (2010). Semantics of the cultural landscape : Extended abstract of doctor's thesis. Retrieved from : http: // dissertation 1. narod.ru. [in Russian].

13. Mezhuev, V.M. (2009). The values of modernity in the context of modernization and globalization. Informatsionniy gumanitarniy portal Znanie. Ponimanie. Umenie : Filosofiya. Politologiya. Retrieved from : http://www.zpu-journal.ru/e-zpu/2009/1/Mezhuev/ [in Russian].

14. Nastoyashcha, K.V. (2018). Attributions of the concept of practice: conflicts of definition and the search for verifications. Grani: naukovo-teoretychniy almanakh, 21, 1, 56-62 [in Ukrainian].

15. Nikitina, A.V. (2013). Specificity of the philosophical and cultural representation of the cultural landscape. Extended abstract of candidate's thesis. Kazan [in Russian].

16. Nuryshev, G.N. Geoculture: theoretical and methodological foundations. Retrieved from : http: //www.ibl.ru/konf [in Russian].

17. Pochebut L.G. (2005). Mutual understanding of cultures: methodology and methods of ethnic and cross-cultural psychology. Psychology of Interethnic Tolerance. St. Petersburg : Publishing House of St. Petersburg. University [in Russian].

18. Razdina, E.V. (2010). Century Transformation of the national state in the world system of institutions of power under the influence of globalization. Humanitarnyy chasopys : zb. nauk. pr. Kharkiv: KhAI, 2, 121-127 [in Russian].

19. Richard, J. (2012). So what is cultural research? Logos, 1, 80-135 [in Russian].

20. Savrutskaya, E.P. (2012). Communication aspect of innovative transformations in the construction of social reality. Kulturologicheskiy zhurnal : Elektronnoye periodicheskoye retsenziruyemoye nauch. izd. 3(9). Retrieved from: http://www.cr-journal.ru/rus [in Russian].

21. Smirnov, A.V. (2012). Discursive practices as a tool for the study of everyday life. Vestnik Orlovskogo gosudarstvennogo universiteta. Ser. Novye gumanitarnye issledovaniya,.2 (22), 264-267 [in Russian].

22. Ukrainian soul (1992). Ed. Khramov, V. Kyiv : Feniks [in Ukrainian].

23. Furman, A.V. (2002). Psychoculture of Ukrainian mentality: scientific publication. Ternopil : Ekonomichna dumka [in Ukrainian]. 
24. Khutka, O.E. (2009). The concept of "national mentality" and its role in the value system of society. Naukovyy visnyk Akademiyi munitsypalnoho upravlinnya : zb. nauk. pr. Ser. Upravlinnya, 4(10). Retrieved from : http://www.nbuv.gov.ua [in Ukrainian].

25. Epstein, M.N. (2005). Postmodern in Russian literature: textbook for universities. Moscow : Vysshaya shkola [in Russian].

\section{Information about the author:}

Kopiyevska O. R.

Doctor of Cultural Studies, Professor, Head of the Department of Art Management and Event Technologies of the National Academy of Culture and Arts Management 9, Lavrska str., Kyiv, Ukraine 


\section{BASIC STRUCTURE OF A GENDER-SPECIFIC TRAINING COURSE FOR WORKING WITH YOUNG PEOPLE (STUDENTS)}

\section{Kostina T. O.}

\section{INTRODUCTION}

Modern Ukrainian society is in a difficult social, economic, and political situation. The considerable number of changes in the sociopolitical system requires the person to understand the changes that our country must undergo.

The development of the state, as well as the development of the individual, is always accompanied by changes. This principle is reflected in the law of the negation of negation, which indicates the direction and forms of development. This law emphasizes the unity of the sustainable and the variable, that the new is born on the basis of the "old" that was. The main task for both the individual and society as a whole is to understand the possible ways of development and to identify those that should contribute to the highest efficiency of the organism (in the broad sense of the word).

It should be remembered that development is often a painful process that, due to the existing pain (physical or psychological), can block a person's desire for vital change. Such changes for Ukrainian society are gender issues, which are primarily related to the issue of gender inequality and manifestations of gender discrimination. Unfortunately, there are still people in Ukraine (including statesmen) who are not aware of the importance of this issue and the benefit that Ukrainian society will gain from implementing a gender approach in various spheres of public life.

Working with young people (students) is one way to tackle gender inequality. The introduction of training and educational courses on gender equality will allow young people to understand and feel the positive developments that reduce the level of discriminatory behavior. The development of a modern young man must take into account the changes that are taking place at the global level. In particular, examples from 
Western countries have shown the effectiveness of the gender approach (Sweden, Canada, USA).

The task of modern society is to help young people in their development. Such assistance is of particular importance in the context of educational institutions, since it is in them that a large part of life is spent by every young person. The introduction of gender-based courses for students (as a way of combating gender inequality and manifestations of gender-based discrimination) should help students understand the importance of this issue. But it will allow to realize that human development, its personal growth is not possible without rethinking norms and patterns established in the environment. This is especially true of gender stereotypes, which very often interfere with the development of a person and the achievement of goals that are relevant to her/him.

The relevance of the issue of psychological support for the development of personality for pedagogical and psychological science has made our scientific choice today. The results of the scientific search are presented in the form of the basic structure of a gender-specific training course for working with young people.

\section{General structure of the training course on gender issues}

The development and implementation of training programs to prevent gender inequality and gender discrimination should be based on methodological principles for the creation of training courses and should include a methodological background. The development of any training includes a content component that is related to the topics that the course is dedicated to; and a methodical component based on generally accepted principles for the development of training courses. In this subsection, we will focus on the methodological aspects of training, which determine the stage of training work.

The development of training courses has been addressed by such scholars as: I. Vachkov', V. Klimchuk ${ }^{2}$, V. Levi ${ }^{3,}{ }^{4}$, D. Ramendyk ${ }^{5}$, K. Fopel ${ }^{6}$ and others. The writings of these authors provide exercises for

\footnotetext{
${ }^{1}$ Вачков И. Основы технологии группового тренинга. М.: Издательство «Ось-89», 1999. 256 с.

${ }^{2}$ Климчук В.А. Тренинг внутренней мотивации. СПб.: Речь, 2005. 76 с.

3 Леви В.Л. Искусство быть другим. Л.: Глобус, 2000. 254 с.

4 Леви В.Л. Искусство быть собой. Л.: Глобус, 2000. 254 с.

${ }^{5}$ Рамендик Д. М. Тренинг личностного роста. Изд.: Форум, 2007. 82 с.

${ }^{6}$ Фопель К. Психологические группы: Рабочие материалы для ведущего: Практическое пособие. К. : Пер. с нем. 2-е изд., стер. М.: Генезис, 2000. 256 с.
} 
group training. In addition, the specificity of the application of the exercises and their expediency (effectiveness) in accordance with the stages of deployment of group dynamics are explained. In addition, the development of a training course should be based on the age characteristics of the participants who will participate in this interaction ${ }^{7,8}$.

The main points to be addressed in the context of dealing with gender issues are the following:

- expanding the reflection of the individual about himself and social expectations of what the personality should be;

- acquiring information on gender, gender (inequality), gender discrimination;

- highlighting the gender component in the system of social stereotypes both at the level of society and at the level of personality;

- formation of the desire to make changes in one's life (going beyond gender stereotypes).

It should be noted that working with stereotypes should involve a process of awareness that is, first and foremost, ensured by the unfolding of the individual's reflection on himself and the established social norms that the individual is confronted with. In order to develop a person's awareness of themselves and existing stereotypes, it is appropriate to include components in the program that will address different areas of the participants' psyche.

Awareness of oneself (including gender-based stereotypes) will be effective when it occurs at three levels: cognitive (information block), emotional-motivational (experience, attitude towards it) and includes a volitional component (my actions aimed at change) situation). Therefore, the training should use exercises that cover all the specified areas of the human psyche.

When it comes to the substantive component of this type of training, it should include a theoretical component: the basics of gender theory, the peculiarities of gender stereotyping, examples of cases (including advocacy campaigns) that demonstrate an individual's ability to be beyond gender-based expectations.

The training program on gender equality in general should include the following structural elements (blocks):

\footnotetext{
${ }^{7}$ Абрамова Г.С. Возрастная психология. Екатеринбург: Деловая книга, 1999. 621 с.

${ }^{8}$ Божович Л.И. Проблемы формирования личности: Избр. психол. тр. / Под ред. Д.И. Фельдштейна; Рос. акад. образования, Моск. психол.-соц. ин-т. 3-е изд. М.: МПСИ. 2001. 349 с.
} 
1 block (1 lesson) - dating;

Unit 2 (2-9 sessions) - acquaintance with basic concepts of gender theory, definition of basic gender stereotypes, reflection of participants' experience, which included gender-based discrimination; understanding the possibility of changing stereotypes and choosing to go beyond them; building a future plan for combating gender-based discrimination and establishing gender equality;

3 block (10-th session) - completion of training work.

The first session lays the groundwork for further training group work. The atmosphere created at this stage greatly influences the dynamics of further group processes. The peculiarity of this type of training is the need for a friendly atmosphere, since only under such conditions is it possible to reveal one's personality, including in the issue of gender-based discrimination. The first block is aimed at creating a friendly relationship between the participants and the trainer, the formation of a favorable psychological climate, a sense of security of the individual in the group.

The lessons of the second block form the central part of the program. For the effective realization of the set tasks, the participants are offered exercises, the performance of which determines the process of unfolding reflection on gender stereotypes and manifestations of gender inequality in society.

Reflection is carried out through the analysis of personality characteristics; social expectations about the gender distribution of roles (gender stereotypes) ${ }^{9}$, that influence a person's subsequent assessment of her/his "femininity", "masculinity"; looking at the social roles of women and men from a different perspective (analyzing how the existing distribution determines and then analyzing how it can be changed $)^{10}$.

Group dynamics allow the participant to share their own experience and hear the experience of others. This form of work covers not only the cognitive level (information) but also the emotional-motivational level ${ }^{11,12}$.

The training format allows a person to really "relive" the knowledge provided during the training. Because information delivery is always accompanied by exercises that allow you to update a person's past

\footnotetext{
${ }^{9}$ Говорун Т.В., Кікінежді О.М. Стать та сексуальність: психологічний ракурс. Тернопіль: Навчальна книга - Богдан, 1999. 343 с.

${ }^{10}$ Бем С. Линзы гендера: Трансформация взглядов на проблему неравенства полов / [пер. с англ.]. М.: «Российская политическая энциклопедия» (РОССПЭН), 2004. 336 с.

${ }_{11}^{11}$ Перлз Ф. Практика гештальттерапии. М.: Институт Общегуманитарных Исследований, 2005. 480 с.

12 Ялом И. Групповая психотерапия. Теория и практика. М.: Апрель Пресс, Изд-во ЭКСМО-Пресс, 2001. 576 c.
} 
experience, "relive" the experience of other participants and gain emotional experience of interacting in the group. Due to this form of work, there is a process of conglomeration of the individual's partial knowledge about gender in a coherent system of the concept of "gender (in) equality". Exercising the program should contribute to the formation and realization of the life plan of the person beyond the established gender patterns.

The third block of the correction program is aimed at creating favorable conditions for the exit of the individual from the training. The total duration of the training program may be 10 weeks.

The program is aimed at participants aged 18 and over. This age group already has the necessary resources for training in this format. In particular, developed reflection, the quest for self-knowledge, as well as the desire to exercise oneself in this world (search for oneself, partner, friends, etc. $)^{13,14}$. It is during this age period that man is not only able to "go against society" (which is typical for adolescents), but to build his own path. Due to the psychological peculiarities of this age category, the introduction of such training courses will help to increase the level of selfawareness, existing social stereotypes (including gender), which will help to develop a person who is able to strive to establish gender equality and reduce the level of gender discrimination ${ }^{15}$.

It should be noted that the proposed training structure ( 3 blocks) is of a general nature and can be adjusted in accordance with the time (limitations of the training course related to the educational process), quantitative (number of participants) and qualitative indicators (group composition), with which the psychologist/trainer will work.

\section{The content of the training course "Gender (in) equality: I can do more!"}

\section{Lesson 1.}

The purpose of the first lesson is to: formulate the rules of the training group, get acquainted with the participants, create a friendly atmosphere.

At the beginning of the first session, the trainer determines the basic rules of the training work that must be observed by each member of the

\footnotetext{
${ }_{13}^{13}$ Малкина-Пых И.Г. Справочник практического психолога. М.: Изд-во Эксмо, 2007. 784 с.

${ }_{11}^{14}$ Райс Ф., Долджин К. Психология подросткового и юношеского возраста. СПб.: Питер, 2012. 816 с.

15 Як навчати школярів долати гендерні стереотипи: конспекти занять / навч.-метод. посібник для загальноосвітніх навчальних закладів. Т. Говорун, О. Кікінежді та ін., за заг.ред. професора Т. Говорун. К.: ТОВ «Дорадо-Друк», 2006. 804 с.
} 
group. Participants are given the opportunity to complete the list of rules. The basic rules to be followed during the training are:

- Privacy (information remains within the group and cannot be released);

- Activity (participants should "get involved" in the group work, participate in exercises and discussion);

- The principle of "here and now" (participants should be present not only physically but also psychologically);

- To say "I", not "we" or "all" (raises responsibility for one's words, actions, because I speak for myself, not for others);

- Stop rule applies - a participant has the right to refuse to discuss a particular issue or to complete a task;

- Prohibition of criticism (we analyze the results but do not criticize the individual);

- "Better in the circle than home!" (all experiences, thoughts that involve group members are better spoken in the group, shared with other members than carrying this "luggage" home. This rule helps to create and maintain open communication in the group).

Sometimes group members may also suggest additional rules. For example, getting started, disconnecting mobile phones, etc. is timely.

Prior to the exercise of the first session, the trainer hands out badges to participants, on which they write down their name. Now each team member and coach can speak to each other by name.

Exercise "Questionnaire": The purpose of this exercise is to give participants an opportunity to get to know each other better. Identify similar events among group members. Participants are provided with a questionnaire describing cases of gender inequality and gender discrimination.

After the participants have filled in the questionnaires, the trainer reads the answers. If a certain point has taken place in an individual's life, he / she will raise their hands. In this way, others can see that similar situations were in the lives of other participants. So, participants understand that they have a lot in common. And there is still a lot of gender inequality and discriminatory manifestations in Ukrainian society.

Participants are then encouraged to team up with two participants with whom they have a similar response and discuss past experiences together. 
Exercise "Hand": The purpose of this exercise is to establish an atmosphere of trust in the group; determining the presence of stereotypes of other people's perceptions (especially in the context of gender stereotypes).

The group members offer the following instruction: "You should now contact the partners you wanted to work with. You have to sit opposite each other. One of you reaches out your hand so that the other can get to know it well. You have to look it from the sides, touch it, rotate it. Get her size, hand shape, decorate. Trying to evaluate your hand as a symbol and increase your partners' holistic representatives. By my signal, you are changing roles: now your partner should familiarize themselves with your hand. After the exercise, you should make a presentation to your partner (based on your impressions of him /her hand).

After completing the first part, participants are given additional instruction: "now you will be presenting your partner. You should describe what he (s) is characteristic of, based on the impression of learning about his (her) hand. After the presentation, your partner gives you feedback: what is relevant to him (her) in your presentation and what is not, that is, false".

Sharing: Discussion of an activity during which participants give feedback on the experience, impressions, wishes, satisfaction / dissatisfaction with the activity, etc.

\section{Lesson 2.}

Starting from the second lesson, the participants will be offered exercises and tasks aimed at stimulating awareness and understanding of the existing gender stereotypes and discriminatory manifestations in society. The second block (2-9 sessions) enables the individual to recall the events of his or her own life, to analyze them, to highlight the manifestations of gender inequality and gender-based discrimination, to adjust life decisions, to change oneself and their attitude to gender issues. The second block aims to make personal changes to improve the further life path of the person beyond gender restrictive stereotypes.

Exercise "What is affecting my life?": The purpose of the exercise is to highlight the subject of factors that affect his / her life.

Instruction: "Please provide a list of factors (events, people, etc.) that affect your life. Write down everything that comes to mind". 
In the course of the exercise, the participants of the group come to the concept of external (events, other people, etc.) and internal (attitude to certain events, life choices, stereotypical beliefs, etc.) determination of life path. The understanding that a person can influence himself and influence (consciously or unconsciously) on his life is updated. Of particular importance is the awareness of who influences life and how. Were there people who acted outside the established gender stereotypes. How important they were for the band member. What events contributed to the formation of gender stereotypes, and what events, on the contrary, determined the realization that there was something more than existing social expectations. During the analysis of the exercise, the understanding that a person is influenced by the social environment is increasingly formed, but the person is not only a passive recipient of information. Everyone can take an active and transformative activity to make their lives beyond their existing prejudices.

Exercise "Circle of my life": this exercise is aimed at determining the peculiarities of the interconnection of the past, present and future on the life of the individual; definition of subjective experience of this influence.

The trainer gives the group members the following instruction: "On a piece of paper, please draw three circles. Each circle will symbolize a specific time span of your life: one circle is the past, the second is the present, the third is the future. The circles can be arranged as you like. The main thing is that they express your experience of the relationship between the past, present and future. Indicate which time interval a circle corresponds to".

After the participants have drawn the circles, a group discussion of the received psychological material.

Sharing: Discussion of an activity during which participants give feedback on the experience, impressions, wishes, satisfaction / dissatisfaction with the activity, etc.

Lesson 3.

In this session the participants' self-reflection on themselves continues. Personal beliefs (including gender-based ones) are updated, and their impact on the life of the individual is determined.

The trainer invites the participants to perform the exercise "Who am I?", which allows to identify the characteristics of selfperception of personality. 
Participants are instructed: "Please provide answers to this question. Write down everything that comes to mind. Write the statements in the order in which they occurred to you. Please provide at least 10 answers".

Exercise "My (Gender) Beliefs": The purpose of the exercise is to define the gender beliefs of the individual in relation to other people and to himself / herself.

Instruction: "Divide a piece of paper into 3 columns. The first column will contain a list of beliefs about the world around you; the second is the belief in others; the third is self-belief. Write down everything that comes to mind".

Additional instructions: "Now, in each column ( 3 in total), put a" + "or" - "in front of each conviction. A "+" sign if that belief helps you in life, a "-" sign if it interferes."

During the discussion, participants determine what beliefs they have in relation to themselves, other people, and others. They analyze the modality ("+" or "-") of these beliefs. They come to understand the interdependence of our beliefs and the specifics of interacting with the world.

The second part of this exercise is to highlight the gender component of existing beliefs. Among the recorded beliefs, participants are asked to identify those that are determined by the gender component. After completing the task, a group analysis is made of what gender beliefs are available to the group members and how these beliefs affect their interaction with the surrounding world, with other people and with themselves.

Exercise "What is Gender Discrimination?". The purpose of the exercise is to update the knowledge and experience of the group members on the subject. The trainer gives the participants the following instruction: "Join in groups of four people. Each group receives a large piece of paper on which to reflect what you think when I say, "What is gender discrimination?" It may be a certain image or something else that will embody the phenomenon of discrimination. Work in groups. You have 20 minutes to complete the task. After that we will present the works you have created. “

After the groups have completed the task, there is a presentation of the work done by each group. The presentation takes place in an active form, where each listener can ask questions about the presented material. 
Sharing: Discussion of an activity during which participants give feedback on the experience, impressions, wishes, satisfaction / dissatisfaction with the activity, etc.

\section{Lesson 4.}

In this lesson, participants will create a fairy tale. This form of work makes it possible to determine the peculiarities of the gender component of the human life scenario. In our opinion, the unfolding of a person's life is conditioned by a large number of factors and one of the main ones is the actual life scenario. It is founded in early childhood and operates at an unconscious level. The concept of life scenario was developed by E. Bern in the theory of transactional analysis ${ }^{16}$. Followers of E. Bern, such as C. Steiner ${ }^{17}$ and $\mathrm{H}$. Wickoff ${ }^{18}$ explored different types of life scenarios, in particular gender-based (typical female and male scenarios). That is why in order to understand a person's established gender beliefs, it is important to examine his or her life scenario, especially his or her gender component.

Therefore, in our training course, we invite participants to identify the specificities of their gender scenarios. One of the most appropriate methods for this is the fairy-tale therapy, which actually allows you to plunge into its life-scenario space in a casual form.

Exercise "Fairy Tale: There Was a Girl (Boy)...": Exercise gives an opportunity to explore the peculiarities of the gender component of the life scenario of the group members.

The instruction given to the participants of the training: "Today we will become a storyteller with you. Each of you will write a fairy tale that will have fairy-tale characters with whom certain fairy-tale events will take place. The fairy tale should start with the words " there was a girl (boy)...". The tale must have a beginning (how the hero was born, where and how he grew up, etc.). The following are the main events of the tale. And then the end of the tale. Heroes can have any event. There are no restrictions on the location, timing of the fairytale events. You are the author, this is your work. You create your own fairy tale. Each of you has a piece of paper on which you can write your work. So, let's begin!"

\footnotetext{
16 Берн Э. Игры, в которые играют люди. Психология человеческих взаимоотношений; Люди, которые играют в игры. Психология человеческой судьбы / пер. с англ. Екатеринбург: Литур, 2001. 576 с.

${ }^{17}$ Steiner C. Scripts People Live: Transactional Analysis of Life Scripts. Grow Press: New York, 1990. $332 \mathrm{p}$ $332 \mathrm{p}$.

Steiner C. Scripts People Live: Transactional Analysis of Life Scripts. Grow Press: New York, 1990.
} 
In the process of discussing fairy tales, the question is raised about the relationship between the events in the fairy tale, the main character and the events in the life of the group members. The "reflection" in the fairy tale that concerns the author of the fairy tale is analyzed. Topics that are important to the group members (but not always aware) are updated. The gender component of the personality scenario is raised. There is an analysis of whether there is a difference between what happens in fairy tales with heroes-boys and heroines-girls. What is the role of society, parents, environment. Is a person able to counter these stereotypes? And whether a person is able to rewrite the "fairy tale of life", which he had unconsciously adopted in his own childhood.

Sharing: Discussion of an activity during which participants give feedback on the experience, impressions, wishes, satisfaction / dissatisfaction with the activity, etc.

\section{Lesson 5.}

In this session, participants are offered information on the basics of gender theory, the history of the independence movement and women's rights (suffragettes, feminism). This is a theoretical orientation exercise, the main purpose of which is to familiarize the group members with gender issues $19,20,21$.

This lesson reveals the concept of gender approach and its importance for the further harmonious development of human society. During the training the trainer uses presentations, videos and more. The familiarization process takes place in an easy-to-use format, where each participant has the opportunity to ask questions, or to share their own experiences with the information provided by the facilitator.

Sharing: Discussion of an activity during which participants give feedback on the experience, impressions, wishes, satisfaction / dissatisfaction with the activity, etc.

\section{Lesson 6.}

In this lesson the participants of the training group continue to familiarize themselves with the theoretical basics of gender issues; the legislative background governing this issue in Ukraine is also highlighted.

\footnotetext{
${ }^{19}$ Бем С. Линзы гендера: Трансформация взглядов на проблему неравенства полов / [пер. с англ.]. М.: «Российская политическая энциклопедия» (РОССПЭН), 2004. 336 с.

${ }^{20}$ Говорун Т.В., Кікінежді О. М. Стать та сексуальність: психологічний ракурс. Тернопіль: Навчальна книга - Богдан, 1999. 343 с.

${ }^{21}$ Шевченко 3.В. Словник гендерних термінів. Черкаси: видавець Чабаненко Ю., 2016. URL: http:// a-z-gender.net/ua/\%D2\%91ender.html (дата звернення 22.08.2019).
} 
Gender Quiz Exercise. At the beginning of the class, participants are asked to take a quiz with questions related to the training topic.

The trainer offers the participants the following task: "Now we will become participants of the quiz! I will put the question on the interactive whiteboard, and you will choose the answer that you think is correct. There will be ten questions in total, which means you can score 10 points (there is one point for each correct answer). So let's get started!"

Additional instruction: "We will now check with you the correctness of our answers. So, let's look at the screen and check our answers with the correct answers".

The participants then share their results and discuss the results. There is an exchange of views as to whether the members of the group are sufficiently aware of the gender issues being addressed at the legislative level.

The quiz is followed by an information block that outlines the main legal documents that should ensure gender equality in Ukraine. It is emphasized that in Ukraine gender equality is enshrined in the Basic Law of Ukraine - Constitution ${ }^{22}$.

Successful examples of regulation of this issue in other countries of the world (Sweden, Canada, USA) are also described.

The information block concludes with examples of advocacy campaigns aimed at addressing discrimination against women and established discriminatory social stereotypes.

For example, you might suggest the video, "Why does being a girl mean bad?" (\#LikeAGirl) ${ }^{23}$. As well as video campaigns that highlight the importance of preventing gender-based discrimination (\#HeForShe) ${ }^{24}$. After watching the video, there is a discussion about how social stereotypes affect how we perceive people and how people perceive themselves (especially in the context of gender stereotypes) ${ }^{25,26}$.

The group member is given a homework assignment: "Please find further examples of advocacy campaigns that have raised issues of

\footnotetext{
${ }^{22}$ Конституція України. URL: https://zakon.rada.gov.ua/laws/show/254\%D0\%BA/96-\%D0\%B2\%D1\%80 (дата звернення: 19.08.2019).

${ }^{23}$ \#LikeAGirl https://always.com/en-us/about-us/likeagirl-how-it-all-started (дата звернення 22.08.19)

${ }^{24}$ \#HeForShe https://www.heforshe.org/en (дата звернення 21.08.19)

25 Шевченко 3.В. Словник гендерних термінів. Черкаси: видавець Чабаненко Ю., 2016. URL: http:// a-z-gender.net/ua/\%D2\%91ender.html (дата звернення 22.08.2019).

26 Куравська Н. Гендерні стереотипи як джерело гендерної дискримінації та сексизму. URL: file://D:/ГЕНДЕР2019/3729-10766-1-SM.pdf (дата звернення: 21.08.2019).
} 
discrimination against women and the oppression of their rights. At the next session, each of you will present the information you have found".

Sharing: Discussion of an activity during which participants give feedback on the experience, impressions, wishes, satisfaction / dissatisfaction with the activity, etc.

\section{Lesson 7.}

At the beginning of the class, participants share examples of advocacy campaigns (sixth class homework) that raise issues of gender inequality and discriminatory behavior.

This is followed by a main unit of study aimed at reflecting on the trainees of what it meant to be a woman of the past. The issue of lack of rights and freedom for women, which has prevailed over much of the globe and continues to this day, is still being updated. The deepening of this issue is proposed to be made using one of the methods of non-formal education - the method of theatrical decision.

Exercise "Theater". The trainer offers the participants the following instruction: "You will now join into four groups. Each group will receive a leaflet that will spell out a certain historical period. Your job is to make a mini-play that would show the situation of women during the historical period indicated on the card. You have 40 minutes to complete the exercise (information search and production scenario)".

In order for the participants to be able to make such a resolution, they need to know: what happened to women at that time; what rights did they have (or vice versa, did not have)? This exercise helps to increase the level of activity of participants of the training group. Because they need to find the information they need. The trainer can only direct, provide clarifying information, etc. However, the information itself should be sought by participants. To do this, they must use smartphones with an Internet connection.

Searching for information leads participants to realize that at all times (in our example, we wrote on the cards such periods as: Antiquity, Middle Ages, Renaissance, Modern Times), women actually had no rights and were the "property" of male relatives. Such an opening actualizes the understanding that as it is now, it has not always been so. There have been times when women had no right to go outside the home without the support of men, that they had no rights to children, had no property rights, and no voice. Such an opening is usually quite emotional. And here it is 
very appropriate to use the method of theatrical production, since the participants have to translate their knowledge into a certain form, which should convey the information received to the audience who will watch this performance. To do this, participants need to "get on" in the role and truly feel the oppression that women have been in all this time.

Additional instruction: "Each group is now showing its miniperformances. And other participants have to guess what the historical period is all about!".

Following is a presentation of the performances. After all the groups have presented their performances, there is a collective discussion of what the participants saw, found and experienced.

Sharing: Discussion of an activity during which participants give feedback on the experience, impressions, wishes, satisfaction / dissatisfaction with the activity, etc.

\section{Lesson 8.}

This lesson continues to reflect on how women have lived in the past and what has happened in the course of the historical development of society, so that women can enjoy the rights they have today, including voting rights.

Movie Watch Exercise. The trainer offers the participants the following instruction: "In the last session, we learned about what women could do in different historical eras and what rights they were guaranteed (or, more appropriately, not guaranteed). At today's session, we will be watching the movie "Suffragette" (directed by Sarah Gavron, 2015), which will tell us about women's right to vote in the elections". After that there is a collective viewing of the movie.

At the end of the viewing, a discussion unfolds about what the participants saw in this movie. Each participant shares the impression they have seen. There is an analysis of whether the methods used by suffragettes were appropriate. How would you do in the place of the main character of the film: what would you choose a family or fight for women's rights?

After the discussion, the participants of the training group are given a homework task: to write an essay on "The value of the suffragette movement for gender equality."

Sharing: Discussion of an activity during which participants give feedback on the experience, impressions, wishes, satisfaction / dissatisfaction with the activity, etc. 


\section{Lesson 9.}

The purpose of this lesson is to create a gender advocacy campaign for the training group.

Exercise "Advocacy Campaign". The trainer offers the participants the following task: "Remember, in one session, we talked to you about legislative support for gender equality in countries. In addition, we have looked at advocacy campaigns to raise public awareness of discriminatory practices against girls and women. In particular, we were introduced to the \#HeForShe and \#LikeAGirl advocacy. Each of you also presented other examples of advocacy campaigns on gender issues. That is why today we will develop our own advocacy campaigns, which should help to reduce the level of discriminatory manifestations in Ukrainian society".

Additional instructions: "You will now join groups of 5 people. Each group must develop an advocacy campaign that the group can do on its own. Therefore, an advocacy campaign should include the following elements:

- the name that should be related to the topic you chose (in our case, it's gender);

- motto (slogan) - a short sentence that should show the main appeal for the people who will see it;

- campaign stages (stages that include a campaign: preparatory, actual campaign, analysis of results, etc.);

- deadlines (terms of campaign implementation);

- responsible persons (who is responsible for the timing and quality of implementation of the advocacy campaign in "life");

- venue and form (where exactly the campaign (village, city, region) will take place and what form it will take: online or offline);

- target audience (who this campaign is targeted to, who should "hear it").

So, you have a support scheme to help you develop your advocacy campaign. Each group has a poster and pencils where you have to mark the strong points of your campaign. So, get to work!".

Participants work in a group, the trainer can help and answer questions that may arise in the participants during the exercise.

Then the participants present their projects. Each group takes the stage one by one and talks about their campaign, drawing on the supporting 
scheme. Other participants listen carefully and ask clarifying questions. After the presentation, the results are discussed.

At the end of the class, there is a sharing: a discussion of the class, during which the participants give feedback on the experience, impressions, wishes, satisfaction / dissatisfaction with the lesson, etc.

\section{Lesson 10.}

The tenth session is the final stage of the training course "Gender (in) equality: I can do more!" The last lesson is summing up the participants of the group and its trainer. The final lesson reflects the experience gained, information on gender issues, outlines possible ways of further functioning of the individual beyond gender stereotypes. However, the final lesson aims not only to summarize, but also to encourage participants to integrate their knowledge and experience into their later lives.

Exercise "Collective experience". The trainer offers the participants the following task: "Today we have the last lesson of our training course with you. Not only did we get a lot of information and knowledge from you, but we also gained experience that could only be born during group interaction. Now, let us each draw / write something on this sheet of paper that he or she has associated with this experience. We work in complete silence".

After all the participants have completed the task, an analysis takes place. Each participant speaks of that symbol (word) that he/she depicted on this paper. Describes what it means to him/her and why he/she painted / wrote it. As a result, we get impressions of the training course.

Exercise of "Wishes for Yourself": actualization of the subject's wishes for himself and his subsequent life in the context of interaction with gender issues.

The trainer offers the participants the following instruction: "In the course of our lessons we have analyzed the situation in the society on gender issues. They researched what happened to gender discrimination at different historical stages of society. Find out which women's movements contributed to women's right to vote, and later other basic human rights. Understand how strong are the gender stereotypes that are attached to society by a person from the very beginning of his / her life. In addition, we have developed advocacy campaigns to raise public awareness of gender inequality. 
Now, based on the knowledge you have received, on the emotions you have experienced, complete the following task. On a piece of paper, write what you wish for yourself, what would you like to do in the future?".

Group Gratitude Exercise: End contact in the group.

Instruction: During our training, we made a lot of discoveries about ourselves, as well as other members of the group. We have gained group experience. And we got this experience thanks to each of the group members. Now we will do the last exercise of our training. We will pass a candle in a circle and each of you should give the band and its members a specific wish.

After completing this exercise, training ends.

The proposed structure of a gender-specific training course for working with young people (students) can be used in various higher education institutions (public, private, communal). The training can be provided in the form of an elective, or as a course of the variant part of the curriculum. In addition, coaches / psychologists / teachers can take individual exercises from this course for their training and practical activities. This structure is basic and can be supplemented according to the requirements of each individual group.

\section{CONCLUSIONS}

As a result of a scientific search, we have developed the basic structure of a gender-based training course for working with young people.

Based on the psychological characteristics of the age category of students (young people) and the specifics of working in a group format, we have developed a basic training scheme. In particular, it was determined that a training pro gramme on gender inequality in general should include the following structural elements (blocks): block 1 (1 lesson) - getting to know the group; block 2 (2-9 lessons) - acquaintance with basic concepts of gender theory, definition of basic gender stereotypes, reflection of participants' experience, which included gender-based discrimination; understanding the possibility of changing stereotypes and choosing to go beyond them; building a future plan for combating gender-based discrimination and establishing gender equality; 3 block (10 lessons) completion of training work.

The training course may contain exercises that will allow young people not only to receive information but also to experience it (for 
example, the Theater exercise). This increases the level of assimilation of the acquired information. In addition, information obtained in this way becomes the subject's "own" experience, which increases the level of its significance for the individual.

To encourage young people to be active in the training course, they include exercises that require students to take action to raise public awareness of gender issues (Exercise Advocacy Campaign).

The proposed basic structure of the training course can be used entirely by trainers / psychologists / teachers, or parts (using separate exercises in accordance with educational and pedagogical needs).

This training does not reveal all the possible approaches to working with young people (students) in the context of gender issues. However, we hope that it will come in handy when developing other training / training courses.

\section{SUMMARY}

This article is dedicated to the features of the development of genderspecific training courses when working with young people.

Attention is drawn to the fact that implementation of these courses is of particular importance in the context of the European vector of development of the Ukrainian state. It has been determined that there is a legal framework in Ukraine that regulates gender and promotes gender equality (starting with the basic law - the Constitution of Ukraine).

The work emphasizes the need to introduce training and training courses on gender orientation as a prerequisite for harmonious personal development.

It has been stated that self-awareness (including gender-based stereotypes) will be effective when it occurs at three levels: cognitive (information block), emotional-motivational (experience, attitude towards it) and includes a volitional component (my actions, aimed at changing the current situation). Therefore, the training should use exercises that cover all the specified areas of the human psyche.

The basic structure of a gender-specific training course for working with young people (students) is proposed, which can be used during the educational process, in the form of an elective or a part of a variant part of the curriculum. 
It is emphasized that psychological support for personality development cannot take place outside of gender issues, since gender issues accompany a person throughout their lives and are manifested in all spheres (social, household, economic, political, etc.).

\section{REFERENCES}

1. Абрамова Г.С. Возрастная психология. Екатеринбург: Деловая книга, 1999. $621 \mathrm{c.}$

2. Бем С. Линзы гендера: Трансформация взглядов на проблему неравенства полов / [пер. с англ.]. М.: «Российская политическая энциклопедия» (РОССПЭН), 2004. 336 с.

3. Берн Э. Игры, в которые играют люди. Психология человеческих взаимоотношений; Люди, которые играют в игры. Психология человеческой судьбы / пер. с англ. Екатеринбург: Литур, $2001.576 \mathrm{c}$.

4. Божович Л.И. Проблемы формирования личности: Избр. психол. тр. / Под ред. Д.И. Фельдштейна; Рос. акад. образования, Моск. психол.-соц. ин-т. - 3-е изд. М.: МПСИ. 2001. 349 с.

5. Вачков И. Основы технологии группового тренинга. М.: Издательство «Ось-89», 1999. 256 с.

6. Говорун Т. В., Кікінежді О. М. Стать та сексуальність: психологічний ракурс. Тернопіль: Навчальна книга - Богдан, 1999. $343 \mathrm{c}$.

7. Конституція України. URL: https://zakon.rada.gov.ua/laws/show/ 254\%D0\%BA/96-\%D0\%B2\%D1\%80 (дата звернення: 19.08.2019).

8. Климчук В.А. Тренинг внутренней мотивации. СПб.: Речь, 2005. $76 \mathrm{c}$.

9. Куравська Н. Гендерні стереотипи як джерело гендерної дискримінації та сексизму. URL: file://D:/ГЕНДЕР2019/3729-10766-1SM.pdf (дата звернення: 21.08.2019).

10. Леви В.Л. Искусство быть другим. Л.: Глобус, 2000. 254 с.

11. Леви В.Л. Искусство быть собой. Л.: Глобус, 2000. 254 с.

12. Малкина-Пых И.Г. Справочник практического психолога. М.: Изд-во Эксмо, 2007. 784 с.

13. Перлз Ф. Практика гештальттерапии. М.: Институт Общегуманитарных Исследований, 2005. 480 с. 
14. Райс Ф., Долджин К. Психология подросткового и юношеского возраста. СПб.: Питер, 2012. 816 с.

15. Рамендик Д. М. Тренинг личностного роста. Изд.: Форум, 2007. $82 \mathrm{c}$.

16. Як навчати школярів долати гендерні стереотипи: конспекти занять / навч.-метод. посібник для загальноосвітніх навчальних закладів. Т. Говорун, О. Кікінежді та ін., за заг.ред. професора Т. Говорун. К.: ТОВ «Дорадо-Друк», 2006. 804 с.

17. Фопель К. Психологические группы: Рабочие материалы для ведущего: Практическое пособие. К. : Пер. с нем. 2-е изд., стер. М.: Генезис, 2000. 256 с.

18. Шевченко 3. В. Словник гендерних термінів. Черкаси: видавець Чабаненко Ю., 2016. URL: http://a-z-gender.net/ua/\%D2\% 91ender.html (дата звернення 22.08.2019).

19. Ялом И. Групповая психотерапия. Теория и практика. М.: Апрель Пресс, Изд-во ЭКСМО-Пресс, 2001. 576 с.

20. \#HeForShe https://www.heforshe.org/en (дата звернення 21.08.19)

21. Jackson, Philip W. Classroom society. Life in classrooms. New York: Holt, Rinehart and Winston, Inc., 1968, 177 p.

22. \#LikeAGirl https://always.com/en-us/about-us/likeagirl-how-it-allstarted (дата звернення 22.08.19)

23. Steiner C. Scripts People Live: Transactional Analysis of Life Scripts. Grow Press: New York, 1990. 332 p.

\section{Information about the author:}

Kostina T. O.

Candidate of Psychological Sciences, Associate Professor at the Department of Psychology and Pedagogy of the V. I. Vernadsky Taurida National University 33, John McCain str., Kyiv, 01042, Ukraine 


\section{THE POST-TRAUMATIC GROWTH AS THE FACTOR OF PERSONAL DEVELOPMENT IN CONDITIONS OF MODERN UKRAINE}

\section{Kostiuk O. I.}

\section{INTRODUCTION}

According to researches in the developed countries, in particular, the USA, $60 \%$ of the population faces traumatic events at least once, in their life, about $13-17 \%$ has experienced 3 or more situations. Talking about military-conflict zones, the amount of people who have experienced traumatic situations there reaches $92 \%$. The historical heritage of the Ukrainian people only for the last century includes Famine-Genocide and deportation to Siberia, the II World War and Soviet period repressions, an explosion of the Chernobyl nuclear power plant and of course contemporary war with Russia. There are no researches, which would record statistics of psychotraumatic events distributed among the population of Ukraine, but concerning the number of traumatic causes embracing modern Ukraine we can assume that our country is closer to those statistics, which are observed in hot spots of the planet. The sociopolitical situation in Ukraine puts new challenges in front of psychologists. Demolition of an old totalitarian system and the long transition period from Post-Soviet inheritance to finally creating the democratic society is complicated by external aggression which affects all aspects of life in Ukraine and not only in those regions that suffer from military operations.

Unfortunately, there is not only the problem of historical mass injuries and their transgenerational transmission in Ukraine but also the problem of actual psychotraumatic events that have neither social protection against them nor recovery programs for those who eventually had PTSD. For example, women who became victims of domestic violence or sexually and physically abused children. This situation has lead to PTSD symptoms being written into cultural norms of the nation and unfortunately, those norms are far away from the actual psychological standards. There are some spread phenomena in Ukrainian society that to our point of view are 
the demonstrations of "PTSD of the national coverage" (metaphor made by UCU's mental health institute).

Those phenomena are:

Very strict, sometimes even violent rules of behavior for children in public places that give no space to a child for self-development. Oppressing the activity of the child is not based on safeness but on making one more comfortable, invisible for strangers and relatives.

Dividing up the society on "my people" and "strangers" that leads to cautious or aggressive behavior towards those who received a marker "strangers".

Having reduced interest in new opportunities and facing difficulties with choosing something new.

Behaving in learned helplessness style, having a high level of mistrust for people, new initiatives, ideas and their realization, preferring well known and usual not something better.

Being oriented towards someone else's interests and behavior, not your own that leads to becoming extra loyal to the government and forgetting about personal concerns.

Dichotomous behavior: going easy from 'victim' position to 'aggressor' position and total lack of assertiveness.

That is why the problem of adaptation disorder that was caused by stress or traumatic situation and the ways to overcome it has become the subject of heightened interest among psychologists. The clinical picture of various adaptation disorders caused by psychological trauma is in detail investigated and brought to deep understanding nowadays, it is known how the person overcomes a trauma and what factors determine the process, the process itself and a possibility of intervention in it including psychotherapy.

Regardless, this pathologizing approach of consideration the psychological trauma has some barriers that prevent solving the problem. V. Klymchuk states: "by focusing on disabilities and their therapy we risk to:

To stigmatize by automatically putting a PTSD label on everyone who has ever dealt with trauma. To use wrong or unneeded interventions.

To not notice or ignore positive changes that have happened to a patient, for example rethinking their life position or appreciating it more, having a feeling of gratitude, etc. 
To lose faith in the ability of mentality to recover by just having social and psychological support from patient's closest people, society and government.

To take too much pressure on yourself while worrying about a patient's mental wellness, without sufficient resources that would help to overcome it and eventually will be lead to emotional burnout.

In the last couple of dozens of years the explorers of psychological trauma started to notice a few new things:

About $70-80 \%$ of people overcome the consequences of psychological trauma without professional help.

Overcoming traumatic events often leads to positive changes in the life of the patient.

Both of these empirical observations made the researchers change the focus from concentrating on destructive consequences caused by stress into focusing on positive aspects of this process.

The first observation has generated research on the phenomenon called 'resilience', which can be explained as the ability to be happy again after something difficult has happened. It is based on one empirical fact that people are capable of recovering by themselves and that they have all the needed resources.

The second observation is focused on research about what particular positive changes and new opportunities become available while dealing with psychological trauma.

The research about this kind of post-traumatic transformation has rather young history and as well as the 'resilience' concept it has lots of synonyms: positive psychological changes, positive side effects, transformational coping, prosperity but still the main concept is posttraumatic growth.

It is important to state the difference between these two concepts. The resilience itself and all the researches that were made on it are based on a disposition of the personality towards their attitude for other people, themselves and the world in general. It is a productive way in today's research, and the practice based on it not only allows shaping the strong character but also heightens the level of effective functioning despite difficulties.

Unlike resilience, the term posttraumatic growth is a qualitative change in the functioning of the person. The change happens when a 
person faces a struggle that requires a higher level of strength to overcome it, which makes one review their life position, their attitude to others and their relationship with themselves. Facing psychotrauma allows realizing that some moments in our life cannot be controlled; they are unpredicted and can, of course, cause a feeling of helplessness and hopelessness. This is exactly what pushes people to post-traumatic growth.

All European and eastern culture, philosophical, religious and literary works claimed that struggle always leads to a better understanding of life and yourself. Despite the previous fact it became a subject of scientific research in psychology not a long time ago.

\section{The development of post-traumatic growth}

It is difficult to state who were the actual pioneers of the posttraumatic growth concept but we can surely state that dr. N.Finkel (1975) was one of them. He studied post-traumatic experience on his students and noticed that most of them talked about the positive outcome of the struggle. Dunning and Silva (1981) in their research stated that by experiencing negative events people start to reevaluate their priorities and are capable of overcoming struggle faster in the future. Aldwing, Lewenson, and Spiro (1994) had a different approach. They studied coping strategies of overcoming stressful, traumatic situation and crises and recorded three types of coping:

- The one that leads to balance renewal

- The one that leads to negative transformation during which the person denies their acquired level by that time.

- The one that leads to positive transformation and allows getting new qualities.

As we see, in this case, the post-traumatic growth is considered as the third type, the adaptive mechanism that leads to positive transformation after overcoming stress. Maercker and Zoellner's (2006) research also states the significant correlation between posttraumatic growth and adaptation. The authors consider growth as a two-component process, the first component of which is a functional coping, based on overcoming fears and bars, also the revaluation of the principles and having a different point of view on the particular situation, being able to overcome the crisis. The second component is illusory coping, based on avoiding the crisis, 
diverting from a traumatic situation. The person is focused not on overcoming a situation but on distress removal.

O'Leary, Alday \& Ickoviks, 1996, offered a similar model based on empirical researches. They consider a traumatic event as an interruption of usual functioning. Thus, the results of overcoming the traumatic situation can be the following:

- The lower level of functioning than before a trauma - survival

- Returning on the previous level of functioning - renewal

- Reaching a higher level of functioning - prosperity

The last option, namely prosperity, is the author's understanding of how an exit from a traumatic situation looks like before growth.

The term "posttraumatic growth" became common after Tedeschi and Calhoun, 1996 research. They explain it as the positive outcome reported by the people who have experienced traumatic events. At first, they describe the positive experience as growth, comparing to the previous level and significant transformation that happens to a person at least in three spheres: strengthening their perceptions of self, others, and the meaning of events. There are five main parameters of post-traumatic growth which are presented in their scale: New Possibilities, Relating to Others, Personal Strength, Spiritual Change, and Appreciation of Life.

Researchers state that post-traumatic growth conducts positive self-perception, confidence, and the ability to overcome crises, increases self-trust, ability to accept difficulties, and imperfection of the world in which live. It is very important to note that not only self-confidence, determination, and feeling of mental strength are the result of posttraumatic growth, but also understanding of personal weaknesses and restrictions. The interpersonal relations also change, there is a higher level of selectivity, and some of the relations that happened before the trauma get broken up or almost broken up, on the other hand, family relations or relationships with close people get better, become stronger and what is important they are valued more. A further component of the interpersonal elements of posttraumatic growth is the experience of a greater sense of compassion for others who experience life difficulties. The transformation of life philosophy due to posttraumatic growth expresses itself in the higher level of life valuation, realization of new possibilities, and making better life choices. Religious, spiritual, and existential components of life get more attention too. 
Tedeschi \& Calhoun's model of posttraumatic growth is a functionally descriptive model that is based on the socially cognitive processes of the person who faced psychological trauma. Posttraumatic growth appears as the result of the cognitive process in this model, the result of revaluation and reconstruction of ideology that was made based on traumatic experience. There are two terms made by R. Janoff Bulman "ready for action" and "assumptive world" that play a big role in this model. She stated that people who faced psycho trauma are capable of reacting to the crisis more calm and confident because there is a new addition to the "assumptive world" of this person like the possibility of getting injured, losing someone close, bankrupting, natural or technical accidents. Assuming this factor, people who have ever faced psychological trauma are more confident in non-standard situations and ready to solve the problem right away.

Joseph has a different point of view, he states that posttraumatic growth is a process that leads to congruence the "I" concept and new traumatic experience, that it is a process of reintegrating the new sides of the personality caused by trauma that will eventually lead to deepening the "I" concept. The reintegrating process can go two ways, the assimilation of new knowledge or it's accommodation. The accommodation is the main mechanism, which provides ideology change, and it's deepening while posttraumatic growth. The major point of accommodation is meaning. The cognitive processing of trauma is processed by giving it a meaning. The person looks for the reason at first but after looks for the sense of what they have been through. Joseph's model of the posttraumatic disorder is personally centered. It is based on Rogers's humanistic theory. This concept is based on posttraumatic growth as a natural process provided by our organism that is directed on actualizing its potential in a way of accommodation and cognitively processing a traumatic experience. The need for self-improvement and self-actualization is the main source of posttraumatic growth. The evaluation of traumatic experience, whether it had a positive or negative impact on self-actualization is the navigator in this process due to "organismic valuing theory".

The next model is a bio-psycho-social model of posttraumatic growth made by Christopher. According to this model, posttraumatic growth is the inherited meta-study mechanism. This mechanism is activated when a person needs to change their meta scheme in new conditions. This way the 
researcher emphasizes the evolutionary meaning of posttraumatic growth, which provides the adaptive process of humankind's development in the history on one side and the biological base on the other side. Christopher points out that the natural, biological reaction to traumatizing events can go either PTSD way or posttraumatic growth way. One of the main factors that have an impact on which way it is going to be is a connection with the environment. The same symptoms can become either pathologizing or they can become a basis for self-growth. For example concentration on triggers can be a starting mechanism for intrusions, ruminations, flashbacks or panic attacks or it can become a signal system that will help to avoid some unpleasant situations in the future. The biological system side of a person's connection with the environment changes very slowly in contrast to the socio-cultural system, which needs more flexibility and time for adaptation due to the speed. This exact conflict makes people vulnerable and can trigger the process in PTSD way. Christopher shows how to escape this situation by changing the cognitive schema of the personality; he states that we need to develop neuron connections of neocortex and brain in general because of the influence on hypothalamic-hypophyseal-adrenal axis in this particular situation is highly unlikely.

Just like in the previous model the major point of posttraumatic growth is to find meaning. The process of meta-study, the formation of the new ideology and new priorities can be started by transforming anxiety into sense. Posttraumatic growth changes the personality in a way that is close to social solidarity and support; the change of "I" concept, integrative and deeper thinking. PTSD, on the other hand, is based on avoiding social groups, breaking connections with people, isolation, and concentration on negativity and toxic experiences. Christopher also points out that not only the environment impacts posttraumatic growth but the growth itself changes the environment. PTSD and posttraumatic growth are both based on biological mechanisms, only posttraumatic growth is a more natural reaction to stress. Both of the reactions make an impact on biological, psychological and social levels and depend on the combination of physical health, mental health, and socio-cultural context. Christopher insists on the fact that cognitive work is the most effective way to work with a traumatizing situation.

All the aforementioned researches about posttraumatic growth show the process from the evaluative side and cognitive structure of the 
individual. Christopher's model is made in the most complex and highlevel style but mostly points to biological aspects. It is paradoxical that when the author mentions different posttraumatic growth mechanisms he ignores those biological aspects and only talks about neocortex.

Levin P. in his works reviews the recovery after trauma from a totally different side, he claims that it is the process of corporal, psychological and spiritual health awakening to be specific. He also says that the main principle for recovery is a somatic experience. Levin states that psychological trauma happens when the natural response of our organism to stress factors was stopped or blocked. He reviews the natural response to stress as a "hit and run" theory, the basic coping strategy. The energy produced for a fight or getaway that was not used leads to the appearance of trauma symptoms. It is possibly enough to just let emotions come out and show your inner instincts to get over the trauma. A full recovery is possible only by working with your body through the somatic experience. By somatic experience, P.Levin means corporal feelings that were experienced in the moment of trauma or after the trauma, living through them in the actual moment, activation of those feelings or their deactivation. It is the way of talking to your body that has the main symptoms of the trauma but also the answer to how to get away from it. Feeling something with your body activates corporal feelings that were blocked because of trauma, it ends them and transforms the person itself.

The theoretical basis of this method is the existential approach and psychosomatic principle of human unity. The energy that was blocked because of symptoms, that eventually got free and was mobilized in the right direction cannot just heal the trauma but also transform a human and bring them to new heights. From Levin's point of view, trauma is the existential challenge for ordinary life, it puts a task in front of a person- to change ordinary. Overcoming trauma awakens blocked and hidden strength inside a human. This way trauma can be considered as a chance given to a person for transformation and changing their ideology. Levin does not use the term posttraumatic growth, he says "posttraumatic awakening" specifically talking about mental, social and spiritual awakening. The important aspect of awakening is that it can change not just the person itself but also their environment. On one side, the feeling of empathy for a traumatized person is one of the resources for the awakening, on the other side awakening is the start for social 
transformation. The main thing is that those processes generate the new quality of social relations, which Levin calls "empathy presence" relationship.

Levin's approach gives us the model of posttraumatic growth from the side of the biological system, it points out at unblocking the hypothalamichypophyseal-adrenal axis and using the energy that got free for awakening and personal transformation. By speaking to the body and awaking the corporal strength and energy the somatic way of overcoming trauma also awakens spirituality.

Levin points out that unity of the body, consciousness, and spirit, can heal not just one personality but the whole community. He says that the person who awakened after a traumatic experience can be the initiator of socially important changes.

It is also important to say that the positive transformation of those who have overcome trauma does not necessarily exclude PTSD symptoms or comorbid disorders (depression, anxiety, OCD). Many studies show that they can exist together.

(Aldwin C., Levenson M., Spiro A., 1994; Joseph et al., 1993; Tedeschi \& Calhoun, 2004, Hobfoll, Tracy, \& Galea, 2006).

The integration of Ukrainian scientific psychology into world psychology and the aspects of Ukrainian entity have risen the interest in posttraumatic growth among Ukrainian scientists. The posttraumatic growth was described in the works of the following Ukrainian psychologists: V. Horbunova, D. Zubovsky, V. Klymchuk, V. Osyodlo, I. Prykhodko, O.Sheluh, S.Chachko. Many kinds of research and practical developments about posttraumatic growth made by Ukrainian psychologists are in the starting position. The following models that have been listed in this chapter reveal the different aspects of the process and complete each other, not compete. The completed integrative model of posttraumatic growth is still in the future.

\section{Determinants of posttraumatic growth}

The research of determinants that impact posttraumatic growth is a very important aspect. They allow us to find out different ways of possible influence on the process. The main determinants which were discovered during researches are:

- The intensity of stress factors 
- Psychological characteristics of the personality

- Cognitive organization of the personality

- Behavior patterns of the personality

- Social determinants

- Gender specialties

- Emotions etc.

The list is not full. We do not know how the duration and periodicity of the stress factors influence posttraumatic growth, but we can assume that it has some impact.

The intensity of stress factors and their impact on posttraumatic growth is disputable, some researchers state that the connection between them is nonlinear and has $U$ shaped curve which means that a small amount of stress leads to the assimilation of new experience and small ideology changes. Excessive stress, on the other hand, leads to disadaptation. The medium amount of stress is the most effective for posttraumatic growth. (Calhoun \& Tedeschi, 2004; Carver, 1998).

More reserchers assume there is a linear connection between the intensity of the stress factor and positive personality growth. This point of view finds lots of proof in military cases: the shot power is directly proportional to the number of positive changes. Elder 1989; Aldwin, McMillan, Smith, Fisher, 2001; Park, Cohen \& Murch, 1996; Fontana, Rosenheck, 1998)

The research made on the connection between individual psychological characteristics and posttraumatic growth shows the correlation between extraversion, the ability for positive thinking and being open to new experiences. Posttraumatic growth is also connected to the religiosity of the person who has experienced psychotrauma. It was also discovered that the functional growth of the personality could be correlated with resilience, open mind and integrity as much as the feeling of belonging to the community. The disposal of optimism and internal locus of control have linear dependence with adaptive and illusory posttraumatic growth.

Calhoun \& Tedeschi state that posttraumatic growth can be reached through processing traumatic experience with cognitive mechanisms. Primary cognitive processing happens through obsessive thoughts and recollection of traumatizing events that happen in a form of intrusions, ruminations, and flashbacks. It is also called the distress phase. When the 
distress level lowers, the cognitive work continues as random reflections. It is also stated that dialectical thinking and cognitive complexity have a positive impact on posttraumatic growth.

In an affective-cognitive processing model of post-traumatic growth described by Joseph, the self-concept and its world model are the main structures for the cognitive process. As it was already stated, the integration of the past into old constructs characterizes the process of renewal, but the rearrangement of those constructs is the posttraumatic growth itself.

The cognitive processing of the crisis is better described by Dorozhovets, who states that it goes in three different ways.

- Finding a meaning that leads to ideology change.

- The desire to bring back control under the situation which allows recovering the adaptive mechanisms.

- An attempt to recover the self-appraisal that was lowered because of trauma which leads to the self-concept change.

Illusions play an important role in this concept. The person who allows those illusions to evolve and supports them in front of traumatic events is more effective.

Solomon, who made a research on military men who have been freed after the captivity, she marks that coping behavior while captivity had a positive impact on personality that was shown after they came back home.

Affleck\&Tennen describe the components of coping behavior in detail. It includes positive reframing, the ability to distract yourself from traumatic events and then come back to find the solution later, make an effort to fight the situation even though it is useless, the ability to ask others for help. Each of these aspects increases the chances of posttraumatic growth.

The social determinants of posttraumatic growth can be divided into two groups

The closest environment, friends, family, etc.

Socio-cultural community, social networks, culture, and traditions.

Joseph was the one who has pointed on the importance of social support.

Calhoun \& Tedeschi state that social support is the main factor of posttraumatic growth and that it has a few elements to discuss. Is the person ready to open to the closest people and their environment? Are 
those people ready to listen, discuss and help the one who has faced trauma?

The cooperation with the closest environment and referent groups has to be overviewed wider. For example, while discussing the psychotrumatic event that happened to a person people can add cultural templates and examples, the example of someone who has faced and eventually overcame trauma is very important in a socio-cultural context. The other posttraumatic growth researcher whose name is D.McAdams thinks that posttraumatic growth is highly affected by American narrative, moreover, the process of opening to the public and the perception of this opening by the people happens in frames of these specific American narratives.

The cultural influence on the process of posttraumatic growth is still not very well researched, the main focus lies on the way the socio-cultural context influences positive and negative aspects of opening to the big social groups and more limited ones. Social support plays one of the main roles in the process of posttraumatic growth. Many researchers point out that the role of social support is brightly lightened in the studies that were made on military captives or people who have suffered war actions. D.S. Zubovsky says: ... the military men who come back home get different social reactions that eventually can play a very important role in further readaptation and become the basis for positive personal change. The positive impact of social support on the posttraumatic growth of those captivates who came back home to Israel confirms Z. Solomon's research. She thinks that this fact allows to correct the emotional condition of those who were freed from captivity to the positive side and that gives us an additional recourse for posttraumatic growth. The veterans of the Vietnam war, R.Rosenchek, and A.Fontana demonstrate the importance of social impact on posttraumatic growth from the other side. The positive personal change happened to a solid amount of veterans with almost all kinds of traumas except for those who were aggressive themselves, those had to deal with difficulties while trying to come back to the positive side. The authors state that this paradox is connected to a high level of social justice for particular kinds of actions.

The other side of personal posttraumatic growth from the social determinants point of view is its impact on society. P. Levin's "posttraumatic awakening" model demonstrates that a person who has reached posttraumatic growth brings new quality into a social relationship 
with their environment and becomes an element that inspires social innovations.

S. Joseph and P. Linley bring a concept of social post-traumatic growth. Its main feature is that its main concern is not about the person, but about the community. This phenomenon is recorded in cases where community, social or political group has survived a common struggle: for example technogenic or natural disaster, political violence, tyranny, war or terrorist operations. Social post-traumatic growth is observed in parallel to personal when there are mutual assistance and support in the community with branched out connections and communication, etc.

In his scientific works, Christopher also marks out a higher level of sociocentrism than there was before the trauma, which leads to closer integration with community and more significant interchange. In the case of group trauma, very often the perspective of the whole group changes, they get new paradigms and the principles of the relation with the environmental, social and religious problems.

The Ukrainian researcher V. Gorbunova considers social determinants in terms of possible stigmatization of the person that had a psychological trauma, strengthening of PTSD symptoms and obstacles that can create adverse social conditions for post-traumatic development. She also gives recommendations about creating and setting the mechanisms of social support that can have a positive impact on posttraumatic growth. She considers that one of the important factors for posttraumatic recovery is of course help from relatives and the family, their quiet, non-pathological and supportive attitude.

Gender difference also has a significant influence on post-traumatic growth. Women tend to have a better positive outcome after trauma. Park makes a hypothesis that explains this phenomenon, but not with physiological characteristics that are typical for the particular gender. Park makes a statement that there are different coping strategies for women and men which are widespread in the social environment, and also different approaches to upbringing girls and boys.

The influence of emotions on posttraumatic growth is not well explored. T. Zoyellner, A. Mayerker mark that there is a considerable influence of positive emotions, in particular, the emotional side of being open to new experiences. It can be an important factor in the way of posttraumatic growth, more valuable than cognitive factors. The feeling of 
accessory and gratefulness for trauma highly increases the chance of posttraumatic growth.

Empirical researches on the connection of posttraumatic growth with optimism and pessimism for the people who endured psychotraumatizing events showed that there is more correlation with optimism. Pessimism and posttraumatic growth are also connected though. Therefore scientists assume that optimism and pessimism are separate determinants that can have an impact on posttraumatic growth with different neurobiological mechanisms.

Christopher notes that toxic emotions of shame and fault reduce the probability of post-traumatic growth. R. Rosenchek and A. Fontani's who made researches on the American veterans confirm the same hypothesis.

Tadeski\&Calhoun mention that the stronger the distress is the stronger the need for reorganization ideology is. The strong distress accompanies posttraumatic growth and has a positive correlation with it, but the high level of distress is crucial for the transformation of the ideology.

Despite the large size of works concerning determinants of posttraumatic growth of the personality and community, it is obvious that this subject is insufficiently and unsystematically revealed, the connections and interference of various factors also demand additional researches for full understanding and reflection of their results.

\section{The mechanisms of posttraumatic growth}

Even though we have already mentioned the fact that many researchers of posttraumatic growth have stated that this phenomenon is typical for all people, there are many obstacles in its way. The main reason why is the transition from PTSD to posttraumatic growth so important is very well described by V.Klymchuk. He says that posttraumatic growth is not always provoked by easing the distress but the growth itself lowers the stress level, impacts posttraumatic adaptation and improves physical condition. The fact that was stated above brings up the question about the need to support posttraumatic growth while getting help from a psychotherapist.

Both Ukrainian and world psychologists think that psychotherapy can be one of the main mechanisms for posttraumatic growth.

Following the idea of Tadeski \& Colhoun, V. Gorbunova points on the importance of social support for posttraumatic growth, which to her 
mind plays a key role in this process. She has a few ideas for the closest environment of the patient which would help to start the growth; to create emotionally stable space and conditions that would allow her to talk about trauma and come back to it and to reorientate the focus of attention on doing productive and interesting activities.

Tadeski\&Colhoun think that the following mechanism is the facilitation of posttraumatic growth. Joseph has an approach to supporting prosperity: 1) working with the narrative; 2) working with hope and 3 ) working with changes- are the main mechanisms to initiate the transformation in his model.

P. Levin insists on the idea that those mechanisms have somatic character. He has a whole list of tools that could help to include them in the process of recovery and growth through the somatic experience.

Our experience in the field of psychotherapy lets us assume that posttraumatic growth can be activated by using at least some of the determinants listed above. For example by using the instruments for rising up the level of resilience.

We should mark that the topic of mechanisms for posttraumatic growth is the least researched for today and requires much effort but it is very perspective for posttraumatic management.

\section{CONCLUSIONS}

Posttraumatic growth is a natural mechanism that was created to deal with traumatic events. Posttraumatic growth has an individuallypsychological and social dimension. Personal posttraumatic growth cannot be seen only as a personal problem. We don't know all the determinants and mechanisms of posttraumatic growth but we know that socio-cultural content has a huge impact on the way that the person deals with trauma or feels social support, the way that social norms present the examples of facing struggle and the level of feeling like belonging to the community. The outcome of the posttraumatic period highly depends on the conditions made in the society, whether it is going to be stigmatization, growth, reduction or changes. Posttraumatic growth leads to innovation in society. By overcoming trauma a person changes and so do their environment and living conditions.

These conclusions are not final, they point on the importance of the need to continue different researches on posttraumatic growth and its 
practical meaning for personality and society. To find more connections between different elements of posttraumatic growth and their determinants and to look for new mechanisms of this process in a socio-cultural and individual form that can allow bringing the practice of posttraumatic growth to a new level is also significant.

New researches on posttraumatic growth can be very helpful for redirecting the psychotherapy approach to a different path. For example, it can be helpful for the development of new social mechanisms, like government programs for rehabilitation after military actions in eastern Ukraine or victims who were affected by home violence, also for the elaboration of protocols about immediate reaction and support in case of technical and natural catastrophes.

The created models of posttraumatic growth, determinants, and mechanisms presented in both Ukrainian and foreign psychology still need development and systematization.

\section{SUMMARY}

This section discusses the topic of post-traumatic growth as one of the most effective mechanisms for personal development. Here are presented the main directions of researches that were made on posttraumatic growth and modern scientific models of this phenomenon. This chapter demonstrates the fact that post-traumatic growth is a natural exit from traumatic situations as well as the factors contributing to personal development and those that prevent it in the post-traumatic period.

It is stated that pathologizing the personality and focusing on the treatment can stigmatize barriers on the way to posttraumatic growth, but paying attention to posttraumatic growth can influence personal development and the development of the society.

This paper reviews the posttraumatic growth phenomenon based on foreign and Ukrainian studies. Here are described the main attempts to create a model of this phenomenon and the main determinants of posttraumatic growth and their influence on it. This paper also shows the connection between PTSD, posttraumatic growth and resilience and gives a short review of the instruments and conditions for posttraumatic growth. 


\section{REFERENCES}

1. Affleck G., Tennen H., Croog S., Levine S. Causal attribution, perceived benefits, and morbidity after a heart attack: An 8-year study // Journal of Consulting and Clinical Psychology.- 1987. $-{ }^{1}$ 55 . - P. 29-35.

2. Aldwin C.M. Vulnerability and resilience to combat exposure: Can stress have lifelong effects? / C.M. Aldwin, M.R. Levenson, A. Spiro // Psychology and aging. -1994. - № 9. - P. 34-44.

3. Aldwin C., Levenson M., Spiro A. Vulnerability and resilience to combat exposure: Can stress have lifelong effects? // Psychology and Aging. - 1994. - № 9. - P. 34-44.

4. Calhoun L.G. Facilitating Posttraumatic Growth: A Clinician's Guide / L.G. Calhoun, R.G. Tedeschi. - Routledge. 1999. - 184 p.

5. Christopher M.A broader view of trauma: a biopsychosocialevolutionary view of the role of the traumatic stress response in the emergence of pathology and/or growth / M. Christopher // Clinical Psychology Review. - 2004. - Vol. 24. - P. 75-98.

6. Elder G.H. Combat experience and emotional health: Impairment and resilience in later life / G.H. Elder, E.C. Clipp // Journal of personality. - 1989. - № 57. - Vol. 2.- P. 311-341 Erbes C. Posttraumatic Growth among American Former Prisoners of War / C. Erbes, R. Eberly, T. Dikel, E. Johnsen, I. Harris, B. Engdahl // Traumatology. - 2005.№ 11. - Vol. 4. - P. 285-295.

7. Erbes C. Posttraumatic Growth among American Former Prisoners of War / C. Erbes, R. Eberly, T. Dikel, E. Johnsen, I. Harris, B. Engdahl // Traumatology. - 2005 - № 11. - Vol. 4. - P. 285-295.

8. Fontana A. Psychological benefits and liabilities of traumatic exposure in the war zone / A. Fontana, R. Rosenheck // Journal of Traumatic stress. - 1998. - № 11.- Vol. 3. - P. 485-503.

9. Finkel N.J. Strens, traumas, and trauma resolution / N.J. Finkel // American Journal of Community Psychology. - 1975. - Vol. 3 (2). P. 173-178.

10. Hobfoll S.E., Tracy M., Galea S. The impact of resource loss and traumatic growth on probable PTSD and depression following terrorist attacks // Journal of Traumatic Stress. $-2006 .{ }^{-1} 19$ (6). - P. 867-878.

11. Joseph S. Client centred therapy, posttraumatic stress disorder and posttraumatic growth : Theoretical perspectives and practical implications / 
Stephen Joseph // Psychology and Psychotherapy: Theory, Research and Practice. - 2004. - № 77. - Vol. 1. - P. 101-119.

12. Joseph S. Growth following adversity: Theoretical perspectives and implications for clinical practice / S. Joseph, P. A. Linley // Clinical psychology review. - 2006. - № 26. - P. 1041-1053.

13. Joseph S. What Doesn't Kill Us: A guide to overcoming adversity and moving forward / S. Joseph. - Piatkus, 2013. - 336 p.

14. Levin, Peter A. Waking the Tiger-Healing Trauma. The Innate Capacity to Transform Overwhelming Experiences / Peter A. Levin with Ann Frederick. Berkeley, California: North Atlantic Books, 1997.

15. Lindstrom $C$. The relationship of core belief challenge, rumination, disclosure, and sociocultural elements to posttraumatic growth / C. Lindstrom, A. Cann, L. Calhoun, R. Tedeschi // Psychological Trauma: Theory, Research, Practice, and Policy. - 2013. - Vol. 5. - 1. - P. 50-55.

16. Milam J. Posttraumatic growth and HIV disease progression // Journal of Consulting and Clinical Psychology. - 2006. - Vol. 74. - № 5. P. 817-827.

17. O’Leary V.E., Alday C.S., Ickovics J.R. Models of life change and posttraumatic growth.// In R.G. Tedeschi, C.L. Park, \& L.G. Calhoun (Eds.), Posttraumatic growth: Positive changesin the aftermath of crisis Mahwah, NJ: Lawrence Erlbaum Associates, Publishers, 1996. - P. 1-22.

18. Park C.L. Religious and nonreligious coping with the death of a friend / C.L. Park, L.H. Cohen // Cognitive Therapy and Research. 1993. - № 17. - P. 561-577.

19. Park C. L. Assessment and prediction of stress related growth / C.L. Park, H.C. Lawrence, R. L. Murch // Journal of personality. - 1996. № 64. - Vol. 1. - P. 71-105.

20. Solomon Z. Positive and negative changes in the lives of Israeli former risoners of war / Z. Solomon, M. A. Waysman, Y. Neria, A. Ohry, J. Schwarzwald, M. Wiener// Journal of Social and Clinical Psychology. 1999. - № 18. - Vol. 4. - P. 419-435.

21. Speed N. Posttraumatic stress disorder as a consequence of the prisoner of warexperience / N. Speed, B. E. Engdahl, J. Schwartz, R.E. Eberly // Journal of Nervous and Mental Disease. - 1989. - № 177. P. 147-153. 
22. Tedeschi, R.G., Calhoun, L.G. (1996). The posttraumatic growth inventory: Measuring the positive legacy of trauma. Journal of Traumatic Stress, 9, 455-471

23. Tedeschi R.G. Posttraumatic Growth: conceptual foundations and empirical evidence / R.G. Tedeschi, L.G. Calhoun // Psychological Inquairy. - 2004. - Vol. 15 (1). - P. 1-18.

24. Janoff-Bulman R. Assumptive worlds and the stress of traumatic events: Applications of the schema construct / R. Janoff-Bulman // Social Cognition. - 1989. - Vol. 7. - P. 113-136.

25.Zoellner, T. \& Maercker, A. Posttraumatic growth in clinical psychology: A critical reviewand introduction of a two component model // Clinical Psychology Review. - 2006. -26 (5). - P. 626-653.

26. Брієр Д. Основи травмофокусованої психотерапії / Д. Брієр, К. Скот / Наук. ред. Вікторія Горбунова, Віталій Климчук. - Львів: Свічадо, 2015. - 448 с.

27. Горбунова В.В. Сприяння соціального оточення відновленню та зростанню осо-бистості при посттравматичних станах та розладах // «Наука і освіта» - 2016 - № 5 - С. 40-45.

28. Дорожевец А.Н., Соколова Е.Т. Исследования образа физического Я: некоторые результаты и размышления // В сб.: Телесность человека: междисциплинарные исследования (под ред. В.В. Николаевой, П.Д. Тищенко) - М., ИФАН, 1991, С. 67-70.

29. Дорожевец А.Н. Когнитивные механизмы адаптации к кризисным событиям //Журнал практического психолога, 1998, N4 C. $3-16$.

30. Зубовський Д. С. Феномен посттравматичного зростання як перспективний напрямок досліджень у вітчизняній психології // Проблеми екстремальної та кризової психології. - 2016. - Вип. 20 С. 63-74.

31. Климчук В. Посттравматичне зростання та як можна йому сприяти у психотерапії // «Наука і освіта», № 5, 2016, С. 46-52. 2007.

32. Левин П. Пробуждение тигра - исцеление травмы. - АСТ,

33. Огієнко В. Посттравматичний стресовий синдром i колективна травма в особистих наративах свідків Голодомору // Україна модерна, 2018 // Режим доступу: http://uamoderna.com/md/ ogienko-holodomor-trauma 
34. Осьодло В.І., Зубовський Д.С. Посттравматичне зростання особистості учасників бойових дій: сучасний стан та перспективи // Ukrainian psychological journal. - 2017. - № 1 (3). - C. 63-79.

35. Приходько I. I. Посттравматичне зростання як компонент емпіричної трансформаційної моделі психологічної безпеки особистості фахівця екстремального виду діяльності // Вісник Національного університету оборони України - 2013. - № 1 (32) - С. 269-273.

36. Романчук О. Психотравма та спричинені нею розлади: прояви, наслідки й сучасні підходи до терапії // HейрoNeus. - 2012. - № 1. С. 30-37.

37. Чачко С.Л. Пережить Холокост / С.Л. Чачко // Альманах науч. статей. - 2006. - № 5. - С. 26-34.

38. Чачко С. Л. Проблема посттравматического роста: попытка теоретического анализа / С.Л. Чачко // Вісник Одеського національного університету ім. І.І. Мечникова. - 2010. - № 15. - випуск 11. C. $140-148$.

39. Шелюг О.А. Багатовимірність феномену посттравматичного росту: біологічний, психологічний та соціокультурний складники особистісних трансформацій / О.А. Шелюг // Психологія і особистість. 2014. № 1. - C. 112-129.

\section{Information about the author:} Kostiuk O. I. PhD (Psychology), Senior Lecturer at the Pedagogy, Psychology, Medical and Pharmaceutical Law Department of the P.L. Shupyk National Medical Academy of Postgraduate Education 2/4, Glazunova str., Kyiv, Ukraine; Psychiatrist at the Center of Psycho-Social Rehabilitation of the National University "Kyiv Mohyla Academy" 


\section{COGNITIVE POTENTIAL OF METAPHORIZATION IN PERCEPTION OF "I-IMAGE"}

\section{Kostyuchenko O. V.}

\section{INTRODUCTION}

The perception of personal self and development of an individual's self-esteem is a necessary prerequisite for a successful life and professional self-realization. It is also crucial in communication and interaction, and information of a personal life position. "I-concept" is the manifestation of self-consciousness or a dynamic system of conceptions about himself which are used in a variety of meanings ("self-consciousness", "self-knowledge", "self-understanding", "self", "attitude to self", "self-esteem", "I-image", "self-awareness", "perception of I", "I-representation", "I-scheme", "I-mask", "I-conception", "I-system", "I-image", "identity", "ego", "self-image", etc.). The complexity and variety of the "I am" phenomenon are determined by its essence, meaning/content, structure and methods of study. As rightly noted by such scientists as I. Kon ${ }^{1}$ and V. Stolin ${ }^{2}$ that up to now the categorical status of the concept of "I am" remains insufficiently defined being one of the fundamental philosophical and psychological concepts.

R. Burns advises describing "I-image" only by the cognitive component of self-consciousness (descriptive) because it does not convey sufficiently the dynamic, evaluative, and emotional character of the individual's perception about himself ${ }^{3}$. "I-image" is a subjective reflection of the subject's objective state in a system of real-world relationships. In "I-images" is summarized the emotional and cognitive information about the essence of "I am" that the individual has isolated from subjective experience and actualized in a "new" activity. The need to perceive himself for the realization of his activity causes the individual to compare knowledge about himself with the planned activity forming the meanings

\footnotetext{
${ }^{1}$ Кон И.С. В поисках себя. Личность и ее самосознание. Москва: Изд. Политической литературы, 1984. 335 c.

${ }^{2}$ Столин В.В. Самосознание личности. Москва: МГУ, 1983. 286 с.

${ }^{3}$ Бернс Р. Развитие Я-концепции и воспитание: пер. с англ.; общ. ред. В.Я. Пилиповского. Москва: Прогресс, 1986. 422 c.
} 
of "I am". Perception of the integrity of personal existence, generalization and systematization of the knowledge about himself and the world create the basis for constructing the "I-concept" which includes not only "I-images" but also a system of ideas about perspective lines of development. Thus, the "I-concept" is a broader notion. It is the much more complete perception of the individual about himself than "I-image".

However, it should be stressed that "I-image" in contrast to selfconsciousness contains, along with perceived components, the unconscious "I am" at the level of well-being, and notions. The main function of "I-image" is to secure the integrity, wholeness of the individual, his essence to attain the subjective harmony. The contemporary psychological researches of diverse scholars (I. Kon, H. Kohut, C. Cooley, V. Merlin, J. Mead, D. Oshanin, F. Pataki, L. Pervin, H. Hartman, and others) stress the role of "I-image" as generalized mechanism of person's self-regulation in security of identification, personal responsibility, and creating a feeling of social involvement. Among the different forms of the "I-concept" processes are such as identification, inner dialogue, reflection, rationalization, attributing desirable qualities, appropriation of others' thoughts about himself, comparison, analysis of personal actions but we pay attention to the metaphorization.

The study of such a specific kind of cognitive activity as a metaphorization of "I-image" is relevant because it plays a special role in intellectual and creative personal development and in addition to that it is the least discussed in the researches of all cognitive processes in both domestic and foreign psychological science. The synthesis of theoretical data demonstrated that in-home psychological circles the most often the metaphorization is defined as a specific kind of cognitive activity that operates and controls the metaphorical images thus creating new images that are full of meaning and make meanings visible.

Recognition of metaphor as the multi-faceted phenomenon is founded in the works of K. Alekseev, V. Gak, J. Guilford, M. Johnson, D. Davidson, J. Lakoff, E. McCormack, V. Moskalyuk, S. Neretina, J. Ortega-and-Gasset, I. Polozova, O. Potebna, S. Sisoeva, V. Kharchenko, L. Shragina, R. Jakobson and others. The exposure of the "metaphorical image" category is related to the consideration of such notions as figurative code and image representations. 
The aim of this publication is to present a theoretical and empirical analysis of particularities of the cognitive function realization of such phenomena as the metaphorization in formation of "I-image" and its metaphorical representations.

\section{Metaphorical ground for formation of perceptual "I-image"}

The study of the particularities of the metaphorization as an independent type of the cognitive activities requires a discussion of the metaphorical image and particularly "I-image" as the main manifestation of its productive function of the reflection. The notion of an image (from English word "image") in psychology is one of the central categories for the very images reflect objective reality and thus they represent the meaning/content of the psychic of an object. The psychological dictionary defines the image as "a subjective picture of the world and its fragments that includes the subject himself, other people, environment, and time sequence of events"4. Thus, the image is one of the forms of objective reality reflection. However, it is not simply a mirror reflection but it is a creative reconstruction of an object. It is commonly accepted that the broad definition of the image is the representation of an object or event that exists in the mind since it is not only related to the visual images but also to the images that are formed through other modalities.

Thus, V. Zinchenko reckons that it is important to build a special space for more than ten imaginary languages ${ }^{5}$ which exist in European culture such as afterimages, i.e. traces of vivid images; images of dreams, hallucinations; synesthesia complex visual-tactile or visual-auditory images; reflected images and images generated images of fantasy, imagination, fairy tales, myths, science. In Indian culture, the number of types of visual images is more than thirty, and Europeans cannot translate their classification into their languages because they do not have the same perceptual experience, and even their linguistic equivalents do not exist in European languages.

A self-perception occupies a significant place in the structure of a holistic "I-image" of functional personality without the defense mechanism of personal expressions. The main need for functional personality is the creative self-realization of an adequately perceived reality. Apperceptive

\footnotetext{
${ }^{4}$ Психологический словарь; под ред. В.П. Зинченко, Б.Г. Мещерякова. 2-е изд. Москва: Астрель, Транзит книга, 2004. С. 240.

5 Зинченко В.П. Живое знание. Самара: Изд-во Самар. гос. пед. ун-та, 1998. Ч. 1. 248 с.
} 
ability to percept is an important condition for the formation of an adequate world-view position. It includes the realistic perceptions and conceptions of the following components of "I-image" such as physical (appearance, organism, practical skills, development of motor activity), mental (thoughts, feelings, desires, intentions, plans, ideals, interests), and the social self (social and moral qualities, ability to communicate, resolve conflicts, put yourself in the place of another, behave conscientiously, understand his rights and responsibilities, determine his status among the peers). An important aspect of A. Roche's concept of personal growth ${ }^{6}$ is the inclusion of such structural components of the personality as self (essence), "I am", body and conscience, plus the additional component like susceptibility. In the context of our study, it is important to consider "I-image." It is the most influential aspect of the cognitive component of the I-concept. The main characteristic of "I-image" is the individual's ideas of himself that usually seem to him authentic regardless of their objectivity. Many researches of scientists are devoted to the problems of "I-image" of a person (I. Kon, V. Stolin, E. Sokolova, S. Konkov, V. Mogun, Prescott Lecky). In its most general form "I-image" is the self, that is, the integral wholeness, the "singleness", the "reality" of the individual, his identity to himself. On that basis, a person distinguishes himself in the external world and among other people. The individual "I am" that includes biological, physical, physiological and psychological "I am" differs from a social "I am". Having many characteristics, "I am" generally has three main dimensions: existing, the real "I am" (which a person sees himself at the moment); the desired, ideal "I am" (what kind of person I would like to see myself); presented, role (image) "I am" (how the person introduces himself to others). All three dimensions coexist in the individual ensuring his integrity and development.

An ontogenetic cycle of development of "I-image" has its dynamic and phased nature of maturation in which the process of perception becomes important. As a result of such activities, a person gains knowledge that "I exist" the concept about himself, understanding of his place in life. Secondly, the development of "I-image" is caused by piling up of a diverse information about himself which establishes the status-role position of each intelligent representative of human beings, and secures forming of his first self-appraisal opinions, and consequently, on the basis

\footnotetext{
${ }^{6}$ Реан А.А. Акмеология личности. Психологический журнал. 2000. Т. 21. № 3. С. 88-95.
} 
of them informational synthesis of different "I am" in a certain schema occurs. On the one hand, all this happens through the cognitive format, namely, through the flow of the processes of perception (for example, reflection of the addressing of others to "me"), memory (remembering different reactions of the community, the estimates of the neighborhoods), and the first logical forms of thinking (the tendency to evaluate himself as others do). On the other hand, all this happens during the emotional reflection of reality. In other words, the development of "I-image" of the subject of cognition depends not only on ideas, attitudes, approaches, mastery of information and knowledge but also on the process of formation of his new cognitive-emotional psychoforms. This process causes a construction of a picture of I am (synonym of "I-image") ". "I-image" is a result of inter-subject, dialogical ("I am" - "You are" - "We are") interaction of people in the community, and "I-image" impacts on the building of the personal life position.

R. Assagoli's conceptual system ${ }^{8}$ is based on the assumption that a person is in a continual process of growth actualizing his undiscovered potential of a system of sub-personalities that are different from the subpersonalities of others. One of the goals of self-perception and selfobservation is to better understand the nature of himself and to enhance his ability to resolve the conflicts between sub-personalities. Every subpersonality reflects the needs of the whole personality for it are the part that performs certain important functions. When we perceive the world and ourselves we identify ourselves with one or the other sub-personality.

The person consolidates his personal life experience and predicting the future in mini-theories plus in the form of systems-values and meanings, which regulate the perception and conception of a person, determine the interpretation of the surrounding world and the actions of the subject in it. A person wants to make his theory coherent, mutually cohesive so that it would make the world predictable and understandable. Only the subject himself can evaluate his individual "theory" making it more realistic. He can re-examine the difficulties with which he has faced as a part of life, and being transformed he can learn how to solve them. In the mind of the subject environmental conditions are mediated,

\footnotetext{
7 Гуменюк О. Структурно-функціональне взаємодоповнення складових Я-концепції людини. Соиіальна психологія. 2005. № 5 (13). С. 66-75.

8 Асаджоли Р. Психосинтез: Принципы и техники = Psychosynthes: A manual of principles and techniques. Москва: Эксмо, 2002. 416 с.
} 
transformed through his system of life meanings, values, and ideals, norms and rules adopted by him. It can be said that the social-psychological space is a "subjective environment", i.e., an environment that is presented in consciousness, mastered and supplemented, or more precisely: "born", created, formed by the subject in accordance with his life principles, values, and goals.

The attention should be paid to such models of the world that are the basis for "I-image." 1 . The positive qualities of the World and "Actually me" are prevailed. For example, the world is "benevolent, secure, sensitive to my needs, reliable." I am "significant, needed, worthy of attention, love, and support." 2. The negative qualities of the World and "Actually me" are prevailed and I am the same as the others (cognitive-behavioral theory of helplessness by M. Seligman). The behavior of a person is passive and non-adaptive. 3. The level of perception and stereotyping is highly generalized when an individual perceives himself and others as being alike. 4. In the perception of him and others, the differentiation and separation are intensified. Also, a reflection is heightened, and anxiety is growing. I am not like the others, you are you, and I am I (F. Perls). Subjectivism is prevailed when the world, which is shared by all living subjects, is replaced by many "small worlds." I am the Universe to myself, I see reality solely from my point of view, and I am immensely lonely because no one can share with me my world. All other reality is being refracted through my unique self, so it is hard to say that there is anything objective. 5. Internal/External Determination (V. Frankl) or Determined Influence on the World, on Others, and the World and Others on Self. It is a perception of himself as one who determines his life in the world. It is an awareness of his capabilities and the external factors, and circumstances that may affect these opportunities. 6. The essential bond, the unity of a person and the world. It is a perception of himself as a part of the world and at the same time reflecting in himself the whole world, thus, experiencing his involvement in the existence of the world. This is an existential aspect of the model of the world (R. May, I. Yalom, A. Maslow). It is known as objectivism or philosophical concept. According to that view, we all can and should find common ground on the questions concerning the quality of reality and our place in it. It holds that those who defend their special positions are mistaken, and fall into illusion (G. Hegel, K. Marx). 
The main mechanisms for detecting the "meaningful oppositions" of the world perceived by a person are the following: metaphor that allows to make "familiar as unusual", allegory that permits "to match unmatchable" and "compare incomparable", analogy that allows to make "unusual familiar", and catachresis that enables to insert new content into old words and concepts. Linguistic semantics fills the entire subject world of man and is manifested in the language (metaphorical language), thinking (metaphorical thinking), and activity for heuristic metaphor directs the thought of man to search for the new ways of action. "Dialogue of metaphors" in the mind of a person allows reconstructing his inner world: to adapt to the objective environment by transforming the inner subjective world of personality (an individual changes his attitude to the objects), or to harmonize the inner world with the external by transforming the milieu when a person changes his behavior'.

In the process of self-realization (in Jungian terms - individualization) a person deliberately finds and restores the relationship with Self, with the unconscious psychic through words, and with the unconscious/nonconscious to absolute understanding through images and symbols ${ }^{10}$. Thus, the more complete and stable ego-identity is formed as a result of such a process that the main role is not to promote the realization of itself but to assist in the realization of Self. However, the restoration process of the relationship between Ego-consciousness and unconscious Self is not so simple for they communicate on the deferent vernaculars. The consciousness manifests itself in specific knowledge to enter into the situation of understanding. Thus, the person must master the symbolic language of the unconscious and learn how to decipher it for consciousness. One of the tools for such penetration into the unconscious may be the interpretation of the inner person's experience into the text of a metaphor, which unites a word and an image and allows not only to dive into the inner personal world but also to go back to the external world. The metaphorization of the inner experience of "I-image" helps to solve a specific problem, taking up the image of this problem, which permits a person to be dissociated from it for a while. Moreover, due to the metaphor, the private meaning of the problem is expressed in the common sense of the

\footnotetext{
9 Залевская А.А. Общенаучная метафора «живое знание» и проблема значения слова. Вестник Тверского государственного университета. Серия «Филология». 2007. № 12 [40]. Вып. 7 «Лингвистика и межкультурная коммуникация». С. 18-33.

${ }^{10}$ Франц М.-Л. фон. Психотерапия. Москва: Клуб Касталия, 2016. 250 с.
} 
person's life. There are certain rules of so-called therapeutic metaphors for the cognitive activation of metaphorical thinking (D. Gordon) ${ }^{11}$, they are to be identical to the problem but they should not relate to it directly. They are used for diving into the metaphorical world and identification of himself with personages and events of the imagery world. Such metaphors should offer a substitute for the experience, namely, some kind of model, which has to be heard and to go through the filters of personal problems and allows seeing the possibilities of a new choice. They have to have a positive completion as a reward for all troubles and trials, and to inspire, to improve mood, and to assist in finding a psychological resource. Thus, we believe that the metaphorization of inner experience is one of the effective ways of helping to solve psychological problems in the formation of "I-image", and the organization of individual personality development.

The basic initial tenets are important since the study of an image is hinged on them, and particularly with regard to metaphorical image which is a holistic, integral reflection of the reality, which simultaneously presents the basic perceptual categories (space, time, movement, color, shape, texture, etc.), and the most important function of it is the regulation of the activity for which this reflection must be objectively correct ${ }^{12}$. In addition to that, the image is a reflection of objective reality and at the same time an important link in the system of regulation of human actions. However, in spite of the fact that it is an object imagery it is also a subjective in form (it cannot be alienated, separated from the individual); it always has a prototype (initial data); its formation is an active process of exhaustive use of information from the surrounding reality in which a person exists; the content is continuously enriched, refined and corrected; that systemic formation is characterized by multidimensionality and multilayered ${ }^{13}$; it has a holistic character that provides a synthesis of a sensual image from a chaotic set of feelings; it does not consist of the images of the separated phenomena and objects but from the beginning develops and functions as a whole ${ }^{14}$; it is formed on the basis of data of all sensory

\footnotetext{
11 Гордон Д. Терапевтические метафоры. Оказание помощи другим посредством зеркала. СанктПетербург: Белый кролик, 1995. 196 с.

12 Зинченко В.П. О микроструктурном методе исследования познавательной деятельности. Эргономика: Труды ВНИИТЭ. 1972. Вып. 3. С. 77.

13 Завалова Н.Д., Ломов Б.Ф., Пономаренко В.А. Образ в системе психической регуляции деятельности. Москва: Наука, 1986, 173 с.

14 Смирнов С.Д. Образ мира как исходный пункт и результат любого познавательного процесса. Психология образа: Проблема активности психического отражения. Москва, 1985. С. 144.
} 
modalities, and in the most forms of figurative reflections the main role belongs to the visual modality (that is visualization of the image); it includes actual and potential, conscious and non-conscious components; it has a hierarchical structure that captures the most important characteristics of reality as well as the associations and relations between them ${ }^{15}$; it performs a prognostic function, which is one of the main functions; it is a system of personal expectations, and it predicts the aftereffect of personal actions; it has the sign and symbolic character. As a result of the symbolization process, it is possible to overcome the material subject's specifics of the objective world phenomena.

Psychologists mainly limit the scope of the study of metaphorical images by focusing on the cognitive processes because they recognize the huge information capacity of metaphorical images. At the same time, in modern psychology, the notion of the image is used not only in a narrowly cognitive sense. A. Paivi's studies made possible to reach a theoretical conclusion about the form of representation of information in memory, i.e., to the hypothesis of dual-coding based on the assumption that there are two coding systems and two ways of processing information in memory, namely, non-verbal image process, and verbal symbolic processes. Also such researchers as G. Bower ${ }^{16}$, M. Gazzaniga and R. Sperry ${ }^{17}$, D. Kimura $^{18}$, B. Milner ${ }^{19}$ investigate the associative role of images. The well-known national neuropsychologist $O$. Luria studied that topic as well. ${ }^{20}$ It should be noted that in accordance with the conceptualpropositional model of J. Anderson, G. Bower ${ }^{21}$, and Z. Pylyshin ${ }^{22}$ both visual and verbal information are presented in the form of verbal statements about objects and their relationships.

It was started by such scientists as V. Ganzen, O. Gostev, L. Itelson, B. Petukhov, V. Rubakhin, A. Saboshchuk, V. Tyukhtin, and others who attempted to systematize the images on the basis of the time phases of the

\footnotetext{
15 Баксанский О.Е., Кучер Е.Н. Современный когнитивный подход к категории «образ мира» (методологический аспект). Вопросы философии. 2002. № 8. С. 66.

${ }^{16}$ Bower G.N. Mental imagery and associative learning. In L.W. Gregg (Ed.): Cognition in learning and memory. New York: Willey, 1972. P. 51-88.

${ }_{17}^{17}$ Андерсон Дж. Когнитивная психология. 5-е изд. Санкт-Петербург: Питер, 2002. 496 с.

${ }^{18}$ Солсо Р.Л. Когнитивная психология: пер. с англ. Москва: Тривола, 1996. 600 с.

${ }^{19}$ Milner B. Disorders in learning and memory after temporal lobe lesions in man. Clinical Neurosurgery, 1972. Р. 421-446.

20 Лурия А.Р. Язык и сознание. Под редакцией Е.Д. Хомской. Изд-во Моск. ун-та, 1979, 320 с.

${ }^{21}$ Anderson J.R., Bover, G.H. Recognition and retrieval processes in free recall. Psychological Review, 1972. P. 97-123.

${ }^{22}$ Pylyshin Z.W. The «causal power» of machines. Behavioral and Brain Sciences, 3, 1980. P. $442-444$.
} 
conscious mental state as a reflection on the images of the time category using such characteristics like liveliness, brightness, controllability ${ }^{23}$ taking into consideration the objective reality and activity of the subject in the process of image formation ${ }^{24}$ and remembering the principles of a harmonious whole, based on the signs of similarity, and affinity of essential features ${ }^{25}$.

V. Zinchenko considers the "image" as a regulator of human activity and as its product and explains the mechanisms of its creation through the formation of a visual image "by overcoming the redundant and inadequate variants", and noting that the materiality does not coincide with imagery, integrity, concreteness ${ }^{26}$.

Due to their inherent specificity, metaphorical images can perform the following functions: cognitive, prognostic, regulatory, creative, and communicative. Consider the specifics of each function. Thus, the cognitive function of the metaphorical image in its visibility is to effectively reflect and to render "visible" embodying in space-time structure and transforming into dynamic models virtually any categorical relations of reality such as space-time, attributive, causal, teleological, existential, and others (by B. Itelson). As a rule, the image is considered as a medium and in connection with that its epistemological function is explored. First of all, the studies focus on the role of images in visual perception, figurative memory, figurative thinking, imagination, and feelings. The reproductive nature of these processes and the identification of their main features were revealed in experimental and theoretical studies by B. Ananiev, S. Krakov, O. Leontiev, S. Rubinstein, A. Smirnov ${ }^{27}$. Since the images are multidimensional, multi-categorical, and also polymodal so in them, not only the fundamental perceptive categories are reflected but also the relationships between them, both within one category, and intermodal relations. Metaphorical images are characterized by subjective simultaneity which allows a person to instantly "grasp" the relationship between the elements of a real or imagined situation. Simultaneity

\footnotetext{
${ }^{23}$ Гостев А.А. Образная сфера личности. Психологический журнал. Т. 8. 1987. № 3. С. 33-42.

${ }^{24}$ Гостев А.А., Рубахин В.Ф. Классификация образных явлений в свете системного подхода. Bonpocbl психологии. 1984. № 1. С. 33-43.

${ }^{25}$ Ганзен В.А., Гостев А.А. Систематика мысленных образов. Психол. журнал. Т. 10. 1989. № 2. C. $23-37$.

26 Зинченко В.П. Живое знание. Самара: Изд-во Самар. гос. пед. ун-та, 1998. Ч. 1. 248 с.

27 Завалова Н.Д., Ломов Б.Ф., Пономаренко В.А. Образ в системе психической регуляции деятельности. АН СССР, Институт психологии. Москва: Наука, 1986. 174 с.
} 
characterizes not only the perception of real objects but also imaginary objects including coded objects ${ }^{28}$.

The regulation of behavior and activity occurs due to the intentional and affective components of the image when a certain degree of independence of activity from the immediate external situation is allowed. One of the main functions of metaphorical image is the function of regulation of relations with the material world, and this function is realized through the regulation of both the simplest actions and the most complex forms of activity, and in particular, through the regulation of executive acts that are carried out in the external world, since it is in the images such as moving, perceptive, mnemonic, imaginary recorded the results of these acts. This is possible because the image is a certain subjective reality that is always objectified and exteriorized (localized) in the outer threedimensional space, i.e., where the objects are located or actions with them are performed. ${ }^{29}$ The founders of the theory of subjective behaviorism, namely, G. Miller, E. Galanter, K. Pribram paid serious attention to the analysis of the influence of images on human behavior. They defined the image as the accumulated and organized knowledge of the human being about himself and about the world in which he exists. The image included everything that the human being has acquired - his values and his facts. Behavior function regulation is realized due to the presence in metaphorical images operative components as well as the corresponding motivational and goal aspects of the activity. Moreover, external circumstances are taken into account. Thus, these processes allow the images to be transformed into perceptive-motor schemata.

The communicative function of the metaphorical image is based on a certain informative nature of the metaphorical image for it is capable to act as a carrier of information between communicators, and to complete linguistic communication in the conditions of impossibility or insufficiency of verbal ways and means in transmitting information from one subject to another.

Such abilities as to "see the essence of things", to keep "the unity of the views (a vision)" and for "understanding" are enhanced with the

\footnotetext{
28 Зинченко В.П. Психологические основы педагогики. Москва: Гардарики, 2002. 431 с.;

Зинченко Т.П. Память в экспериментальной и когнитивной психологии. Санкт-Петербург: Питер, 2002. $320 \mathrm{c}$.

29 Зинченко В.П. Психологические основы педагогики. Москва: Гардарики, 2002. С. 216.
} 
growth of the overall culture ${ }^{30}$, in which the simultaneity being a characteristic of the metaphorical image plays an important role for it opens a horizon for receiving more information than through discrete way.

According to our view, the creative function is one of the main functions of the metaphorical image that presupposes the presence of elements of creativity in its creation ${ }^{31}$. In the writings of R. Arnheim and $\mathrm{V}$. Zinchenko ${ }^{32}$ the connection of perception with the processes of creativity in different fields of human activity is stressed where the visibility of the metaphorical image belongs not to the sphere of the object reproduction in its pure form but the sphere of reconstruction and construction (modeling, modification, transformation) of the object. Owing to the creativity of metaphorical images, it becomes possible to obtain information on the structural-spatial and temporal characteristics of possible worlds by a visual-metaphorical transformation of the unknown into the known, the known into the unknown, and a part into a whole. Thus, an individual picture of the world is created in the visual images. The creativity of metaphorical thinking assumes that the same object, the same subject situation, the reality, and actual or sought integrity can be a prototype of a huge number of different models or modeling ideas.

We hold that the need for the study of the metaphorical systems from the social aspect of the world perception is obvious since it enables to unfold in fullness the capacities of human individuality, his multi-faceted and creative potential.

\section{Metaphor as an effective tool for awareness of the "I-image"}

Let us pay attention to the definitions of such concepts as "metaphor", "metaphoricity", "metaphorization". The metaphoricity is determined as a willingness to work in a fantastic, "impossible" context, a tendency to use symbolic, associative means to express one's thoughts ${ }^{33}$. One of the processes of appearance and representation of the mental models in the

\footnotetext{
30 Зинченко В.П. Психологические основы педагогики. Москва: Гардарики, 2002. 431 с.

31 Зинченко В.П. Развитие зрения в контексте перспектив общего духовного развития человека. Вопросы психологии. 1988. № 6. С. 15-29.

32 Арнхейм Р. Визуальное мышление. Зрительные образы: феноменология и эксперимент. Душанбе: Тадж. гос. ун-т, 1971. Ч. 1. С. 9-17, С. 3-31.; Ч. 2. С. 8-98; Ч. 3. С. 6-79.

Арнхейм Р. Искусство и визуальное восприятие: пер. с англ. Москва: Архитектура-С, 2007. 392 с.

Арнхейм Р. Новые очерки по психологии искусства: пер. с нем. Москва: Прометей. 1994. 352 с.

Зинченко В.П. Миры сознания и структура сознания. Вопросы психологии. 1991. № 2. С. 15-36.

Зинченко В.П. Психологические основы педагогики. Москва: Гардарики, 2002. 431 с.

${ }^{33}$ Йоас Х. Креативность действия: пер. с нем. Санкт-Петербург: Алетейя, 2005. 320 с.
} 
language is metaphorization. This is a fast-moving process that leads to a dynamic state of knowledge about the world because the associative imagination which is caused by formed meaning participates in this process at the same time and incompatible linguistic materiality which demonstrates the cognitive function of the metaphor at first sight. The metaphorization is based on the indistinctness of concepts which are operated by a person reflecting a variety of extracurricular activities in one's mind. In the metaphorical everyday consciousness, choosing the standard "everything fits all" like a single holistic image is created of the integral reality in which "everything consists of all"34. A specific concept is used to express the abstract, the empirical concept is used for the symbolic but the system of sensual cognition replaces another idea, etc.

Each person understands metaphors in his way which causes a certain ability of complex ones. There is a sense of individual purpose in the subconscious. Metaphorical stories are hardly straightforward and they let to choose the right definition. To understand the metaphor means to trace a path of its creation. However, many factors are involved in the creation of the metaphor which makes the metaphorization an individual creative process. The author's personality is a leading factor in creating the metaphor considering his age, gender, and lifestyle. First and foremost, the process of the metaphorization involves a motive for choosing a particular expression depending on the pragmatic intent and the profound interest of the subject in the pragmatic interest of a subject and a subject area. The concept is also influenced by the subject area that the author "thinks" creating the associative complex: encyclopedic, national-cultural knowledge or his imagination as well as a "linguistic sense" 35 . Metaphorical abilities are a set of properties of the mental system, which are shown in the implementation of functions performed by the metaphor. The individual expression of metaphorical abilities has different levels especially of young people: the ability to make up is constructed independently metaphors; to interpret complex metaphors such as fables, parables, etc.; to use well known metaphorical expressions depending on a situation $^{36}$.

\footnotetext{
${ }^{34}$ Шрагіна Л.І. Технологія розвитку креативності. Київ:Шкільний світ, 2010. С. 53.

35 Терещук А.Д. Креативність як невід’ємний компонент інтелектуального розвитку особистості. Людина у світі духовної культури. Київ, 2002. Ч. 2. С. 43-44.

${ }^{36}$ МакКормак Э. Когнитивная теория метафоры. Теория метафоры: пер. с англ., фр., нем., исп., пол. под. ред. Н.Д. Арутюновой и М. А. Журинской. Москва: Прогресс, 1990. С. 358-387.
} 
Any metaphor is based on a concept that is understood as a deep meaning and a collapsed semantic unit from a meaningful point of view. Creating metaphors, the properties of an object which is the referent of comprehension and some features which are associated with the sensual image of reality logically interact. This name of the reality is used in a specific problem-nominative situation, namely, the formation of a new concept and its verbalization. Each content of a particular text is constructed depending on the personal subsystem of concepts ${ }^{37}$.

All varieties of forms of the metaphors by nature seek to scrub round any conscious blockage or resistance to penetrate the level of the subconscious. It is the subconscious that responds to the riddle of metaphor to find some individual solution that corresponds to the experiences and needs of a particular listener ${ }^{38}$.

The metaphor has come to be understood as the key to understanding the foundations of thought and the processes of creation of the world and its universal image. A man does not discover similarity so much as he creates it. As logic has become dominant as a form of human thinking, the metaphor began to play the role of a mechanism that made it possible to combine what is considered incompatible. The world of a person is represented by the objective world which is the world of material objects and the subjective world which is the world of "ideal objects" (feelings, thoughts, and ideas). There would be no vocabulary of the "invisible worlds", the inner life of a man, without the metaphor. There is always a problem of marking and revealing the content talking about the ideal. It is possible to tell about the unknown only by comparing it with something known or familiar. The problem is a contradiction. An ideal object should be material to be perceived and displayed in one's mind but it cannot be material because it is a mental process 39 .

At present, the growth of the interest in the metaphor is related to "a change in the scientific paradigm of humanitarian knowledge. The activity of a person that provides the orientation in the world, his practical acquisition, cognition, and understanding of the processes taking place in

\footnotetext{
${ }^{37}$ Гак В.Г. Метафора: универсальное и специфическое. Метафора в языке и тексте. Москва, 1988. C. 99.

${ }^{38}$ Артемова О. І. Креативність як засіб розвитку мовлення учнів. Еврика. № 1., 1998. С. 60.

39 Лакофф Дж., Джонсон М. Метафоры, которыми мы живем. Теория метафоры: пер. с англ., фр., нем., исп., пол. под. ред. Н.Д. Арутюновой и М.А. Журинской. Москва: Прогресс, 1990. С. 397.
} 
the external and internal world is in the center of this knowledge" ${ }^{\prime 40}$. In the current psycholinguistics, the metaphor was understood, above all, as a cognitive phenomenon, a powerful tool of thought, a fundamental method of knowing, conceptualizing reality, and "a specific thinking process in which we understand a sphere of experience in concepts of another sphere",41.

Therefore, it is no accident that the metaphor is seen as a key to understanding the foundations of thinking and the processes of creating not only a national-linguistic view of life but also its universal image. The cognitive theory of conceptual metaphor is the most popular among the many theories of the metaphor ${ }^{42}$. The cognitive explanation of a metaphor is given by its anthropometricity. A linguistic metaphor, the creation of which is created spontaneously in thinking, is based on the ability of a person to grasp and form associative connections between concepts ${ }^{43}$. According to this theory, the metaphor is a cognitive operation of concepts and means of conceptualization. This allows us to comprehend a particular area of reality in terms of conceptual structures that are originally formed based on experience gained in other areas. As Lakoff notes, "the metaphor permeates our daily lives and it showed not only in language but in thinking and actions that facilitate the thought process. It gives us an empirical framework within which we can master the abstract concepts we receive. Our everyday conceptual system within which we think and act is metaphorical". ${ }^{44}$ E. Jordan considers the metaphor "a verbal formulation of reality that is embedded in diversity, perceived as a complex set of properties;... the affirmation of individuality by which the set of real qualities becomes an individual or asserts as reality" ${ }^{\text {" }}$.

Thus, the cognitive metaphor can be defined as one form of conceptualization that involves one entity through another in the most general approach. By its nature, the metaphor is not a linguistic but

\footnotetext{
${ }^{40}$ Мазепова О.В. Метафора як засіб створення мовної картини світу. Мовні і концептуальні картини cвimy. Київ, 2004. Книга 2, № 12. С. 3.

41 Телия В.Н. Метафоризация и ее роль в создании языковой картины мира. Роль человеческого фактора в языке. Язык и картина мира. Москва, 1988. С. 317.

42 Лакофф Дж., Джонсон М. Метафоры, которыми мы живем. Язык и моделирование социиального взаимодействия Москва, 1987. С. 126-172.

${ }^{43}$ Селіванова О.О. Актуальні напрями сучасної лінгвістики (аналітичний огляд). Київ, 1999. С. 81.

${ }^{44}$ Lakoff G. Women, Fire and Dangerous Things. What categories reveal about mind. Chicago; L.: University of Chicago Press, 1987. P. 12.

${ }^{45}$ Jordan E. Essays in Criticism. Univ. Chicago Press, 1952, p. 113, 117, 124.
} 
conceptual phenomenon ${ }^{46}$. Thus, the metaphor is one of the main means of knowing the objects of reality, naming them, creating images and creating new meanings, which perform nominative, cognitive, artistic and semantic functions ${ }^{47}$. The metaphor is based on the semantic and conceptual knowledge of a person, the knowledge about the outside world, categorical, and social knowledge.

\section{The empirical study of the value-semantic component of the metaphorical "I-image"}

The personal identity is what a person considers deep in mind answering the question "Who am I?" This is an internal agreement with a personal and social role that conduces the internal consistency of the content of his external manifestations (personal actions), adapts "I am" to the environment to meet the basic necessity to be accepted and recognized. Most respondents are fully aware of their identity but some do not have the holistic "I-image". A productive way of realizing one's identity is popular among psychologists, coaches, psychotherapists, and educators. This is a work with personal metaphors and metaphorical ways of realizing oneself. It is quite obvious that one or another personal metaphor is connected and determined by oneself, its vital values and personal roles.

The empirical study involved students of second, fourth, and fifth-year (total of 246 persons at ages 18-45 years) of the Kyiv University of Culture and the Kyiv National University of Culture and Arts. The preference of a student audience is explained by the fact that the formation of language abilities is almost complete in most, the vocabulary remains relatively stable, and there is the hierarchical structure of values. A characteristic of the development of students' personalities is the development, ordering, integration of the worldview, public life, the past, and the future, morality, science, art, a man, and the reason for being. At the same time, students' educational activity depends largely on some individual traits that are of great importance for making independent decisions. Life values, level of subjective control, personal accentuations, and self-esteem concerning the world views play an important role in the

\footnotetext{
46 Ченки А. Семантика в когнитивной лингвистике. Фундаментальные направления современной американской лингвистики. Москва: Изд-во МГУ, 1997. С. 355.

${ }^{47}$ Антонюк М.О. Метафора та її роль в мовній картині світу. Мовні і концептуальні картини світу. Київ, 2002. № 7. С. 15.
} 
learning process. Thus, the problem of choosing values of life, selfdetermination, identity formation, and outlook arises during this period.

The usage of metaphorical images in a visual and verbal form provides an opportunity to understand the emotional, mental, and physical sphere psychological resources of the individual in a safe environment, which are free from evaluative judgments ${ }^{48}$.

The main part of our empirical study was the analysis of students' verbal production, obtained as a result of the task of the projective methodology based on the metaphor "Man-book" 49 The specified method as a method of mediating the study of personality is based on the creation of favorable conditions, a specific, plastic stimulating situation for the complex analytic-synthetic activity of the person, imbued with personal meaning, for trends, attitudes, emotional states, and other features of the personality. Students were asked to imagine that each of them is a book and to answer a set of questions in writing, including: "Which title (cover, image, beginning, genre, leading image) is most appropriate?" The first, third, and fifth answers were noted for analysis. The analysis of descriptions was conducted based on the distribution of statements by group and types of values in the system of "I image". The verbal presentation of oneself through the image "I am a book" can be considered as a source of symbolic information about its author as a projection of the person's image of the world, values, and subjective experiences. In the system "I am" images as the system of representations can be distinguished ideas about their characteristics, the complex of person's ideas about relationship with others, the idea of values in which the personality is formed, the person's idea about goals and ideals, and self-concept. The structural and functional analysis of personal values made it possible to distinguish the most common forms of their representation: value as intention, significance, positive significance and benefit, ideal, conscious sense, orientation and motive, purpose, value orientation. Among the system of terminal and instrumental values, we have found the dominance of cognitive value (16.4\% of students), "incipience and developing" $(7.8 \%)$, compared to the minimal manifestation of "self-confidence" $(2,05 \%)$, (See Table 1$)$.

\footnotetext{
${ }^{48}$ Костюченко О.В. Метафоризація як психологічний ресурс потенційності майбутнього фахівця. International Journal of Education And Science (IJES). Vol. 2. No. 2. $2019 . \quad$ C. 50-51 / DOI: $10.26697 /$ ijes.2019.2.35

${ }^{49}$ Кипнис М. Апельсиновый тренинг. Москва, 2008. 111 с.
} 
Table 1

The frequency distribution of personal values by students of different courses in the I-image "Man - Book"

\begin{tabular}{|l|c|c|c|c|}
\hline \multicolumn{1}{|c|}{ Individualization values } & $\begin{array}{c}\text { II } \\
\text { course }- \\
\mathbf{1 2 0}\end{array}$ & $\begin{array}{c}\text { IV } \\
\text { course - } \\
\mathbf{5 6}\end{array}$ & $\begin{array}{c}\mathbf{V} \\
\text { course - } \\
\mathbf{7 0}\end{array}$ & $\begin{array}{c}\text { Total - } \\
\mathbf{2 4 6}\end{array}$ \\
\hline Self-confidence & 0 & 0 & 7,14 & 2,05 \\
\hline Knowledge & 15,00 & 12,5 & 21,43 & 16,39 \\
\hline Creativity & 5,00 & 5,36 & 1,43 & 4,1 \\
\hline The beauty of nature and art & 2,50 & 3,57 & 2,86 & 2,87 \\
\hline $\begin{array}{l}\text { The formation and } \\
\text { development }\end{array}$ & 12,50 & 5,36 & 1,43 & 7,79 \\
\hline $\begin{array}{l}\text { The harmony with oneself } \\
\text { and the world }\end{array}$ & 3,33 & 5,36 & 2,86 & 3,85 \\
\hline Self-centrism & 7,50 & 3,57 & 0 & 4,51 \\
\hline The truth & 9,17 & 5,36 & 5,71 & 7,38 \\
\hline Romance, mystery & 5,00 & 1,79 & 1,43 & 3,28 \\
\hline
\end{tabular}

The received partial distribution data are based on Z. Karpenko's specified ontogenesis levels of subject's value-semantic consciousness. The samples of the students' metaphorical "I-images" described by the students are supplied:

1) relative subject (a person as an object of social impact, individual - 15\%)

Examples: "Get burned once, we close our secrets on the lock; a house that is by the sea; behind the iron door; books under a blanket on a rainy day, roller coasters; changeable sea, it may be calm or stormy; a city that is on the seashore, it is quite noisy and anxious, but it is possible to find a place and time for the rest of mind; dust in the rays of the sun that is raised by the crow's wing on a hot day; like a transparent air be enlightened; a glass flask; a ship that is indifferent weather conditions; like a long road with many obstacles that are overcome; striped zebra, unexpected, stormy; sand that requires wind in order to move it, and its movement is like an impetus to a certain direction; a balloon, I strive after the wind and try to use everything that gives me life; heating burner that is near the opened awning window that can be quenched; running over pitcher" etc.;

2) mono-subject (a person who is active doer, subject concerning individual activities $-28 \%$ ) 
Examples: "Are we spontaneous or the world around us?" "I - I am Self (I am tired from sleeping, I grow tired from reading, but primarily writing to you made me weary)", "I. I and... I and Self. I am not Self, Self, Self", "The autobiography of a stranger (I will not reveal only one...)", "Personal world (About thoughts in the life without a head. The value of his fabricated words)", "Anna Gerda (One Sunny Day...)", "Something spectacular of my life (How I came into this world. How I sought inspiration, my dreams and hopes, mysterious Encounter. And I knew happiness through unhappiness); My story (Now you will plunge into my world); The mystery of myself (My life, but what I have not done. Something that was not thought over. What may be changed?); labyrinth, where it is easy to get lost and it is difficult to get out, but if you find a way out - you won; the labyrinth where I look for the best way out for myself marveling at all what I meet round the corner; a fire that is to be kept burning; lens that collects light without distortion; pendulum motion is smooth and at the same time it is periodic and with the high frequency; it is like with candy, you never know which one you will get; is it a quiet river or is it a stormy river; a bird that soars in the air; transparent air that is imbued by the light; a small house located in a mountainous area that is washed by the sea or ocean, which tourists and indigenous people rarely visit, where it is not always favorable weather; like a bicycle that requires labor for movement, sometimes it has to be repaired and you further pedal your bicycle; the first ascent of Everest, you ascend more higher and it becomes more difficult but at the same time more interesting and striking, and the magnificent landscapes are opened, the self-confidence is increased, the goals are approaching; heart rate, heartbeat, every day rhythm; swing; complicated lace that is made by intensive labor; the water without which it is impossible but it can destroy much in its path; like an electrical wiring without insulation and the current strikes anyone who touches it; as a greenhouse effect so when I do good then it comes back to me; candy that has a beautiful pink color with different tastes which are nice or not delicious; like a dandelion on which some of its seeds are blown off by the wind and some remain, it is colorful but part of it is black and white", etc.;

3) polysubject (group interaction subject, personality - 18\%)

Examples: "Fight for a place under the sun, hurricane, ship, waves, fire, water; seasons; a bird or a tiger that has found its second half, the 
further existence of the two, and a collaborative learning of the world; beehive with bees: all actively trying to improve the current, life is in full swing around; "hodge-podge", there are many all kinds of different things, incompatible but they are together; pizza; it is a struggle for the life or an ants in an ant-hill that has no sense of self; it is a fountain of various sensations, meetings, events that are turbulent and instructive", and the like;

4) metasubject (subject of socially significant creative activity, personality $-32 \%$ )

Examples: "Unread Novel", "Rebellious Spirit", "a Search" (2), "A New Life as a Second Chance (It would seem that there is nothing to expect for, but a life granted to him a second chance"), "Chronicle of Growth and Aging, moment and eternity", "The special path", "The path to self"(2), "Alone with dreams", "Rose in darkness", "Create yourself. It is the beginning!" "... this story is about me...", "Self-perfection of man." "The man who perfected himself (This story might seem fictional if it did not happen. The beginning. The middle. Is it not the end is not it?)." "A Search. A Way, a direction." "The Life and History of a Global Person", "Acknowledgment to All Who Helped in My Formation as a Person", "Acquiring a Global Mindset" (Unusual acquaintances. Childhood), "It was a long time ago in a childhood... (Childhood. Fatherhood, Youth), "Painting in the sand", "a boiled foam in the calm ocean", "A Girl with flax-colored hair", "My life is like a song", "The life and work of an outstanding person", "Intuition as a lifestyle", "Intuition (It possibly has created many problems);" "Creativity is like a water"; clay; raisin pie, someone loves raisins, someone does not; children who constantly wonder for some reason and I do not want to lose that a childhood spirit; a smart book (a purpose and a content are different and the end is invented by everyone); set of nested dolls, you must open and go through the different periods of life to discover your true self; a tree that grows taller and taller with each step, and with the thickness of the trunk and the strength of the bark the experience is gained; a large strong tree with the most beautiful fruits that, when they are falling to the ground, give birth to a new life. This tree won't be destroyed by either wind, or drought, or flood, etc.;

5) absolute subject (subject of a spiritual practice, universality - 7\%)

Examples: "The truth of the depth, I bring up not your son but myself", "Mistake in the Head", "Never ask anyone", "More black than white", "Be persistent and honest with yourself and others", "Destiny", 
"Truth (from the description of the past days, and therefore questions arise)", "The life is... Man is a whole galaxy, and you judge them according to appearance", "I am a life", "The history of human development covers... (What has mankind found interesting and useful? Man creates life on the planet. An unmatched creature is a human being)", "To live is happiness! (We see the world not as it is but such as we are. My vision of the world... Rejoice)"; "The air at the top of the mountain after a long climb, the road to perfection, the Golden Age (there are no wars, people draw information from the universe, everyone has all that he needs, everyone loves and respect each other); a rainbow; a dance under the supervision of gracious God; a monk who comprehends some important thing, and must sit at the foot of a desert mountain until he reaches an enlightenment or realizes his mistake; deep ocean that is powerful, boundless, filled with life, its forms, mysteries, etc.).

The interpretation of metaphors allows us to penetrate the world of internal oppositions - various subjective confrontations within the integral subjectivity (dialogue of a relative subject (individual) with metasubject (individuality), polysubject (personality) with the absolute subject (universe), etc.). The interpretation result of metaphorical representations of value consciousness is, considered phenomenologically, the achieving of centering/intentionality of consciousness, namely, understanding of the manifest and hidden content of the metaphor, the grasp of "interacting voices", objectified in the word, gesture, intonation, etc., of the internal dialogue.

\section{CONCLUSIONS}

On the whole, the theoretical and empirical analysis of this problematic demonstrates that, since metaphor is a unified cognitive structure that combines mental representations with the sensory and empirical basis, conceptual projections are directed from the abstract sphere, which is not perceived by senses, namely, by the sphere of sensory, and specific perception. Therefore, the role of metaphor is the most significant in the reflection of those fragments of a reality that are not given to us in the immediate senses, in the formation of abstract concepts, and identification of the new realities. The process of creating new metaphors reflects the transformation in self-perception and self-image and makes it possible to see "I-image" in a new light. Yes, the image of "I am" 
is not a mirror image of the real "I am" but only an interpretation that depends on the prism through which self-perception and world-perception occur. The process of metaphorization can be such a prism providing an awareness of what is learned using already gained knowledge and stored with what is known, and fixed in the form of the linguistic unit's meaning. The study of a metaphor becomes a cognitive and communicative oriented. Thus, metaphorization contributes to the formation of the perceived holistic image of "I-Other-World", and creates the conditions for the awareness of himself as the human being. This is, in turn, a possibility for transferring activities to other situations. The perceived metaphorical "I-image" is a picture and a certain form of information. When it passed the "test" of conformity to the requirements of a problematic situation that it has a chance to be transformed into a thinking image. Moreover, it is a sign, a symbol, a code, more or less adequate guidelines in search of the direction of thinking, while remaining always subjective, because it always has a personal tinge. It is a projection that includes past experience, motivational sphere, values, interests, views, beliefs. In spite of all the variety of personality types metaphors have important features: the ability to act as a stabilizer of the psycho-emotional state of the person demonstrating models of effective analogous behavior, which is extremely important for a human being as a social creature; the ability to contribute to the transformation of the Personal History, and to release from harmful, ineffective life scenarios, and to create the new life scenarios, to open and realize the new opportunities in life.

Prospects for further research. The main task of future research is to study the universal and specific nature of metaphors including their perception and interpretation in the process of speech and building the formation model of the system of "I-Other-World" images by means of metaphorization.

\section{SUMMARY}

The article theoretically and empirically substantiates the cognitive potential of the metaphorization in the perception of "I-image" as a subjective reflection of the objective state of the subject in the system of real communication with the real world. "I-image" along with known components contains the unconscious "I am" at the level of self-perception and concepts. "I-image" realizes the main function - that is ensuring the 
comprehensiveness, the integrity of the individual, his essence to feel subjective harmony, and it is a necessary prerequisite for the formation of a person's life position, success in life and professional self-realization, communication, and interaction. It has been found that the metaphorization of the inner experience is one of the effective ways in the assistance of solving psychological problems in the formation of "I-image" and organization of individual development of a person as well as a productive way of personal identity perception when an individual uses personal metaphors. The emphasis is placed on the ability of personal metaphors to stabilize the psycho-emotional state demonstrating models of effective analogous behavior, and equally on the ability to transform the Personal History. The models of the world proposed by the different psychological theories are mentioned. "I-image" is based upon them. The features of the functional realization of metaphorical images are determined. The quantitative and qualitative analysis of students' metaphorical images of "I am" is performed. The students" metaphorical images of "I am" are developed in accordance with their value-semantic consciousness.

\section{REFERENCES}

1. Андерсон Дж. Когнитивная психология. 5-е изд. СанктПетербург: Питер, 2002. 496 с.

2. Антонюк М.О. Метафора та іiі роль в мовній картині світу. Мовні і конщептуальні картини світу. Київ, 2002. № 7. С. 15.

3. Арнхейм Р. Визуальное мышление. Зрительные образы: феноменология и эксперимент. Душанбе: Тадж. гос. ун-т, 1971. Ч. 1. С. 9-17, 3-31.; Ч. 2. С. 8-98; Ч. 3. С. 6-79.

4. Арнхейм Р. Искусство и визуальное восприятие: пер. с англ. Москва: Архитектура-С, 2007. 392 с.

5. Арнхейм Р. Новые очерки по психологии искусства: пер. с нем. Москва: Прометей. 1994. 352 с.

6. Артемова O.I. Креативність як засіб розвитку мовлення учнів. Еврика. № 1. 1998. С. 60.

7. Асаджоли Р. Психосинтез: Принципы и техники = Psychosynthes: A manual of principles and techniques. Москва: Эксмо, 2002. $416 \mathrm{c}$. 
8. Баксанский О.Е., Кучер Е.Н. Современный когнитивный подход к категории «образ мира» (методологический аспект). Вопросы философии. 2002. № 8. С. 66.

9. Бернс Р. Развитие Я-концепции и воспитание: пер. с англ.; общ. ред. В.Я. Пилиповского. Москва: Прогресс, 1986. 422 с.

10.Гак В. Г. Метафора: универсальное и специфическое. Метафора в языке и тексте. Москва, 1988. С. 99.

11. Ганзен В.А., Гостев А.А. Систематика мысленных образов. Психологический журнал. Т. 10. 1989. № 2. С. 23-37.

12.Гордон Д. Терапевтические метафоры. Оказание помощи другим посредством зеркала. Санкт-Петербург: Белый кролик, 1995. $196 \mathrm{c.}$

13. Гостев А.А. Образная сфера личности. Психологический журнал. Т. 8. 1987. № 3. С. 33-42.

14. Гостев А.А., Рубахин В.Ф. Классификация образных явлений в свете системного подхода. Вопросы психологии. 1984. № 1. С. 33-43.

15. Гуменюк О. Структурно-функціональне взаємодоповнення складових Я-концепції людини. Соціальна психологія. 2005. № 5(13). C. $66-75$.

16. Завалова Н.Д., Ломов Б.Ф., Пономаренко В.А. Образ в системе психической регуляции деятельности. Москва: Наука, 1986, $174 \mathrm{c}$.

17. Залевская А.А. Общенаучная метафора «живое знание» и проблема значения слова. Вестник Тверского государственного университета. Серия «Филология». 2007. № 12 [40]. Вып. 7 «Лингвистика и межкультурная коммуникация». С. 18-33.

18. Зинченко В. П. Живое знание. Самара: Изд-во Самар. гос. пед. ун-та, 1998. Ч. 1. $248 \mathrm{c.}$

19. Зинченко В.П. Миры сознания и структура сознания. Bonpocbl психологии. 1991. № 2. С. 15-36.

20.Зинченко В.П. О микроструктурном методе исследования познавательной деятельности. Эргономика: Труды ВНИИТЭ. 1972. Вып. 3. С. 77.

21.Зинченко В.П. Психологические основы педагогики. Москва: Гардарики, 2002. $431 \mathrm{c.}$ 
22. Зинченко В.П. Развитие зрения в контексте перспектив общего духовного развития человека. Вопросы психологии. 1988. № 6. С. $15-29$.

23. Зинченко Т.П. Память в экспериментальной и когнитивной психологии. Санкт-Петербург: Питер, 2002. 320 с.

24. Йоас Х. Креативность действия: пер. с нем. Санкт-Петербург: Алетейя, 2005. 320 с.

25. Карпенко 3.С. Аксіологічна психологія особистості. ІваноФранківськ: Лілея НВ, 2009. С. 225-257.

26. Кипнис М. Апельсиновый тренинг. Москва, 2008. 111 с.

27. Кон И.С. В поисках себя. Личность и ее самосознание. Москва: Изд. Политической литературы, 1984. 335 с.

28. Костюченко О.В. Метафоризація як психологічний ресурс потенційності майбутнього фахівця. International Journal of Education And Science (IJES). Vol. 2. No. 2. 2019. C. 50-51.

29. Лакофф Дж., Джонсон М. Метафоры, которыми мы живем. Теория метафоры: пер. с англ., фр., нем., исп., пол. под. ред. Н.Д. Арутюновой и М.А. Журинской. Москва: Прогресс, 1990. С. 397; С. $126-172$.

30. Лурия А. Р. Язык и сознание; под редакцией Е. Д. Хомской. Изд-во Моск. ун-та, 1979, 320 с.

31. Мазепова О. В. Метафора як засіб створення мовної картини світу. Мовні і концептуальні картини світу. Київ, 2004. Книга 2, № 12. C. 3 .

32. МакКормак Э. Когнитивная теория метафоры. Теория метафоры: пер. с англ., фр., нем., исп., пол. под. ред. Н.Д. Арутюновой и М.А. Журинской. Москва: Прогресс, 1990. С. 358-387.

33. Психологический словарь; под ред. В.П. Зинченко, Б.Г. Мещерякова. 2-е изд. Москва: Астрель, Транзит книга, 2004. С. 240.

34. Реан А.А. Акмеология личности. Психологический журнал. 2000. T. 21. № 3. C. $88-95$

35. Селіванова О.О. Актуальні напрями сучасної лінгвістики (аналітичний огляд). Київ, 1999. С. 81.

36. Смирнов С.Д. Образ мира как исходный пункт и результат любого познавательного процесса. Психология образа: Проблема активности психического отражения. Москва, 1985. С. 144.

37. Солсо Р.Л. Когнитивная психология: пер. с англ. Москва: Тривола, 1996. 600 с. 
38. Столин В.В. Самосознание личности. Москва: МГУ, 1983. 286 с.

39. Телия В.Н. Метафоризация и ее роль в создании языковой картины мира. Роль человеческого фактора в языке. Язык и картина мира. Москва, 1988. С. 317.

40. Терещук А.Д. Креативність як невід'ємний компонент інтелектуального розвитку особистості. Людина у світі духовної культури. Київ, 2002. Ч. 2. С. 43-44.

41. Франц М.-Л. фон. Психотерапия. Москва: Клуб Касталия, 2016. $250 \mathrm{c}$.

42. Ченки А. Семантика в когнитивной лингвистике. Фундаментальные направления современной американской лингвистики. Москва: Изд-во МГУ, 1997. С. 355.

43. Шрагіна Л.І. Технологія розвитку креативності. Київ: Шкільний світ, 2010. С. 53.

44. Anderson J.R., Bover G.H. Recognition and retrieval processes in free recall. Psychological Review, 1972. P. 97-123.

45. Bover G. N. Mental imagery and associative learning. In L.W. Gregg (Ed.): Cognition in learning and memory. New York: Willey, 1972. P. 51-88.

46. Jordan E. Essays in Criticism. Univ. Chicago Press, 1952, P. 113, $117,124$.

47. Lakoff G. Women, Fire and Dangerous Things. What categories reveal about mind. Chicago; L.: University of Chicago Press, 1987. P. 12.

48. Milner B. Disorders in learning and memory after temporal lobe lesions in man. Clinical Neurosurgery, 1972. P. 421-446.

49. Pylyshin Z.W. The "causal power" of mashines. Behavioral and Brain Sciences, 3, 1980. P. 442-444.

Information about the author: Kostyuchenko O. V.

Doctor of Psychological Sciences, Associate Professor, Assistant Professor at the Department of Psychology of the Kyiv National University of Culture and Arts 36, Eugene Konovalets str., Kyiv, 01601, Ukraine 


\section{MANAGEMENT ABILITIES OF PERSONALITY CULTURE MANAGER: THEORETICAL-EMPIRICAL ANALYSIS}

\section{Martynyshyn Ya. M.}

\section{INTRODUCTION}

Of all the problems that people face in the course of society's historical development, obviously the most difficult is the man's nature and his abilities. This is especially true of the managerial ability, as the ability of the individual to lead other people, to direct their life.

The problem of managerial abilities is quite popular and at the same time extremely complicated. On the one hand, this problem is so widespread that there is no need to be a specialist in any narrow field to get involved by suggesting own approach. On the other hand, the problem of abilities in recent years has been filled with a large number of different research approaches: psychodynamic (S. Freud ${ }^{1}$ ), which focuses on unconscious mental and emotional motives, as the basis of the dynamics of human abilities development; ego-psychological (E. Erikson ${ }^{2}$, E. Fromm ${ }^{3}$, K. Horney ${ }^{4}$ ), based on the fact that the person's ego through life goes through several universal stages of biological maturation in interaction with the sphere of social relations, developing a certain system of abilities; dispositional (G. Allport ${ }^{5}$, R. Cattell ${ }^{6}, \mathrm{H}$. Eysenck $^{7}$ ), which especially emphasizes persistent qualities (human traits) that are inherent in the individual and ensure the constancy of his behavior over time and changing situations; behavioral (B. Skinner ${ }^{8}$ ), which is based on the fact that personality abilities are formed and developed under the influence of the external social environment and are the result of its observations of social models (parents, teachers, friends, successful people,

\footnotetext{
${ }^{1}$ Freud S. Group Psychology and the Analysis of the Ego. New York : W. W. Norton \& Company, 1990. $144 \mathrm{p}$.

${ }^{2}$ Erikson E. Identity and the Life Cycle Paperback. New York : W. W. Norton \& Company, 1994. 192 p.

${ }^{3}$ Fromm E. The Sane Society. London : Routledge, 2001. 426 p.

${ }^{4}$ Horney K. New Ways in Psychoanalysis. New York : W. W. Norton \& Company, 2000. 320 p.

${ }^{5}$ Allport G. The Person in Psychology. Boston : Beacon Press, 1968. 440 p.

${ }^{6}$ Cattell R. The Inheritance of Personality and Ability. New York : Academic Press, 1982. 449 p.

${ }^{7}$ Eysenck H. Personality, genetics, and behavior. New York : Praeger, 1982. 330 p.

${ }^{8}$ Skinner B. The Shaping of a Behaviorist. New York : University Press, 1985. 384 p.
} 
etc.) in order to adapt to the environment; social-cognitive (A. Bandura 9 , J. Rotter ${ }^{10}$ ), which emphasizes that a person's abilities are the result of a complex interaction between the cognitive processes of the individual and their influence on the external social environment; cognitive (G. Kelly ${ }^{11}$ ) assumes that the individual's ability is not a passive result of the influence of the external social environment on the person, and, above all, depends on the ability of the cognitive interpretation by the person of that environment; the humanist (A. Maslow ${ }^{12}$ ), who denies psychoanalysis and behaviorism and it is based on the fact that man is the creator of personal abilities and lifestyle; phenomenological (C. Rogers ${ }^{13}$ ), which focuses on the formation and development of abilities, the inner life of the individual: his vision, feeling, experience; synthetic (L. Hjelle \& D. Ziegler ${ }^{14}$ ), which was formed on the basis of developments generalizations within the previous approaches.

However, despite the academic weight of these and many other studies, they do not shed enough light on the major issues of management theory and practice in management. There is no clear answer to questions about the nature of abilities, their composition and structure, interconnections and interdependencies. The question of ability diagnostics remains open, especially in cases where it is not possible to assess what will happen in the near future based on past experience.

The more we know about the managers' capabilities, the more questions arise about what realities are behind this concept. That is why any study of managerial abilities carries the danger of answering any minor question, leaving aside the main complexities of the problem. This is especially true of the study of managerial abilities in poorly researched areas of social activity. Such an industry is, first of all, an area of Ukrainian culture where such research has hardly been conducted.

\section{The essence, composition and structure of managerial abilities}

Cultural management activities, like any other activity, can be characterized by different levels of its quality parameters, performed with greater or less efficiency. This is determined by many factors, but above all depends on manager's personal and professional qualities, the need for

\footnotetext{
${ }^{9}$ Bandura A. Psychological modelling. New York : Aldine-Atherton, 1974. 256 p.

${ }^{10}$ Rotter J. The development and applications of social learning theory. New York : Praeger. $367 \mathrm{p}$.

${ }^{11}$ Kelly G. The Psychology of Personal Constructs. London : Routledge, 1992. 470 p.

${ }^{12}$ Maslow A. Motivation and personality. New York : Harper and Row, 1987. 293 p.

${ }^{13}$ Rogers C. A Way of Being. Boston : Houghton Mifflin, 1980. 416 p.

${ }^{14}$ Hjelle L., Ziegler D. Personality Theories. New York : McGraw-Hill Publishing Co., 1992. 624 p.
} 
which is determined by the content and nature of management activities. In other words, the main factors for its effectiveness are specific managerial skills. Not only efficiency, but even the very possibility of implementation of managerial functions depends on whether or not a person possesses such abilities.

The practical significance of this problem is obvious and due to the fact that only on the basis of its solution it is possible to develop scientifically sound and constructive procedures for the selection of cultural managers, as well as their preparation ${ }^{15}$.

Difficulties in studying management skills in the field of culture are related to the fact that the very concept of abilities is one of the most complex in psychology and it is still not fully disclosed. It is constantly slipping away from the disclosure of its essence and dissolves in other psychological concepts: knowledge, skills, intelligence, personal qualities, mental processes, etc. However, today it has some general characteristics, the main provisions of which are as follows.

Abilities are the individual-psychological characteristics of the individual, which are the conditions for the successful implementation of any activity, revealing differences in the dynamics of mastering the knowledge, skills and skills necessary for it. There are such features that distinguish abilities from other psychic phenomena: first, abilities are individual psychological characteristics that distinguish one person from another; secondly, these are only those features that are relevant to the success of the activity; third, abilities are not limited to the knowledge, skills and skills that have already been developed in humans, although they determine the ease and speed of their acquisition.

Management abilities are characterized by two main aspects: qualitative and quantitative. Considering from the side of qualitative features, abilities are a difficult complex of a person's psychological properties, which ensure the success of the activity. Quantitative characteristic of abilities involves determining the extent of their expression, the ability development level ${ }^{16}$.

In the structure of the cultural manager's abilities, it is advisable to distinguish two of their main categories: they are general and special

\footnotetext{
${ }^{15}$ Обгрунтування парадигми менеджмент-освіти у соціокультурній сфері. За ред. Я. М. Мартинишина. Біла Церква : Вид. Пшонківський О.В., 2017. 509 с.

16 Мартинишин Я.М., Коваленко Є.Я. Мистецтво управління й освітні технології підготовки менеджерів соціокультурної діяльності. Біла Церква : Вид. Пшонківський О.В., 2018. С. 179-180.
} 
abilities. The former determine the success of many, not many, activities. The second is specific and determines the effectiveness of any particular activity. Abilities are formed and developed in the activity based on incomes. These are the morphological and functional features of the nervous system and the body as a whole, which act as natural and biologically conditioned, innate prerequisites for the abilities development.

Another starting and general position of the abilities psychology, in our opinion, it is the allocation of three qualitatively different levels of their presentation is actually abilities, talent (talent) and genius. In the theory of ability it is very important, but it has been still not resolved the question of the degree of inheritance, innate ability. Although, of course, abilities develop in ontogeny and first of all, under the influence of activity development, under the environmental factors influence, they also have a very strong hereditary dependence. The more general the ability is, the more genetically dependent and vice versa. The higher the level of inherited ability, the more likely it will be and the more it will develop not in spite of further living conditions, but in spite of them. Finally, abilities are not isolated entities, but inherent personality traits that interact with all other personal qualities. The abilities development is therefore inseparable from the individual development as a whole. They, influencing the nature of the personal qualities formation and personality as a whole, themselves experience the actions of the personality in the formation process. The abilities development and personality is a two-fold process. Thus the abilities concept finds its place in the general structure of psychological concepts. It is as if an intermediate link between two fundamental psychological concepts: activity and personality.

Extremely general status of the abilities concept, their inseparable connection both with activity, and with the personality cause difficulties of managerial abilities studying. The essence of these difficulties is as follows. Every cultural management activity has three main segments: 1) proper activity, organizational and administrative, connected with the organization of management of any cultural institution, as a system; 2) staffing is related to managing people, organizing interpersonal interactions; 3) production-creative, directly connected with the organization of creative-technological process, with its operational 
management ${ }^{17}$. Management effectiveness is determined by how well a manager is able to provide three of these different segments, as well as coordinate them with each other. The first it is an activity, organizational and administrative requires the development of general management skills and abilities, the ability to effectively organize joint activities. The second it is personnel, personal segment requires the availability of qualitatively other abilities that provide effective interpersonal interaction, organization and management of people. Such abilities will be played not by special or even general abilities, but by basic personal qualities. The third it is the production and creative segment involves the presence of the manager's professional qualities and his special abilities.

In addition, reconciling these three segments in the management process which requires another type of capability: a coordination, overall organizational plan, which again is linked to the manager's top personal qualities. Because of this content, the composition of management capabilities in the cultural sphere is very wide. They are not only properties that have professional specificity, but also many others, in fact, the head's personal qualities. Therefore, the question of managerial ability is often discussed in connection with the problem of the general structure of the leader's personality, and sometimes and they are replaced by it. The notion of abilities is identified with the personal qualities concept of the leader. This is the most characteristic feature of modern views on managerial abilities. As a result of this approach, the lists of managerial capabilities appear to be very extensive; they include very different in the degree of generalization and character traits of the psyche and the manager's personality.

This approach has the right to exist; it reflects the real complexity of management, the variety of requirements that it makes to the individual. In foreign psychology, it is developed into a "theory of traits" that contains extensive lists of such abilities, as well as in a number of other areas. However, this approach is referred to as collectible. It does not answer the question of what structure of management capabilities, how they are interconnected and what features of their organization. To better understand this really complex issue, let's note a number of groups of managerial qualities that are usually distinguished from their totality. They

\footnotetext{
${ }^{17}$ Мартинишин Я.М., Хлистун О.С. Ієрархія як феномен організаційної культури. Вісник Київського національного університету культури і мистецттв. Серія: Менеджмент соціокультурної діяльності. 2019. Вип. 1. С. 7-31.
} 
are either management capabilities in their own sense, or contribute to the effective execution of management activities.

First, it is a group of basic characteristics of the manager's personality, which is denoted by the concept of managerial characteristics. All of them are either necessary for management activity, or desirable for it, because they cause all things being equal and a high level of its success. In addition, they are also a factor that determines the preference for the personality of the choice of management activities, inclination to it. These characteristics are divided into two subgroups (Fig. 1). The first is the general social, so-called biographical characteristics inherent in an effective manager (socio-status, cultural, educational, gender-age, etc.). The second is the personal qualities of an effective manager (dominance, self-confidence, independence, striving for achievement, entrepreneurialism, emotional stability, stress resistance, responsibility, reliability, creativity, sociability).

Secondly, it is a group of managerial abilities. It includes only those features that directly and most significantly influence cultural management, as determined by its content and requirements. This group is most often regarded as a managerial capacity in the narrow sense. It is also divided into two subgroups. The first is the general organizational and psychological abilities (psychological selectivity, practical psychological reason, psychological tact, vigor, demandingness, criticality, inclination to organizational work). They determine the effectiveness of this type of activity as a whole. The second is the individual management capabilities that ensure the effective performance of individual management functions (goal setting, forecasting, planning, organizing, decision-making, motivation, communication, control and adjustment); solving partial, though important, management tasks.

Two of these groups are distinguished by the so-called activityfunctional criterion and by what properties of the psyche and personality quality are required for activity. However, in the management psychology, there is another criterion for the abilities' allocation, it is structural and psychological. According to it, the basis of ability allocation is not the structure and content of activity, and the structure of the psyche. According to this criterion, first, distinguish manifestations in the management of general and special abilities. Secondly, abilities are structured according to the main classes of mental processes: cognitive, regulatory, communicative. 


\begin{tabular}{|c|c|}
\hline \multicolumn{2}{|c|}{ Allocation of abilities by activity-functional criterion } \\
\hline $\begin{array}{l}\text { 1. Qualities that indirectly } \\
\text { implement functions } \\
\text { managerial abilities } \\
\text { (managerial characteristics) }\end{array}$ & \\
\hline $\begin{array}{l}\text { Personal qualities: } \\
\text { 1) dominance, confidence } \\
\text { in itself, independence, desire } \\
\text { to achievements and enterprise; } \\
\text { 2) emotional stability, } \\
\text { stress resistance; } \\
\text { 3) responsibility and reliability; } \\
\text { 4) creativity; } \\
\text { 5) sociability. }\end{array}$ & $\begin{array}{l}\begin{array}{l}\text { 2. Qualities that } \\
\text { are directly managerial } \\
\text { (manager's own ability) }\end{array} \\
\text { General organizational and } \\
\text { psychological abilities: } \\
\text { 1) psychological selectivity, } \\
\text { practical psychological } \\
\text { mind and psychological tact; } \\
\text { 2) energy; } \\
\text { 3) demanding and critical; } \\
\text { 4) propensity for organizing } \\
\quad \text { work } \\
\text { Local: } \\
\text { 1) laying unit; } \\
\text { 2) forecasting and planning; } \\
\text { 3) organizing; } \\
\text { 4) decision-making; } \\
\text { 5) motivation; } \\
\text { 6) communication; } \\
\text { 7) control and adjustment. }\end{array}$ \\
\hline \multicolumn{2}{|c|}{$\begin{array}{l}\text { Groups of managerial qualities } \\
\text { and the overall structure of the manager's abilities }\end{array}$} \\
\hline \multicolumn{2}{|c|}{$\begin{array}{l}\text { 3. The qualities that are the psychological basis of the first two groups, } \\
\text { which determine the level of their abilities development: }\end{array}$} \\
\hline 1) cognitive; 2) re & $y$; 3) communicative \\
\hline
\end{tabular}
Fig. 1. Groups of managerial qualities and general structure of abilities the personality of the cultural manager


Thus, the general structure of managerial abilities of the cultural manager should be based on the complementary use of two criteria, they are activity-functional and structural-psychological. As a result, there are three main groups of qualities that are either directly managerial abilities, or indirectly implement the functions of the manager's abilities (i.e., affect the management success and managerial characteristics). The third group there is the psychological basis for the first two, which determines the level of their abilities development.

\section{Statistical and mathematical study of managers' abilities and the success of cultural management}

The research methodology includes the following steps.

I. The statistics collection on the object of study, which involves surveying the staff of cultural institutions and quantifying their ability of managers of these institutions and their management's success:

$$
\left\{\mathrm{Z}_{i} ; \mathrm{U}\right\} \text {, }
$$

where $Z_{i}-$ level of ability of the $i$-th type, points; $U$ - management success, points.

The level of ability and management success is estimated on a 100-point scale. The research covers 39 cultural institutions in Ukraine, including: theaters are 13; concert organizations are 14; museums are 12 . The total number of respondents is 195 , of which representatives are: the theater sphere is 65; philharmonic are 67; museums are 63.

The following three groups of abilities are subject to evaluation:

1 group. Manager's personal qualities: 1) dominance, self-confidence, independence, aspiration for achievement and enterprise; 2) emotional stability, stress resistance; 3) responsibility and reliability; 4) creativity; 5) sociability.

2 group. General organizational and psychological abilities: 1) psychological selectivity, practical psychological reason and psychological tact; 2) energy; 3) demanding and critical; 4) propensity for organizational work.

3 group. The basic abilities that underlie the two previous groups of managerial abilities: 1) cognitive; 2) regulatory; 3) communicative.

II.Summary statistics and calculation of general indicators:

1) systematization of data by ability groups and types of cultural institutions; 
2) calculation of average values of ability indicators $\left(\check{Z}_{i}\right.$; $\left.\check{Z}\right)$ and success of managers ( $\breve{U})$ for each type of cultural institution and group of abilities:

$$
\check{Z}_{i}=\Sigma Z_{i} / \mathrm{N} ; \check{Z}=\Sigma \check{Z}_{i} / \mathrm{I} ; \check{\mathrm{U}}=\Sigma \mathrm{U} / \mathrm{N} \text {, }
$$

where $\mathrm{N}$ - number of respondents of a particular type of cultural institution;

I - the number of types of abilities in the group.

III. Building profiles of cultural managers' abilities based on the average values of their indicators:

$$
\left\{\check{Z}_{i}\right\} .
$$

IV. Drawing portraits capabilities theater, philharmonic and museum managers, reflecting their structural characteristics and features. The construction of these portraits is based on the distribution of all types of abilities by the appropriate level zones and subzones:

Abilities' high level:

- very high (professional) $\check{Z}_{i} \geq 91$;

- moderately high (elevated) $\check{Z}_{i}=81-90$;

Abilities' average level:

- upper average $\breve{Z}_{i}=71-80$;

- lower middle $\check{Z}_{i}=61-70$;

Low ability level:

- moderately low $\check{Z}_{i}=51-60$;

- very low $\check{Z}_{i} \leq 50$.

V. Analytical grouping of cultural institutions by the average level of managers' abilities $(\breve{Z})$ and identification of patterns of their influence on the management success $(\breve{U})$ :

$$
\check{Z} \rightarrow \text { Ŭ. }
$$

VI. Statistical and mathematical models development of management success depending on the level of mismatch of managers' abilities:

$$
\tilde{U}=\operatorname{Fc}\left(\Delta Z_{i}\right) \text {, }
$$

where $\tilde{U}$ - effective indicator of a model of a particular type of cultural institution (management success), in points; $\Delta Z_{i}$ - factor factors of the model (levels of discrepancy of manager's abilities), in points. Factor indicators are determined for each respondent and ability group by the following formula: 


$$
\Delta \mathrm{Z}_{i}=100-\mathrm{Z}_{i}
$$

where 100 - normative value of abilities, points.

Building models involves the following steps:

Step 1. Verification of aggregated and systematic statistical sample data for their compliance with the established requirements for statistical and mathematical modeling and representativeness. The results of such verification should show whether the information is sufficient, both in terms of number of units and variation of features, and in the consistency of its aggregates with normal distribution, and whether it is representative of the aggregate ${ }^{18}$.

The verification showed that the initial information is sufficient both in terms of the number of observation units $(\mathrm{N} / \mathrm{I} \geq 8)$ and the variation of the resultant and factor traits (var $>10 \%)$ and the agreement of its aggregates with the normal distribution $(\tau<3 \sigma)$; it is also representative of the general population since its actual error at a given probability level of 0.95 did not exceed the limit $(\Delta \mathrm{E}<\Delta \mathrm{Elim})$. Therefore, this selective information can be used to model the relationship between management success and managerial capacity mismatches, with the dissemination and interpretation of the results obtained across the entire cultural establishment in Ukraine (up to 3\% error).

Step 2. Identify the cause-effect relationship between factorial and resultant attributes, using grouping and graphical methods, and construct models in a general symbolic form.

As the analysis confirms, the relationship between the score (Ũ) and the factors $\left(\Delta \mathrm{Z}_{i}\right)$ is inverse, and the form of the relationship is close to linear. Therefore, the general view of the statistical and mathematical models will be as follows:

$$
\tilde{\mathrm{U}}=100-\Sigma a_{i} \Delta \mathrm{Z}_{i}
$$

where 100, $a_{i}$ - model parameters, in particular: 100 is free member (maximum value of management success); ai is regression coefficients.

More specifically, for each of the above three ability groups, the models will look like this:

$$
\begin{gathered}
\tilde{\mathrm{U}}=100-a_{1} \Delta \mathrm{Z}_{1}-a_{2} \Delta \mathrm{Z}_{2}-a_{3} \Delta \mathrm{Z}_{3}-a_{4} \Delta \mathrm{Z}_{4}-a_{5} \Delta \mathrm{Z}_{5} ; \\
\tilde{\mathrm{U}}=100-a_{1} \Delta \mathrm{Z}_{1}-a_{2} \Delta \mathrm{Z}_{2}-a_{3} \Delta \mathrm{Z}_{3}-a_{4} \Delta \mathrm{Z}_{4} ; \\
\tilde{\mathrm{U}}=100-a_{1} \Delta \mathrm{Z}_{1}-a_{2} \Delta \mathrm{Z}_{2}-a_{3} \Delta \mathrm{Z}_{3},
\end{gathered}
$$

where $a_{1} \ldots a_{5}$ - regression coefficients.

\footnotetext{
${ }^{18}$ Сріна А.М. Статистичне моделювання та прогнозування. Київ : КНЕУ, 2011. 170 с.
} 
Step 3. Modeling in numerical form. This work is done on a computer and includes correlation calculations and reliability evaluation of communication characteristics: the numerical values of the regression coefficients $\left(a_{i}\right)$, the multiple and partial correlation coefficients $\left(C, c_{i}\right)$ and determinations $\left(D, d_{i}\right)$, the actual values of the Fisher criteria $(F)$ and Student's $\left(t_{i}\right)$ are determined. Using the $t$ - and $F$-criteria you can estimate the reliability of the regression coefficients and the model as a whole. The correlation coefficients estimate the strength of the relationship and the coefficients of determination the proportion of variation in the productive trait, which is due to the influence of the factor traits.

VII. Statistical and mathematical analysis and forecasting. With the help of the developed numerical models it is possible to carry out a deep analysis of the management effectiveness (success). In particular, using the regression coefficients $\left(a_{i}\right)$, we determine the influence degree of the corresponding factor $\left(\Delta Z_{i}\right)$ on the resultant index ( $\left.\tilde{U}\right)$, in points: with the change of an individual factor per unit the resultant indicator will change to the corresponding coefficient. Knowing the magnitude of the variation of each factor, we find the maximum change in the resultant indicator, and by the coefficients of determination $\left(D, d_{i}\right)$ we conclude what proportion of its variation is explained by the influence of all or a single factor that is part of the model. Models can also be used to predict management success. Substituting the specific values of the factors-factors $\left(\Delta Z_{i}\right)$ into the model, we predict the expected values of the resultant indicator (U)

\section{Results and discussion.}

The main results of the study are presented in Tables $1-4$. The output, which builds on the following results, it is to build managers' ability profiles. As it can be seen from the tab. 1, the indicators of profiles by types of cultural institutions and groups of abilities are different. In some institutions they are very high, in others, on the contrary, very low, in others they are on average.

Among the personal qualities of cultural managers, philharmonic managers have the greatest dominance, confidence, independence, desire for achievement and enterprise, as well as emotional stability and stress resistance. The greatest responsibility, reliability and camaraderie are inherent in museum managers. The highest creativity is characteristic of theater managers, who also have high levels of dominance and entrepreneurship. 
In terms of general organizational and psychological abilities, philharmonic managers have the highest indicators of energy and aptitude for organizational work. Psychological selectivity, practical psychological reason and psychological tact are the best in museum managers, and the demanding and critical are theatrical managers.

Table 1

\section{Profiles of cultural managers' abilities}

\begin{tabular}{|c|c|c|c|}
\hline Abilities & Theaters & Philharmonic & Museums \\
\hline \multicolumn{4}{|c|}{1 group. Manager's personal qualities } \\
\hline $\begin{array}{l}\text { Dominance, self-confidence, } \\
\text { independence, striving for achievement } \\
\text { and entrepreneurship } \check{Z}_{1}\end{array}$ & 85 & 94 & 43 \\
\hline Emotional stability, stress resistance $\check{Z}_{2}$ & 46 & 83 & 51 \\
\hline Responsibility and reliability $\check{Z}_{3}$ & 64 & 48 & 77 \\
\hline Creativity $\check{Z}_{4}$ & 91 & 90 & 76 \\
\hline Sociability $\breve{Z}_{5}$ & 61 & \begin{tabular}{|l|l}
58 & \\
\end{tabular} & 70 \\
\hline \multicolumn{4}{|c|}{2 group. General organizational and psychological abilities } \\
\hline $\begin{array}{l}\text { Psychological selectivity, practical } \\
\text { psychological reason and psychological } \\
\text { tact } \breve{Z}_{1}\end{array}$ & 76 & 51 & 78 \\
\hline Energy $\check{Z}_{2}$ & 60 & 90 & 45 \\
\hline Demand and criticality $\check{Z}_{3}$ & 92 & 59 & 61 \\
\hline Propensity for organizational work $\check{Z}_{4}$ & 45 & 95 & 75 \\
\hline \multicolumn{4}{|c|}{3 group. The basic abilities that underlie the previous ones } \\
\hline Cognitive $\check{Z}_{1}$ & 72 & \begin{tabular}{|c|}
46 \\
\end{tabular} & 77 \\
\hline Regulatory $\check{Z}_{2}$ & 90 & 80 & 41 \\
\hline Communicative $\check{Z}_{3}$ & 41 & 92 & 65 \\
\hline
\end{tabular}

The highest values of basic abilities are also distributed differently between cultural institutions. Cognitive abilities prevail in museum managers, regulatory is in theatrical, and communicative is in the philharmonic. An even deeper analysis of the abilities of cultural managers can be made on the basis of portraits of abilities (Tab. 2).

From this analysis, the theatrical manager's abilities are almost evenly distributed between the high, middle and lower levels of the portrait (four abilities in each group). These managers have two abilities in the professional 
level: demanding and critical and creative. Regulatory, dominant and enterprising are also quite high. Communication skills, aptitude for organizational work, emotional stability and stress resistance are at the bottom. The average ability level of theater managers is 69 points.

Table 2

\section{Portraits of cultural managers' abilities}

\begin{tabular}{|c|c|c|}
\hline $\begin{array}{l}\text { Theatrical } \\
\text { manager }\end{array}$ & $\begin{array}{c}\text { Philharmonic } \\
\text { manager }\end{array}$ & $\begin{array}{l}\text { Museum } \\
\text { manager }\end{array}$ \\
\hline 1 & 2 & 3 \\
\hline \multicolumn{3}{|c|}{ High level of ability } \\
\hline \multicolumn{3}{|c|}{ Very high (professional) $\check{Z}_{i} \geq 91$} \\
\hline $\begin{array}{l}\text { Demand } \\
\text { and Criticality (92); } \\
\text { Creativity (91) }\end{array}$ & $\begin{array}{l}\text { Aptitude for } \\
\text { organizational work (95); } \\
\text { Dominance, self- } \\
\text { confidence, } \\
\text { independence, striving } \\
\text { for achievement and } \\
\text { entrepreneurship (94); } \\
\text { Communicative (92) }\end{array}$ & \\
\hline \multicolumn{3}{|c|}{ Moderately high (elevated) $\check{Z}_{i}=81-90$} \\
\hline $\begin{array}{l}\text { Regulability (90); } \\
\text { Dominance, self- } \\
\text { confidence, } \\
\text { independence, striving } \\
\text { for achievement and } \\
\text { entrepreneurship (85) } \\
\end{array}$ & $\begin{array}{l}\text { Creativity (90); } \\
\text { Energy (90); } \\
\text { Emotional stability, stress } \\
\text { resistance (83) }\end{array}$ & \\
\hline \multicolumn{3}{|c|}{ Average level of ability } \\
\hline \multicolumn{3}{|c|}{ The upper middle $\check{Z}_{i}=71-80$} \\
\hline $\begin{array}{l}\text { Psychological selectivity, } \\
\text { practical psychological } \\
\text { reason and psychological } \\
\text { tact (76); } \\
\text { Cognitive (72) }\end{array}$ & Regulatory (80) & $\begin{array}{l}\text { Psychological selectivity, } \\
\text { practical psychological } \\
\text { reason and psychological } \\
\text { tact (78); } \\
\text { Responsibility and } \\
\text { Reliability (77); } \\
\text { Cognitive (77); } \\
\text { Creativity (76); } \\
\text { Aptitude for } \\
\text { organizational work (75) }\end{array}$ \\
\hline
\end{tabular}


Table 2 (ending)

\begin{tabular}{|c|c|c|}
\hline 1 & 2 & 3 \\
\hline \multicolumn{3}{|l|}{ Lower average $\check{Z}_{i}=61-70$} \\
\hline $\begin{array}{l}\text { Responsibility } \\
\text { and reliability (64); } \\
\text { Sociability (61) }\end{array}$ & & $\begin{array}{l}\text { Sociability (70); } \\
\text { Communicativeness (65); } \\
\text { Demand } \\
\text { and Criticality (62) }\end{array}$ \\
\hline \multicolumn{3}{|l|}{ Low ability level } \\
\hline \multicolumn{3}{|c|}{ Moderately low $\check{Z}_{i}=51-60$} \\
\hline Energy (60) & $\begin{array}{l}\text { Demand } \\
\text { and Criticality (59); } \\
\text { Sociability (58); } \\
\text { Psychological selectivity, } \\
\text { practical psychological } \\
\text { reason and psychological } \\
\text { tact (51) }\end{array}$ & $\begin{array}{l}\text { Emotional stability, } \\
\text { stress resistance (51) }\end{array}$ \\
\hline \multicolumn{3}{|l|}{ Very low $\check{Z}_{i} \leq 50$} \\
\hline $\begin{array}{l}\text { Emotional stability, } \\
\text { stress resistance (46); } \\
\text { Aptitude for } \\
\text { organizational work (45); } \\
\text { Communicative (41) }\end{array}$ & $\begin{array}{l}\text { Responsibility and } \\
\text { reliability (48); } \\
\text { Cognitive (46) }\end{array}$ & $\begin{array}{l}\text { Energy (45); } \\
\text { Dominance, } \\
\text { self-confidence, } \\
\text { independence, striving } \\
\text { for achievement and } \\
\text { entrepreneurship (43); } \\
\text { Regulability (41) }\end{array}$ \\
\hline
\end{tabular}

Philharmonic managers' abilities are concentrated in the upper and lower portions of the portrait. In the middle zone, there is only one type of ability (regulatory). The higher zone includes six abilities: aptitude for organizational work, dominance, entrepreneurialism and communication (professional subzone); creativity, energy, emotional stability and stress resistance (moderately high subzones), which is a significant advantage of these managers among other cultural managers. At the lowest level there are cognitive abilities, responsibility and reliability, which is the weak point of this category of managers. The average ability of philharmonic managers is 74 points.

Unlike theater and philharmonic managers, museum managers do not have any top-level ability, which is their weakness. Another feature is that $2 / 3$ of their abilities are concentrated in the middle zone of the portrait (psychological selectivity, responsibility and reliability, cognitive, 
creativity, aptitude for organizational work, etc.) and only $1 / 3$ is in the lower zone (regulatory, dominant, energy, emotional stability and stress resistance). The average ability of museum managers is 63 points. All those abilities of managers in the lower and middle levels of the portrait need improvement. Their deviation from the standard is a reserve for improving the management efficiency. Therefore, they must be further developed to enhance the management skills in these areas. So, in particular, the communicative abilities development is very relevant for theatrical managers, the cognitive for the philharmonic, and the regulatory abilities for the museum managers.

Analytical grouping of cultural institutions by the level of managers' abilities confirms the existence of a regular direct correlation between the abilities indicators (the opposite between the indicators of deviation from the standard) and the success of management (Tab. 3).

The influence of managers' abilities on management success can be further analyzed and predicted on the basis of developed statistical and mathematical models (Tab. 4), which are sufficiently reliable for practical purposes, since the actual values of the $t$ and $F$ criteria were many times greater than the critical values. Multiple correlation coefficients of these models $(\mathrm{C}=-0.88 \ldots 0.90)$ indicate strong feedback between the resultant (U) and factor $\left(\Delta \mathrm{Z}_{i}\right)$ traits.

Table 3

Grouping of cultural institutions by the level of managers' abilities and identifying their impact on management success

\begin{tabular}{|c|c|c|c|c|c|}
\hline \multicolumn{2}{|c|}{ Theaters } & \multicolumn{2}{c|}{ Philharmonic } & \multicolumn{2}{c|}{ Museums } \\
\hline$[\check{Z}]$ & Ǔ & {$[\check{Z}]$} & $\check{U}$ & {$[\check{Z}]$} & U \\
\hline$\leq 60$ & 54 & $\leq 60$ & 59 & $\leq 60$ & 52 \\
\hline $61-80$ & 71 & $61-80$ & 76 & $61-80$ & 70 \\
\hline$\geq 81$ & 95 & $\geq 81$ & 98 & $\geq 81$ & 91 \\
\hline Average & 75 & Average & 80 & Average & 67 \\
\hline
\end{tabular}

With the change of a certain factor to $+/-\Delta Z_{i}$, the resultant index will change by the value of the product of this change and the corresponding regression coefficient $\left(a_{i}\right)$, i.e.:

$$
\Delta \tilde{\mathrm{U}}_{i}=-/+\Delta \mathrm{Z}_{i} \cdot a_{i} .
$$


For example, by increasing the cognitive ability of managers by 10 points, which means reducing the mismatch of this type of abilities by 10 points $\left(\Delta Z_{1}=-10\right)$, the success of managing theater, philharmonic and museum managers will increase, on average, by: $\Delta \tilde{U}_{1}=(-10)$. $(-0.334)=3.34 ; \Delta \tilde{U}_{1}=(-10) \cdot(-0.169)=1.69 ; \Delta \tilde{U}_{1}=(-10) \cdot(-0.508)=5.08$ points.

We have considered only one of the possible combinations of changing cultural managers' abilities, but there may be a lot and at most different types of cultural institutions and ability groups. For example, by reducing the inconsistency of theatrical managers' abilities in the group of general organizational and psychological abilities according to the above four factors (psychological selectivity $\Delta Z_{1}$, vigor $\Delta Z_{2}$, demanding and criticality $\Delta Z_{3}$, tendency to organizational work $\Delta Z_{4}$ ), respectively, by 15 , $20,4,25$, the success of management at the expense of each of them will increase accordingly by: $\Delta \tilde{\mathrm{U}}_{1}=15 \cdot 0.296=4.4 ; \quad \Delta \tilde{\mathrm{U}}_{2}=20 \cdot 0.189=3.8$; $\Delta \tilde{\mathrm{U}}_{3}=5 \cdot 0.377=1.9 ; \quad \Delta \tilde{\mathrm{U}}_{4}=25 \cdot 0.138=3.5$ points; and a total of $\Delta \tilde{\mathrm{U}}=13.6$ points. The predicted management success in theaters will be $\tilde{\mathrm{U}}=\breve{U}+\Delta \tilde{\mathrm{U}}=75+13.6=88.6$ points.

Table 4

\section{Statistical and mathematical models of management success depending on the managers' ability level}

\begin{tabular}{|l|c|}
\hline $\begin{array}{c}\text { Cultural } \\
\text { institutions }\end{array}$ & \multicolumn{1}{c|}{ Models and their characteristics } \\
\hline \multicolumn{1}{|c|}{1} & \multicolumn{1}{c|}{ 1 group. The manager's personal qualities } \\
\hline \multicolumn{3}{|c|}{ Theaters } & $\begin{array}{l}\tilde{\mathrm{U}}=100-0.254 \Delta \mathrm{Z}_{1}-0.108 \Delta \mathrm{Z}_{2}-0.212 \Delta \mathrm{Z}_{3}-0.292 \Delta \mathrm{Z}_{4}-0.134 \Delta \mathrm{Z}_{5} \\
\mathrm{C}=-0.88 ; \mathrm{D}=0.77 ; \mathrm{d}_{1}=0.20 ; \mathrm{d}_{2}=0.08 ; \mathrm{d}_{3}=0.16 ; \mathrm{d}_{4}=0.22 ; \mathrm{d}_{5}=0.11\end{array}$ \\
\hline Philharmonic & $\begin{array}{l}\tilde{\mathrm{U}}=100-0.281 \Delta \mathrm{Z}_{1}-0.204 \Delta \mathrm{Z}_{2}-0.137 \Delta \mathrm{Z}_{3}-0.263 \Delta \mathrm{Z}_{4}-0.115 \Delta \mathrm{Z}_{5} \\
\mathrm{C}=-0.89 ; \mathrm{D}=0.79 ; \mathrm{d}_{1}=0.22 ; \mathrm{d}_{2}=0.16 ; \mathrm{d}_{3}=0.11 ; \mathrm{d}_{4}=0.21 ; \mathrm{d}_{5}=0.09\end{array}$ \\
\hline \multirow{2}{*}{ Museums } & $\begin{array}{l}\tilde{\mathrm{U}}=100-0.126 \Delta \mathrm{Z}_{1}-0.139 \Delta \mathrm{Z}_{2}-0.287 \Delta \mathrm{Z}_{3}-0.254 \Delta \mathrm{Z}_{4}-0.194 \Delta \mathrm{Z}_{5} \\
\mathrm{C}=-0.88 ; \mathrm{D}=0.78 ; \mathrm{d}_{1}=0.10 ; \mathrm{d}_{2}=0.11 ; \mathrm{d}_{3}=0.22 ; \mathrm{d}_{4}=0.20 ; \mathrm{d}_{5}=0.15\end{array}$ \\
\hline Theaters & group. General organizational and psychological abilities \\
\hline \multirow{2}{*}{ Philharmonic } & $\begin{array}{l}\tilde{\mathrm{U}}=100-0.296 \Delta \mathrm{Z}_{1}-0.189 \Delta \mathrm{Z}_{2}-0.377 \Delta \mathrm{Z}_{3}-0.138 \Delta \mathrm{Z}_{4} \\
\mathrm{C}=-0.90 ; \mathrm{D}=0.81 ; \mathrm{d}_{1}=0.24 ; \mathrm{d}_{2}=0.15 ; \mathrm{d}_{3}=0.31 ; \mathrm{d}_{4}=0.11\end{array}$ \\
\hline \multirow{2}{*}{$\begin{array}{l}\tilde{\mathrm{U}}=100-0.154 \Delta \mathrm{Z}_{1}-0.312 \Delta \mathrm{Z}_{2}-0.189 \Delta \mathrm{Z}_{3}-0.345 \Delta \mathrm{Z}_{4} \\
\text { Museums }\end{array}$} & $\begin{array}{l}\tilde{\mathrm{U}}=100-0.325 \Delta \mathrm{Z}_{1}-0.158 \Delta \mathrm{Z}_{2}-0.273 \Delta \mathrm{Z}_{3}-0.244 \Delta \mathrm{Z}_{4} \\
\mathrm{C}=-0.89 ; \mathrm{D}=0.80 ; \mathrm{d}_{1}=0.26 ; \mathrm{d}_{2}=0.13 ; \mathrm{d}_{3}=0.22 ; \mathrm{d}_{4}=0.19\end{array}$ \\
\hline
\end{tabular}


Table 4 (ending)

\begin{tabular}{|l|l|}
\hline \multicolumn{1}{|c|}{1} & \multicolumn{1}{c|}{2} \\
\hline \multicolumn{2}{|c|}{ 3 group. The basic abilities that underlie the previous ones } \\
\hline \multirow{2}{*}{ Theaters } & $\tilde{U}=100-0.334 \Delta \mathrm{Z}_{1}-0.485 \Delta \mathrm{Z}_{2}-0.181 \Delta \mathrm{Z}_{3}$ \\
& $\mathrm{C}=-0.88 ; \mathrm{D}=0.78 ; \mathrm{d}_{1}=0.26 ; \mathrm{d}_{2}=0.38 ; \mathrm{d}_{3}=0.14$ \\
\hline \multirow{2}{*}{ Philharmonic } & $\tilde{\mathrm{U}}=100-0.169 \Delta \mathrm{Z}_{1}-0.384 \Delta \mathrm{Z}_{2}-0.447 \Delta \mathrm{Z}_{3}$ \\
& $\mathrm{C}=-0.89 ; \mathrm{D}=0.80 ; \mathrm{d}_{1}=0.13 ; \mathrm{d}_{2}=0.31 ; \mathrm{d}_{3}=0.36$ \\
\hline \multirow{2}{*}{ Museums } & $\tilde{U}=100-0.508 \Delta \mathrm{Z}_{1}-0.147 \Delta \mathrm{Z}_{2}-0.345 \Delta \mathrm{Z}_{3}$ \\
& $\mathrm{C}=-0.88 ; \mathrm{D}=0.77 ; \mathrm{d}_{1}=0.39 ; \mathrm{d}_{2}=0.11 ; \mathrm{d}_{3}=0.27$ \\
\hline
\end{tabular}

With the decrease in the same size of abilities of philharmonic and museum managers, the management success in philharmonic and museums will increase respectively by $18.1,15.5$ points and will make $98.1,82.5$ points, respectively.

Similar predictive calculations can be made for other ability groups with a variety of factor combinations.

\section{CONCLUSIONS}

The research results allow us to reach the following conclusions:

1. Existing methodological approaches (psychodynamic, egopsychological, dispositional, behavioral, social-cognitive, cognitive, humanistic, phenomenological, synthetic, etc.) do not give a definite answer about the nature, composition, structure, interconnections and management interdependencies. This is especially true of cultural management.

2. The manager's abilities, they are individual psychological characteristics, which are the conditions for successful management. They are formed in the process of activity on the basis of natural inclinations and develop in ontogeny and under the influence of mastering the practice of management and environmental factors.

3. Managerial ability is the intermediate link between the activity and the manager's personality. Therefore, in determining the composition of the cultural manager's capabilities, it is necessary to proceed from the structure of his activity, which includes the following segments: organizational and administrative, which requires developed general management skills; a staff who needs interpersonal skills; creative and production that desires special abilities of work in a certain field of culture.

4. It has been proved that the most accurate structure of the cultural manager's abilities can be determined on the basis of activity-functional 
and structural-psychological criteria. On this basis, there are three main groups of manager qualities that are either directly managerial, or indirectly implement the functions of ability. The third group is the psychological basis for the first two.

5 . With the help of the offered statistical and mathematical tools it is possible to carry out a deep quantitative analysis of abilities indicators and management efficiency, as well as to simulate and predict the interdependence of these indicators in the theatrical, philharmonic and museum branches of culture in Ukraine.

The obtained results are new and can be used to identify reserves for improving the performance of cultural managers and developing strategies for improving their training and skills development in the development and development of relevant capabilities.

\section{SUMMARY}

The problem of managerial abilities of cultural managers is being considered. Particular attention is paid to the psychological features of the managerial abilities nature, their composition, structure and interdependencies. The results of empirical research aimed at revealing the current level of managerial abilities development of cultural managers in relation to their management success are presented. A mathematical and mathematical toolkit has been offered, which allows to carry out a deep quantitative analysis of abilities' indicators and management efficiency, as well as to carry out modeling and forecasting the interdependence of these indicators in the theatrical, philharmonic and museum branches in Ukrainian culture.

\section{REFERENCES}

1. Freud S. Group Psychology and the Analysis of the Ego. New York: W.W. Norton \& Company, 1990. 144 p.

2. Erikson E. Identity and the Life Cycle Paperback. New York : W.W. Norton \& Company, 1994. 192 p.

3. Fromm E. The Sane Society. London : Routledge, 2001. 426 p.

4. Horney K. New Ways in Psychoanalysis. New York : W.W. Norton \& Company, 2000.320 p.

5. Allport G. The Person in Psychology. Boston : Beacon Press, 1968. $440 \mathrm{p}$.

6. Cattell R. The Inheritance of Personality and Ability. New York : Academic Press, 1982. 449 p. 
7. Eysenck H. Personality, genetics, and behavior. New York : Praeger, $1982.330 \mathrm{p}$.

8. Skinner B. The Shaping of a Behaviorist. New York : University Press, 1985.384 p.

9. Bandura A. Psychological modelling. New York : Aldine-Atherton, 1974. $256 \mathrm{p}$.

10. Rotter J. The development and applications of social learning theory. New York : Praeger. $367 \mathrm{p}$.

11. Kelly G. The Psychology of Personal Constructs. London : Routledge, 1992. $470 \mathrm{p}$.

12. Maslow A. Motivation and personality. New York : Harper and Row, 1987. 293 p. $416 \mathrm{p}$.

13. Rogers C.A Way of Being. Boston : Houghton Mifflin, 1980.

14. Hjelle L., Ziegler D. Personality Theories. New York : McGrawHill Publishing Co., 1992. 624 p.

15. Обгрунтування парадигми менеджмент-освіти у соціокультурній сфері. За ред. Я.М. Мартинишина. Біла Церква : Вид. Пшонківський О.В., 2017. 509 с.

16. Мартинишин Я.М., Коваленко Є.Я. Мистецтво управління й освітні технології підготовки менеджерів соціокультурної діяльності. Біла Церква : Вид. Пшонківський О. В., 2018. 374 с.

17. Мартинишин Я.М., Хлистун О.С. Ієрархія як феномен організаційної культури. Вісник Київського національного університету культури і мистецтв. Серія: Менеджмент соиіокультурної діяльності. 2019. Вип. 1. С. 7-31.

18. Сріна А.М. Статистичне моделювання та прогнозування. Київ : КНЕУ, 2011. 170 с.

Information about the author: Martynyshyn Ya. M.

Doctor of Economics, Professor, Professor at the Department of Show Business Management of the Kyiv National University of Culture and Arts 36, Eugene Konovalets str., Kyiv, 01601, Ukraine 


\section{PSYCHOLOGICAL ASPECTS OF ANDRONGO SUPPORT}

\section{Maslianikova I. V.}

\section{INTRODUCTION}

At the present stage, the adult education is actively developing and is mobile. It has consistently expanded its influence on various social and professional systems. After all, the assimilation of a new social experience by an adult is conditioned by the their activity, specific needs and personal interest. The adult is a unique holistic system that strives for selfactualization. However, it should be borne in mind that usually an adult is very cautious about himself as a student. An adult prefers such an organization of the educational process in which other people will need her experience. In addition, age-related psychophysiological changes, personality traits that have become more acute with age, and psychological barriers that can be caused by a variety of reasons hinder the acquisition of new knowledge and practical skills. All this can negatively affect both the procedural and the effective side of the adult learning process. Thus, having a certain experience and subjective position in education, an adult knows why she is learning and how he will be able to use the knowledge, skills and abilities in his personal and professional life. Therefore, the quality and practical orientation of educational services comes to the fore for an adult. Therefore, for maximum efficiency of the educational process should be included in the organization of psychological support. Psychological support has a positive impact on the prevention of difficulties during learning and solutions problems that have already arisen and interfere with the successful implementation of the educational process of adults.

\section{The concept of support in modern psychological and pedagogical science}

Actualization of scientific approaches to psychological support aims to reveal the basic semantic units, to analyze the diversity of movement and focus, to consider different types, indicators and criteria. 
Etymologically, the concept of support is close in value to the promotion, the total movement by one person to another to overcome difficulties.

"To accompany, as indicated in the "Explanatory dictionary of the Russian language" edited by D.N. Ushakov, means to go, to go with someone as a companion or guide" . In the dictionary V.I. Dal support is interpreted as an action on the verb "to accompany", that is, "to go along with the purpose, to conduct, follow"2. If we turn to the common understanding of the word support, it means the meeting of two people and the joint passage of a common segment of the pathway, and to accompanymeans to pass with someone part of his pathway. In an escort situation, there are three main components: the one who is accompanied; the one who accompanies; and the path they travel together. We can say that we are talking about the joint existence of people in a certain period of human life. Accompanying (satellite) appears as a person, protects and helps the traveler on the road to cope with the variability of the path.

The concept of "support" V. Slyusarev used to refer not prescriptive forms of psychological assistance aimed "not merely to enhance or improve, and to development and self-development of consciousness of the person", the help that triggers the mechanisms of self-development and activates its own human resources ${ }^{3}$. Many researchers note that support "involves the maintenance of naturally developed reactions, processes of personality". Moreover, successfully organized psychological support opens up prospects for personal growth, helps a person to enter the "zone of development", which is not yet available to him.

The analysis of other interpretations of psychological support in the studies of various authors showed their content:

$\checkmark$ psychological support as a system of professional activity of a psychologist aimed at understanding the socio-psychological conditions for successful learning and psychological development of the child in situations of school interaction (M. R. Bityanova);

$\checkmark$ psychological support as a multidisciplinary method which ensures the unity of the efforts of teachers, psychologists, social and medical workers, and consists in the formation of the orientation field of

\footnotetext{
${ }^{1}$ Ушаков Д.Н. Толковый словарь русского языка. М.: ООО «Издательство АСТ», 2008. 1054 с.

2 Даль В.І. Толковый словарь русского языка. Современное написание. М.: АСТ, 2010. 815 с.

${ }^{3}$ Слюсарев Ю.В. Психологическое сопровождение как фактор активизации саморазвития личности: Автореф. дис. ... канд. психол. наук: 19.00.01; Санкт-Петербург. гос. ун-т. С.Пб., 1992. 16 с.
} 
development, where responsibility for the activity shall be the subject of development (E. I. Kazakova);

$\checkmark$ psychological support as the position of the psychologist in relation to the subjects of interaction where the main principles are inclusion, participation, welfare (T.N. Chirkova).

In recent years, the paradigm of support in modern psychological science is becoming particularly popular. Many authors recognize the existence of the specifics of the implementation of psychological support in different types of educational institutions, due to different approaches to educational challenges, opportunities and objectives, other characteristics specific to educational environments (M. R. Bityanova, T. Zemskaya, E.A. Kozyrev, V.E. Phelan, T.I. Mote, V. Rodionova, M. Stepnicka etc.). The authors consider the accompanying activity of each specialist from the standpoint of creating conditions for ensuring the educational process in accordance with the individual capabilities of each participant of educational activities, the development of his personality. A number of principles that include regulates psychological support how the interaction of the accompanying person is organized:

$\checkmark$ the priority of interests accompanied,

$\checkmark$ the continuity, multidisciplinary approach,

$\checkmark$ formation of a unified attitude to the participant of educational activities on the part of all participants of support,

$\checkmark$ constant information exchange between them with a clear understanding of their part of the activities and lines of interaction.

According to the direction of work psychological and pedagogical support includes different approaches:

The first is support-cooperation, which envisages joint planning specialist performs a support and participant in the educational activities, analysis, creativity, reflection requires the actions required for the following self-overcoming of the problems that have arisen, that is, to exercise personal responsibility, creativity, unique qualities of the participant of educational activity.

The Second is support-initiation, known since the time of Socrates, the essence of which was perfectly formulated by M. Montessori: "Help me to do it myself, doing nothing for me, direct in the right direction, push to a decision, and I will do everything else myself". Organizing support-initiation, the participant of support creates the conditions for 
free, individual, independent choice of ways and means of solving educational problems for the participant of educational targets. Thus, the participants of educational activities realize their personal creative potential and at the same time enrich, develop, while maintaining its individual originality.

The third is support-warning, when the specificity of age, limited individual experience of the participant of educational activity acquires special importance. Ahead of undesirable events, predicting their possible adverse development, participant support in the framework of supportprevention involves missteps party educational activity and, thereby, helps to choose appropriate solutions, taking into account the problematic educational situation. Support-warning becomes useful and valuable if its content and form, unobtrusive and delicate, modern, psychologically and pedagogically competent, targeted, measured, and most importantly, if accompanied by a warning in all cases fully meets its developmental and remedial purpose, working for the future ${ }^{4}$.

Analysis of the literature showed that psychological and pedagogical support still does not have a complete holistic scientific description, there are signs that relate to various branches of scientific knowledge: pedagogy, social pedagogy, psychology, sociology. It is identified with the methods and forms of education, such a position of participants of educational activities and support of participants as "free communication", "comradeship" "inner mood" (N. Krylova).

Scientific sources indicate that today there are a number of reasons for the classification of types of psychological support, including the form of work, focus, subject and object of psychological support. Analysis of the psychological literature (G. Bardier, M. R. Bityanova, Ivan Romazan, T. Cherednikov, T.I. Chirkova, etc.) have shown that party support needs allocation of parameters for assessing the effectiveness of its system. So, Y.P. Fedorov, analyzing allocation problems performance criteria of the model of psychological support, concluded that they presented two groups of indicators: from the specialist, and the learning environment. At the same time, the author points to the fuzziness of the criteria, which complicate their practical application, their further specification, the

\footnotetext{
${ }^{4}$ Психолого-педагогічний супровід і підтримка в умовах модернізації освітньо-виховного простору: [Електронний ресурс] // Режим доступу: URL:http://osvita.ua/school/upbring/1334
} 
implementation of which is possible due to the allocation of normative guidelines of each age ${ }^{5}$.

In General, psychological support is a concept quite common in working with different categories of persons, and actually this type of psychological activity should be distinguished from other types of assistance in difficult situations, such as: medical rehabilitation, psychological and pedagogical rehabilitation, social rehabilitation, psychological rehabilitation, psychological correction, psychological therapy, psychological counseling, psychological prevention, psychological support, psychological adaptation.

Analysis of the psychological literature suggests that today support is a special form of prolonged social and psychological assistance. Unlike the correction it suggests is not "corrective and restructuring", and search for hidden resources of human development, reliance on their own capabilities and on establishing psychological conditions for restoring ties with the human world. In our opinion, the ideas of psychological support to the greatest extent correspond to the progressive ideas of national psychology, pedagogy and social work. In each case, the tasks of support are determined by the characteristics of the person who is provided with psychological assistance, and the situation in which the support is carried out. An essential characteristic of psychological support is the creation of conditions for the transition of the individual to self-help. Conventionally, we can say that in the process of psychological support specialist creates the conditions and provides the necessary and sufficient (but in any case not excessive) support for the transition from the position of "I can not" to the position of "I can cope with their life difficulties".

\section{Psychological foundations of adult education}

In adult education, from a psychological point of view, a high degree of freedom and choice of all parameters of the educational process (goals, motives, forms, methods, and control) is realized. In this case, the teacher plays the role of a mentor, a consultant, helping an adult who is learning. It is the recognition of the leading role of an adult student that was taken by teachers and psychologists as the basis for understanding the specifics of adult education. Adult education involves the rational distribution of

\footnotetext{
5 Федорова Ю.П. Психологическое сопровождение личностного развития младших школьников в частной школе: Автореф. дис... канд. психол. наук: 19.00.07; Вятский государственный гуманитарный университет. Курск, 2003. 18 с.
} 
periods of study and work of a person throughout her life, the acquisition of the necessary knowledge, skills, qualities, personal orientations as the need for them.

So, the psychological foundations of adult education are as follows:

$\checkmark$ an adult who learns has a leading role in the learning process;

$\checkmark$ an adult student seeks self-realization and independence;

$\checkmark$ an adult student already has life (social, professional, personal) experience that can be used as an important source of learning both to him and his colleagues;

$\checkmark$ an adult learns to solve an important life problem and achieve a specific goal;

$\checkmark$ an adult learner expects an urgent received during the training of knowledge, skills and qualities;

$\checkmark$ adult learning activity is largely due to temporary, social, professional factors limiting or contributing to the learning process;

$\checkmark$ adult learning process is organized as a joint activity of the student and the teacher at all stages: planning, implementation, evaluation and, to a certain extent, correction ${ }^{6}$.

On this basis, in adult education, the leading role in the organization of the learning process at all stages belongs to the adult, since he is an equal subject of the learning process.

The adult student takes an active part in the preparation and implementation of the training program and at the same time carries out joint activities with the teacher. Defining in this process is the interaction between the teacher and the adult student.

The main purpose of adult education is to develop critical and creative thinking. In this regard, the key provisions can be formulated in this way:

$\checkmark$ an adult is a social being who thinks critically and is capable of learning;

$\checkmark$ critical and creative types of thinking are the most acceptable and contribute to adult development;

$\checkmark$ the combination of collective learning and self-learning fully contributes to the development of critical and creative thinking;

\footnotetext{
${ }^{6}$ Професійне навчання дорослого населення: теоретико-методологічні засади: [монографія] / авт. кол.: Ничкало Н.Г., Радкевич В.О., Щербак О.І., Дорошенко Н.І., Василенко О.В., Скульська В.С. Кіровоград: Імекс-ЛТД, 2013. С. 50-63.
} 
$\checkmark$ adult education is not aimed at the transfer of ready-made knowledge, but at their selection, synthesis and open dialogue between adult students and teachers.

Given the above, the characteristics of adult education are:

$\checkmark$ non-prescriptive nature of training;

$\checkmark$ problem-setting and acquisition of necessary knowledge;

$\checkmark$ orientation training on results in solving problems;

$\checkmark$ communication with practice and verification of learning outcomes;

$\checkmark$ constant discussion of the content, forms and methods of training in the study group;

$\checkmark$ taking responsibility for the learning process by all group members and the teacher; members ${ }^{7}$.

$\checkmark$ learning outcomes assessment process involving all group

Accordingly, adult students should be able to listen to each other, respect each other's opinions and feelings, critically perceive the thoughts expressed, ask correct questions and seek to share the opinion of the other. Dialogue assumes equality between the members of the study group, frankness, gullibility, respect each other, mutual respect, integration of thinking and learning when the adult learner is in control of their thinking and learning, unlike learning situation in which the individual mind just adapts to the authority or the experience of others.

After all, from the point of view of andragogy, learning adults have a deep need for independence, self-government, a leading role in the learning process. The task of the teacher is to encourage and support the development of the adult learner. The main characteristic of the educational process is an independent definition of adult learner parameters of learning, knowledge acquisition, formation of skills, skills, necessary qualities. In this case, an adult to the extent of his growth accumulates his own experience, which can be used as a source of learning. Accordingly, the main forms of learning are experiments, discussions, solving specific problems.

The readiness of adult students to learn is determined by their need to acquire knowledge, skills and qualities to solve specific life problems. In this case, the task of the teacher is to provide students with the necessary

\footnotetext{
${ }^{7}$ Професійне навчання дорослого населення: теоретико-методологічні засади: [монографія] / авт. кол.: Ничкало Н.Г., Радкевич В.О., Щербак О.І., Дорошенко Н.І., Василенко О.В., Скульська В.Є. Кіровоград: Імекс-ЛТД, 2013. С. 50-63.
} 
methods and criteria, to help them in the selection of the necessary knowledge, skills and qualities. In this regard, the educational process is based on the individualization of learning and joint activities of the teacher and adult students.

However, it should be borne in mind that with age, it becomes more difficult for a person to be involved in educational processes through certain internal barriers (Fig. 1).

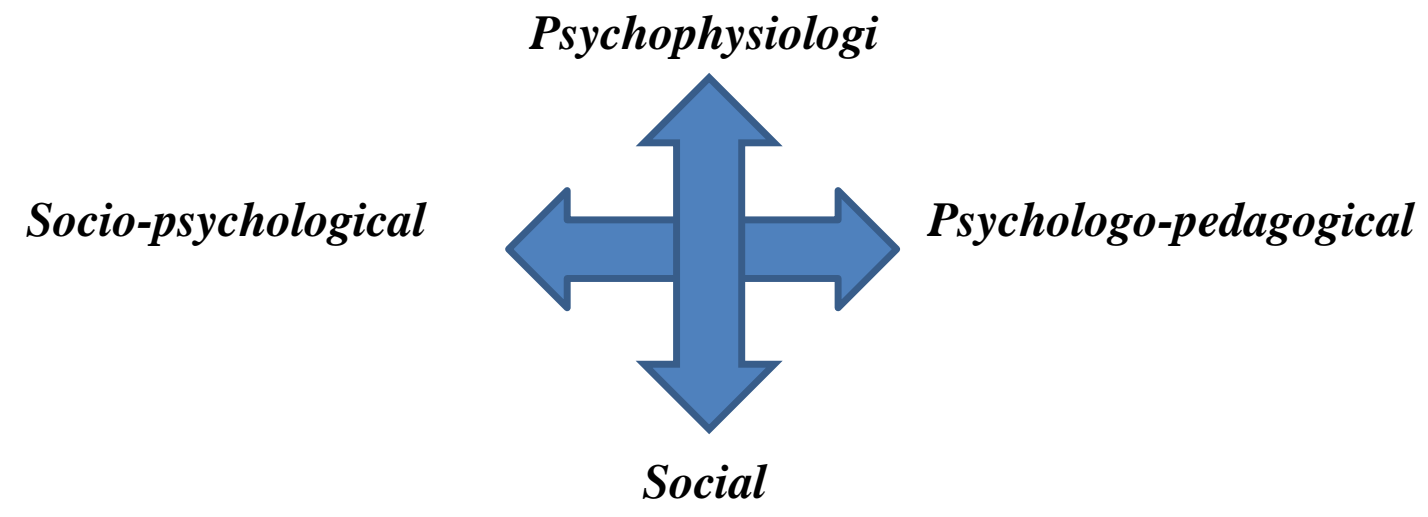

\section{Fig. 1. Internal barriers to the inclusion of adults in educational processes}

The essence of internal barriers is as follows:

1. Psychophysiologic. Some adults have an internal barrier to their ability to learn. This barrier is to some extent based on the myth of the decline with age of the ability to perceive, remember, reproduce educational information. However, scientists have proved that it is possible to study successfully at any age, but in different periods of life, different memory functions, types of attention come to the fore, motivation changes, but in General, an adult is always able to acquire appropriate individual ways of optimal work with information. However, the motivation to learn must be sustainable.

2. Socio-psychological. Some adults are uncomfortable in the position of a student. This is especially true for those who hold administrative positions. Psychologically, they are not ready to become an "object" of pedagogical influence.

3. Social. Increased requirements for a new level of education on the part of society lead to the fact that the continuation of education by an adult is impractical. 
4. Psychological-pedagogical. Installation aborted in the adult, the need for education throughout life. The lack of awareness about own abilities, peculiarities of perception and assimilation of educational material, information needs can hinder the continuity of education. After all, a person may simply not be aware of the forms of adult education ${ }^{8}$.

In this regard, there is an extremely important need for psychological support during adult education.

\section{The essence of psycho-androngo support}

Speaking about psychological support of adults, it seems to us fundamentally important to clarify the terminological apparatus, which will be used in this context. Consider how the term "support" is interpreted in the scientific psychological and pedagogical literature.

Thus, from the standpoint of a systematic approach, in which human development is understood as the choice of ways to solve a problem situation and the development of the subject of certain innovations, support acts as a special assistance to the subject, aimed at preventing and overcoming the problems of its development. Support in this situation is aimed at revealing the inner potential of the individual.

Kazakova E.I. defines maintenance as a method that provides conditions for the subject of development to make optimal decisions on various situations of life choice (ie, many problematic situations) ${ }^{9}$.

Some researchers (L.S. Alekseeva, I.V. Romazan, T.S. Cherednikova, etc.) note that support involves the support of mental development of the individual, including opens up prospects for personal growth ${ }^{10}$.

Based on the provisions of the personality-oriented approach, Zeer E.F. interprets psychological support as a holistic process of study, formation, development and correction of professional formation of the individual. At the same time, the accompanied person is not provided with ready-made recipes for solving his problems, but takes measures that set him up to perform the necessary actions in this situation, to make the best decision for him.

\footnotetext{
${ }^{8}$ Сучасні технології освіти дорослих: посіб. / авт. кол.: Л.Б. Лук'янова, О.В. Аніщенко, Л.Є. Сігаєва, С.В. Зінченко, О.В. Баніт, Н.І. Дорошенко. - Кіровоград: Імекс-ЛТД, 2013. С. 105-118.

9 Бизяева А.А. Психология думающего учителя. Педагогическая рефлексия. Изд-во: ПГПИ им. С.М. Кирова, 2004. 216 с.

${ }_{10}$ Адольф В.А., Ильина Н.Ф. Инновационная деятельность педагога в процессе его профессионального становления / Агентство образования адм. Краснояр. края, Краснояр. краев. ин-т повышения квалификации и проф. переподгот. работников образования. Красноярск: Поликом, 2007. $190 \mathrm{c}$.
} 
According to Slusarev Y.V., under the accompaniment is understood as a specially organized process, aimed at creating a "transitional space" a safe environment in which it becomes possible the exit of the individual from alienation (from themselves, other people, activities, the world at large), the reconstruction of its subjective image of the world and reconnect with themselves, others, activities ${ }^{11}$.

Vasilkova T. A. the main purpose of psycho-androge support, put forward "to maintain an optimal level of activity as a psychological basis of professional and social mobility", which should ensure the inclusion of people in the educational activity taking into account its psychological potential ${ }^{12}$.

After analyzing all of the above and taking into account the specificity of theory and methods of adult learning, we propose to consider psychological support adult learning as a system of measures organized by tutor in virtual or real educational environment aimed at creating favorable conditions to prevent possible difficulties or overcome those that have arisen, to stimulate private resources adult student to individual educational search.

We believe that in the educational activities of adult students psychological support should be carried out at the group and individual levels, and consists in the organization:

1. increase of educational and professional motivation;

2. increased mental and physical activity;

3. productive communication with all subjects of training (colleagues, tutor/coach/teacher);

4. forecasting, planning, analysis, self-reflection, self-assessment of own educational activities;

5. realization of personal and creative potential during training;

6. getting rid of negative emotions, fatigue, creating a positive emotional atmosphere.

The organization of educational activities of adults does not provide a person who is authorized to provide psychological support to students, based on the above understanding. However, not providing psychological

\footnotetext{
11 Адольф В.А., Ильина Н.Ф. Инновационная деятельность педагога в процессе его профессионального становления / Агентство образования адм. Краснояр. края, Краснояр. краев. ин-т повышения квалификации и проф. переподгот. работников образования. Красноярск: Поликом, 2007. $190 \mathrm{c}$.

12 Василькова Т.А. Основы андрагогики: учебное пособие. М.: КНОРУС. 2009. 256 с.
} 
support to adult students significantly affects the quality of educational services and the learning process itself. Ignoring the needs of participants in educational activities leads to all sorts of misunderstandings, psychological stress, reduces motivation to learn, creates conflict situations and the like. Therefore, if there is a demand for psychological support provides tutor, coach or teacher during training sessions and outside them.

\section{The implementation of psycho-adragon support in practice}

Let us proceed to the consideration of the above outlined components of psychological support of adult students in practice.

Motivation is responsible for the direction of educational activities, the intensity and duration of preservation of its basic parameters. It is formed in connection with the development of worldview, General, individual and special abilities and awareness of the individual's place in life. Motivation is complex, contradictory and variable.

There are various motivational conditions: interests, desires, aspirations, intentions, passions, attitudes (semantic, target, operational). By making a purposeful impact on the motivational state of the individual, you can influence the motivation to learn and develop.

Thus, the psychological problems of adult students, which can negatively affect the learning motivation, are manifested in fear of taking responsibility for learning, unwillingness to change the usual stable position, doubt of their abilities, fear of showing incompetence, inability to learn or be worse than others. Exercises aimed at presenting oneself as a professional in a certain field of knowledge will help to stabilize one's own professional abilities. Exercise "My childhood dream" is recommended for the beginning of training sessions, in order to meet the group members. Its implementation is that everyone writes on a piece of paper who he wanted to be as a child (actress, doctor, teacher, astronaut, etc.). Tutor (coach, teacher) collects all the records in the hat. Next, participants take turns not looking to get someone's childhood dream and voice it. All together try to slap this person and then listen to a short story of the owner of this dreamwhy it was wanted to become this specialist, for example, a doctor, what he liked in this profession, a person eventually chose this profession. Another exercise "Provocateur-professional" can be carried out within training meetings, when participants already have an idea about each other and can not only present their profession, but also to defend their professional 
opportunities. The participants split into dev groups: some of them are provocateurs, and other professionals. The task of "professionals" is to tell about their professional activities in 3 minutes. Forth the next 3 minutes "provocateurs" ask such questions: 1. Why do you do it? 2. Why do you do it this way? Questions are asked several times to hear reasoned answers about the motives of their own professional activities, especially its implementation, professional opportunities and the like. The exercise is useful for both groups of participants and contributes to the stabilization of professional motivation, awareness of their own professional experience, develops interest in learning.

One of the most difficult problems in adults in the transition from professional to educational activities, the problem of re-motivation - with motivation to work motivation to study. At the stage of transition from professional activity to educational one should pay the greatest attention. Since most of the learning skills in adulthood are lost, a special adaptation period is needed for the restructuring of psychological subsystems for a new activity. Taking into account the peculiarities of adult education, adaptation should be managed, special and intensive. A means of adaptation can be a clarifying professional orientation in the framework of training. Here, the appropriate to get acquainted with professiograme future activities, qualification requirements, future growth, typical working conditions, with the demand for a new profession in the labour market etc.

With age as a negative phenomenon, scientists note that the processes of perception, memory, thinking in an adult are not as productive as in a child or teenager. In this regard, of paramount importance are the methods, techniques and methods of training, contributing to both the increase in mental and physical activity, as well as to maintain their optimal level for learning. To this end, the tutor (coach, teacher) should be used at the beginning of classes, as well as in the middle of training exercises aimed at increasing brain activity, synchronization of hemispheres, improving mental activity, improving memory and attention, facilitating the process of reading and writing. These can be the following exercises. Exercise "Ears" is aimed at energizing the brain. Its execution is to straighten and stretch the outer edge of each ear with the same hand in the direction up and out from the top to the ear lobe (five times) and massage the ear. Exercise "Flashlights" aims to promote interhemispheric interaction, arbitrariness and self-control of mental functions. Its implementation 
involves the following sequence of actions: put hands on the table; one balled in a fist, the other lies on the table with his palm; at the same time change the position of the hand (if right fist and left hand palm, then change to the right - hand, left - fist, and so on). Another of the effective exercises on this list is called "Fist- edge-palm".
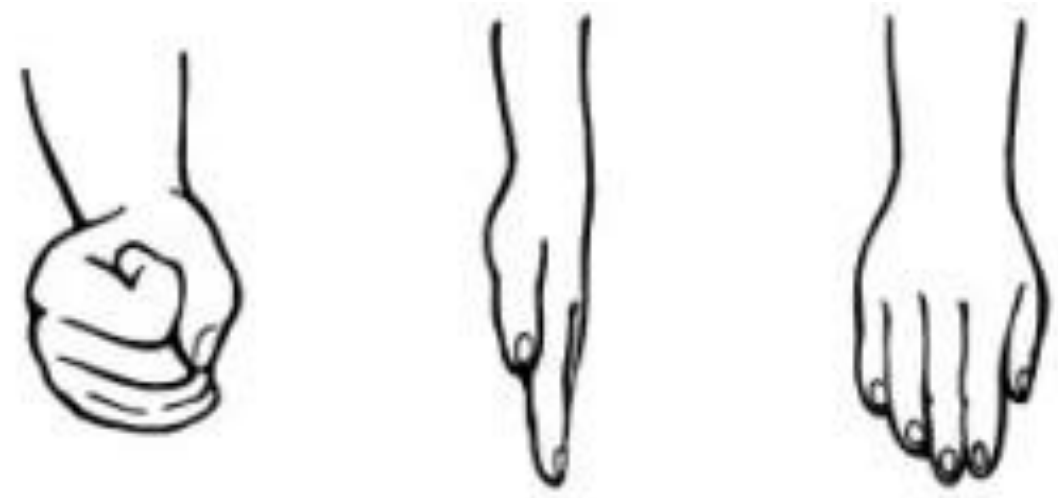

Fig. 2. Hand position during exercise "Fist- edge-palm"

Tutor (trainer) shows participants three-position palm on the table, consistently replacing each other: the open palm on the table, hand clenched, the palm squarely on the table. First, the exercise is performed together with the tutor, then independently:

1) right hand palm;

2) left hand palm;

3) with both hands at the same time.

It is important to change the pace of execution, then accelerating, then slowing it down.

Speaking about the psychological features of mental activity of an adult student, it should also be emphasized that with age, different functions become more interconnected, coordinated, integrated into a single whole, which allows a person to compensate for the shortcomings in the development of one function (for example, memory) due to the higher development of another (for example, thinking). For this purpose, when teaching adult students it is appropriate to use such teaching methods as: analysis of problem and practical situations, brainstorming, association method, business games, group discussions and others.

Organization of interaction and effective communication is the next point of adult education, which requires psychological support. Due to 
different circumstances, the communication skills of adult students who find themselves in the same learning space may be different. Not everyone equally aptly manages to formulate their own opinion, give feedback or even raise a question. Tutor (coach, teacher) should direct their efforts to ensure that the essence of the dialogue between adult students was to recognize the uniqueness of each other by each partner, their mutual equality in relation to each other, differences and originality of perspective, the orientation of each to the understanding and active interpretation of his perspective partner, waiting for the answer and its glorification in its own expression and mutual enrichment of the dialogue partners. The beginning of such interaction can be exercises aimed at training the speech apparatus, for example, with the help of pronouncing all of us known tongue twisters.

Also accurate can be exercises to explore, such as "Snowball of name", which is to be called by one word and his name one letter (dark Dmitry) continue to pass the torch, where the next party is already talking of the previous phrase and its etc. Along with this, you can use exercises that contribute to the ability to listen and respect for the interlocutor.

This can be an exercise "Communication options". Participants are divided into pairs and take turns using the following communication options: synchronous conversation, ignoring, back-to-back, active listening. Time use every option communication-30 sec. The topic of conversation can be any, the main thing to make it clear to the participants how important it is to be able to listen and respect the communication partner.

Speaking about the psychological support of adult learning, forecasting, planning, analysis, self-reflection and self-evaluation of their own learning activities, also requires special attention. First of all, the importance of the organizational aspects of learning process such as: creating a shared email address, social network, exchange contacts, selection of the responsible person in the group, and the like, to facilitate the timely transfer of information.

The tutor (coach, teacher) should pay attention to the clear articulation of educational tasks and requirements for their implementation, to give clear criteria for assessing educational achievements available to all participants in the educational process. Obligatory moment for adult students have the opportunity not only to keep records in notebooks, but also photo and video surveillance, the use of a dictaphone in order to better 
assimilate educational information. In addition, in the context of the above, it is useful to use the method of working groups in the classroom of adult students, where it is possible to predict, plan and evaluate educational achievements. It is also important to recommend the tutor (coach, teacher) to evaluate the educational results of other participants and their own achievements and to argue your answer based on the criteria: completeness, correctness, originality and the like.

Very important during the educational activities of adult students is the realization of their personal and creative potential. Adult students have a lot of experience-professional, personal, domestic. With this in mind, learning tasks should be designed to take into account the well-known David Kolb learning model, which is based on the gradual formation of mental actions. This theory involves a learning cycle that consists of 4 different stages and 4 different learning styles:

1) experience is the property of the new or a new interpretation of the old;

2) analysis/reflection - comprehension of experience;

3) theory - formation of theoretical models;

4) practice - active experimentation, the use of new experience.

At the same time, it will be appropriate to use the tutor (coach, teacher) during the training method of creative projects (individual or group), when adult students have the opportunity to construct their own ideas, originally issue them taking into account the creative approach and technical capabilities and voice them, in order to receive feedback from their colleagues.

The emotional component of the educational process is of particular importance, including when it comes to adult students. Given the conditions of the present, adults are constantly under the influence of stress factors, are in conflict situations, often experiencing fatigue, negative emotions, which leads to emotional exhaustion. Being in the classroom for an adult is not quite a standard situation, so emotional stress can not be avoided. To this end, it is advisable to carry out exercises aimed at relaxing and getting rid of negative emotions.

Among the list of such exercise "Algae", its implementation involves the slow movement of the plant, which pushes the water. Exercise can be done with both open and closed eyes. Lead time up to 3 minutes. The next exercise is aimed at relaxing the whole body is called "Twisting". During 
its execution, the hands are along the body, slow movements to the left and right resemble a spiral. Exercise "Annoying fly" aims to relieve tension in the muscles of the face. The participant should imagine that came annoying insect that falls directly on the nose. The task without the help of hands to drive it away. Should wrinkling nose, make as many wrinkles in your nose as you need to twist nose - up, in different sides. After relaxing one part of the face, you can move on to the next forehead, chin and others. Exercise is done to obtain a pleasant relaxing feelings. Such exercises can be used by the tutor (coach, teacher) before the start of training sessions and in between.

Further ways of improving approaches to the implementation of psychological support as a system of professional training of adults provide for further clear development of the concept of work aimed at creating the most favorable conditions for the comprehensive development and training of adults in various educational situations of micro-and macro-social interaction.

\section{CONCLUSIONS}

Summarizing the above, we can state the following. The analysis of scientific literature on this problem showed sufficient knowledge of pedagogical aspects of the theory and methodology of adult education. At the same time requires further study of the psychological aspect of adult education, namely androgynous support. In the presence of demand for this key aspect of educational activity, science has not developed a holistic view of the content, especially the implementation of psychological support of adult education and the competent person who is responsible for its qualitative implementation. Based on the practical experience of interaction with adults in the educational space, the author gave a subjective view of the psychological characteristics of the organization of androgynous support. Of course, the materials given in the article do not exhaust the whole essence of the problem of androgynous support, which indicates the need for further research in this direction.

\section{SUMMARY}

The article relates to the problems of adult education and is devoted to the issue of psychological support of adult students. Practical experience has shown that psychological support is quite an important component of 
adult education, which directly affects the quality of educational services to adult students. However, it was found that neither in the theoretical nor in the practical aspect of adult education has a holistic view of androgynous support, there is no single interpretation of this concept, and most importantly - has no clear understanding of the specialist who should implement it. The author analyzed various approaches to understanding the concept of "psychological support" and offered his own vision, which is based on the psychological characteristics of adult students. Based on practical experience in working with adult students it was pointed to the main components of psychological support of adult education. The psychological support should include: increase of educational and professional motivation; increased mental and physical activity; organization of effective communication with all subjects of training (colleagues, tutor/coach/teacher); assistance in forecasting, planning, analysis, self-reflection and self-assessment of own learning activities; assistance in realization of personal and creative potential of adult students; creating a positive emotional atmosphere during training and getting rid of negative emotions. Psychological support of adult education should occur both at the group and individual levels. It should be conducted by the appropriate specialist - teacher, coach, tutor, coach, i.e. competent person in accordance with the purpose of training. Given the above, it should be noted that the issue of psychological support of adult education continues to be quite an urgent problem that requires further study and development both in theoretical and practical terms.

\section{REFERENCES}

1. Dal' V.I. Tolkovyj slovar' russkogo yazyka. Sovremennoe napisanie. M.: AST, 2010. $815 \mathrm{~s}$.

2. Adol'f V.A., Il'ina N.F. Innovacionnaya deyatel'nost' pedagoga v processe ego professional'nogo stanovleniya. Krasnoyarsk: Polikom, 2007. $190 \mathrm{~s}$.

3. Bizyaeva A.A. Psihologiya dumayushchego uchitelya. Pedagogicheskaya refleksiya. Izd-vo: PGPI im. S.M. Kirova, 2004. 216 s.

4. Vasil'kova T.A. Osnovy andragogiki: uchebnoe posobie. M.: KNORUS. 2009. $256 \mathrm{~s}$.

5. Lipskij I.A. Social'naya pedagogika. M.: Dashkov i K., 2017. 280 s. 
6. Psihologo-pedagogichnij suprovid i pidtrimka v umovah modernizaciï osvitn'o-vihovnogo prostoru: [Elektronnij resurs] // Rezhim dostupu: URL:http://osvita.ua/school/upbring/1334

7. Profesijne navchannya doroslogo naselennya: teoretikometodologichni zasadi: [monografiya] / avt. kol.: Nichkalo N.G., Radkevich V. O., SHCHerbak O. I., Doroshenko N.I., Vasilenko O.V., Skul's'ka V. C. Kirovograd: Imeks-LTD, 2013. S.50-63.

8. Slyusarev YU.V. Psihologicheskoe soprovozhdenie kak faktor aktivizacii samorazvitiya lichnosti: Avtoref. dis. ... kand. psihol. nauk: 19.00.01; Sankt-Peterburg. gos. un-t. S.Pb., 1992. 16 s.

9. Suchasni tekhnologiï osviti doroslih: posib. / avt. kol.: L.B. Luk'yanova, O.V. Anishchenko, L.Ye. Sigaєva, S.V. Zinchenko, O.V. Banit, N. I. Doroshenko. Kirovograd: Imeks-LTD, 2013. S. 105-118.

10. Ushakov D.N. Tolkovyj slovar' russkogo yazyka. M.: OOO “Izdatel'stvo AST", 2008. 1054 s.

11. Fedorova Yu.P. Psihologicheskoe soprovozhdenie lichnostnogo razvitiya mladshih shkol'nikov $\mathrm{v}$ chastnoj shkole: Avtoref.dis... kand. psihol.nauk: 19.00.07; Vyatskij gosudarstvennyj gumanitarnyj universitet. Kursk, 2003. 18 s.

\section{Information about the authors:} Maslianikova I. V.

Candidate of Psychological Sciences, Associate Professor, Associate Professor at the Department of Psychology and Pedagogy of the Educational and Scientific Humanitarian Institute of the V. I. Vernadsky Taurida National University 33, Ivana Kydri str., Kyiv, 01042, Ukraine 


\section{THE IMPACT OF DOMESTIC VIOLENCE ON THE PERSONALITY'S DEVELOPMENT OF THE CHILD}

\section{Mitina S. V.}

\section{INTRODUCTION}

The actual problem of Ukrainian society is the overcoming and prevention of any manifestations of violence against children. The statistics show that the largest number of offenses against the person carries out precisely in the sphere of family relations, herewith about $95 \%$ of victims of domestic violence are women and children. Therefore, the problem of domestic violence often equates with the problem of domestic violence against women and minors. One third of children in Ukraine experience the domestic violence each year, it is important to accent that the childrenvictims of domestic violence commit the suicide 10 times more likely their peers. According to official data of the Ministry of Social Policy, $65 \%$ of children in Ukraine once abused, and $45 \%$ of children believe that they have experienced the psychological abuse ${ }^{1}$.

According to social studies, it is possible to state that the violence in the Ukrainian family is quite common: $44 \%$ of the Ukrainian population suffered from domestic violence throughout his life moreover, $30 \%$ of population is been abused in childhood. About half of those who is been abused as a child experienced the violence in adulthood. However, it is important to accent that the official statistics on domestic violence do not reflect the real picture, whereas the most of victims do not seek help from the police.

The situation of domestic violence greatly affects the physical and mental state of children. In $90 \%$ of cases children are witnesses by the scenes of violence, which causes them fear and frustration. Some children do not express any reaction to domestic violence, but as N.Y. Maximova notes, if there is violence, the psyche of the child always suffers. Moreover, in the case of maternal abuse, the child abuse is a possible consequence ${ }^{2}$.

\footnotetext{
${ }^{1}$ Державна доповідь про становище дітей в Україні «Реалізація конвенції ООН права дитини в Україні: досягнення, проблеми, перспективи» (за період 2009-2016 р.р.). Київ: Міністерство соціальної політики України, 2016. С. 51.

${ }^{2}$ Максимова Н.Ю. Психологія соціальної роботи із проблемними сім'ями. Київ: ВПЦ «Київський університет», 2017. С. 320.
} 
A significant part of families without state support is not able to fulfill their main functions, in particular to ensure the proper well-being and upbringing of the children. The worst thing is that the scope of domestic violence goes beyond the home: the children who suffer from domestic violence often commit the violent acts against their peers. The domestic violence, the child abuse leads to the formation of certain personality disorders, which provoke the deviant behavior in their future lives. Without overcoming this pernicious phenomenon, it is impossible to create conditions for the full development of the child's personality and to prevent further maladaptation of the minors.

\section{The causes of domestic violence against a child, its types and forms of manifestation}

The family violence is a complex phenomenon and has different forms and features, but the essence of the violence is the same. Domestic violence is an act that seeks to cause moral, physical or mental harm to another family member's health. Unlike most other types of violence, the domestic violence is always accompanied by coercion and control, and not only by physical but always psychological pressure. The most acute problem is domestic violence against children. The vulnerability of children to violence is explained by their physical, psychological and social immaturity, as well as their dependent position on adults.

It should be noted that the problem of domestic violence is multidisciplinary and various specialists study it. The representatives of different scientific schools and fields explain the violence, its causes, types and dynamics in accordance with their basic theoretical views. The scientists-lawyers study the problem of domestic violence in the context of the analysis of crimes committed in the sphere of family-domestic relations (A.G. Strelchenko, A.A. Sushchenko, L. Sukmanovsky and others). M.O. Mintz, A.M. Fesenko noted that domestic violence is a form of deviant behavior. The authors emphasize that, in addition to the aggressor, the victims of domestic violence are mainly women and minors ${ }^{3}$.

The punishment of the child, as a false method of correction of unwanted behavior, in a pedagogical context is considered by L. Begheza,

\footnotetext{
${ }^{3}$ Мінц М.О., Фесенко А.М. Насильство в сім’ї як фактор соціальних девіацій. Міжнародне періодичне наукове видання. 2013. № 2 (39). С. 17.
} 
V. Alekseeva, L.P. Melnik ${ }^{4}$. However, the research of C.I. Boltivets shows that the punishment of a child provokes only the behavior disorders, destructively affects the formation of personality and creates the basis for further maladaptation of minors ${ }^{5}$.

We use the sociological, psychological and socio-psychological conceptual approaches to explain the mechanisms of domestic violence.

The sociological approach defines the violence as a sociocultural conditionality, namely the violence is a stereotype of family relationships that is accepting in this population. Also, the domestic violence is influenced by social factors (socio-economic situation of the family, unemployment of parents, poor living conditions, etc.). L.M. Sukmanovskaya believes that domestic violence against women is a consequence of gender stereotypes and that the solution of this problem lies in the plane between such spheres of public life as culture, morality and law ${ }^{6}$.

In the aspect of psychological approach (I.A. Alekseeva, I.G. Novoselsky), the violence against a child is considered as a result of negative personal life experiences of parents, "trauma of childhood", alcoholism, psychopathology, or as a symptom of a dysfunctional family with inadequate stabilization of the family system. The negative attitudes toward a child may also be seen as the result of a destructive family interaction when, regardless of the presence or absence of specific psychosomatic characteristics or behavioral characteristics, the child risks being violent. From the psychological point of view, the motives for aggressive behavior are usually unconscious ${ }^{7}$.

The socio-psychological approach considers the domestic violence as a product of socialization, the reproduction of the model of behavior, the life experience that the child has received in the family (L.O. Kondratenko, N.Yu. Maksimova, K.L. Milyutina Yu.M. Udovenko and others). The scientists have shown that the children who have experienced the violence subconsciously seek to reproduce their life experiences in adulthood because they do not know another pattern of behavior. According to

\footnotetext{
${ }^{4}$ Мельник Л.П. Насильство над дітьми як соціально-педагогічна проблема. Корекційна та соціальна педагогіка і психологія. 2013. Ч. 2. С. 135-143.

5 Болтівець С. I. Домашне насильство як підгрунтя девіантної поведінки підлітка. Практична психологія та сочіальна робота. 2009. № 10. С. 38-39.

6 Сукмановська Л.М. Домашнє насильство: дослідження актуальної проблеми сьогодення. Юридичний Вестник. № 4. 2014. С. 217.

Алексеева И.А., Новосельский И.Г. Жестокое обращение с ребенком. Причины. Последствия. Помощь. Москва: Генезис, 2005. С. 195.
} 
T Goncharova, if parents were victims of abuse or neglected in childhood, they would use the same violent methods of education for their children ${ }^{8}$.

The domestic violence, abuse and neglect of children are manifested in different forms, have some dynamics of formation and varying degrees of expression. The families where children have abused are unequal in terms of social and material well-being, as well as the degree of emotional closeness between family members. In dysfunctional families the children are less protected from psychological trauma situations. The parents in such families are often try to reduce or conceal the violence against their child. On the basis of our research we can make conclusion, that the category of children, who has gone on the streets because of the parental abuse, are not only the children from socially disadvantaged families (57\% of our study sample), but also the children from affluent families herewith most of them (65\%) experienced the different types of violence in the family, it was a major factor of their going out ${ }^{9}$.

The violence against children in the family N.Yu. Maksimova has considered within four categories. Each of these categories of abuse can lead to physical or psychological harm to the child of varying degrees, the serious physical injury, or even death.

1. Neglect - the chronic inability or unwillingness of parents to meet the basic needs of the child in care appropriate to her age: in food, clothing, living space, medical care, education, protection and upbringing. This attitude is the result of adult irresponsibility. It varies from case when the parents leave the child alone at home for several hours while they work, to cases when the child is left unattended and the parents leave for the weekends or holidays. The worst case scenario is when parents are physically present but do not do what is necessary to ensure the health, safety, mental and physical development of the child. For example, when a child is starving or kept in a cold place, when he has not the seasonappropriate clothing, the opportunities to learn, etc. The child lives in a dangerous place: open electrical outlets, medicines, alcohol and other dangerous substances are in accessible places; hot pots, kettle, fire on stove, etc. The child who is harmed by all these dangers grows with

\footnotetext{
8 Гончарова Т.В. Насильство дітей у сім’ї: умови, причини й фактори виникнення. Соціальна педагогіка: теорія та практика. 2010. № 4. С. 47-53.

${ }^{9}$ Мітіна С.В. Соціальні чинники становлення особистості бездоглядних підлітків. Вісник Київського Національного університету імені Тараса Шевченка. Київ,2013. № 1 (7). С. 75.
} 
confidence that the world is threatening to her. It undermines the basic sense of security, forms a deep distrust of others and the world in general.

2. Psychological violence. It is the type of parents' behavior, which harms the child's personal development and self-esteem. The psychological abuse involves the verbal attacks such as constant criticism, humiliation, insults, ridicule, mocking, teasing, and refusing to listen to the child. The psychological violence also includes the inability of parents to show love and support and guidance necessary for personal growth and development of the child. The psychological violence can include the verbal and non-verbal violence, which will be without words at all - to make the victim feel humiliated or keep it in the atmosphere of fear using facial expressions, poses, sights, intonations.

3. Physical violence. This category includes the physical trauma of a child, not only when there are appropriate signs (bruises, wounds, fractures), but also such varieties of physical violence when the signs cannot be detected immediately because they manifest later (for example, internal organ damage, air obstruction etc).

4. Sexual violence. This category includes all kinds of sexual activities with children, as well as forcing children to have sex with one another or to watch adult sex. The child sexual abuse and sexual exploitation is one of the gravest violations of the rights of the child. The sexual assault and sexual exploitation are equal to torture by the amount of injuries inflicted. Even if a child perceives the sensual pleasure of adult action, it is still the sexual violence ${ }^{10}$.

Usually, the child victim suffers from several types of violence at the same time. It should be noted that psychological violence is an integral part of all types of violence. Much more dangerous is the situation when the elements of sexual, physical and psychological violence are combined, and the violent acts are accompanied by threats and intimidation by the abuser. The child suffers not only from the situation itself, but also from his own helplessness, inability to seek help, which leads to depression, suicide attempts and mental disorders (neuroses, psychotic reactions, etc.).

Summarizing aforesaid we can note that there is lot of causes that influence the manifestation of domestic violence against a child. However, whatever the reasons of the violence, it always causes the negative

\footnotetext{
${ }^{10}$ Максимова Н.Ю. Психологія соціальної роботи із проблемними сім’ями. Київ. ВПЦ «Київський університет», 2017. С. 321.
} 
consequences and raises a variety of problems, both social and psychological.

\section{The psychological characteristics of children-victims of family violence}

The psychological consequences of all forms of violence against the child are the formation of distrust in adults and the world at large. The child begins to be afraid to be active and independent in the study of the outside world, and this dramatically inhibits his mental and personal development.

The disturbances in the cognitive area are often found in disorders of the language. The neurotic stuttering may result because of child abuse. The children of school age have a decrease in concentration of attention because all thoughts of the child are occupied by traumatic experiences. The child keeps a close eye on everything that happens around, as if he is in constant danger. Moreover, the danger is not only external, but also internal, because of unwanted traumatic impressions, which always pop up in the mind ${ }^{11}$.

Recall that the basis of any form of violence is psychological, emotional deprivation, rejection, which cause harm to the development of the child's personality.

The children are brought up in the absence or limitation of parental care, which leads to the special deprivation of violations in the development of personality. I. Yaroslavtseva, depending on the specifics of the deprived development, has determined the full interruption of the child's communication with the parents, identified two levels of mental deprivation: general and partial. The general mental deprivation is formed under conditions of children's home, from birth or early childhood the children were deprived of parental care. In these cases, the specific development is characterized by a gross disproportion of all aspects of the development of the child's psyche. The partial mental deprivation is characterized by the mild disharmony of personal development. This disharmony is typical to the children and teenagers from dysfunctional families who are brought up in conditions of limited parental care and in the lack of emotional connection with their parents. These children and

\footnotetext{
${ }^{11}$ Бегеза Л., Алєксєєва В. Насильство над дитиною як чинник деструктивного впливу на формування іiі особистості. Сучасна икола Украӥни. 2011. № 9. С. 47-92.
} 
teenagers have the varied negative manifestations of the mental state, however, they are shallow and mosaic and may affect certain areas of personality development ${ }^{12}$.

$\mathrm{N}$.Yu. Maximova notes that the basis of all intrapersonal conflicts of the children from dysfunctional families is in the contradictory attitude towards parents: on the one hand, the child continues to love them, and on the other, the constant feeling of failure, the vainness of their hopes for appropriate attitude of parents causes painful emotional experiences. This contradiction keeps the child in constant tension, which leads to negative consequences. The personality development can further proceed in the following directions:

1) the occurrence of self-centeredness, when the child sees other people as the means to achieve their goals;

2) the rejection of "Self-image", the emergence of a "guilt complex", when the child devalues itself, feels incapable of anything, useless;

3 ) the formation of hypersociality, when the person tries to prove his whole life that he is worthy of respect ${ }^{13}$.

The children deprived of the positive influence of the family have the violations in the development of self-awareness, the inconsistency of "Self-image". The behavior of the child from an adictive family depends on the compulsive behavior of the parents, the "Self-image" is formed as the result of search for security, the desire to preserve their own identity. The desire to keep the attention of the parents on the child is established by the codependent behavior, which is expressed in the attempt to take on the solution of family problems, the denial of their own needs. The consequence is the devaluation of feelings and the inability to express them, the inability to establish the emotional intimacy, the instability of "Self-image".

A.A.Katsero's studies show that the teenagers from dysfunctional families have the contradictory ideas about themselves, they have the low differentiation of the "Self" characteristics: the images "Self-real", "Self-past", "Self-future" are close to "Self -ideal". The representation of the teenagers themselves in this form without the influence of functionally safe family doesn't provide socially approved behavior. The image of "Self

\footnotetext{
12 Ярославцева Н.В. Система мер по оптимальному жизнеустройству детей. Работник соииальной службы. 2003. № 2. С. 25-28.

${ }_{13}$ Максимова Н.Ю. Основи психології девіантної поведінки. Київ: ПЦ «Київський університет», 2008. $439 \mathrm{c}$.
} 
-ideal" is characterized by the positive direction, but it is inherent isolation from the "Self-real", the inconsistency of the "Self-image" actual experience. The "Self-image" of the neglected teenager is transformed under the influence of contradictions with the environment, self-defense becomes the leader in the structure of "Self-image" and turns into the means of self-affirmation. Therefore, the features of the "Self-image" structures are the indication of the person's possibility to adaptation to the social conditions of his life ${ }^{14}$.

The consequence of the deprivation of the child's need for parental care and love is a distorted development of self-awareness, expressed selfdoubt, low self-esteem. For explanation of the reasons for the inadequacy of self-esteem of neglected teenagers, we should recall the notion of "working model" (theory of attachment by J. Bowlby). The "working model" includes the model of oneself and of a loved one ("Self-Other"), while the perception of oneself is determined by perception of the object of attachment. The deep memory keeps the patterns of behavior with close people who are constantly repeated in interaction with others, determining the nature of the relationship in the dyad "Self-Other". The teenagers from dysfunctional families from early childhood are deprived of stable and emotionally balanced relations with their parents, which explains the inadequacy of their self-esteem.

The lack of significant adult and unconditional acceptance of the child, the limitations of parental care, makes it necessary to adapt in children the passive attitude to life. As the result, the neglected children do not form their own values and principles, however, the conformance of behavior develops, which contributes to the assimilation of antisocial norms and values in conditions of negative microsocium. Our studies indicate the transformation of the value-semantic sphere of the neglected teenagers, indicate their inconsistency, dependence on situational influences. There is the decrease in understanding of their present, past and future ${ }^{15}$.

The reaction to the situation of chronic family distress, violence, children form negativity or passive refusal to everything that is imposed on

14 Кацеро А.О.Структура та зміст „Я”-образу у бездоглядних підлітків. Актуальні проблеми психологї. Т. VII: зб. наук. працьь Ін-ту психологї ім. Г.С. Костюка АПН Украӥни. Київ, 2005. Вип. 3. C. $148-156$.

${ }^{15}$ Мітіна С.В. Психологічні чинники становлення особистості підлітків в умовах бездоглядності. Вісник післядипломної освіти: зб. наук. праць. Київ, 2012. Вип. 8 (21). С. 256-262. 
them as the habit to imitate any activity, at the same time, the ability for systematic efforts, which is important for independent living, is not formed. The teenagers becomes accustomed to the fact that nothing depends on him, resulting in the inability to plan his life, the low understanding of his ability to cope with the problems and life difficulties.

According to the concept of K. Horney, the child's early feelings, the rejection by parents, contributes to the growth of anxiety disorders, forms the basal hostility in the child. The emotional disorders, anxiety, fears are the necessary consequence of a situation of violence. The preschoolers have fears about fabulous creatures or an uncertain feeling of anxiety. One of the typical manifestation of a child's response to violence is sleep disturbance. It manifests in the form of night terrors with awakening, nocturnal enuresis, walking in a dream. Children and adolescents who have been abused, feel helpless and grief. The depressive emotional state characterized by crying, slowing down of mental processes, complaints about pain, which appears without the reason, can also be the consequence of violence ${ }^{16}$.

The study of K.L. Milutina, N.Yu. Maksimova showed that the internal contradiction between the intensification of teenager's negative emotions associated with the fact of domestic violence and the inability to express them in communication leads to the kind of "freezing" of emotions. At the same time, the development of the emotional sphere is inhibited, the formation of empathy does not occur, a peculiar emotional dullness is formed. This leads to the fact that in future adult life, such person is not only unable to express his feelings, but also shy person will try to avoid situations related to the emotional area of life ${ }^{17}$.

The violence in family negatively affects the homeostasis in the system of child - society on the level of behavioral manifestations. The state of constant threat forms the catastrophic cognitive model of the world and the need for barriers to interacting in the form of aggressive reactions, avoidance of contact and violation of social norms. The lack of positive communication with parents predetermines the development of inadequate communication with others, when protective situations of behavior dominate in conflict situations: the inability to constructively solve the

\footnotetext{
16 Чаплінська Л.В. Проблема психологічного насильства над дітьми дошкільного віку: причини, види та наслідки. Науковий вісник Мукачівського державного університету, 2015. Випуск 1 (1). С. 125-129.

17 Максимова Н.Ю., Мілютіна К.Л. Соціально-психологічні аспекти проблеми насильства. Київ: Комітет сприяння захисту прав дітей, 2003. 344 с.
} 
problem situation, outbreaks of aggression, and desire to shift responsibility to the others. The disadaptation of the children is manifested in the loss of social orientation of feelings, distrust of the social environment, social non-contact, inability to share their social roles, to establish friendly relations ${ }^{18}$.

$\mathrm{N}$. Yu. Maximova notes that depending on the peculiarities of the child's temperament, the disturbance of his emotional state due to domestic violence begins to manifest itself in the form of the following behavioral disorders:

- the children with a strong type of nervous system exhibit aggressive behavior directed at peers, namely they try to identify with the aggressor;

- the children with a weak type of nervous system feel intense anxiety even in safe situations, they complain about fears, are afraid of fairy-tale characters and real people. The children of this type often cry, avoid peer communication, and fear the strangers ${ }^{19}$.

Thus, violations that occur as a result of violence, affect all levels of human functioning. Abused children cease to trust people, because of this their circle of communication narrows, they become closed and hostile. One of the most important consequences is inadequate self-esteem, the lack of control over the impulsiveness, the decreased ability to express oneself, the lack of trust in people, depression. The domestic violence leads to persistent personal changes that impede the child's ability to realize himself in the future.

\section{The prevention of the violence in the family in relation to the minors}

In accordance to the Law of Ukraine, the prevention and counteraction to the violence in the family is defined as the system of measures aimed to the ending of domestic violence, to providing the assistance and protection to the victim, the compensation for damage, as well as the prosecution of offenders and the changing of their behavior ${ }^{20}$.

Although the prevention of domestic violence relates to the functions of the law enforcement agencies, working with the family which has this problem, is primarily the responsibility of the social worker and the

\footnotetext{
18 Болтівець С. I. Домашне насильство як підгрунтя девіантної поведінки підлітка. Практична психологія та соичіальна робота. 2009. № 10. С. 38-39.

${ }_{19}$ Максимова Н.Ю. Психологія соціальної роботи із проблемними сім'ями. Київ: ВПЦ «Київський університет», 2017. С. 329.

20 Закон України «Про запобігання та протидію домашньому насильству» від 7 грудня 2017 року № 2229-19 [Електронний ресурс]. Режим доступу: http://zakon3.rada.gov.ua/laws/show/2229-19
} 
psychologist. This is explained by the fact that usually the assistance to such family starts with the social intervention that occur after the receiving of the police reports. The social services focus on organizing the work with families who belong to the social risk group. Actually the certain system of correctional and rehabilitation work has been developed with the families which are in the difficult situations. This system includes the various state and public organizations, the multidisciplinary centers which, within their competence, carry out the measures to prevent and overcome the domestic violence.

The analysis of the literature on this issue shows that there are the different models of work with the families aimed at assisting of the children who are the victims of violence and preventing the domestic violence. The prevention of domestic violence involves the education of the parents to interact with their children at every stage of their lives, the prenatal support programs, and education of the young parents to proper care for their children. The purpose of other models of the care is timely detection of the child maltreatment. The third model directed to assist the victims of violence and minimize the risk of recurrence in the victim's future family. The fourth model work to strengthen the family and prevent the problems. The fifth - to help at-risk families - poor families, single mothers, young parents ${ }^{21}$.

In our opinion, in order to overcome the violence against children, it is important the organization of the system of the social and psychological assistance, which envisages the complex-differentiated approach taking into account the specifics of the family, the variety of domestic violence and is aimed both at providing assistance to the child, as well as to work with each family member, in order to further prevent of manifestation of domestic violence.

It should be noted that the effectiveness of assistance depends on the possibility of receiving it at any stage of the development of family relationships and the life of the child. Therefore, the organization of social and psychological work with the family to overcoming the violence should based on the following principles: accessibility, timeliness, completeness and confidentiality of care. In situations which pose a threat to the mental or physical health of the child, the crisis management is required. First of

\footnotetext{
21 Алексеева И.А. Жестокое обращение с ребенком. Причины. Последствия. Помощь. Москва: Генезис, 2005. С. 195.
} 
all, we have in mind the following types of violence: - the experiences of physical, psychological or sexual violence and their consequences; - the acute conflicts in the family; - the emotional and behavioral disorders in the child-parent relationship that provoke the child to leave the house.

Based on the analysis of the literature and the results of our own research, we believe that the most complete version of the structure of the crisis social and psychological assistance should include: - the crisis psychological emergency telephone; - the medical and psychological assistance; - the social and legal assistance; - the self-help groups, which aim to create the socio-therapeutic environment for teens ${ }^{22}$.

In Europe, children who have been subjected to violence in the family can be admitted to the temporary residence group at the regional crisis center. At the center, children continue to attend a regular school, and maintain relationships with their friends and parents, with whom work is also underway. The task of the Crisis Center - help the family to overcome the difficult circumstances ${ }^{23}$.

The effectiveness of social and psychological work with victims of domestic violence is ensured by the availability of various forms of assistance: the helpline, the individual counseling, the family counseling and the family psychotherapy. The use of different forms of work depends on the problem and the characteristics of the family.

In 2013, La Strada-Ukraine public organization created the National Children's Hotline, which operates around the clock on a toll-free number and receives the calls on violence and ill-treatment against children ${ }^{24}$. The emergency psychological crisis telephone allows to implement the main principle - the availability and timeliness of help. With acute problems, the immediate help is required, the sooner the child receives it, the less negative consequences it may be for him. It is also important to keep in mind that the motive for seeking the help from specialists, even with serious problems, is unstable, situationally conditioned, sometimes is ambivalent. For example, in cases of sexual abuse of a child, as a rule, the victim is distraught, suffering and seeking help, but at the same time fears

\footnotetext{
22 Мітіна С.В. Протидія насильству в сім’ї щодо неповнолітних. Науковий вісник Херсонського державного ун-ту. Серія «Психологічні науки». Херсон, 2015. № 2, С. 100-104.

${ }^{23}$ Domestic Violence Perpetrator Programs in Europe, Part I: A survey of Current Practice. International Journal of Offender Therapy and Comparative Criminology. 2012. № 10.

${ }^{24}$ Державна доповідь про становище дітей в Україні «Реалізація конвенції ООН права дитини в Україні: досягнення, проблеми, перспективи» (за період 2009-2016 р.р.). Київ: Міністерство соціальної політики України, 2016. С. 51.
} 
the condemnation because the child considers himself guilty of crimes, fear of the negative judgment or disbelief in the ability to change something. Therefore, it is important that the crisis management mode will be optimal and will provide the maximum availability for those who want help.

It is important to remember that the outsiders, neighbors, relatives, and friends are often approached about child victims of domestic violence. That's why it is very important the interaction between the specialists of different professions - psychologists, doctors, educators, social workers, lawyers. $t$ makes possible to solve the child's problems comprehensively and to see the situation from different points of view, including, if necessary, the organization of legal and medical assistance in other institutions, which increases the effectiveness of the results many times over.

To increase the protection and social and psychological rehabilitation of victims of domestic violence N.Yu. Maximova considers that it is advisable to create the interdisciplinary team, namely the group of specialists who work with the specific case at the stage of social intervention. The basis of the work of such interdisciplinary group is the process of considering of the case of violence. In the process of reviewing the case, each of the professional groups has two tasks:

1) to provide the services in their specialty to the family in which the violence took place;

2) to communicate and cooperate, exchange the information with representatives of other professional groups to provide services to this family ${ }^{25}$.

The various services that are part of the team operate within their respective roles and responsibilities. The cooperation with other services is, firstly, in the exchange of information, which obtainable by the course of work with the family, and secondly, in the definition and application of those roles of a particular service, that are need in this particular case.

The main advantages of the multidisciplinary approach are:

1. The increasing of the effect of communication between professionals of different specialties dealing with violence. The exchange of information provides the more comprehensive experience of situations in the specific families, enabling them to develop more effective methods of assistance for specific families and to gain experience to improve the level of assistance in general.

\footnotetext{
25 Максимова Н.Ю. Психологія соціальної роботи із проблемними сім’ями. Київ: ВПЦ «Київський університет», 2017. С. 334.
} 
2. The creating of information base to determine the best way to help the different types of families, depending on their characteristics.

3 . The increasing of the motivation of specialists in different specialties.

4. The deepening understanding of the problem and the variety of possible measures, which can be take to overcome it.

The confidentiality of appeals is the crucial condition for dealing with the crisis situations. This principle is very important in work with teenagers who are painfully concerned with the need to seek help for fear of "looking weak", unable to cope with their problems. The anonymity and confidentiality are particularly relevant dealing with victims of sexual abuse.

It should be noted that many adolescents who have experienced the domestic violence (especially those leading an asocial lifestyle, use drugs, etc.) have the negative experiences with adults and do not trust them. In this regard, it is important to create the unprofessional youth associations (self-help groups) that contribute to the organization of the sociotherapeutic environment. The main objectives of this group is the adaptation to the therapeutic process, the ease of teenagers' integration with the group of peers. Communication with the peers helps to reduce the fear, anxiety, distrust of psychologists and doctors, provides teens the information about opportunities of professional help. The example of creating of therapeutic environment for teens is the teenage volunteer helpline. The recruitment of volunteers to the training group to work on the telephone of trust of adolescent problems can be carried out by studentspsychologists, social workers, educators, doctors, which also gives them the opportunity to gain the practical skills. In times of crisis, talking to teenagers-peers on the helpline is often the intermediate for seeking professional help.

The main task of medical and psychological care is to carry out the individual, family and group psychotherapy, with the aim of minimizing the psychological consequences of violence and the working out of traumatic experiences. The abuse provokes many negative emotions: the pain, hurt, fear, anger. Herewith, the child may have the ambivalent feelings to the family member from whom he is experiencing the abuse. These experiences can interfere the spontaneous narration and verbalization of the problem. In this case, it is advisable to conduct the 
psychotherapy with the use of art-therapy, fairy-tale therapy and psychodrama, with which the child is able to respond to negative emotions.

We think that in addition to helping the child, in order to further prevent of domestic violence, the comprehensive work with the whole family is required, which provides the involvement of lawyers, social services, rehabilitation institutions and other social institutions. However, the work of the services should be organized taking into account the gravity of the violence and the degree of social disadvantage of the family, because its content is fundamentally different, for example, dealing with asocial families and parents who are dependent on alcohol, than working with externally prosperous families, but in which the violence against the child is also used. It should be emphasized that defining the forms of work with the parents, we do not mean the serious forms of violence (physical or sexual) that require the immediate isolation of the child and the criminal responsibility of the parents.

The most common type of violence in the socially disadvantaged families where parents abuse the alcohol is abusive treatment of the child, ignoring him or his needs. But despite family disadvantages, the placement in residential care is a strong traumatic factor for the children because of the loss of their parents, deprivation of their parental rights. That is why the main task of the work with alcohol addicted parents is to provide them the medical, psychological and social-legal assistance aimed to the treatment, motivation of parents to change their way of life, assistance in employment and further social support of the family.

The reasons of violence against the child in outwardly prosperous families are the conflicted relationships, the lack of emotional attachment, the mutual understanding between the family members. The social and psychological assistance is to organize the comprehensive work with the family to improve the conditions of family upbringing. In this case, it is advisable to conduct the family psychotherapy in order to normalize the relationships. In the case of physical abuse of a child, the social intervention and outreach to parents are required. If necessary, the offer to the child a temporary shelter, which will allow the parents to rethink their educational impact. In this case, it is advisable to start the family therapy course separately with the child and the parents, and finally with the participation of all family members. The refusal from the use of physical punishment is possible when the parents realize the consequences of their 
actions, the transformation of ideas about themselves at the cognitive and emotional levels, the reflection of their own childhood experience, getting help in solving their own problems ${ }^{26}$.

Based on the peculiarities of family relationships, the work with parents should be done according to the algorithm:

1. Overcoming mistrust, reaching an agreement for cooperation. So long as the parents attached to their children, the informing that the child will return to the family only after the parents change their behavior and their attitude to him will serve as an external motivation for cooperation.

2. Parenting negative emotions gives parents an opportunity to change their view of the situation, before constructively discussing the existing problems. Often, the physical punishment is caused by parents' inability to control their emotions. When we have the work with parents, it is advisable to apply the psychotherapeutic techniques that are aimed to forming the skills of self-control of aggressive impulses, techniques of self-regulation.

3. Helping parents overcome their own problems. Often, these parents themselves have suffered from childhood abuse and do not know the other methods of education. The lack of control over one's impulses is often associated with inadequately low self-esteem, self-doubt, and a negative self-concept. Aggressiveness in this case is a manifestation of powerlessness and correction of only its external manifestations is not enough, it is necessary the methods of overcoming the intrapersonal conflicts.

The general result of group psychotherapy is the change in family relationships, the acquisition of constructive ways of responding to family problems, which consequence is the restoration of emotional attachment and prevention of domestic violence. This can be done by the centers of social and psychological assistance to the family. The primary purpose of the psychologist is to assist the family members in identifying resources to overcome the crisis in the family. It may also be important for family members to develop the productive problem-solving skills and positive communication, for this purpose it is appropriated the communicative training.

Thus, the use of various forms of social and psychological assistance depends on the type of violence and the peculiarities and problems of each

\footnotetext{
${ }^{26}$ Удовенко Ю.М. Система служб соціально-психологічної підтрімки дітей- жертв насильства (вітчизняний та зарубіжний досвід). Актуальні проблеми психологї̈: зб. наук. праць Ін-ту психології ім. Г.С. Костюка АПН України. Київ, 2006. Т. VIII, вип. 2. С. 336-342.
} 
individual family. In the course of work, these forms can change and be combined: telephone counseling, eye counseling, family counseling, individual and group psychotherapy.

\section{CONCLUSIONS}

The analysis of the literature has shown that the domestic violence of the children are manifested in different forms, have some dynamics of formation and varying degrees of expression. The families where children have abused are unequal in terms of social and material well-being, as well as the degree of emotional closeness between family members. In dysfunctional families the children are less protected from psychological trauma situations. The domestic violence is a product of socialization, this is the production of the model of behavior, the life experience that the child has received in the family.

The violence against children in the family has considered within four categories: neglect, psychological violence, physical violence and sexual violence. It should be noted that the psychological violence is an integral part of all types of violence. The violence against children always causes the negative consequences and raises a variety of problems, both social and psychological. The psychological consequences of all forms of violence against the child are the emotional disorders, anxiety, fears, impulsiveness, inadequate self-esteem, lack of trust in people, hostility. Thus, the domestic violence leads to personal changes that impede the child's ability to realize himself in the future.

In our opinion, to solve problem of domestic violence, it is necessary to carry out a comprehensive social and psychological work with the whole family, which provides a differentiated approach, taking into account the specifics of the family and the type of domestic violence, and is aimed at providing assistance to the child, as well as to work with each family member. The effectiveness of social and psychological work is provided by various forms of assistance: helpline, individual counseling, family counseling and family psychotherapy. The use of different forms of work depends on the problem and the characteristics of the family. The solution of the problem of domestic violence is possible through the implementation of a comprehensively differentiated approach. 


\section{SUMMARY}

The actual socio-psychological problem of the domestic violence against the children is considered. On the basis of theoretical analysis of the psychological literature it was found that the violence in the family is a complex phenomenon and has different forms and features, but always accompanied by coercion and control, physical and psychological pressure. It was found that the most acute problem is domestic violence against children. It was considered that the violence against a child is as a result of negative personal life experiences of parents, "trauma of childhood", alcoholism, psychopathology, or as a symptom of the dysfunctional family. It is set that the violation occurs as a result of violence, which affects all levels of human functioning and raises many problems, both social and psychological. It was underlined that the violence hinders the mental and personality development of the child. It was concluded that to overcoming the violence against the children it's important such system of social and psychological assistance's structure, which provides the complex and differentiated approach aims to assure the child's assistance and to conduct the work with each member of the family for the purpose of further prevention of violence in the family.

\section{REFERENCES}

1. Алексеева И.А., Новосельский И.Г. Жестокое обращение с ребенком. Причины. Последствия. Помощь. Москва: Генезис, 2005. C. 195 .

2. Бегеза Л., Алєксєєва В. Насильство над дитиною як чинник деструктивного впливу на формування ії̈ особистості. Сучасна школа України. 2011. № 9. С. 47-92.

3. Болтівець C.I. Домашнє насильство як підгрунтя девіантної поведінки підлітка. Практична психологія та соціальна робота. 2009. № 10. С. 38-39.

4. Гончарова Т.В. Насильство дітей у сім’ї: умови, причини й фактори виникнення. Соціальна педагогіка: теорія та практика. 2010. № 4. С. 47-53.

5. Державна доповідь про становище дітей в Україні «Реалізація конвенції ООН права дитини в Україні: досягнення, проблеми, перспективи» (за період 2009-2016 р.р.). Київ: Міністерство соціальної політики України, 2016. С. 51. 
6. Domestic Violence Perpetrator Programs in Europe, Part I: A survey of Current Practice. International Journal of Offender Therapy and Comparative Criminology. 2012. № 10. P. 56.

7.Закон України "Про запобігання та протидію домашньому насильству” від 7 грудня 2017 року № 2229-19 [Електронний ресурс]. Режим доступу: http://zakon3.rada.gov.ua/laws/show/2229-19

8. Кондратенко Л.О. Рання діагностика жорстокого ставлення до дитини з боку рідних. Практична психологія та соціальна робота. 2009. № 10. С. 40-41.

9. Кацеро А.О. Структура та зміст «Я»-образу у бездоглядних підлітків. Актуальні проблеми психології: зб. наук. праџь Ін-ту психології ім. Г.С. Костюка АПН України. Київ, 2005. Вип. 3. С. 148-156.

10. Максимова Н.Ю., Мілютіна К.Л. Соціально-психологічні аспекти проблеми насильства. Київ: Комітет сприяння захисту прав дітей, 2003. 344 с.

11. Максимова Н.Ю. Основи психології девіантної поведінки. Київ: ПЦ «Київський університет», 2008. 439 с.

12. Максимова Н.Ю. Психологія соціальної роботи із проблемними сім'ями. Київ: ВПЦ «Київський університет», 2017. 467 с.

13. Мельник Л.П. Насильство над дітьми як соціальнопедагогічна проблема Корекиійна та соиіальна педагогіка $i$ психологія. 2013. Ч. 2. С. 135-143.

14. Мінц М.О., Фесенко А.М. Насильство в сім'ї як фактор соціальних девіацій. Міжнародне періодичне наукове видання. 2013. № 2 (39). С. 17-26.

15. Мітіна С.В. Психологічні чинники становлення особистості

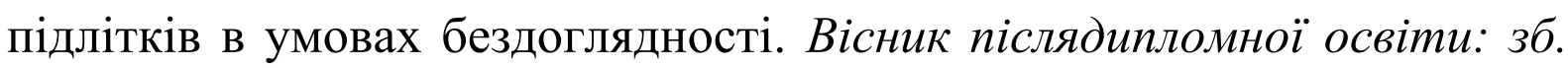
наук. пращь. Київ, 2012. Вип. 8 (21). С. 256-262.

16. Мітіна С.В. Соціальні чинники становлення особистості бездоглядних підлітків. Вісник Київького Наџіонального університету імені Тараса Шевченка. Київ, 2013. № 1 (7). С. 74-77.

17. Мітіна С.В. Протидія насильству в сім’ї щодо неповнолітних. Науковий вісник Херсонського державного ун-ту. Серія «Психологічні науки». Херсон, 2015. № 2, С. 100-104.

18. Стрельченко О.Г., Сущенко А.О. Адміністративно-правова протидія насильству в сім'ї як соціальна проблема в Україні. Ученье 
записки Таврического национального университета им. В.И. Вернадского. Серия «Юридические науки». Том 27 (66). 2014. № 1. С. 138-144.

19. Сукмановська Л.М. Домашнє насильство: дослідження актуальної проблеми сьогодення. Юридичний Вестник. № 4. 2014. C. 215-219.

20. Удовенко Ю.М. Система служб соціально-психологічної підтрімки дітей- жертв насильства (вітчизняний та зарубіжний досвід). Актуальні проблеми психології: зб. наук. праџь Ін-ту психології ім. Г.С. Костюка АПН України. Київ, 2006. Т. VIII, вип. 2. C. 336-342.

21. Чаплінська Л. В. Проблема психологічного насильства над дітьми дошкільного віку: причини, види та наслідки. Науковий вісник Мукачівського державного університету, 2015. Випуск 1 (1). C. $125-129$.

22. Ярославцева Н.В. Система мер по оптимальному жизнеустройству детей Работник социальной службы. 2003. № 2. С. 25-28.

\section{Information about the author: Mitina S. V.}

$\mathrm{PhD}$ of Psychology, Associate Professor, Associate Professor at the Department of Psychology and Pedagogy of the V. I. Vernadsky Taurida National University 33, Ivana Kydri str., Kyiv, 01042, Ukraine Researcher ID: G-7268-2017 ORCID: 0000-0001-9520-0272 


\title{
THE ISSUE OF THE RESEARCH OF CRIMEAN TATARS' ETHNO-PSYCHOGENESIS AND ETHNIC AWARENESS
}

\author{
Osmanova A. M.
}

\section{INTRODUCTION}

The issue of the research of ethno-psychogenesis and ethnic awareness has a wide theoretic and empirical basis. At the same time, it is based on various understanding of ethnic essence, nature and structure. The study of ethnic awareness is taking place within various sciences, namely: philosophy, ethnology, psychology, and sociology etc. Based on the experience of awareness research one can state that a person, preserving stable mental structures inside, is still in constant self-search and self-development.

Marking the people clearly, ethnic self-awareness gives not much to the defining of common origin of people's group, namely in the reconstruction of "ethno-genetic bundles". . One should seek the basis of ethnic awareness not only in the people's ethno-genetic roots, but also in the information of cultural nature. Summarizing the set of basic paradigms of ethnic culture is no less meticulous and multifaceted task than the study of ethnic roots. Any phenomenon of spiritual and material culture, even the smallest one, may appear informative here. To catch the worldview integrity of ethnos, it is important to understand that every artifact of culture, whether it is a ritual, a phenomenon, an act, is bound by many indirect threads with one another, thus creating a certain balanced completeness, harmony of personality and the group, family and the surrounding world.

The study of the ethno-psychogenesis of any nation is a complex problem and is further complicated by the fact that it contains all the essential features of becoming an ethnic community in its historical retrospective. This, in turn, raises a number of difficulties, including in the interdisciplinary area. A comprehensive research of psychogenesis provides for the involvement of materials from the often unexpected fields of knowledge in the scientific circulation, including natural sciences, a

\footnotetext{
${ }^{1}$ Алексеев В.П. Етногенез : учеб. пособ. / В.П. Алексеев. - М. : Высш. шк., 1986. - 173 с.
} 
constant attraction to an interdisciplinary approach and a thorough possession of ethnology, archeology, mythology, etymology, etc. This circumstance leads to the necessity to develop optimal methodological foundations, in which the content and structure of the leading factors of genesis are almost decisive.

The process of ethno-genesis is basically the creation of a living "bundle of collective reality" 2 that can be formed only when it gathers a large and varied amount of potencies from the very beginning. Without such matter, the new "collective reality" will not be able to individualize by ethnic color. Ethnicity is based on the people's psycho-physiological features, caused by they gene pool, that is, ethnicity appears as a "specific set, a system of traditional forms of responses to surroundings, a set of common norms of behavior and activity. At the same time, the traditional form of reactions to the world or common norms of activity can have both social and natural origin",

Ethnologists quite fairly associate the origin of the particular people, primarily with a particular territory, with a particular geographical environment. The people adapt to the landscape by subordinating their activities to survival under these natural conditions (agriculture, cattle breeding, fishing, hunting, etc.) and create the culture associated with it. Crimea is no exception in this respect.

In recent years, a considerable amount of actual information on the ethnic history of Crimea has been accumulated. Numerous publications have covered various aspects of the history of the peoples having inhabited the peninsula. That is why there has been an urgent necessity to summarize the results of the studies conducted. This task has been solved in the article by A. Aibabin, O. Herzen, and I. Khrapunov, "The main problems of the ethnic history of the Crimea" rather successfully. It emphasizes that "the Crimean Tatar ethnos was formed mainly on the peninsula influenced by political, ethno-cultural, and denomination factors. In the steppe part of the peninsula, Turkic-speaking nomadic ethnic groups have repeatedly changed. Yet, in the first decades of the X century Pechenegs appeared here destroying the Bulgarian population in Eastern Crimea; and in the middle of the XI century Polovtsians settled. By the XIII century a mixed Pechenegs-Polovtsians ethnos was formed. In January 1223 the Tatars

\footnotetext{
${ }^{2}$ Алексеев В.П. Етногенез : учеб. пособ. / В.П. Алексеев. - М.: Высш. шк., 1986. - 173 с.

3 Бороноев А.О. Национальный характер и особенности развития России: механизм сопряжения / А.О. Бороноев., П.И. Смирнов // Регионология. - № 2. - 2001. - С. 208.
} 
invaded the Crimea. In the sources such ethnonym as "the Mongols" is not practically used for their description, but only "the Tatars". The excavation materials give a reason to talk about the fact that in the northwestern Black Sea region and the steppe Crimea there was no complete change of the population in the XIII century, and it was the same earlier in XI century"4.

Evaluating the current state of research on the Crimea ethnic history and its development prospects, the authors of the article note that "at present, the Crimean Tatars are an ethnos, with a consolidated awareness of their origin unity. In their surroundings, the idea of the ethno-genesis autochthonous nature is especially persistently spread, its initial stage being a priori identified with the Cimmerians, or Tauri",5. In conclusion, the authors make a categorical statement of the following content: "None of the present peoples living on the peninsula can be related to Cimmerians, Tauri, and Scythians by ethno-genesis. This connection with the early medieval ethnic communities is quite problematic as well",6.

Filling the existing vacuum in the theory of the Crimean Tatars' ethno-genesis, V. Vozgrin notes in the book "The Historical Fate of the Crimean Tatars" that the origins of the ethno-genesis of the present Crimean Tatar people go back to prehistoric times. According to V. Vozgrin, the gene pool basis of the Crimea includes Tauri, Cimmerians and Scythians. At the same time, a special place is given to the Tauri. "Most of our national and foreign scientists consider the Tauri to be Aboriginal of Crimea, moreover, with Indo-Aryan origin"7. V. Vozgrin believes that during the forced migration, the inhabitants of the steppes mostly descendants of the Huns, Bulgarians, Khazars, Pechenegs, Polovtsians left Crimea, but the mountain and south-coast population remained in their habitats. "The relationship between the autochthonous European and the strange, mainly Mongoloid, Asian population $<\ldots .>$ has changed dramatically in favor of the former"

There is another version of the Crimean Tatars' origin (R. Fazil, S. Nagaev, R. Muzafar). Thus, R. Fazil and S. Nagaev's article "Heart of the People" contains the concept of ethno-genesis of the Crimean Tatars,

\footnotetext{
4 Айбабин А.И. Основные проблемы этнической истории Крыма / А.И. Айбабин, А.Г. Герцен, И.Н. Храпунов // Материалы по археологии, истории и этнографии Таврии. - Симферополь : Таврия, 1993. - Вып. 3. - С. 117.

${ }^{5}$ Там само, с. 117.

${ }^{6}$ Там само, с. 118.

${ }^{7}$ Возгрин В.Е. Исторические судьбы крымских татар / В.Е. Возгрин. - М. : Мысль, 1992. - 446 с.

${ }^{8}$ Там само, с. $298-299$.
} 
different from that proposed by V. Vozgrin. "A large number of these tribes (Kipchaks) settled in the Crimea at that time, where they mixed with the local descendants of the Huns, Khazars, and Pechenegs, lived there, and then formed the ethnic basis of modern Crimean Tatars with them. Among such first Muslims of the Crimea in the XII - XIII centuries the first memorial of the Crimean Tatar language - the Kumanicus Code - was created. It is unanimous that the language of the Crimean Kipchaks was more developed and perfect than the dialects of the later hordes that came to the Crimea, in which various Turkic and Mongolian elements were mixed, and that is why the Kipchak language served as the basis for the formation of written, literary Crimean Tatar language""9.

R. Kurtiev introduces his concept of the ethno-genesis of the Crimean Tatars in the book named "Crimean Tatars: Ethnic History and Traditional Culture", whose central idea is the synthesis of two ethnic components that are very different from each other - the autochthonous non-Turkic agricultural population of the peninsula and the nomadic Turkic tribes, entering its territory not only once. The book traces the cultural assimilation of autochthonous peoples on the basis of Turkization and Islamization, proposes a new version of the periodization of the ethnic history of the Crimean Tatars, and studies theoretical problems of the relationship between the ethnonym of "the Tatars" and the ethnos of "the Crimean Tatars" $"$.

In the $\mathrm{X}$ century on the peninsula there is a Europeoid anthropological type of population with Turkic component of culture. With the arrival of the Turkic tribes - the Pechenegs (first half of the X century) and the Polovtsians (the middle of the XI century) - the second period in the history of the Crimean Tatars' ethnic core formation (kyrymlylar) begins, which can be called "Kipchak". Prior to the invasion of the Mongols (first quarter of the XIII century), an ethno-linguistic Pecheneg-Kipchak community formed on the peninsula, part of which settled in the foothills and southeastern Crimea, gradually mixing and dissolving in the local population, intensifying its Turkization. Later on, the Kipchaks of the peninsula steppes form the basis of the Crimean Ulus population of the Golden Horde (mid-XIII - the first half of the XV century), of the Crimean Khanate (the first half of the XV - the end of the XVIII century). After the

\footnotetext{
${ }^{9}$ Фазыл Р. Сердце народа / Р. Фазыл, С. Нагаев // Звезда Востока. - 1989. - № 3. - С. 135-143.

10 Куртиев Р. Крымские татары: этническая история и традиционная культура / Р. Куртиев. Симферополь: Б. и., 1998. - 151 с.
} 
conquest of the Crimea by Russia, the steppe Kipchaks of the Crimea are formed into an ethnic group of Crimeans. However, according to the author, the core of kyrymlylar continues to be the Turkic-speaking Muslim population of Taurica (the peninsula mountain and forest area). "During the period of joining the Russian Federation, deportation and residence in places of deportation in the republics of Central Asia (1944-1998), the process of forming a dialect-free people of the Crimeans was taking place" $" 11$.

A. Memetov in his work "Crimean Tatars: a Historical and Linguistic Essay" outlined the main ethno-genetic processes of the Crimean Tatars. Taking into account the commonality of language and culture, contemporary Crimean Tatars differ in their physical type depending on which groups participated in their ethno-genesis. The scientist has distinguished three main groups of Crimean Tatars: inhabitants of the Southern coast of Crimea, Tatars of mountain and foothills Crimea and steppe inhabitants of Crimea ${ }^{12}$.

Thus, the ethnic basis of the south-coast and mountain Tatars was the descendants of the Cimmerians, the Greeks, the Tauri, the Scythians, the Alans, the Goths, the Huns, the Genoese, and also partly the Khazars, the Polovtsians, the Seljuks Turks.

The ethnic basis of the steppe inhabitants of the Crimea was mainly Kipchak-Polovtsian tribes. The remains of the Khazars, Pechenegs, Guzy (Torc), partly Mongol-Tatars and Nogai participated in the ethno-genesis, mixing with the Kipchaks ${ }^{13}$.

The complex historical and ethno-genetic processes appearing after the formation of the Crimean Tatar people were reflected in their language. Tribal languages participated in the formation of the national Crimean Tatar language, mainly Kipchak and to a lesser extent Oguz, that is proved by the characteristic features of its basic dialects. Defining the place of the Crimean Tatar language among other Turkic languages, K.M. Musayev includes it in the West Kipchak group together with Kumyk, KarachayBalkar and Karaite ${ }^{14}$.

\footnotetext{
11 Куртиев Р. Крымские татары: этническая история и традиционная культура / Р. Куртиев. Симферополь: Б. и., 1998. - 151 с.

12 Меметов А. Крымские татары: историко-лингвистический очерк / А. Меметов ; [ред. С.К. Сосновский]. - Симферополь : Анаюрт, 1993. - 55 с.

13 Там само, с. 34.

${ }^{14}$ Мусаев К.М. Лексика тюркских языков в сравнительном освещении. Западнокыпчакская группа / К. М. Мусаев. - М. : Наука, 1984. - 226 с.
} 
E. Kudusov in his work "The History of the Formation of the Crimean Tatar Nation" associates the origin of the Crimean Tatars with a certain territory, a certain geographical environment and, based on this precondition, makes a conclusion that the native population of Crimea, so to say, an ethnic expression of its original nature is the Crimean Tatars, the Crimean Karaites and the Krymchaks are autochthons originating from peoples who lived there for 2.5 thousand years ${ }^{15}$.

In the formation of the Crimean ethnos (kyrymlylar) the author gives a special place to the Cimmerians, the Tauri, the Greeks, the Scythians, the Romans, the Sarmatians, and the Goths. However, according to E. Kudusov, the Turkic tribes of the Huns, Khazars, Pechenegs, Polovtsians were dissolved, found shelter in the mountains of the peninsula, who contributed to the formation of the native ethnos. At the same time, the Mongol-Tatars of the XIII century were quite easily assimilated by the aborigines of the Crimea. E. Kudusov makes an emphasis on the southern coastal area and mountains of the Crimea, which were a shelter for the steppe Crimea inhabitants from various conquerors and eventually became a cradle for the ethnos formation.

In his conclusion E. Kudusov justifies the idea of the Crimean Tatar nation emergence and development as a people's voluntary community united under the slogan of a single idea and future common goals, ready to uphold the order established by this state. The researcher identifies several stages in the period between XV-XVIII centuries and later on: the incubation period is based on the idea of separation from the Golden Horde and the achievement of independence; 1443 - legal registration of independence and creation of the Crimean Khanate; the stage of maturity, expressed in success in the economy, in foreign affairs, the termination of the national state existence, the transformation of Crimea into a province of the Russian Empire; Crimean Tatars' emigration; deportation and repatriation $^{16}$.

Yu. Zinchenko gives his version of the Crimean Tatars' ethno-genesis, according to which this process took place in two stages. The peninsula population was a complex ethnic group, uniting the descendants of the Cimmerians, the Tauri, the Scythians, the Greeks, the Sarmatians, the Alans, and the Goths before the invasion of the Huns. An intense process

\footnotetext{
${ }^{15}$ Кудусов Э. История формирования крымско-татарской нации / Э. Кудусов. - Б.м.: Б.и., 1996. - 32 с.

${ }^{16}$ Кудусов Э. История формирования крымско-татарской нации / Э. Кудусов. - Б.м.: Б.и., 1996. - 32 с.
} 
of assimilation was taking place between them, proving the existence of the term "Tauri-Scythian" in everyday life, as well as the archeological monuments of that time, in which the features of ancient Greek culture intertwined with the culture of the local population. The second stage is characterized by the prevalence of the Turkic tribes of the Huns, the Polovtsians, the Seljuks Turks, and others' influence. The process of the Crimean Tatars' formation as an ethnos continues in the XIII - XVI centuries as well. As a result, two main groups of the Crimean Tatars emerged in the Crimea: the steppe (northern Crimean) and southern coastal ones, which differ from each other in anthropological features and language ${ }^{17}$.

The given material gives an opportunity to consider in more detail and describe the tribes who participated in the ethno-genesis of the Crimean Tatar ethnos, as well as to reveal their direct reflection of reality, understand people's world perception and worldview.

Therefore, the first people in the territory of Crimea, having their own name, were the Cimmerians (IX - VII centuries BC). There are recollections about Cimmerian tribes in Homer's "Odyssey", Herodotus' "History", and some Minor Asian sources. Their religious worldview is characterized by faith in the soul and life after death. This is proved by excavations of burial mounds, where the things are found used by the dead during the life. In men's burials there are daggers, details of horse weapons, sometimes the remnants of the horse, arrowheads, sacrificial food. In women's burials there are gold and bronze temporal rings, glass, gold necklaces, and pottery.

In the Cimmerians, the emergence of the Mother Goddess' cult is indicated by steles depicting the woman having a cult nature. The Mother Goddess' cult is the most typical feature of the formation of many peoples' religious awareness. The feminine nature was the cradle song of all religions, which was fertilized and flourished from contact with male nature. Man and woman started the world, and the most expressive attributes of their gender were adored. Ancient religions also praised the love of the mother as the sole nurse and child protector.

One of the most ancient Crimean peoples were the Tauri who lived in the foothills and mountains of Crimea, as well as on the Southern coast.

\footnotetext{
17 Зінченко Ю. Кримські татари: Історичний нарис / Ю. Зінченко / Ін-т політ. і етнонац. досліджень НАН України. - К. : Голов. спеціаліз. ред. літ. мовами нац. меншин України, 1998. - С. 205.
} 
The ancient name of the mountain and coastal part of Crimea - Taurika, Tauriya, Taurida is originated from the Tauri. They left significant memories of themselves in the culture of the Crimean people, including material ones. It is possible to name many Scythian, Roman, Greek, Pontic and then Tatar settlements, built on the foundations of Taurian settlements and fortresses ${ }^{18}$.

With the expansion of the Scythians to the Crimea begins a new period of the peninsula history, characterized by qualitative changes in its population composition.

The Scythians' religion reached the developed polytheism. The Scythians stood on the verge of creating a national-state religion with a certain nation-wide pantheon of higher gods. The Scythian religiousmythological system combined the elements of zoomorphic symbolism of animal style with anthropomorphic mythologeme, elements of cattle breeding culture totems with the Greek mythology influence.

A wide range of Scythians' religious ideas prove the variety of Scythian religion forms: the cults of ancestors, heroes, tribal chiefs, the funeral cult and the fertility cult, whose objects were water, earth, plants, animals and the sun.

The Scythian state in the Crimea existed until the second half of the III century B.C. and was destroyed by the Goths (Scandinavian group of tribes).

The desire to self-identify inevitably provides for the awareness of these ethno-factors in the Crimeans creation, since the Crimean population was a complex ethnic group, consisting of descendants of the Cimmerians, the Tauri, the Scythians, the Greeks, the Sarmatians, the Alans, and the Goths. An intense assimilation process took place between them.

Understanding the Crimeans ethno-genesis requires awareness of Sarmatians' participation in it. They began to penetrate the Northern Black Sea in the last centuries B.C. This nomadic people, mostly Iranian, leaving the Lower Volga and the Cisurals, went to the West.

The Sarmatians' beliefs were not very different from those of the Scythians. Now one can speak of the inheritance of religious traditions. The cults of sun and fire and the Great Mother Goddess Astarte, the patron saint of horses, as well as the cult of the God of war, whose embodiment

\footnotetext{
${ }^{18}$ Храпунов И.А. Очерки этнической идентичности истории Крыма в раннем железном веке: Тавры. Скифы. Сарматы / И.А. Храпунов. - Симферополь : Таврия, 1995. - С. 78.
} 
was the sword, dominated in the Sarmatians. In addition, the factors of sensory-supersensory type of the supernatural can be found in the Sarmatians: worshiping the inanimate objects and endowing them with the soul, belief in the magical power of stones, and so on.

The Sarmatians believed in the afterlife, and therefore the cult of the dead was of great importance in their beliefs.

The same as with the Scythians, the Sarmatians gave a special magic power to the mirror. The Sarmatians' custom of breaking mirrors at burial was an echo of various ancient ideas, according to which the mirror as the receptacle of the soul was opposed to death. And at present, it is common to hang mirrors in a house where the deceased is present, and there is a belief that a broken mirror foretells death. At the same time, there is a ritual in which the mirror is a traditional attribute. It means the wedding ritual and the traditional fortune telling about the bridegroom.

Another factor declares itself in a reliable way - in the second half of IV century Turkic-speaking tribes appeared in the Crimea, Turkization of the local Hun population (according to other sources - Gun) began ${ }^{19}$. In the 70's of the IV century mass movement of the Turkic Hun tribes began (the Utigurs, the Kutrigurs, the Bulgars, the Akatsirs, the Sargurs, the Sabers, the Khazars, etc.). They open the first pages of the Crimea Turkic history, coming to replace the millennial rule of the Iranian tribes (the Cimmerians, the Scythians, the Sarmatians, etc.). From the second half of IV century the nomadic Iranian-speaking tribes are being replaced by the peoples of the Altai language group - the Huns, the Avars, the Bulgars, the Khazars. In 375 , the Ostrogothic Union was defeated by the Huns, nomads of Turkic origin who came from Central Asia and conquered by that time some Hungarian and Sarmatian tribes. Between 375 and 453, the Goths were part of the Hun state. And the Hun leader Attila was sung in the German epic literature. In general, it was a period when the Slavs, the Germanic people, the Hungarians, and the Turks mixed in one historical maelstrom, which in turn led to the formation of new ethnic groups. It is the Huns who were in the center of this maelstrom, who conquering and uniting Germanic, Slavic, Sarmatian and Thracian tribes around them. At the same time, one should speak about mutual assimilation, especially when it comes to religion.

\footnotetext{
19 Кіндратенко А.М. Європейські гуни в описах давніх авторів / А.М. Кіндратенко. - Х. : Курсор, 2007. -359 c.
} 
These tribes, which later were dissolved among the Turkic-speaking descendants of the Crimean Tatars, left a mark in their memory, introducing a large number of Iranian origin elements into the language and culture. There was no cultural influence or any noticeable racial mixing of the coastal and mountain population of the Crimea with the Hun conquerors.

At the end of VII century in the Northern Black Sea region, in the steppe of Crimea and Sugdei (modern Sudak) the Khazars appeared. The Khazar religious view corresponded to the ancient Turkic religion. The supreme deity was Tengri, who represented the supreme power. Hagan was his vicegerent on earth. Hagan had a political charisma, so, he belonged to a family endowed with divine grace. Thus, like the Germanic people, the Turkic Khazar association was also one of the options of male unions governed by the charismatic king (Hagan).

Yet, in the VII century the Crimean Khazars were pagans, they "made sacrifices to fire and water, worshiped some gods of the roads, as well as the moon and all the creatures that seemed unusual to them" (Kagankatvatsy M., 1861, 90). So, divine substance is multifaceted, however fire and water were central, the supreme deity was Tengri-Khan. Khazar paganism was a complex amalgam of cults of different content and origin $^{20}$.

The Khazars played an important role as mediators in the cultural relations of the West and the East. The cultural significance of Khazaria was religious patience and tolerance to such religions as Buddhism, Christianity, Judaism, and the pagan religion of the Slavs. In the capital of Khazaria, Itili, Muslims had their mosques, Christians had churches, and Jews had chapels. There were also special courts for Muslims, Khazars, Christians and representatives of other religions. All this contributed to the rapprochement, cooperation and enrichment of different cultures.

After Attila's death (453), the Hun state was disintegrated. It is at that time when the Bulgar tribes appear in Eastern Europe. They were descendants of the Huns and Alan tribes of the Bulgars and inherited their religious traditions. They are sometimes called the Hun Bulgars. A strong state association - Greater Bulgaria, which included part of the modern Ukraine territories, was created by the Huns-Bulgars. Therefore, the

\footnotetext{
${ }^{20}$ Артамонов М.И. История хазар / [ред. совет: А. Я. Дегтярев (предс.) и др.]. - 2-е изд. - СПб : Лань, 2001. $-687 \mathrm{c}$.
} 
Bulgars could not stay away from the ethno-genetic and culture-creating processes that were taking place in the region at that time.

The history of the Bulgars is closely intertwined with the history of the Turkic tribes (the Huns, the Avars, the ancient Turks, and the Khazars). Fragments of the Bulgars' specific culture have been preserved in the historical memories and rituals of the Crimean Tartar mountain dwellers. They inherited the worship to fire. At the wedding, in particular, according to the old custom, the bridegroom should have a decorated rooster on the table ${ }^{21}$.

In the second half of the XI century Kipchaks entered on the peninsula territory, in addition to its mountainous part. One of the numerous Turkic tribes was called Polovtsians in Rus. They believed in the god of Heaven Tengri, worshiped the cult of the wolf (boru, kurt) and the snake (jilan) ${ }^{22}$. In the XI century most Polovtsians accepted Islam. Among the Polovtsians spiritual heritage, we can name such oral Arabic folklore as "Leila and Majnun", "Yusuf and Zuleika", later on - "Ashik-Garib", anecdotes about Hodja Nasredin, common for Islamic world, which enriched the Crimean folk cultural heritage.

By touching the history of the past times, we raise incredible cultural layers that are common, cognate for different peoples. Under the thickness of religious consciousness is a powerful stratification of archaic stereotypes of world's practical and intellectual assimilation. Religion was associated with the nature spiritualization, with its anthropomorphic properties and features. People felt as an integral part of the environment, a factor of the cycle of natural phenomena. The history of religion of a particular ethnos is, first of all, the history of its spirituality, the core of which is religion. The originality of Crimean Tatar religiosity is determined by the unity of culture and the natural environment. Its origins should be found in ancient times. The establishment of Crimean Tatar people's religiosity is closely connected with the assimilation of the components of other peoples' religiosity with which its historical paths intersected. And it still preserves that lively connection with other cultures.

As it was already mentioned, in the XII - XIII centuries the first dictionary of the language kyrymlylar, namely the "Kumanicus Code" was

\footnotetext{
${ }^{21}$ Очерки истории и культуры крымских татар / [под ред. Э. Чубарова]. - Симферополь : Крымское учебно-педагогическое государственное издательство, 2005. - 208 с.

22 Герасимова М.М. Антропология античного и средневекового населения Восточной Европы / М.М. Герасимова, Н.М. Рудь, Л.Т. Яблонский. - М. : Наука, 1987. - С. 218-221.
} 
created in Crimea. Therefore, the complex historical and ethno-genetic processes that contributed to the formation of Crimeans were reflected in its language. Kipchak and to some extent Oguz tribes took part mainly in the formation of this language, as evidenced by the typical features of its basic dialects. Therefore, the language of the Crimeans belongs to the Kipchak-Oguz subgroup of the Turkic group of the Altai language family ${ }^{23}$.

The Crimean Tatars went through a difficult and long journey in their development - from a multi-tribal union to a Crimean Tatar ethnos, which is proved by specific forms of material and spiritual culture reflected in people's bright, original features.

Within the culture established, the Crimean Tatars created their own system of rules and norms of behavior in society and family, based initially on the simplest moral ideas of good and evil, respect for the elders, hard work and collectivism. Gradually, bans and customs are being transformed into mechanisms of moral regulation, the nature of which is determined by the social way of life. Rich ethnic roots have made a significant impact on people's moral features.

The tribes of the Huns, the Turkic-Bulgars, the Khazars, the Pechenegs, the Polovtsians largely kept the heritage of the ancient ("Altai", "Siberian") Turkic civilization in their culture. During the period of tribal consolidation, statehood establishment and the Crimean Tatar people's formation, the achievements of the inhabitants of the mountain and coastal parts of the peninsula such as the Tauri, the Cimmerians, the Scythians, the Sarmatians, the Ancient Greeks, the Alans, the Goths and the Byzantines contributed to the culture as a significant component. It can be traced in the mythology and folk knowledge of the Crimean Tatars, as well as in the development of their material culture.

A new stage in the ethno-psychological development of the Crimean Tatars' society was associated with the spread and promotion of Islam in the Crimean territory.

The most significant stages in the formation of the Crimean Tatar people and their worldviews are related to the period of the Crimean Khanate (1443-1783). The process of ethno-psychogenesis of Crimeans

\footnotetext{
${ }^{23}$ Меметов А. Крымские татары: историко-лингвистический очерк / А. Меметов ; [ред. С.К. Сосновский]. - Симферополь : Анаюрт, 1993. - 55 с.
} 
took place on the background of the Islamic canon transformation into a national tradition, way of life and awareness of the people.

In fact, Islam has had a great influence on the formation of the Crimean Tatar people, one of the two autochthonous peoples of Ukraine, from the first years of its existence on the Crimean peninsula. It is on the lands of the Crimea in the period from XIII to XVI centuries that the formation of the Crimean Tatars as a separate ethnos with its religion Islam took place. At the same time, the Crimean peninsula remained the main channel for the Dnieper region people to find out about Islam and Muslims for a long time.

However, contacting with the Muslim world, the Khans saw Islam as a powerful spiritual tool for consolidating the young people and building a strong system of political power in the state based on Sharia (Islam legal system).

Even Khan Ugedei, the son of Genghis Khan, began to treat Muslims kindly. However, the younger brother of Batu Khan - Golden Horde Khan Berke (XIII century) became a passionate proponent of Islam. Becoming a Muslim, he began to actively spread it in the Crimean Ulus. This process has intensified significantly since Berke allowed the Seljuk Turks to come to the peninsula, giving the Sudak fortress to Turkish sultan Iz-ed-Din.

However, the final establishment of Islam in the Crimea took place under Khan Uzbek (1313-1342), who officially introduced Islam as the state religion on the peninsula. Khan lived in the Crimea for some time himself, considered to be an example of adherence to Islam requirements. The legendary Tamerlane (1336-1405) completed Islamization of the Turkic-speaking population of the Crimea. Eliminating Khan Tokhtamysh, he included the peninsula in the composition of his great empire. In his policy, Tamerlane relied on Muslim clerics and promoted Islam in every possible way.

Later on, after the end of the Golden Horde period of its history, the Crimean Ulus was separated as an independent state formation, on the basis of which an independent Crimean Tatar state appeared. Since 1427 it had been under the rule of the Khans dynasty of the Girayev (Geraev) clan.

In 1475 a new period in the history of the Khanate began. That year, the Ottoman Turks, entering the peninsula, conquered the Crimean Tatar state. The rulers of Crimea became vassals of Istanbul. The affairs of the state were performed by Turkish officials appointed by the Sultan. 
Muslims' religious life on the peninsula came under the control of the Ottoman Empire as well. All high-ranking clerics were appointed with the participation of Sultan's representative, whose name was considered sacred, and was praised daily in the Crimean mosques.

The unification of secular state and religious power took place. Khan was started to be considered as Mufti (leader) of Muslims. Clerics became an influential political force in the state. The Mufti of Crimea was part of the State Council of the Empire - Divan. Further places in the hierarchical steps were occupied by cadi (Sharia judges), mudaris (responsible for teaching in Muslim schools - maktib), imams, sheikhs (heads of Muslim fraternities), souffah (members of brotherhoods or hermits). They took care of the Crimeans' education in the spirit of Islam, taught them the observance of its regulations, and educated faithful Muslims and honest citizens. Islam became the basis of the spiritual life of the Crimean Tatar people. Almost all major settlements had acting mosques, numbering at least 1.5 thousand in total. The Muslims of Crimea were successive Sunnis, although some in the North Caucasus brought Sufism here, and dervishes lived in Yevpatoria (Gezlev). Sheikh-ul-Islam was the leading authority on Muslim law, the head of the Ulema (theologians), whose title was introduced in the Ottoman Empire in 1424.

Under the influence of Islam ideas and norms, the Crimean Tatar people's national culture, their everyday traditions, language, way of life, system of education and children's upbringing was formed; writing, bookcreating, music, stone and wood carvings, ornamental art and especially architecture flourished. The city of Old Crimea is rich in valuable monuments of Muslim architecture with mosques of Uzbekistan and Babars, Kurshun-Jami and Takhtali-Jami, with madrasas, caravanserai and fountains. Many monuments of Muslim culture are in Bakhchisarai city, the former administrative center of the khanate: a palace, a mosque, and a rich collection of medieval Muslim literature in the past. The centers of the Muslim civilization of Crimea were also Karasu Bazaar (Belogorsk), Kafa (Feodosia), Gezlev (Yevpatoria) with its unique Juma-Jami Mosque (1552).

The series of brilliant Muslim culture figures flourished. They included, first of all, Khan Khoja-Devlet-Giray, Remal-Khoja, SeidMuhammad-Riza and many others. 
Under the influence of Islam ideas and norms, people's national culture, their everyday and family traditions, language, way of life, system of education and children's upbringing was formed, as well as art, writing, architecture were revealed, adapting to the doctrine, included in the existing system of religious rituals. This is proved by the peculiarity of Turkic Muslim epitaphs of the XIV century from Eski Yurt ${ }^{24}$.

Complex ethnic processes of assimilation and mutual cultural penetration, political processes aimed at the creation of a separate state (firstly - the Crimean Ulus, and then - the Crimean Khanate), led together to the emergence of a unique ethnic formation - Crimeans (kyrymlylar), united by the community of territory, languages, and religion.

Thus, our scientific analysis showed that the rich culture of the Crimean Tatar people was formed in an active connection with the process of its ethno-genesis. Due to the geographical location of the Crimea, being at the crossroads of the most important trade routes of old times (the Balkan- Caucasian, the Black Sea-Asia Minor and the Great Silk), the traces of mutual influence of different peoples in the culture, along with purely national, traditional things can be seen.

However, despite its external influence, the Crimean Tatar spiritual culture preserved its identity, developing a tradition of humanism and patriotism. Cultural achievements, penetrating from outside, were transformed and mastered taking into account the peculiarities of the local economy, housekeeping, geographical environment and traditions of the Crimean Tatars. The peculiar and original spiritual culture of the Crimeans, which at first differed with the complexity of its origins, resulted in one of the remarkable phenomena of world culture in the further development. In the Crimeans' culture a complex of certain value-oriented phenomena has been processed, making up the core of cultural and psychological attitudes, which make it possible not to lose their identity and originality.

Ethno-psychological features of the people are in close interaction with its culture and history. The pattern of formation and development of national character traits occurred at different stages of evolution just as its national awareness. "Each nation has its own special spiritual inner world, reflecting its social, geographical, ethnic, linguistic and other features", V.D. Popov argued, - and people's soul is their public psychology, so it 31 .

${ }^{24}$ Иванов А.А. Надписи из Эски Юрта в XII-XVI вв. / А. А. Иванов. - Ростов-на-Дону, 1989. - С. $24-$ 
includes such common grounds of spiritual life of each person that shape person's national character, traditions, customs, and habits. The better is the psychological health of the people, the stronger their spirit" 25 .

The national character of any nation is genetically predetermined by a long evolutionary process. The features of mental composition, types of thinking are determined not only by historically formed traditions, social environment and education, but also by hereditary potential. "In every nation, according to F.H. Cassidy, all types of temperaments, varieties of mind, and perception of the surrounding reality are represented <...> Moreover, the national character is not simply reduced to the psychic peculiarities of the people, which are most common in them. National character is a unique combination of distinctive features of a certain nation $\langle\ldots>$ Every nation is a kind of individuality, living integrity, the main features of which are the peculiarities of mental composition and types of thinking ${ }^{26}$. This is also emphasized by M.O. Lossky: "the natural originality of the national character provides for the preservation of a peculiar national face. In preservation and development of national identity, in addition to the natural strength of the people, further promotion of national upbringing and education is required" 27 . In his opinion, the main means of upbringing should be intellectual and emotional-volitional application to a specific life, to the content of national character, and national creativity.

Thus, the analysis of individual aspects of ethnic life, different driving forces of ethnic development makes it possible not only to describe the history of the people, to generalize and consider the regularities of the ethnic process, but also to identify those specific features that are the basis of ethnic awareness.

Self-identification in the first sources of ethno-psychogenesis of the Crimean Tatars remains a complex multidisciplinary scientific problem. First of all, the difficulty is in dating the point of reference of the people formation, because it is not about a one-time event but a long evolutionary process. In essence, the achievement of reasonableness, naturally complete image of kyrymlylar occurred as a result of numerous migration, assimilation, cultural-mixing processes, which, ultimately, leads to the

\footnotetext{
25 Попов В.Д. Психология и экономика / В.Д. Попов. - М.: [б. и.], 1989. - 304 с.

${ }^{26}$ Кессиди Ф.Х. Народ и нация / Ф.Х. Кессиди // Философия социологической мысли. - К., 1992. № 6. - С. 36-37.

27 Лосский Н.О. Характер русского народа / Н. О. Лосский. - М. : Даръ, 2005. - 336 с.
} 
formation of an integrated, anthropological, psychological, ethnic organism. Its ethno-psychological characteristic represents all ethnogenetic factors of previous evolutionary tendencies. Through the prism of such reflections, we have to consider the historiographical provisions explaining the origin of kyrymlylar.

Natural-geographical conditions and historical features of people's development, which determine the nature of work, games, holidays, traditions and ceremonies, the content of oral folk art, fine arts and folk crafts, the specifics of relations between people and attitudes to the environment constitute a variable characteristic of the ethno-psychology of the Crimeans. All that, in the end, contributed to the formation of such psychological features of the Crimean Tatar people as love for their native land, spirituality, collectivism, peacefulness, hard work, freedom, courage, tolerance etc.

A general approach to understanding the social norms and normative behavior gives an opportunity to identify the nature and types of normative behavior as well as the psychological mechanism of behavior in Crimean Tatar ethnic society. The material analyzed makes it possible to expand and deepen the understanding of the sources of behavioral, spiritual and moral structures of the Crimean Tatar ethnic group in our study. For many centuries, the Crimean Tatars formed their own system of rules and norms of behavior, enshrined in specific forms of folk art (crafts, traditions, customs, holidays, rituals, folklore, games, etc.), which together formed the basis of folk psychology.

Ethno-psychology of the Crimean Tatar people is based on the laws of the socio-psychological system: the presence of the ideal of personality, fixed in the sources of people's spiritual culture; interaction of social requirements; upbringing factors: nature of Crimea, history of Crimean Tatar people, including Crimean Khanate; Muslim religion, social way of life; multinational and multi-denominational nature of Crimea.

Ethnicity, reflected in the spiritual culture samples of the Crimean Tatars, is in the narrowest sense a universal vector of an ethnic idea, demonstrating the inseparability of ties with its historical past. Awareness of inseparability of these ties with the past, its succession is one of the significant markers of ethnic self-determination of the kyrymlylar (Crimeans). The Crimean Tatars' self-awareness is primarily related to the need for ethnic integrity. 


\section{CONCLUSIONS}

Ethnic awareness and self-awareness are most adequately explained within the scientific paradigm according to which traditional ethnic culture of ethnos is the way and result of group adaptation to new conditions. That is why an adequate analysis of evolutionary development stages of the Crimeans' ethnic awareness is possible in case of turning to the psychology, history, culture and religion of the Crimean Tatars.

It is detected that the roots of the Crimean Tatars's ethnic awareness are very deep and refer to the period of origin and formation of this ethnos. Since the ethno-genesis of the Crimean Tatar ethnos is based on a mixture of the autochthonous population of Crimea and the Turkic tribes, it is this objective factor that has determined the identity of the Crimean Tatar ethnic awareness.

A new stage in the ethno-psychological development of the Crimean Tatar society was associated with the spread and promotion of Islam in the Crimea. Islam defined the vector of spiritual fullness of the Crimean Tatars' ethnic awareness.

\section{SUMMARY}

The article "The issue of the research of Crimean Tatar's ethnopsychogenesis and ethnic awareness" deals with the main tendencies and areas in the study of ethno-genesis, ethnic awareness and ethnic culture of the Crimean Tatars.

It is noted that the Crimean Tatars in their development went through a difficult and long journey from a different tribal union to the Crimean Tatar ethnos, confirmed by the specific forms of material and spiritual culture reflected in the people's bright, original features.

Within the culture established, the Crimeans created their own system of rules and norms of behavior in society and family, based initially on the simplest moral ideas about good and evil, respect for the elders, hard work, and collectivism. Gradually, bans and customs are transformed into mechanisms of moral regulation, the nature of which is determined by the social way of life. Rich ethnic roots had a great influence on the moral features of the people. In people's culture, a complex of certain valueoriented phenomena was processed, making up the core of cultural and psychological attitudes, making it possible not to lose their identity and originality. 


\section{REFERENCES}

1. Айбабин А.И. Основные проблемы этнической истории Крыма / А.И. Айбабин, А.Г. Герцен, И.Н. Храпунов // Материалы по археологии, истории и этнографии Таврии. - Симферополь : Таврия, 1993. - Вып. 3. - С. 117.

2. Алексеев В.П. Етногенез : учеб. пособ. / В.П. Алексеев. - М. : Высш. шк., 1986. - 173 с.

3. Артамонов М.И. История хазар / [ред. совет: А.Я. Дегтярев (предс.) и др.]. - 2-е изд. - СПб : Лань, 2001. - 687 с.

4. Баскаков Н.А. Очерки истории функционального развития тюркских языков и их классификация / Н.А. Баскаков ; [отв. ред. Б. Чарыяров] / АН ТССР, Ин-т яз. и лит. им. Махтумкули Ашхабад: Ылым, 1988 - 138.

5. Бороноев А.О. Национальный характер и особенности развития России: механизм сопряжения / А.О Бороноев., П.И. Смирнов // Регионология. - № 2. - 2001. - С. 208.

6. Возгрин В.Е. Исторические судьбы крымских татар / В.Е. Возгрин. - М. : Мысль, 1992. - 446 с.

7. Герасимова М.М. Антропология античного и средневекового населения Восточной Европы / М.М. Герасимова, Н.М. Рудь, Л.Т. Яблонский. - М. : Наука, 1987. - С. 218-221.

8. Зінченко Ю. Кримські татари: Історичний нарис / Ю. Зінченко / Ін-т політ. і етнонац. досліджень НАН України. - К. : Голов. спеціаліз. ред. літ. мовами нац. меншин України, 1998. - С. 205.

9. Иванов А.А. Надписи из Эски Юрта в XII-XVI вв. / А.А. Иванов. - Ростов-на-Дону, 1989. - С. 24-31.

10. Кессиди Ф.Х. Народ и нация / Ф.Х. Кессиди // Философия социологической мысли. - К., 1992. - № 6. - С. 36-37.

11. Кіндратенко А.М. Свропейські гуни в описах давніх авторів / А.М. Кіндратенко. - Х. : Курсор, 2007. - 359 с.

12. Кудусов Э. История формирования крымско-татарской нации / Э. Кудусов. - Б.м.: Б.и., 1996. - 32 с.

13. Куртиев Р. Крымские татары: этническая история и традиционная культура / Р. Куртиев. - Симферополь: Б. и., 1998. - 151 с.

14. Лосский Н.О. Характер русского народа / Н.О. Лосский. - М. : Дарь, 2005. - 336 с. 
15. Меметов А. Крымские татары: историко-лингвистический очерк / А. Меметов ; [ред. С.К. Сосновский]. - Симферополь : Анаюрт, 1993. - 55 с.

16. Мусаев К.М. Лексика тюркских языков в сравнительном освещении. Западнокыпчакская группа / К.М. Мусаев. - М. : Наука, 1984. $-226 \mathrm{c}$.

17. Нордан М.В. Илам в Евразии: современные этические и эстетические концепции суннитского Ислама, их трансформация в массовом сознании и выражении искусстве мусульманских народов России / М.В. Нордан, Р.Г. Кузеев, С.М. Червонная. - М. : ПрогрессТрадиция, 2001. $-516 \mathrm{c.}$

18. Очерки истории и культуры крымских татар / [под ред. Э. Чубарова]. - Симферополь : Крымское учебно-педагогическое государственное издательство, 2005. - 208 с.

19. Попов В.Д. Психология и экономика / В.Д. Попов. - М.: [б. и.], 1989. - 304 с.

20. Фазыл Р. Сердце народа / Р. Фазыл, С. Нагаев // Звезда Востока. - 1989. - № 3. - С. 135-143.

21. Храпунов И.А. Очерки этнической идентичности истории Крыма в раннем железном веке: Тавры. Скифы. Сарматы / И.А. Храпунов. - Симферополь : Таврия, 1995. - С. 78.

\section{Information about the authors: Osmanova A. M.}

Candidate of Psychological Sciences, Associate Professor at the Department of Psychology and Pedagogy of the Educational and Scientific Humanitarian Institute of the. I. Vernadsky Taurida National University 33, Ivana Kydri str., Kyiv, 01042, Ukraine 


\section{PERSONALITY VALUES' BECOMING IN EDUCATIONAL PROCESS: TECHNOLOGY AND EXPERIENCE}

\section{Romanyuk L. V.}

\section{INTRODUCTION}

Technology of educational activity of students - future psychologists and managers - is a set of methodological, organizational and methodological guidelines and values that determine selection, composition and sequence of the tools used. It defines the strategy, tactics and techniques of education in the learning process.

A significant factor in the successful application of technology is the need to clarify values of the learning subjects and their re-orientation. The latter are based on the development of personal orientations. Various ways to develop the consciousness of future specialists are suggested by means of the content of psychological and educational impact that sets benchmarks for sense searching activities in logical and intuitive regimes. This content is considered to be the source of pedagogical creativity that is not based on readymade recipes of conduct, but rather on motives for sense creation at large.

In this regard, the main categories of psychological preparation process are the value content, which defines the meaning of education. The outlines of the notion "content" are determined by a "transparent" boundary, which allows personal meanings to its 'territory'. The purpose of psychological and pedagogical training in modern conditions is not just accumulation of knowledge and skills, but a creative approach to their acquisition, i.e., development in the course of studying psychological and educational disciplines. Since its modern meaning is multi-component, it should include not only knowledge but also ways of practical activities, creative experience, and personal values. This particular approach is able to provide quality education to meet modern requirements faced by each person in the rapidly changing society.

According to the leading educators and psychologists, one of the teacher's important tasks is to influence spiritual and mental development 
of students and their values, project the socio-cultural environment, build a psychological and pedagogical environment for normal human development at key stages of ontogenesis ${ }^{1}$ (V.A. Bolotov, V.I. Slobodchikov, 1997), i.e. creative problem solving skills are realized and self-realization is developed. These special intellectual skills enable to perceive common things in new ways, to "re-discover" a complex world of psychological and educational relations. Their individual comprehension is extremely difficult and relying on somebody else's suggestions means blocking of independence. However, there is a methodology that does not assert, does not give instructions, but encourages a thoughtful, critical insight to discover hidden causes of phenomena, or in other words, to start self-organization of the important component of psychological and managerial work, to the sense seeking activity. One of the efficient ways of humane cognitive consciousness is suggested by phenomenological psychology and pedagogy ensuring reaching deep inside into what is really human in a human being.

Phenomenological pedagogy is clearly elucidated by E. Husserl through his method of eidetic reduction. This method determines the path to the natural orientation of a person's relation with all people, with the humanity through "clearing" of consciousness filled with prejudices of "social" ideologies that divert people from their creative mission tempting them with "dissolution in public consciousness"2 (Husserl E., 1911). The overall method of eidetic reduction consists in return to one's natural human nature - and namely, to the microcosm that is represented by specific experience. Through communication with the macrocosm of human community the latter gives rise to personal human values, concepts and experiences transforming the world into a personal world phenomenon. This transformation occurs in experiences of the consciousness that create meaning and define its existence in interconnected natural phenomena. The technological design potential of high structures of a personality appears to be in the introduction of the problematic thinking. Aporetic (a problem-thinking level) creates a precondition for transition to theoretical thinking, which allows to understand the meaning and content of human values and ways of implementing them in life, thus developing consciousness. The term

\footnotetext{
${ }^{1}$ Bolotov V.A, Slobodchykov V.I. Development of Professional Pedagogical Education / Pedagogy. 1997. - № 4. - P. 66-68.

${ }^{2}$ Husserl E. Philosophy, as Strict Science. - M.: Logos, 1911, vol. 1.
} 
"personality value" indicates inclusion of consciousness not by force, but in a choice-related situation ${ }^{3}$ (Hartmann N. Ethics. - M., 1958, 11, 862).

Pillars of such cognition and self-creation are values that correspond to the subjective moral experience of an individual.

There are various psychological interpretations of values, depending on conceptual affiliations of authors. In particular, S. Freud's psychoanalysis, showing a person as enslaved by unconscious inclinations and desires, emphasizes that the Super-Ego is the highest value in the form of prohibitions and restrictions as to the manifestations of these inclinations and desires and can become hostile to an individual and stifle his productive values. And only when a compromise is reached between Id and a carrier of higher values channeling the energy of libido and instincts toward useful and productive actions, individual's values become distinctive and constructive. The Austrian psychoanalyst A. Adler rejected his predecessor's concept and argued that availability of individual values can not be achieved through a compromise between a person's unconscious and a carrier of higher values through redirection of the energy of this complex into the mainstream of productive activities. It is achieved through the innate ability that is revealed in an individual human life. Adler called this ability a social sentiment or a social interest.

A Ukrainian scientist V. Romenets ${ }^{4}$ deducts values from the structure of life. The most significant ones include values related to moral and meaning. Human values, he believes, are the first and foremost values of mutual understanding, mutual cognition and interaction (Romenets V.A., Manoha I.P., 1998).

A Russian researcher B. Parygin ${ }^{5}$ singles out value orientations as values of the society, that are to some extent acquired by individuals, as well as symbols as means of consolidation of the sanctioned system of values. They "... combine rational sense... of social values with a high emotional level and poignancy of their perception and experiences" (Parygin B.D, 1971). They are a part of the structure of the social-specific experience. He combines the above parameters into the notion of "value".

\footnotetext{
${ }^{3}$ Hartmann N. Ethics. - M., 1958.

4 Romenets V.A. Manokha I.P. History of Psychology of the Twentieth Century / Introduction by V.A. Tatenko, T.N. Titarenko. - K.: Lybid, 1998. - 992 pp.

${ }^{5}$ Parygin B.D. Fundamentals of Socio-Psychological Theory. - M: Thought, 1971.
} 
V. Yadov ${ }^{6}$ examines four levels of disposition of social attitudes in the hierarchical structure (Yadov V.A, 1975). The fourth (top) level system of values is occupied by a person's system of values, which he believes to be a dispositional hierarchy as value orientations for the purpose of life activities and means of their implementation.

In his writings D. Usnadze ${ }^{7}$ examines the phenomenon of objectification which can be attributed to psychological mechanisms of settings and values. He calls objectification a specific act which transforms the subject or phenomenon into the special objects of observation on the basis of human activity. It transforms the existing objects into subjects on which a person concentrates and objectifies them. According to him (Usnadze D.N., 1969), objectification is the result of transition of the external into the internal, from subject to object, creation of an object, with which a person interacts. The act of attention plays a significant role. It separates the object from the circle of primary perceptions based on orientations. The psychic level of objectification is inherent to people. They are capable of thinking and building foundations of cultural life and acting as creators of cultural values.

Thus, the basic idea of the system of orientations and values is that these phenomena are the result of activity of individual feelings, knowledge and behavioral reactions associated with this object. They represent value inclinations to a certain object, and their system consists of five components: orientation, cognitions (beliefs and knowledge), affective responses (feelings), behavioral intentions (intents), and behavior per se. Immediate changes in behavior patterns and verbal techniques trigger a chain reaction mechanism that changes orientations and values.

Becoming of values is their occurrence, formation in the process of person's development. They are often accepted from the environment or constitute an opposite value that proceeds from environment to a person, when the person refuses to identify himself with family values or culture values. When studying the process of becoming an adult, it is important to focus on understanding the terms "becoming" and "developing". As is known, in the domestic literature of the last century the concept of "becoming" was used in the context of the concept of "development" and is usually identified with the latter. At the same time, modern

\footnotetext{
${ }^{6}$ Yadov V.A. On Dispositional Regulation of Social Behavior of Individual // methodological problems of social psychology M.: Nauka 1975. - Pp. 89-105.

${ }^{7}$ Usnadze D.N. Psychological Research. - M.: Nauka, 1969. - 213 p.
} 
psychological science offers a terminology in which a large thesaurus of concepts in the category of "development", among which the leading place is the term becoming. Author ${ }^{8}$ (L. Romanyuk, 2014) substantiate the essence and correlation of these concepts. The latter refers to the spontaneous variability of things and phenomena, their continuous transition (transgression), transformation into others. This concept appears as the "first truth" (G. Hegel). Thus, becoming is the transition of opportunity into reality in the development process. Its main feature is that the existence of the phenomenon has already begun, but has not yet taken shape. It acts as a process of originating opportunities and turning one into reality. Proceeding from this, the becoming of personality values means a continuous transition, the transformation of those values that acquire in the mind of an young adult person of a meaningful level and continue to integrate into its value system at the level of consciousness. At the same time, values are reconstructed, gaining significance for the human being, hierarchized, embracing new meanings and structured in new ways human living spaces.

Despite numerous studies of nature and mechanisms of values and mechanisms as interdisciplinary problems in psychology there are practically no studies of psychological bases of becoming of values and sense of unity of their content and dynamic representations in higher education. There were particularly thorough studies of values of humanities students as future professionals, teachers, professors, and athletes. However, studies of the becoming of values and meaning (sense) involving students of economy, agriculture, technical and psychological professions were not conducted in universities.

The author's continuous work in schools of business and finance, agricultural technologies, mechanization and electrification, department of biotechnology and veterinary medicine, and the department of psychology and social rehabilitation has identified the specific interest and identified the problem of the current research.

The purpose of this paper is an attempt to uncover ways and mechanisms of becoming of values of students of the departments of accounting and auditing, management of organizations, and psychology.

\footnotetext{
${ }^{8}$ Romanyuk L.V. Psychology of personality values' becoming. Manuscript. The thesis for obtaining of the Doctor's degree in psychological science, specialty 19.00.07. - Educational and Developmental Psychology. Taras Shevchenko National University of Kyiv, Kyiv, 2014. - P. 57-70.

${ }^{9}$ Hegel H.V.F. Philosophy of History / / Works - M.-L., 1935. - T. 8. - P. 8-132.
} 


\section{Development of the Workshop}

In this study, the author used methods of psychological training in the process of influence on students' values development. It incorporated methods and techniques of neuro-linguistic programming (NLP).

The program was to create conditions for changing language strategies of students. Ideally, it is facilitating of the transition of negative values to positive ones, making possible the valuable reorientation of consciousness and behavior. But the mechanism of transition is quite complicated. Therefore, we introduced the future psychologists, accountants, and managers to the common basics of values becoming techniques. It was designed as the human variant of neuro-linguistic programming (NLP) of R. Bendler ${ }^{10}$ and J. Grunder using elements of non-violent communication of the M. Rosenberg and the practical psychology course of 40 NLP training exercises by R. Johnson ${ }^{11}$ (R. Johnson, 2001). Unlike NLP programs that are targeted at fast changes of individuals with mental difficulties and violations, the proposed technique is not designated to influence through unconscious, but to gradually (rather slowly) develop the meaningful awareness of personal values. The program is designed as follows.

Each student had to master two kinds of knowledge about oneself: knowledge-description and knowledge as control of one's activities. The former is the result of applying diagnostics, which allows to obtain a wide range of knowledge of the student's identity. Obtaining such knowledge about oneself allows to compare oneself with others, to formulate questions aimed at further self-discovery, explanation of certain facts of one's own behavior.

Another type of knowledge is acquired by analyzing the activities that students manage. During this analysis, hidden mental constructions that govern behavior are understood. Acquiring this knowledge (selfawareness) helps to purposefully adjust the student's understanding of the world and change behavior without external influences. In fact, this is selfcontrol taught to students through pedagogical support.

NLP is a modeling process and a toolset to intensify the psychological mechanisms of development and change. It is believed that it helps achieve resource condition, which seems to allow to achieve the necessary results. NLP allows to influence the state, opening up new behavior patterns. It is

\footnotetext{
${ }^{10}$ Bendler R. Magic in actions. Meta Publications,U.S.; New edition (1 Jun. 1992). 228 p.

${ }^{11}$ Johnson R. 1940 NLP Training Exercises. Moscow: Publishing "+ PCB, 2001. 384 pp.
} 
defined as "a set of techniques, models and strategies that help successful communication, growth, personality changes and learning"12 (Revell J., Norman S., 1997, p. 14). NLP techniques are intended to set up a rapport (the central concept of this technique), that creates harmonious relations between the participants of communication and interaction of such relations that allow to program the most favorable responses to speech or actions by participants of communication, this interaction provides complete understanding and mutual empathy and helps avoid or quickly correct any adverse situation and avoid misunderstanding in communication.

It is used in teaching as a means of establishing contact between teachers and students, i.e. as a means of harmonizing relationships, goals, intentions, ideas, opinions of all the participants in the learning process. Such harmonization provides for convergence of their emotional perception of reality and learning to respond to this reality, offering a psychological climate for optimal learning and obtaining the best results. With the help of NLP techniques the teacher influences the nonspecific psychic reactivity of those who learn by creating a favorable psychological climate and using nonspecific factors in the classroom behavior and communication - voice, intonation, certain ways of submitting ideas, suggestions etc. This is perhaps the most valuable characteristic of the NLP method, which makes it so effective for training, including the study of psychology.

Four exercises have been designed to clarify the hierarchy of values and their impact on the development for the practical courses. The exercises are suited to different learning styles. In the beginning, a teacher introduces the principles through handouts and demonstrates skills for the participant to see and hear even before they practice them. Most of the exercises were done in groups of three students. The third participant in the group was usually a facilitator. He oversees the progress of the group, and directly supports the participants and supervises exercises. Observation constitutes an essential part of learning and helps develop observation and hearing skills.

Our task was limited to control of each group; intervention was made when a group veered off the set course. This is easily achieved if all the groups which perform the exercise are working in one room provided there

\footnotetext{
${ }^{12}$ Revell J., Norman S. In Your Hands. NLP in ELT. - London: Saffire Press, 1997. - 144 p.
} 
is enough space not to interfere with each other. It is recommended that small group do exercises without using tables.

A wrap-up discussion takes place following practical training to facilitate reflection. Under certain conditions, a certain time for self reflection was also found useful. Observation of demonstrations, doing exercises and reviews in the form of discussion gives more variety to the methods of value formation. The first exercise allows to clarify the participants' hierarchy of values, and the second one reveals their orientations and values, and the third one aims to form the ability to use personal values in business relations or problem solving situations, and the fourth one facilitates recognition of other people's values.

The purpose of training is announced in the introduction, i.e. what the student participants can achieve by doing exercises, and the necessary resources are provided.

The basic principles underlying the lessons are supported by examples the teacher uses in his/her presentation and a detailed plan of exercises. Teaching method support of the exercise provides for review questions asked during the review discussion.

Values in the three spheres of human activity are developed in the course of research 1) communication within the inner circle (family, friends), 2 business (professional), 3) one's own self (emotions, feelings).

During the first stage of training the aim is to provide teaching support for students in identifying values and use them to control themselves and others, encouraging others and themselves to act; the students are challenged to learn and help others to learn to formulate purposes taking into account the most significant things of an individual, i.e. basic values.

An interview method was useful in finding correspondence between studying, future work, objectives, and relationships with others or a situation on one hand, and student's values on the other.

Motivation was to clarify the students' preferences in their personal life, studying, future job or career, and use of this information to encourage oneself to action.

The groups could choose the type work: whether it concerned communication and relations within the inner circle (family, friends), activity (professional), imaginary future self (I-concept), or leisure activities. The exercise contained questions about what would force them to leave any situation. Sometimes the students experienced discomfort 
when discussing such situations. But the researcher stressed that the real and important topics were raised in order to allow students to explore the values important to them. Since the question, what can result in a decision to change a job or terminate relations, allows to reveal oneself and understand others. All of this makes the NLP method adapted by the author to the student audience and the current times.

Each student had an opportunity to answer the following questions: What was the correlation of the students' values? What was similar and what was different? How can these values influence person's choice? How could this knowledge help influence, motivate and manage? As a result of the first exercises, a hierarchy of values was built for the above mentioned three areas of students' activities. To better adapt the NLP method to our student audience, self-assessment methodology was added to the handouts enabling the students to manifest values of higher and lower levels.

The purpose of the second stage was to teach participants to use questions that can discover and discuss the values underlying human actions and aspirations, in particular, to build a bridge between what's important for him/her and organizations which he /she would manage. Exercises at this stage were limited to identification of their values. Interviews revealed what satisfaction students seek to find in the learning process and future activities. The discussions were directed at identifying the values that underlie the partner's positions for each one to explore alternative ways of achieving them.

This method of the exercises aimed to familiarize the participants with the questions which help identify values. In particular this one: "What is important for you in...?"; "What should motivate you...?"; "What makes you...?"; "What forces you...?" The necessity of clarifying the meaning of values by means of questions and hints was stressed. For instance: "What exactly do you mean by...?", or "What exactly would you do... in this situation?". For example, both partners, whose role was played by the students, appreciated honesty. And yet between them there was an argument because one of them considers wages to be fair if they meet needs, while the other believes that payment should be relevant to the effort made. Analyzing the concept of "justice", the students formulated questions to clarify each of the participants' viewpoints. A wrap-up discussion helped to clarify certain changes in the minds of the participating students which took place in the process of activization of the above said psychological mechanisms. 
Similar to the first stage of the experiment, each participant had an opportunity to present to the audience his/her answer to the question: What values were disclosed? What was the difference in the meanings ascribed by various participants to the same values? To what extent did the students' values correspond to their perceptions and how could they achieve greater compliance?

Changes have been traced through the method of value orientation (D. Leontyev, 1992) adapted by us to our student audience ${ }^{13}$.

The purpose of the third exercise was to teach participants to listen to both sides during a dispute, to identify a collision of values, to help the parties clarify the cause of this collision and, if possible, find compromise solutions of the problems.

At this stage the participants were acquainted with the basics of conflict management by clarifying their personal values, and the students came to realize that conflicts arise mainly because of the inconsistencies between orientations and values. For example, if a person is focused on the end result and pays attention to the minutest detail, then he finds it difficult to work with a colleague who focuses on creativity, generates new projects, and skips details. The problem is almost impossible to solve during negotiations without intermediary questions that lead to convergence of values through harmonization of denotations and connotations. As a result, both sides from the above example (let's call one of them 'pedantic', and the other 'proactive') agree with the following: before the "proactive person's" project starts, the "pedant" advises to adopt a plan that will provide for another meeting to resolve all minor issues, before the "pedant's" project starts the "proactive person" helps, offering new ideas. At the end they usually agree on the time needed to try a new style of collaboration.

The fourth exercise was designed to teach participants to recognize values of others based on their nonverbal behavior. At the beginning of this exercise the participants were acquainted with the basics of selection of clues for values of other people. It was specifically admitted that sometimes students may skip talking about the values that influence their behavior, but their non-verbal response is the major clue to their attitude to what is valued by others. The relationship between value orientation and nonverbal behavior is revealed through a number of examples of

\footnotetext{
${ }^{13}$ Leontyev D.A. Methods of Studying Value Orientations. - M.: Meaning, 1992. - 64 pp.
} 
management practices and knowledge of "Psychology of Communication" and "Determination of a Personality Type" test. Students made notes of the identified non-verbal reactions.

The review was aimed to activate the reflection mechanism of the students participating in the class, and it consisted in their answers to the following questions: How many participants were able to successfully implement an imaginary object? What helped them succeed? What interested them most in the values of their peers? How could they apply this idea to influence their peers? Thus, one was able to specify a hierarchy of values of the students- participants, disclose and discuss the values that underlie their human aspirations and actions, identify causes of the collision of values and, whenever possible, find mutually acceptable solutions to problems, train the participants in identifying the participants' values based on their nonverbal reactions.

\section{Method, Results, Discussion and Conclusion \\ Method}

During the research of the psychological mechanisms of students' value becoming, it was established how the experiment impacts specific changes in the ranking of values resulting from the NLP training technology.

To detect the changes in the values of students during training sessions, multivariate disperse analysis was conducted. It's purpose was to check the hypothesis regarding the significance of the main effects of the factors and their statistical interdependence. A dependent variable was the rank of values as suggested by M. Rokeach ${ }^{14,15,16}$ (V.A. Yadov, 1979; Rokeach M., 1972; Rokeach M., 1973). The Institute (major) and gender were the independent variables (factors) in our experiment; dependent variable being the psychological impact on the development of the students' values. The specificity of the latter factor, compared with the former, is that a change of the dependent variable was analyzed for the same students before and after the exposure. Since this factor is "intrapersonal", in this case we deal with the interconnected student samples.

\footnotetext{
${ }^{14}$ Selfrealization and Prediction of Individual's Social Behavior / ed. V.A. Yadov. - L.: Nauka. Leningrad Branch, 1979. - 264 pp.

${ }^{15}$ Rokeach M. Beliefs, Attitudes and Values. - San Francisco: Josey-Bass Co, 1972. - 214 p.

${ }^{16}$ Rokeach M. The nature of human values. - New York : Free Press, 1973.
} 
The variance analysis allows us to break the dependent variable into components, each of which is influenced by a level of the relevant factors, independent action, or rather, by a joint action of several factors.

Thus, several variables were used to test the working hypotheses concerning differences in average ranking of values: 1) for students of various departments; 2) between male and female groups of students; 3) students representing different genders and departments; 4) between the first testing of values during the pilot study and the second - following the training. The author also checked the hypothesis as to the effects of training on the changes in average ranking of values with reference to students' majors (department); gender; gender and department combination was also tested.

Each of the hypotheses listed above was based on the assumption that there were no significant differences in the changes of the dependent variable under the influence of independent variables (factors). In other words, zero hypothesis was taken as a basis. If the F-criterion associated with each hypothesis turned out to be high enough for the probability of its random appearance in accordance with just zero hypothesis to be low enough $(\alpha<0,05)$, then the null hypothesis was rejected and its opposite (alternative) was accepted, which claims that some averages are not equal to each other. The conclusion that some differences led to rejection of the null hypothesis was made on the basis of the analysis of the tables of average values of dependent variables and statistical graphs of interdependence of factors. When interpreting the results of the factor analysis, only the significant figures were taken into account with $p<0,05$. The criterion for assessment of the impact on the attributes (values) of the factors regulated in the experiment was Fisher's F-criterion, i.e. criterion for assessment of the impact of symptom factors regulated in the experiment ${ }^{17}$ (Burlachuk L.F., Morozov S.M, 1989 , p. 48). In our interpretation, we proceeded from the highest meaningful value $(\mathrm{p}<0,05)$ of the F-ratio to the lowest meaningful value.

\footnotetext{
${ }^{17}$ Бурлачук Л.Ф. Словарь-справочник по психодиагностике / Л.Ф. Бурлачук. С.М. Морозов - Киев : Наукова думка, 1989, p. 48.
} 


\section{Results}

In particular, the highest F-ratio $(F=13,085$ at $p=0,001)$ in the study was scored by "Erudition" of the I-values which changed under the direct influence of the training irrespective of the gender and specialty (faculty, institute) factors. The latter two indicated the trends of changes that occurred under the influence of the former (Table 1.).

According to the gender factor we received the average ranking for male students after training $\mathrm{M}=4,85$, with $\mathrm{m}=0,63$ (before training $M=9.79$, with $m=0,75)$, and for female students the average rank $M=6$, 51 , with $\mathrm{m}=0,80$ (before training $\mathrm{M}=10.70$, with $\mathrm{m}=0,95$ ).

According to the specialty (faculty, institute) factor we obtained the following results of the change of orientation towards development: male students majoring in business management changed their orientation in relation to education and development in the course of comprehension and influence of the researcher from average ranking $M=9,29(\mathrm{~m}=1,76)$ to $-M=6,29(\mathrm{~m}=1,48)$, (difference $M=6)$, and female students in this area of education - from $M=10,70(\mathrm{~m}=1,47)$ to $-\mathrm{M}=6,20(\mathrm{~m}=1.24)$ (the difference being $M=4,50$ ). Students majoring in audit and accounting changed their attitude in favor of the need to develop work constantly to improve physically and mentally from the mean rank $M=9,43(\mathrm{~m}=1,25)$ to $-M=5,29(m=1.05)$ (difference $M=4,14)$, students of psychology from $M=8,20(\mathrm{~m}=2,08)$ to $-\mathrm{M}=4,80(\mathrm{~m}=1,75)$, (the difference being $M=3,4)$. Another significant change in the rank of values due to the training impact was T-value "Empathy" $\mathrm{F}=13,364$ at $\mathrm{p}=0.000$. Differential effects by gender were manifest in $M=9,33$ (at $\mathrm{m}=0,76$ ) prior to the researcher's influence and $\mathrm{M}=6.20$ (at $\mathrm{m}=0,70)$ following it male students $(\mathrm{M}$ difference $=3.13$ ) and $\mathrm{M}=11.14$ (when $\mathrm{m}=0,95)-$ prior to the training and $\mathrm{M}=6.56$ (at $\mathrm{m}=0,88$ ) - following it for female students $(M$ difference $=4.58)$.

For T-values significant changes of values' rank during trening's experimental impact was T-value "Cognition" $\mathrm{F}=31,125$ at $\mathrm{p}=0,000$. Differential gender effects were manifested in $\mathrm{M}=9.33$ (at $\mathrm{m}=0.76$ ) before the effect of training and $M=6.20$ (at $\mathrm{m}=0.70$ ) after it in male students (difference $\mathrm{M}=3.13$ ), and $\mathrm{M}=11.14$ (at $\mathrm{m}=0.95$ ) - before training and $\mathrm{M}=6.56$ (at $\mathrm{m}=0.88$ ) - after it in female students (difference $\mathrm{M}=4.58)$. 
Table 1

Direction of changes of values-means in different student groups formed by combinations of department and gender and intrapersonal factors of a researcher's influence

\begin{tabular}{|c|c|c|c|c|c|c|c|c|}
\hline \multirow{3}{*}{ I-values } & \multicolumn{8}{|c|}{$\begin{array}{c}\text { Intrapersonal Influence } \\
\text { Within-Subjects Contrasts }\end{array}$} \\
\hline & \multicolumn{2}{|c|}{$\begin{array}{c}\text { influence } \\
\mathrm{V}\end{array}$} & \multicolumn{2}{|c|}{$\begin{array}{l}\text { influence } \\
\text { V }\end{array}$} & \multicolumn{2}{|c|}{$\begin{array}{c}\text { influence } \\
\mathrm{V}\end{array}$} & \multicolumn{2}{|c|}{$\begin{array}{c}\text { influence } \\
\text { V }\end{array}$} \\
\hline & $\mathrm{F}$ & Sig $p$ & $\mathrm{~F}$ & Sig $p$ & $\mathrm{~F}$ & Sig $p$ & $\mathrm{~F}$ & Sig $\mathrm{p}$ \\
\hline $\begin{array}{l}\text { Neatness } \\
\text { (cleanliness) v19 }\end{array}$ & ,001 & ,969 & ,961 & ,458 & 5,416 & ,023 & 2,016 & , 102 \\
\hline $\begin{array}{l}\text { Good manners } \\
\text { v20 }\end{array}$ & ,842 &, 362 & 1,782 & ,115 & ,078 & ,781 &, 557 & 695 \\
\hline $\begin{array}{l}\text { High } \\
\text { aspirations v21 }\end{array}$ & 9,680 & ,003 & 1,494 & 193 & ,984 &, 325 & ,287 & 885 \\
\hline Cheerfulness v22 & 8,972 & ,004 & 1,605 & ,159 & 10,57 & ,002 & 1,689 & , 162 \\
\hline Diligence v23 & 1,383 & ,244 & 1,748 &, 123 &, 252 & 617 &, 250 & ,909 \\
\hline Independence v24 & 4,642 &, 035 & 2,427 &, 034 & 089 & ,767 & ,434 & ,783 \\
\hline $\begin{array}{l}\text { Intolerance to } \\
\text { faults v25 }\end{array}$ & ,673 & ,415 & ,815 &, 562 &, 007 & ,934 & ,442 & ,778 \\
\hline Education v26 & $\begin{array}{c}13,08 \\
5\end{array}$ & ,001 & 2,629 & ,023 & ,087 & ,769 & 1,747 & , 149 \\
\hline $\begin{array}{l}\text { Responsibility } \\
\text { v27 }\end{array}$ & ,054 & ,817 & 1,888 & ,095 &, 300 &, 586 & ,898 & ,470 \\
\hline Rationalism v28 & 1,820 & ,182 & 1,775 &, 117 & ,399 &, 530 & 1,093 & ,367 \\
\hline Self-control 29 & ,086 &, 770 & 2,313 & ,043 & 5,919 & ,018 & 4,961 & 001 \\
\hline $\begin{array}{l}\text { Courage in } \\
\text { defending one's } \\
\text { point } v 30\end{array}$ & 4,794 & ,032 & 4,316 & ,001 & 1,952 & , 167 & 4,502 & ,003 \\
\hline Strong will v31 & 2,663 & ,107 & ,493 & ,811 & 3,820 &, 055 & 4,198 & ,004 \\
\hline Tolerance v32 & 7,011 &, 010 & 3,664 &, 003 & 7,781 & ,007 & 2,838 &, 031 \\
\hline Honesty v33 & 2,187 &, 144 & 1,338 &, 252 & 1,565 &, 215 &, 438 & ,781 \\
\hline Sensibility v34 & $\begin{array}{c}13,36 \\
4\end{array}$ & ,000 & 1,250 & ,292 & 053 & ,819 & ,338 & ,851 \\
\hline $\begin{array}{l}\text { Width } \\
\text { of views v35 }\end{array}$ & ,321 &, 573 & ,326 & ,921 & ,191 & ,663 & 1,356 & ,258 \\
\hline $\begin{array}{l}\text { Good } \\
\text { performance v36 }\end{array}$ & 3,926 & ,051 & ,592 & ,736 & 2,338 & ,131 &, 764 &, 552 \\
\hline
\end{tabular}




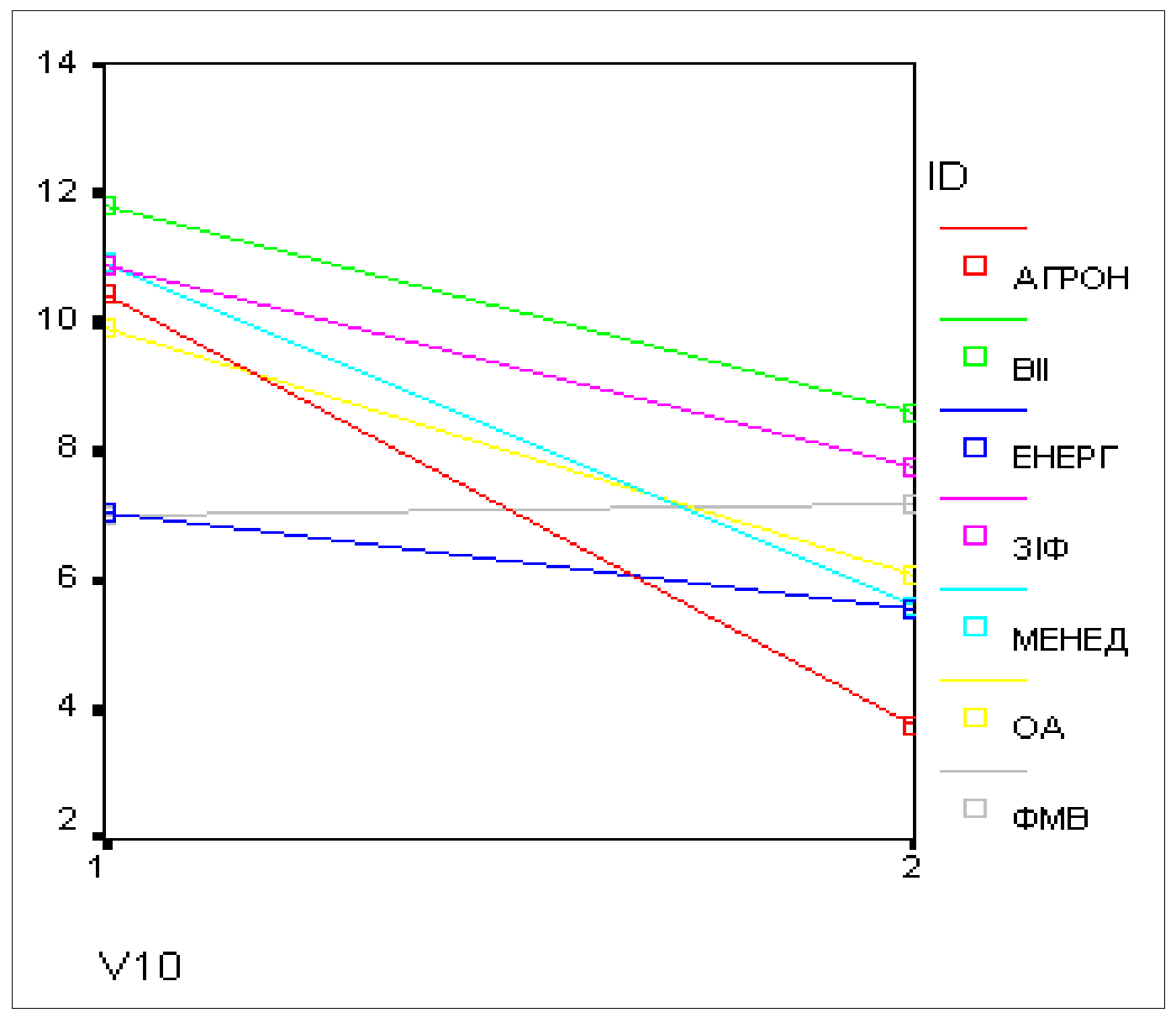

Fig. 1. Differential effects of changing the rank of the T-value "Cognition" in the process of training for faculty factor

The differential effects of changing the rank of the T-value "Cognition" in the course of training in a specialty (faculty, institute) can be observed in Fig. 1. The directions of significant changes in the ranks of the T-value "Cognition" in students of different faculties, whose representatives participated in the developmental experiment, are traced here. In particular, students in the specialty "Management of Organizations" significantly changed their attitude to the value of "Cognition" from the average rank $\mathrm{M}=10.00(\mathrm{~m}=1.77)$ to $-\mathrm{M}=4.57$ $(\mathrm{m}=1.64)$, (difference $\mathrm{M}=5.43$ ), and female students - from $\mathrm{M}=11.60$ $(\mathrm{m}=1.49)$ to $-\mathrm{M}=6.30(\mathrm{~m}=1.37)$, (difference $\mathrm{M}=5.30)$; students in the specialty "Accounting and Auditing" - from $\mathrm{M}=9,67(\mathrm{~m}=2,70)$ to $M=7,00(\mathrm{~m}=2,50)$, (difference $\mathrm{M}=1,67)$ and female students - from $\mathrm{M}=10.00 \quad(\mathrm{~m}=1.77)$ to $\mathrm{M}=5.71 \quad(\mathrm{~m}=1.64)$, (difference $\mathrm{M}=4.29)$; students of the Institute of Agrotechnology - from $M=8,86(\mathrm{~m}=1,77)$ 
to $-\mathrm{M}=3,43(\mathrm{~m}=1,64)$, (difference $\mathrm{M}=5,43)$ and female students from $M=16,00(\mathrm{~m}=3.31)$ to $\mathrm{M}=5.00(\mathrm{~m}=3.07)$, (difference $=11.00)$; students of the Faculty of Veterinary Medicine - from $\mathrm{M}=8,43(\mathrm{~m}=1,77)$ to $-M=8,71(m=1,64)$, (difference $M=-0,28)$ and female students from $M=6,09(m=1.41)$ to $M=6.18(m=1.31)$, (difference $M=-0.09$ ); students of the Zoo Engineering Faculty - from $M=9.50(\mathrm{~m}=2.34)$ to $\mathrm{M}=5.50(\mathrm{~m}=2.17)$, (difference $\mathrm{M}=4.00)$ and female students - from $\mathrm{M}=12.00(\mathrm{~m}=2.09)$ to $\mathrm{M}=9.60(\mathrm{~m}=1.94)$, (difference $=2.40)$.

Students of the specialty "Energy in agricultural production" of the Institute of Mechanization and Electrification change their attitude in favor of the need to know (constantly work on themselves, expanding their education, outlook, general culture, intellectual development) from the middle rank $\mathrm{M}=7.07(\mathrm{~m}=1,25)$ to $-\mathrm{M}=5.57(\mathrm{~m}=1.16)$ (difference $\mathrm{M}=1.50)$ and cadets of the Military Engineering Institute - from $\mathrm{M}=11.80(\mathrm{~m}=2.09)$ to $-\mathrm{M}=8,60(\mathrm{~m}=1.94)$, (difference $\mathrm{M}=3.20)$.

A detailed analysis indicates significant changes in the orientation to development and cognition in the training process (the difference between grades before and after training ranges from 3-5).

As a result of participating in a developmental experiment, there was an increase in developmental orientation and cognition with some differences in the middle ranks, which depended on the interaction between the gender and the faculty where the student studied. Thus, students in the specialty "Organization Management" rank T-value "Development" has moved up 6 ranks, and in students - by 4,50; students in the specialty "Accounting and Auditing" changed their attitude towards it within 8 ranks above, and female students - respectively 4,29; students of the Institute of Agrotechnology also have an increase in the rank of this value by 8.85 , and in students - by 8.5 units; students of the Faculty of Animal Engineering make the choice in favor of development in the process of training and the difference is -6.50 , and the students of this faculty - 2.20; among the students of the Faculty of Veterinary Medicine the difference between the ranks is the lowest - 0.71, and in the students 1.46; at students of institute of mechanization and electrification - 4.14; cadets of the Military Engineering Institute - 3.4.

Thus, there is a significant increase in the rank of T-values "Development" and "Cognition" in students of all specialties, faculties and institutes who voluntarily participated in the developmental experiment 
and observed some differential effects resulting from the interaction of independent factors of gender and faculties.

The multivariate analysis of variance shows that in the course of the training there were significant changes in students' values, and practically all working hypotheses were confirmed.

\section{CONCLUSIONS}

In the process of training, intra-personal and socio-psychological mechanisms of values' becoming significantly intensified; especially interest, self assessment, and reflection. Multivariate analysis of variance was conducted to actually confirms all the working hypotheses and conclude that introduction of training preparation into the educational process enhances the influence of socio-psychological mechanisms and promotes activation of the intrapersonal mechanisms of value development of students (10 indicators of changes in average rank T-values and eight indicators of I-values proved to be reliable). Virtual increase in the rank of T-values "Development " and "Cognition" was observed in all the students who volunteered for the experiment and certain variable effects arising from the interaction of independent factors of gender and major were observed. Significant changes that took place in the students' values among the values of "Development" and "Cognition", and among values-means of "Education" and "Sensibility" result from the fact that during training these values were the most specified to meet the requirements of the training subject.

The use of methods developed by M. Rosenberg and R. Bendler, J.Grunder allowed the subjects of the educational process to change to a better relationship style, introduce a powerful element of self-control into these relationships. Having mastered a particular language, one not only begins to speak in a different way, he starts to see events in a different light, or to understand and respond differently (even internally!). Thus, a change of language and learning strategies, as well as self-control orientation activate one's psychological mechanisms of values, when construction of changes in the style of communication is a change in consciousness and behavior patterns and values help the subject of the educational process to develop understanding of the phenomena and ability to develop the spiritual side of one's personality.

Our future researches on development of students' values include investigation of interaction and mutual influence of intra-personal and sociopsychological mechanisms on their development, which is highly important for practical management, training technology and education of students. 


\section{SUMMARY}

The paper describes ways, mechanisms and their effects in the personalities' values becoming in educational process, defines the methodology of pedagogical influencing by interactive teaching methods using psychotechnology, also describes the technology of personalities' values becoming. Using factor analysis, author traces directions values' changes in various groups of students by specialization, gender, and a researcher's influence. The training contributed to a significant activation of all intra-personal and socio-psychological effects and mechanisms of values becomingn. The conducted multivariate analysis of variance actually confirmed all the working hypotheses and concluded that the introduction of training in the educational process increases the influence of social and psychological mechanisms and promotes the intensification of intrinsic mechanisms of students' values becoming (reliable I-values). A significant increase in the rank of T-values of Development and Cognition was observed in all students who voluntarily participated in the experiment, and observed some differential effects resulting from the interaction of independent factors of gender and specialty. Significant changes that occurred in the values of students among the values-goals of "Development" and "Cognition", and among the values-means "Education" and "Sensibility" are the consequence that in the training process these values are maximized by the requirements for the subject educational activities.

\section{REFERENCES}

1.Бурлачук Л.Ф. Словарь-справочник по психодиагностике / Л.Ф. Бурлачук. С.М. Морозов - Киев : Наукова думка, 1989, p. 48.

2. Bendler R. Magic in actions / R. Bendler. Meta Publications, U.S.; New edition (1 Jun. 1992). 228 p.

3. Bolotov V.A. Development of Professional Pedagogical Education / V.A. Bolotov, V.I. Slobodchykov / Pedagogy. - 1997. - № 4. - Pp. 66-68. Hartmann N. Ethics / N. Hartmann. - M., 1958.

4. Hegel H.V.F. Philosophy of History / H.V.F. Hegel / Works M.-L., 1935. - T. 8. - Pp. 8-132.

5. Husserl E. Philosophy, as Strict Science / E. Husserl. - M.: Logos, 1911, vol. 1.

6. Johnson R. 1940 NLP Training Exercises. - Moscow: Publishing “+ PCB, 2001. - 384 p. 
7. Zymbardo F., M. Liayppe Social Impact / R. Johnson - Ed.: Peter, 2001. $-448 \mathrm{pp}$.

8. Leontyev D.A. Methods of Studying Value Orientations / D.A. Leontyev. - M.: Meaning, 1992. -64 p.

9. Parygin B.D. Fundamentals of Socio-Psychological Theory / B.D. Parygin. - M: Thought, 1971. Dictionary of Psychology - Moscow: Politizdat, 1990. - $494 \mathrm{p}$.

10. Romanyuk L.V. Psychology of personality values' becoming / L.V. Romanyuk. Manuscript. The thesis for obtaining of the Doctor's degree in psychological science, specialty 19.00.07. - Educational and Developmental Psychology. - Taras Shevchenko National University of Kyiv, Kyiv, 2014. - Pp. 57-70.

11. Revell J. In Your Hands. NLP in ELT / J. Revell, S. Norman. London: Saffire Press, 1997. - 144 p.

12. Rokeach M. Beliefs, Attitudes and Values / M. Rokeach. - San Francisco: Josey-Bass Co, 1972. - $214 \mathrm{p}$.

13. Rokeach M. The nature of human values / M. Rokeach. - New York : Free Press, 1973.

14. Romenets V.A. History of Psychology of the Twentieth Century / V.A. Romenets I.P. Manokha / Introduction by V.A. Tatenko, T.N. Titarenko. - K.: Lybid, 1998. - 992 p.

15. Reference Dictionary of Psychological Diagnosis / Burlachuk L.F., Morozov S.M.; Ed. in Chief Krymskiy S.B. - Kiev: Science. Dumka, 1989. $-200 \mathrm{p}$.

16. Self-realization and Prediction of Individual's Social Behavior / ed. V.A. Yadov. - L.: Nauka. Leningrad Branch, 1979. - 264 p. Usnadze D.N. Psychological Research / D.N. Usnadze. - M.: Nauka, 1969. $-213 \mathrm{p}$.

17. Yadov V.A. On Dispositional Regulation of Social Behavior of Individual / V.A. Yadov // Methodological problems of social psychology M.: Nauka 1975. - Pp. 89-105.

\section{Information about the author: Romanyuk L. V. Dr., Professor,}

V. I. Vernadsky Taurida National University 33, Ivana Kydri str., Kyiv, 01042, Ukraine 


\section{PSYCHOLOGICAL AND PEDAGOGICAL IMPACT ON THE DEVELOPMENT OF MODERN CHILDREN'S CREATIVE ABILITIES}

\section{Vynohradova V. Ye.}

\section{INTRODUCTION}

Today, the progress of society is aimed not only at the development of technological and technical industries, but also at the development of personality throughout life. The gains in many areas of the state depend on the creativity and creativeness of the people living in it. Accordingly, the problem of creativity, training and education of the creative person and the stimulation of creative work is important in public policy. The experience and successes of the most developed countries in the field of science, manufacturing, new technologies, culture and education indicate the need for a radical restructuring of the system of training and education in the direction of creating conditions for a creative person to freely express his abilities, development in accordance with the makings.

The psychological basis of educational projects and programs for the development of a competitive personality is the principle of selfdevelopment. It integrates the system of principles of personality development formulated in the theory of the origin and formation of the psychics and consciousness of L.S. Vygotskyi, the psychological theory of personality and activity of A.N. Leontyev and S.L. Rubinstein, and the theory of the development of the child's personality L.I. Bozhovych, D.B. Elkonin and others.

In our opinion, a person's awareness of his or her potential opportunities, the prospect of personal and professional growth encourages him or her to a constant experimenting, that is, to creativity.

The consequences of the socio-economic crisis that our state is experiencing is that society today is no longer an institution for the formation of a full-fledged personality, and the family is in a situation of conflict and struggle for existence. In this regard, the need to ensure conditions for the full development of the personality of a child, his abilities, optimal education and training is highlighted. In particular, the 
urgent problem now is the development of creativity, creative abilities, adaptation to new and stressful social conditions through the use of one's own psychological resources.

In the conditions when traditional moral and ethical imperatives are destroyed and new ones are not created, when society does not give social guarantees to a young citizen, a personality is formed with internal conflict, aggressive, incapable of sympathy and empathy, devoid of a sense of duty and responsibility.

Recently, more and more information has appeared about children who are a significant problem for parents and public educational institutions. Their behavior contains non-traditional forms of interaction with parents, teachers and educators. That is, the problem of generations both existed and exists today. This phenomenon was called the theory of generations. In our opinion, attention should be paid to the issues of transformation of old approaches in the educational process. So, now, there arises the question of determining the contradictions that arise between representatives of different generations that are participants of educational processes. And also the question of finding out methods and forms of training that can be effective for new generations comes to the fore.

\section{The impact of generational change on creating new approaches in the education system}

For some time now, teachers, psychologists, philosophers, sociologists and others have been solving the problem of finding new approaches in the educational process for the new generation. Despite the fact that the younger generation has been the subject of psychological and pedagogical research since the end of the 19th century, a question of the phenomenon of the theory of generations remains very relevant today. Fundamental are the approaches of L.S. Vygotskyi, J. Piaget, B.G. Ananyev, G.S. Kostyuk, M.I. Lysyna, A.A. Lublinska, A.V. Zaporozhets, L.A. Wenger, P.Ya. Halperin ${ }^{1}$. The theory of generations in 1991 was created by American scientists N. Hove and V. Strauss. Their study showed that the main difference between generations is their value system. Today, this issue in Ukraine is mainly dealt with by sociologists. O. Borusevvch believes that the study of a "generation" as a sociological category can help

\footnotetext{
1 Методики исследования базовых характеристик участников современного образовательного процесса / М.Р. Мирошкина [и др.]. М., 2015. 95 с., С. 11.
} 
to find ways for the restoration and development of the Ukrainian cultural ethos $^{2}$. These are the directions of its search "through the formation of a scientifically based concept of the intergeneration transmission of traditions", that A. Gorban and I. Kalnoy deal with ${ }^{3}$. And A. Svynarenko stresses the need to implement the Ukrainian ethnos in state policy, management, business and other spheres of life of the Ukrainians ${ }^{4}$.

As for psychologists and teachers, then, unfortunately, there are only occasional studies on finding approaches to the development and training of generation $\mathrm{Y}$ and $\mathrm{Z}$. However, the millennium generation has already grown. These are children who are now between 15 and 36 years old. And the education system is just beginning certain reforms. Some of the teachers who taught back in the days of the Soviet Union were not able to adapt to new conditions and adapt to the generations of children who grew up in the independent Ukraine. From time to time, you can hear from students or parents of students about the authoritarian style of teaching, careful presentation of lectures and literal learning of memory. That is, it is about forming a conformal personality that cannot hold its own position. Therefore, the education and training system that has been in use for several generations is not effective enough today and new approaches to the development of the younger generation should be sought. It should also be noted that the theory of generations today is widely used by psychologists, marketers, sociologists, pedagogues, economists, and managers. After all, having determined the main differences between generations, one can find a universal approach to representatives of all ages. Today of those people living on the planet, six generations are distinguished: generations of winners or GI (born in 1901-1922); silent generation (1923-1942); generations of boomers or baby boomers (1943-1963); generation X (1963-1983); generation Y (1983-2003); generation Z (2003-2023). The main thesis of this theory is the fact that the period of time in which a person was born affects his or her worldview and value system ${ }^{5}$. A person who reaches a certain age does not acquire the

\footnotetext{
${ }^{2}$ Борусевич, О. (2000) Міжпоколіннева трансформація етнічних цінностей : автореф. дис. на здобуття наук. ступеня канд. соц. наук : спец. 22.00 .03 «соціальна структура, соціальні інститути» (р. 15). Київ.

${ }^{3}$ Горбань, А, \& Кальной, И (Eds.). (2012). Поколения в истории: ритмы духовности (p. 440). Симферополь: ИТ «АРИАЛ».

${ }^{4}$ Свинаренко А. (2004) Міжпоколінні особливості колективних ідентифікацій в умовах інтенсивних соціальних змін : автореф. дис. на здобуття наук. ступеня канд. соц. наук : спец. 22.00.03 «соціальна структура та соціальні відносини» (р. 16). Київ.

5 Лумпиева Т.П., Волков А.Ф. Поколение Z: психологические особенности современных студентов. URL: http://ea.donntu.org:8080/handle/123456789/21748.
} 
age values characteristic of this period. This is due to the fact that children who reach the age of their parents do not become the same as they are; their attitude to life is still different ${ }^{6}$. That is, N. Hove and V. Strauss substantiated that every twenty years a new generation appears with a different value system and behavior different from their predecessors. According to the scientists, the dominant influence on the formation of generational values is the parenting model, which is adopted in the family, as well as factors such as political, economic, social and technological events that occurred with children under 11-12 years old ${ }^{7}$. These are the values which influence a person's behavior throughout his or her life attitude to work, views on the world, consumer behavior, and the like . $^{8}$

Today, based on an analysis of modern sources, certain trends can be identified in the formation of psychological characteristics of adolescents belonging to the $\mathrm{Z}$ generation'. It should be noted that scientists observe changes in the age development of the nervous system of the young generation due to the digital revolution. So, the psychophysiological development of each child is subject to the laws of consistent age development, each stage of which prepares him or her for the successful passage of the next one. The flow of information that a modern schoolchild, who is not adapted for children's consciousness, has to consume, provokes increased excitability, sensitivity, restlessness, fussiness and, in extreme cases, hyperactivity. An increase in the number of children diagnosed with ADHD and hyperactivity is observed. At the same time, representatives of the $\mathrm{Z}$ generation learn quickly and also quickly process information, can instantly switch from one type of activity to another, and also act in multitasking conditions. Possession of information and the possibility of its search contributes to the formation of the young people's self-confidence, confidence in their abilities, and forms their own point of view. There is an increase in the number of children diagnosed with ADHD and hyperactivity ${ }^{10}$.

\footnotetext{
6 Зайцева Н.А. Теория поколений: мы разные или одинаковые? // Российские регионы: взгляд в будущее. 2015. № 2 (3). С. 220-236.

Арцимович И.В. Современное поколение: вызовы обществу или времени // Интерактивная наука. 2017. № 12. С. 119-121; Антипов А. Времена года и времена жизни // Russian Valley. URL: http://rugenerations.su/2009/04/30/времена-года-и-времена-жизни; Ожиганова Е.М. Теория поколений Н. Хоува и В. Штрауса. Возможности практического применения // Бизнес-образование в экономике знаний. 2015. № 1. С. 94-97.

8 Зайцева Н.А. Теория поколений: мы разные или одинаковые? // Российские регионы: взгляд в будущее. 2015. № 2 (3). С. 220-236.

${ }_{9}^{9}$ Сапа А.В. Поколение Z - поколение эпохи ФГОС // Продуктивная педагогика. 2015. № 8 (56). С. $2-9$.

${ }^{10}$ Сапа А.В. Поколение Z - поколение эпохи ФГОС // Продуктивная педагогика. 2015. № 8 (56). С. 2-9.
} 
It should be noted that researchers distinguish the following characteristic, the so-called clip-like thinking. This means the ability to perceive the world through short vivid images and messages, for example, through a news feed, short articles, or short video clips ${ }^{11}$.

Practice shows that the average period of concentration of attention of a representative of generation $\mathrm{Z}$ at one object is only eight seconds. In addition, representatives of the $Z$ generation want to see icons, emoticons, pictures replacing text instead of the text ${ }^{12}$.

This state of affairs explains why it is difficult for modern youth to read multivolume works of fiction by classics that have been read by older generations, and thesial literature (checklists, Life hack, step-by-step algorithms, diaries, comics) is a success. The representatives of the $\mathrm{Z}$ generation are growing up in a world in which opportunities have no boundaries, and the time resource is limited. Thus, young people adapted to the need to evaluate and filter vast amounts of information very quickly. The perception and thinking of "digital children" has not become positive or negative, it has changed and acquired a new format which satisfies the needs of the information era of humanity. They differ in the fact that from birth, not yet learning how to speak, they can switch on a computer, tablet or mobile phone to play their favorite game. That is, the $\mathrm{Z}$ generation are children who are influenced by the Internet and modern technologies. They are not used to spending much time with peers in the playground; they are more formed alone with technologies. That is, more and more they are interested in the virtual, not the real world. Quite often they do not know how to work in a team, due to poorly developed communication skills.

Scientists also note that the relationships between parents and children of the $\mathrm{Z}$ generation are friendly, as a rule, there is no authoritarian pressure from parents. The absence of a desire to build a career is observed in the majority of children of this generation. They are not afraid of the world, are rather freedom-loving, like to travel, a part of them like to learn, quickly absorb large amounts of new information. It is clear that they get most of the information from electronic resources. However, as a rule, this knowledge is not deep, but is superficial. However, scientists note that they

\footnotetext{
${ }^{11}$ Азаренок Н.В. Клиповое сознание и его влияние на психологию человека в современном мире // Мат. Всерос. юбилейной науч. конф., посв. 120-летию со дня рождения С.Л. Рубинштейна «Психология человека в современном мире». Том 5 «Личность и группа в условиях социальных изменений» / отв. ред. А.Л. Журавлев. М.: Изд-во «Институт психологии РАН», 2009. С. 110-112.

1230 фактов о современной молодежи: исследование Сбербанка и Validata // Янгспейс. 2017. № 11. Режим доступа: http://youngspace.ru/faq/sberbank-issledovanie-molodezhi.
} 
are interested in complex tasks; they are distinguished by creativity and the ability to solve several problems simultaneously.

However, $\mathrm{Z}$ children generation should to be motivated. They expect quick feedback on their actions. It should be noted that X-parents are not satisfied with the ineffective programs of their children's development and their paternity. Therefore, they are actively involved in the process of developing new programs that meet their requirements, and searching for alternatives in the development of their children. The huge number of startups in the field of education over the past 25 years is clear evidence of this. If 27 years ago private kindergartens and schools did not exist in Ukraine, today in Ukraine we have about 350 private kindergartens and 142 private schools. This suggests that the old principles of education and training do not satisfy the request of modern parents and their children. And the demand is restrained only due to the fact that a large number of parents cannot afford a private kindergarten or school due to the high cost of educational services.

E. Shamis connects the value of childhood with the fact that the $\mathrm{X}$ generation had a real, free, eventful childhood. Therefore, childhood is perceived by the $\mathrm{X}$ generation as the mega-important period of life. That is why its representatives are trying with great responsibility to give the best childhood to their children. In addition, they compensate for the occupation of their parents - baby boomers, who were constantly at work in their childhood. Given the conditions for the $\mathrm{Z}$ generation to be raised by $\mathrm{X}$-parents, we can say that, on the one hand, Z-children grow up in a friendly and trusting atmosphere. They know that their parents will do everything possible for them to be happy, they can share their successes or problems, and they themselves participate in important family issues. Young people respect parents, assimilates family values, knows how to build relationships, they become internally freer, conscious, able to reflect and have a more developed emotional intelligence. On the other hand, X-parents' hyper guardianship affects the formation of a consumer attitude to society and the environment, egocentrism and infantilism in children of the $\mathrm{Z}$ generation. It can be noted that the modern generation are trying to make friends with their parents and this will favorably affect personality development and future formation.

One of the theses of the theory of generations should be noted. It testifies that a thing which is in short supply becomes a value ${ }^{13}$.

${ }_{13}$ Антипов А. Времена года и времена жизни // Russian Valley. URL: http://rugenerations.su/2009/ 04/30/времена-года-и-времена-жизни. 
Accordingly, the $\mathrm{Z}$ generation, immersed in virtual communication, which is fragmented and ignores any spiritual connection between people, lacks live communication, interpersonal direct communication. Spiritual communication becomes the value of the modern youth, hence the desire to be on friendly relations within the family, as well as the value and significance of the family in the whole. Therefore, it is possible to determine a tendency which characterizes modern adolescents: live today, have fun and do work that brings pleasure, joy and a good income, but does not take much time ${ }^{14}$. Young people are not oriented to a long-term professional career, an eight-hour working day and a desire to be a workaholic. The $\mathrm{Z}$ generation live in an endless and rapidly changing flow of information, surrounded by social networks and advertising, calling and cultivating lives on the principle of "here and now". Perhaps that is why modern children think about the nearest future, live live for today and do not think about distant prospects.

In the continuation of the analysis of the leading characteristics of modern children, we pay attention to another important aspect of the theory of generations - cyclicity. That is, the generations that follow each other, for example, $\mathrm{X}$ and $\mathrm{Y}$ generations, have different values and attitudes from each other, but the generations of "great-grandfathers" find their reflection in the generation of "great-grandchildren." The generational cycle is theoretically about 80 years. Based on this, the previous incarnation of $\mathrm{Z}$ is the "silent generation", or "book children", born between 1923 and 1943. The "silent generation" was formed under the conditions of the dangerous Stalinist post-war world. Therefore, they spent their childhood with books, moving away from reality into a completely different ideal art world. We are witnessing a similar situation now. The $\mathrm{Z}$ generation lives in the face of overcoming the deep economic crisis, military events in eastern Ukraine, the annexation of the Crimea, the possible expectation of terrorist acts, in the face of growing information about crime, accidents, and epidemics. They, like the "great-grandfathers" generations, are looking for the opportunity to feel full-fledged free personalities. The world of virtual reality satisfies this need, for modern children it becomes more natural and understandable ${ }^{15}$.

\footnotetext{
1430 фактов о современной молодежи: исследование Сбербанка и Validata // Янгспейс. 2017. № 11. Режим доступа: http://youngspace.ru/faq/sberbank-issledovanie-molodezhi.

15 Чумаков В. По материалам беседы с Е. Шамис и А. Антиповым // Коммерческий директор. 2007. № 11 (23). C. 56-61.
} 
Today, the Internet plays a significant role in the life of the modern youth. It forms views, lifestyle, interests, replaces television, teaches and enables online communication and the like. Children and adolescents are better versed in technology than in human emotions and behavior. According to the doctor of psychological sciences, the candidate of medical sciences psychotherapist M. Sandomyrskyi, if the person-toperson communication had a great influence on a person of previous generations, then for the new generation, most likely, virtual communication will prevail over the real one. He notes that modern young people tend to communicate less with each other, but at the same time they communicate more. They communicate less in social reality and more and more in virtual reality. This tendency, according to the scientist, leads to the autization of the "generation of the future." It should be noted that in autism the author does not understand personality disorder, but its preclinical forms. In this context, autization acts as a way of interacting with the world of people, immersed in themselves from childhood and able to communicate with others, as protection from the problems of a modern lifestyle, as a way to isolate oneself from the world ${ }^{16}$.

Z. Bauman notes that responsibility for modern youth takes on a shortterm, instrumental nature. Representatives of the $\mathrm{Z}$ generation prefer to avoid responsibility or minimize its share both in degree and in time ${ }^{17}$. So, according to N. Zorka, the youth makes a choice in favor of a well-paid job, but not associated with high responsibility ${ }^{18}$. Considering that responsibility implies independence in decision making and choice, then, according to N.N. Zarubina, young people "have an increased tendency to undue risk and underestimation of the possibilities of negative consequences against the background of the prospects for the entry of momentary benefits - pleasure, benefits, and high appreciation from others. Also for the $\mathrm{Z}$ generation, instrumental values are categories such as education and professionalism. This means that the process of qualitatively obtaining knowledge, skills and abilities among the youth is inferior to its result - passing exams and obtaining a diploma, but the profession itself is not of interest and is considered by them as a resource

\footnotetext{
16 Чумаков В. По материалам беседы с Е. Шамис и А. Антиповым // Коммерческий директор. 2007. № 11 (23). С. 56-61.

17 Бауман 3. Текучая современность / пер. с англ.; под ред. Ю.В. Асочакова. СПб.: Питер, 2008. 240 с.

18 Зоркая Н. Современная молодежь: к проблеме «дефектной» социализации // Вестник общественного мнения. 2008. № 4 (96). С. 17-19.
} 
for future success, as a tool that allows you to take "a highly profitable economic niche".

So, an analysis of the values of the $\mathrm{Z}$ generation allows us to identify some trends in the formation of the views of the modern youth. However, these conclusions are enough to understand the difference in the views of older generations and the representatives of $\mathrm{Z}$. For modern youth, the traditional patterns that are provided by older generations can no longer serve as unequivocal guidelines in decision-making on issues of principle $^{19}$. Therefore, it is necessary to develop new approaches and methods of training, development and education in accordance with the needs of modern youth.

\section{Search for innovative psychological and pedagogical approaches for the development of the $Z$ generation children"s creative abilities}

For modern researchers from different scientific fields an important task arises in studying "digital children" and tracking their formation in the future. However, many educators still do not know about the phenomenon of the Z generation. Some use it only as a "tag": it is a "heavy" child. And the question of how to teach, educate and develop this child is more often solved on an intuitive level. Therefore, it is necessary to determine what innovative methods need to be developed so that children who have new psychological characteristics and behaviors to be effective for their development. We are especially interested in the direction of development of creative abilities of talented youth.

If the information on the psychological characteristics of children of the $\mathrm{Z}$ generation and their behavior has recently been significantly disseminated, the question of an effective system of education and training in modern psychological and pedagogical science remains unaddressed. Of course, in order to create a new model of the educational process in higher education or to transform the old one, it is necessary to find out the needs of modern youth and determine the peculiarities of their value system.

However, an analysis of the problem of interaction and training of generations showed that, in the presence of certain approaches to the study of this problem, at the same time, there was a lack of a holistic, systematic

\footnotetext{
19 Сычев А. Поколение Z: те, кто будет после: интервью с Марком Сандомирским. URL: http://hrportal.ru/article/pokolenie-z-te-kto-budet-posle.
} 
scientific and pedagogical understanding of the interaction of different generations as carriers of experience, a certain system of values, means of communication and assimilation of knowledge in the modern educational space. Recently, only some Russian pedagogues have been studying this issue: M.R. Miroshkin, S.B. Tsimbalenko and A.V. Reshetnikova. The issues of intergenerational interaction in the search for new psychological and pedagogical approaches require in-depth research in domestic science.

We conducted a pilot study of the values of first-year students of Taurida National V.I. Vernadsky University. According to the results of the study, it was revealed that students of the "digital generation" have gender differences in the value system. Male students prefer values such as: life wisdom, health, social recognition, the happiness of others, creativity, self-confidence; the girls chose: a happy family life, self-confidence and a materially secured life. The values to which they do not attach importance at all are as follows: cheerfulness, independence, amount of education, honesty, a flexible attitude to shortcomings in oneself and others, rationalism and tidiness.

Regarding the attitude towards creative realization and creativity in general, the position of students was the following. For first-year male students, "creativity" is: human activity aimed at creating something new, completely unique product; development of creativity, creative abilities; human talent, freedom of opinion and favorite activity; this is a unique worldview; activities aimed at expressing oneself, one's thoughts and emotions; this is life itself; an activity which a person enjoys and which he or she performs voluntarily. For female students, "creativity" is: the ability to express their feelings and emotions; Liberty; expression of personality through art; activities aimed at uniqueness and implementation of ideas and creativity; the ability to see beauty; an opportunity to prove oneself; complete freedom of action; sublimation; expression of emotions through anything.

The source of inspiration for the guys is free time, peace and quietness, good weather, a loved person, playing sports and intrinsic motivation to achieve a goal, that is, a search for strength in oneself; free time, support for loved ones, praise. Motivation for creativity for girls can be: the world, the beauty of nature, people around, music, movies, silence, books, dancing, long journeys, communication, the success of others, support of close people; desire to develop, interesting people, beautiful things, love. 
Analyzing the obtained results, we can conclude that freshmen understand creativity as a process of creating a completely new unique product; activities in which a person can express himself; art and talent display; activities that you enjoy. The motivation for this activity is the support of close people, communication, the beauty of nature, the environment and love.

As we can see, the understanding of the concept of creativity and motivation for creativity in boys and girls are similar.

So, based on students' requests, we can develop certain provisions and recommendations for the development of creative abilities of a new generation of personality in the educational process of the university.

Let's define some characteristics of the process of education and training of "digital children".

1. Defining the limits of permitted behavior, the teacher should create conditions for the student to apply a creative approach: allow themselves to establish the "rules of the game" and plan their behavior.

2. To communicate with students as well as adults, showing respect and sincere interest, listen to them, perceive them as wise people who know unknown things.

3. To give detailed instructions and explanations, as well as provide the right to express their opinion in the process of making independent decisions and making conscious choices.

4. Raising the children of the $\mathrm{Z}$ generation is at the same time hard work and privilege: they have a lot to teach, they know a lot not only about themselves, but also about adults, they feel wiles and react negatively to them.

5. In order to be effective, pedagogy must be genuine, professional, full of love. Only such pedagogy is perceived by children of the $\mathrm{Z}$ generation.

6. It should be noted that discipline is extremely important and vital for the $\mathrm{Z}$ generation, since they are creative and mobile in nature, they constantly experiment with different things and experience the limits of what is permitted. Sometimes this behavior can be dangerous, but strict prohibitions do not work with them.

The generation $\mathrm{Z}$ discipline should be based on the development of their spiritual interests, given the following recommendations:

- discuss with the student the behavior that is not clear to you and make sure that he or she has made the right conclusions; 
- react to any situation immediately, avoid dictating tone;

- always keep your promises, accompany the slightest misunderstanding with simple explanations.

Romanyuk L.V. notes that today part of the teachers of Ukrainian universities use active teaching methods, form an atmosphere of dialogue, freedom and creativity at classes. That is, "having mastered the appropriate design algorithm, teachers themselves successfully develop new game techniques and other pedagogical tools that purposefully affect the process of developing a subjective attitude to values among students and pupils of the corresponding age" 20 .

The essence of the implementation of the formation of values and meaning lies in the creation by higher education institutions of conditions for the purpose of self-knowledge, self-development and self-improvement of students' personalities, as well as for self-study, understanding and formation by students of value-semantic foundations of both their personality, their social roles, and future professional activities ${ }^{21}$.

However, far not every existing pedagogical system can provide such conditions for the upbringing and development of the $\mathrm{Z}$ generation children. Most authors agree that education should be alternative and among the most acceptable pedagogical systems they call the Monessori school, Waldorf and other progressive systems. However, they do not have a continuation at a higher school. And, a young man who studied according to an alternative system of education still falls into the standard conditions of universities. Therefore, it may be difficult for him to adapt to a standard learning system and be creative in reproductive learning conditions.

Thus, the above examples of psychological and pedagogical interaction suggest the search for other types, technologies and teaching methods of the younger generation. In our opinion, it is appropriate to turn to a participatory approach. That is, in the educational space this is based on the subject - subjective learning: on the one hand, participants of the educational process, both from teachers, the administration, and students, are objects for transformation and development, and on the other, they are subjects of self-development and self-realization ${ }^{22}$.

\footnotetext{
${ }^{20}$ Романюк Л.В. Становлення цінностей особистості: концептуальна модель та їі методологічний потенціал // Психологія особистості. - Івано-Франківськ. - 2013. - С. 138-148.

21 Романюк Л.В. Становлення цінностей особистості: концептуальна модель та ії методологічний потенціал // Психологія особистості. - Івано-Франківськ. - 2013. - С. 138-148.

22 Мирошкина М.Р. Педагогический потенциал самоорганизации // Сибирский педагогический журнал. - 2014. - № 3. - С. 14-21.
} 
However, the problem of teaching creativity, preparing for professional creative activity is unusual. How to teach something that you yourself don't know, that is, new, creative. From here the idea of "free" education, "spontaneous" development of creativity has arisen. So, it is impossible to teach creativity directly, in the usual sense of the word "learning". We offer the application of an innovative teaching method the group facilitation method.

The founders in the development of facilitation technology as a special process, increase the effectiveness of the group and each individual, are psychologists such as Marvin Weisbord, Ron Lippit, E. SchindlerReinman, Eric Trist, Fred Emery and others. They considered facilitation as an expanded system of flexible impacts on the personality, aimed at the formation of creativity. The methods for finding new solutions are divided into group and individual. Among the group ones, one should note the "brain-storming" of F. Osborne, the synectic of J. Gordon, creative discussion and the like. The socio-psychological aspect of the organization of a creative group has a fundamental role in group methods of searching for new solutions. Among individual or combined methods, one can note the generalized heuristic method of O.M. Polovinkina, the method of garlands of associations, or metaphors, the "seven-time search method" of G.Ya. Bush, the method of "morphological analysis" of F. Zwicky.

Facilitation, as a rule, contains a combination of many methods, however, they are not always focused on a specific result, the main thing in their application is an impetus to creativity. At the classes devoted to the development of creativity, it is necessary, first of all, to create a free playing atmosphere aimed at ensuring comfortable communication, selfconfidence, creative potential of one's own and of the group members. This method is based on such important values as participation, responsibility, teamwork, creativity and the like. The most important principle laid down in it is the empowerment of participants. The basic principles of group facilitation are: participation, group work and cooperation, individual creativity, consensus, reflection, action orientation.

The main goal of facilitation is to increase group efficiency. From the point of view of the result, this helps the group to become better, namely: to improve the quality of decisions, improve team relations, increase personal satisfaction of the group members, and promote the development of creativity and creative abilities of each student. 
The advantages of facilitation are that in working with students their productivity is enhanced. Firstly, this method helps to create a productive working environment and free oneself from formalities, go beyond the ordinary and expand thinking, that is, stimulate creativity: the generation of ideas and practical solutions. Secondly, it allows you to more effectively organize the discussion process and improve the quality of the results. The participants have an understanding that the work results belong to them. In our opinion, this method can be used in such types of educational activities as conducting seminars, trainings and conferences.

We started using the facilitation method at Taurida National V.I.Vernadsky University. It helps to create an atmosphere of free learning and development during the seminar. During facilitation, one can observe how students analyze and realize the need to develop professional qualities, the acquisition of knowledge and skills that they lack. Thanks to this teaching method, the student does not only actively participate in the discussion of seminar issues, but also independently chooses the areas of deepening the knowledge that is interesting and necessary for further professional development. That is, he has the opportunity to build a personal plan for training and development. However, the personal influence of the teacher-facilitator at the lesson is minimal. He sets the format of work, but does not control the process, as during a regular lesson, he gives each student the opportunity to prove himself in accordance with his abilities, capabilities and desires.

The results of such work can be discussed and adjusted at seminars and individual consultations. In order for all the links in controlling the process of developing creative activity of students to work as a whole, an integrated approach to the formation of a creative specialist is necessary. At this the effectiveness and efficiency of pedagogical implementation is ensured by the entire logic of constructing the content of the educational process, the style of training and education, and relevant organizational forms and techniques.

The situation of promoting self-development and self-training (facilitative accompaniment) of a student will turn into facilitating the development of a collective or group subject, is eco-facilitation. Within its framework, access to a collective subject is never open only to one of the subjects of collective interaction; it is possible only as a result of joint coordinated activities to achieve comparable or common goals. 
Another of the psychological and pedagogical approaches corresponds to the principle of environmental friendliness. That is, the main task of the teacher is to create a personality-oriented educational reality. There is enough scientific, pedagogical and psychological literature about a personality-oriented approach. However, in our opinion, its essence may lie in the fact that to obtain knowledge a student can not only develop and acquire knowledge in accordance with his motivation and level of knowledge, but also independently build his own path of development and formation in the profession. So, taking into account the capabilities of the Internet and other modern forms of education, a teacher can accompany the development of a student's personality in accordance with his requests and capabilities. A new everyday life appears, within the framework of which a person can not only draw up unique educational strategies for him, but also form a unique set of professional competencies and qualifications. So, the student is the subject of the educational process, and teachers accompany this process. At the same time, in collaboration with students, a personality-oriented retraining and advanced training of the teaching staff take place.

This regard, a number of characteristics are included in the environmental friendliness criterion of pedagogical actions:

- the well-known principle of "do no harm", which we are used to perceive with regard to doctors and psychologists, today must be correlated with the specific situation of the pedagogical impact, as well as of the one to whom it is directed. First of all, we are talking not only about a combination of external influences, but also about the internal psychological characteristics of a teacher who makes a pedagogical or psychological decision.

- the principle of development - the pedagogical action should take into account the fact that in the process of change and development the teacher also changes, therefore ecological is the action that is social in nature and manifests itself not only, for example, in personal tolerance, but also in the ability to tolerate a situation of uncertainty as part of the educational space.

- pedagogical management, in contrast to the traditional accompaniment of an individual, is transformed into a facilitative process of activating the capabilities of the entire study group as the main subject, 
it is an ecofacilitative accompaniment or ecological systemic help in the self-development of educational ecosystems which are self-developing.

- nonlinearity of ecological pedagogical management who are extremely sensitive to random moments of self-organization of educational ecosystems: the learning effect obtained spontaneously can significantly change the overall strategy of professional or other training (the wellknown "butterfly effect"). Hence the sensitivity to such spontaneous transitions acts as an ecological and tolerant of uncertainty action.

- the principle of self-organization of participants in the educational process in the face of uncertainty and risks of the modern world.

- the principle of actualization of the future: in the face of global uncertainty of the future, the student must be prepared to form and implement his own life project, and not follow the logic of the instructions of the older generation. That is, today a young person needs to have an image of this future, to understand the path to achieving it and to be able to self-organize in order to pass a certain route effectively.

- the principle of correspondence of the content of pedagogical activity to the main characteristics of the generation of children emerges from the basic contradiction of modern pedagogy and the special characteristics of the modern generation of children.

It is also necessary to note that the $\mathrm{Z}$ children should be constantly motivated for each task due to the fact that they do not like to work for the future result. They can be involved in teamwork in a co-working environment. In order to get the best result from their work, it is necessary to give them creative tasks which are maximally interesting for the $\mathrm{Z}$ children themselves. In addition, make sure that they really consider their activities useful to others.

In the future, the research results will allow correlating the values of different generations, to which teachers and students belong. Also, in our opinion, it is necessary to find out ways of gaining knowledge by new generations, which sources are used to obtain information. It is very important to find out common values of different generations and their main differences. So, how educational process in Ukraine should change.

\section{CONCLUSIONS}

Having summarized and analyzed the materials of recent years on the study of the modern $\mathrm{Z}$ generation, it should be noted that this topic is of 
great interest from scientists of different fields: pedagogy, psychology, marketing, philosophy, management, economics and the like. Studies on this issue are underway. They are diverse, multidimensional, which consider the various characteristics of lifestyle and values. It should be noted that the values of the oldest $\mathrm{Z}$ generation representatives are still in the process of formation due to the fact that they have not reached adolescence yet. Z. However, in a year or two, they will become students and teachers will need to look for new approaches and teaching technologies. Therefore, it is necessary to conduct a deeper and more massive study of the generation, which will allow us to complement the socio-psychological characteristics of the $\mathrm{Z}$ generation.

Along with this, a unified theoretical and methodological base has been formed for studying the modern generation, there is a lack of field research, which are provided by current demands of secondary and higher education. In particular, the youngest age groups of children and adolescents remain little studied. The psychological and pedagogical methods and techniques of training, development and upbringing of the new generation are not sufficiently developed. Summing up, we can conclude that modern children are a generation that quickly responded to the needs of the time, adapted to new conditions of life. However, the society did not manage to prepare new models, forms, methods and technologies of the educational system. For the present, this issue will be highlighted in further research.

\section{SUMMARY}

The article reveals the theory of generations of American scientists $\mathrm{N}$. Howe and V. Strauss. The most significant factors of the theory of generations that affect the development of personality, the formation of his or her values have been considered and analyzed. It has been established that the main difference between generations is their value system. It is the analysis of the values of the $\mathrm{Z}$ generation that allows us to identify some tendencies in the formation of the views of the modern youth.

The influence of generational change on the creation of new approaches in the system of higher education has been determined. The basic methods and approaches to the educational impact on students of a new generation have been revealed. Important factors of stimulating the development of creative abilities based on the personality-oriented nature 
of the teacher's interaction with students, the use of psychological and pedagogical technologies that ensure students' independent activity in the process of creative activity and the consistency of educational work with students in a creatively developing environment have been described.

A theoretical search for innovative psychological and pedagogical approaches to the development of creative abilities of "digital children" took place in the article. The directions for the development of the student as a person have been provided. The importance of forming the talents of young leaders has also been noted.

\section{REFERENCES}

1. Азаренок Н.В. Клиповое сознание и его влияние на психологию человека в современном мире // Мат. Всерос. юбилейной науч. конф., посв. 120-летию со дня рождения С.Л. Рубинштейна «Психология человека в современном мире». Том 5 «Личность и группа в условиях социальных изменений» / отв. ред. А.Л. Журавлев. М.: Изд-во «Институт психологии РАН», 2009. С. 110-112.

2. Антипов А. Времена года и времена жизни // Russian Valley. URL: http://rugenerations.

3. Арцимович И.В. Современное поколение: вызовы обществу или времени // Интерактивная наука. 2017. № 12. С. 119-121.

4. Бауман 3. Текучая современность / пер. с англ.; под ред. Ю.В. Асочакова. СПб.: Питер, 2008. 240 с.

5. Безрукова С.Б. Психологические особенности современного поколения. URL: https://nsportal.ru/nachalnaya-shkola/materialy-dlyaroditelei/2016/05/23/psihologicheskie-osobennosti-sovremenn ogo Ван ден Берг Дж. Крутые всегда остаются крутыми / Пер. с анг. СПб., 2012.

6. Гаврилова А.В. Социально-психологические особенности ментальности нового поколения // Вестник Удмуртского университета. Серия «Философия, психология, педагогика». 2016. Т. 26. Вып. 2. С. 58-63.

7. Дудорова Л. Фасилитация корпоративных мероприятий // Корпоративная культура. - 2009. - № 5.

8. Зайцева Н.А. Теория поколений: мы разные или одинаковые? // Российские регионы: взгляд в будущее. 2015. № 2 (3). С. 220-236. 
9. Зоркая Н. Современная молодежь: к проблеме «дефектной» социализации // Вестник общественного мнения. 2008. № 4 (96). C. $17-19$.

10. Кондакова Н.А. Младшее поколение как социальнодемографическая категория: теоретический аспект // Вопросы территориального развития. 2015. Вып. 7 (27). URL: http://vtr.vscc.ac.ru/article/1519/full

11. Лумпиева Т.П., Волков А.Ф. Поколение Z: психологические особенности современных студентов. URL: http:/ea.donntu.org:8080/ handle/123456789/21748

12. Методики исследования базовых характеристик участников современного образовательного процесса / М.Р. Мирошкина [и др.]. M., 2015.95 c.

13. Мирошкина М.Р. Педагогический потенциал самоорганизации // Сибирский педагогический журнал. 2014. № 3. С. 14-21.

14. Мирошкина М.Р. Разные поколения - разный педагогический подход // Школьные технологии. 2014. № 2. С. 8-20.

15. Нечаев Н.Н., Дурнева Е.Е. Цифровое поколение: психологопедагогическое исследование проблемы // Педагогика. 2016. № 1. C. $36-45$.

16. Ожиганова Е.М. Теория поколений Н. Хоува и В. Штрауса. Возможности практического применения // Бизнес-образование в экономике знаний. 2015. № 1. С. 94-97.

17. Пищик В.И. Поколения: социально-психологический анализ ментальности // Социальная психология и общество. 2011. № 2. C. $80-88$.

18. Поколение Selfi e: пять мифов о современной молодежи // ВЦИОМ. Пресс-выпуск № 3265. 13.12.2016. URL: https://wciom.ru/ index.php?id $=236 \&$ uid $=115996$

19. Проект «Новое поколение» Фонда общественного мнения. URL: http://fomgeneration.wordpress.com

20. Решетников О.В. Поколение $\mathrm{Z}$ и недалекое будущее рынка труда // Школьные технологии. М., 2014, № 1.

21. Сапа А.В. Поколение Z - поколение эпохи ФГОС // Продуктивная педагогика. 2015. № 8 (56). С. 2-9. 
22. Сычев А. Поколение Z: те, кто будет после: интервью с Марком Сандомирским. URL: http://hrportal.ru/article/pokolenie-z-tekto-budet-posle/

23. Чумаков В. По материалам беседы с Е. Шамис и А. Антиповым // Коммерческий директор. 2007. № 11 (23). С. 56-61.

24. Шамис Е. «Ослабь хватку» или «Профессиональное родительство» поколения X. URL: https:// rugenerations.su/

25. Шамис Е., Антипов А. Теория поколений. URL: https://www.psycho.ru/library/258.

26. Brooks D. What's the Matter With Kids Today? Not a Thing. The New York Times. Nov. 5. 2000. URL: http://www.nytimes.com/ 2000/11/05/books/what-s-the-matter-with-kids-today-not-a-thing.html (accessed 28.08.2019).

27. Schwarz R. The Skilled Facilitator Approach // The IAF Handbook of Group Facilitation / Ed. by S. Schuman. San Francisco: Jossey-Bass, 2005, P. 21-34.

\section{Information about the author: Vynohradova $V$. Ye. $\operatorname{Dr}(\mathrm{PhD})$, Associate Professor,} Head of the Psychology and Pedagogy Department of the V. I. Vernadsky Taurida National University 33, Ivana Kydri str., Kyiv, 01042, Ukraine 


\section{CONCLUSIONS}

Summarizing the results of scientific research on the personality development psychological problems, it is necessary to stress the diversity of theoretical issues and applied problems which are solved by scientists. The need to study this problem is being actualized under current conditions of changes in the socio-political and economic structure of Ukrainian society which significantly influences the personality development.

In the current conditions of social and political transformation of society there is a need to develop such social institutions that could harmonize the interests of the state as well as people's private values and interests, emphasizing the need to promote the mechanisms of private life autonomy. It has been established that there is a certain connection between the degree of modiness, closeness, priority of the proposed behavior by the educational institution and the characteristics of grouping, interpersonal perception in really functioning groups, which is an important factor in the personality development.

Socio-cultural content has a great influence on how a person experiences traumatic events and emerges from them, how much he or she feels the support of society, has a sense of belonging to community, to what extent social norms and patterns have models for overcoming difficult situations. The kind of progress in the post-traumatic period whether it will be stigmatization, a decrease in the standard of living, reduction, or growth, development, positive changes - will depend on the conditions created in society. It has been proved that post-traumatic growth, as one of the effective mechanisms of personality development, is a natural mechanism for overcoming traumatic events in human life. It is noted that the study of the phenomenon of post-traumatic growth is important for reorienting the direction of psychotherapeutic intervention from "treatment" and helping to creating social mechanisms that would contribute to the opening of new opportunities in the person's life and the renewal of all spheres of his or her life.

The complex socio-economic and political situation in the country is primarily reflected in the functioning of the family, as the most influential and long-lasting institution of socialization and personality development at all stages of his or her development. A large number of families are unable to provide for the proper welfare and upbringing of children without state 
support, so violence against the child is quite common in the Ukrainian family. Violence impedes a child's mental and personal development, affects all levels of personality functioning and causes many problems, both social and psychological. One of the most significant consequences of violence is a decrease in the capacity for expression, lack of trust in people, hostility, hatred of others and the world on the whole.

It has been proved that hatred is not an inborn feeling, but acquired by a person in the course of a lifetime. Hatered as a persistent negative feeling of a subject, is characterized by a constant desire to inflict as much pain or suffering on the object of hatred, is a consequence of domestic violence, a product of the reproduction of that pattern of behavior, of the life experience that the child has gained in the family. Sometimes hatred develops in a person as a result of his or her ideas about the affect of external circumstances on an individual.

The determined problematics points to the need for a state social policy in Ukraine aimed at strengthening the family institution. One of its directions is the implementation of a complex-differentiated approach that takes into account the specifics of the family and the type of domestic violence, and is aimed at providing social and psychological assistance to the child, as well as to doing work with each family member.

Domestic violence against women is often a consequence of gender stereotypes, and the solution to this problem lies in the plane between such spheres of public life as culture, morality and law. Therefore, the problem of domestic violence is closely linked to issues of gender inequality and gender discrimination that are relevant to Ukrainian society. One of the ways to solve this problem is to introduce educational and training courses on gender issues when working with students. This will help young people to understand and feel what positive changes a decrease in the level of discriminatory manifestations brings in it and will make it possible to realize that a person's development, his or her personal growth is impossible without rethinking gender norms and patterns adopted in the environment. This is especially true of gender stereotypes, which very often become an obstacle to the development of personality and achievement of goals that are relevant and significant for him or her. It is emphasized that psychological accompaniment for personality development cannot occur outside of a gender theme, since the gender 
issue accompanies a person throughout his life and is manifested in all areas (social, domestic, economic, political, etc.).

It is emphasized that in the course of the training courses, all intraspecific and socio-psychological mechanisms of formation of personality values, especially interest, self-esteem and reflection, are significantly activated. Change and assimilation of new language strategies, the mindset of self-control activate the psychological mechanisms of values development, when from building a change in the style of communication occurs a change in the style of consciousness and values help the subject of the educational process to develop understanding of the phenomena and capacities for self-development of his or her personality's spiritual part.

In the context of the contemporary Ukrainian society, relevant are the issues of ethnic consciousness and self-awareness that are most adequately explained within the scientific paradigm according to which traditional ethnic culture is the way and the result of group adaptation to new conditions. This statement is scientifically substantiated by the study of ethnopsychogenesis and ethnic consciousness of the Crimean Tatars. The process of formation of national identity is manifested primarily through the revival of national values, symbols, myths, traditions, language, history, which in the complex make up the national cultural heritage, which has a significant impact on the personality's development.

It has been established that personality metaphors have the ability to act as stabilizers of the psycho-emotional state of a person, demonstrating models of effective analogous behavior, which is extremely important for humans as social creatures; they contribute to the transformation of the Personal History, the liberation from harmful, ineffective life scenarios, and the creation of new ones, the opening and realization of new opportunities in life. Thus, metaphorization contributes to the formation of the perceived holistic image of "I-Others-World", creates the conditions for awareness of his person, which, in turn, is an important psychological factor in the development of personality.

The need for further study of the psychological aspect of adult training, namely androgynous support, is noted. In the context of the problem of psychological accompaniment for the personality's professional formation, methodological and substantial guidelines are required to be specified not only for structured understanding of the 
individual's psychological accompaniment, but also for the phased implementation of the research results into real pedagogical practice.

The represented monograph contains the results of theoretical and methodological, applied studies which allow not only to consider the mentioned problem in more detail and in a new way, but also to introduce them into the real process of psychological accompaniment of personality development in the difficult modern conditions of Ukrainian society establishment. 
Publishing house "Liha-Pres"

9 Kastelivka str., Lviv, 79012, Ukraine 44 Lubicka str., Toruń, 87-100, Poland

Printed by the publishing house "Liha-Pres"

Passed for printing: August 30, 2019.

A run of 150 copies. 